\title{
SALTON SEA GEOTHERMAL POWER PILOT PLANT PROGRAM
}

\author{
A TECHNICAL PROPOSAL
}

BY THE

\author{
SOUTHERN CALIFORNIA \\ EDISON COMPANY
}

TO THE

ENERGY RESEARCH AND DEVELOPMENT ADMINISTRATION 


\section{DISCLAIMER}

This report was prepared as an account of work sponsored by an agency of the United States Government. Neither the United States Government nor any agency Thereof, nor any of their employees, makes any warranty, express or implied, or assumes any legal liability or responsibility for the accuracy, completeness, or usefulness of any information, apparatus, product, or process disclosed, or represents that its use would not infringe privately owned rights. Reference herein to any specific commercial product, process, or service by trade name, trademark, manufacturer, or otherwise does not necessarily constitute or imply its endorsement, recommendation, or favoring by the United States Government or any agency thereof. The views and opinions of authors expressed herein do not necessarily state or reflect those of the United States Government or any agency thereof. 


\section{DISCLAIMER}

Portions of this document may be illegible in electronic image products. Images are produced from the best available original document. 


\section{LEGAL NOTICE}

This data shall not be disclosed outside the Government and shall not be duplicated, used, or disclosed in whole or in part for any purpose other than to evaluate the proposal; provided, that if a contract is awarded to this offeror as a result of or in connection with the submission of this data, the Government shall have the right to duplicate, use, or disclose the data to the extent provided in the contract. This restriction does not limit the Government's right to use information contained in the data if it is obtained from another source without restriction. 


\section{CONTENTS}

Page

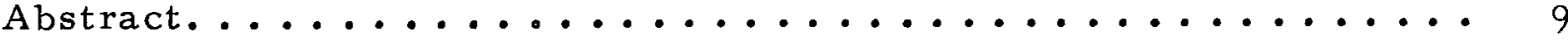

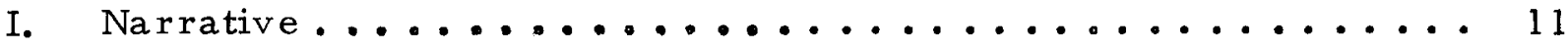

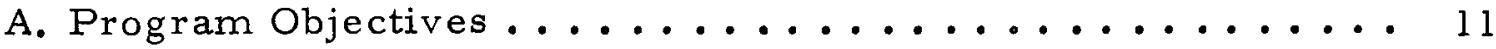

1. Statement of Problem ....................... 11

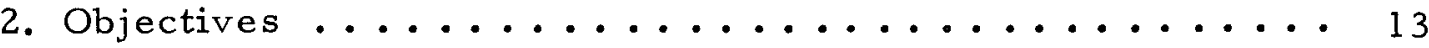

3. Specific Questions to be Answered.............. 14

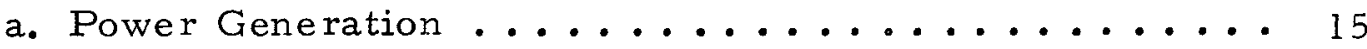

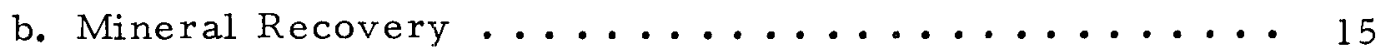

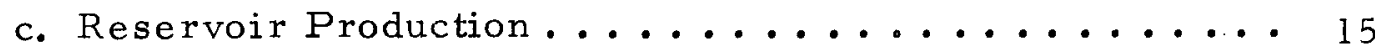

d. Area Resource Test Facility ............... 16

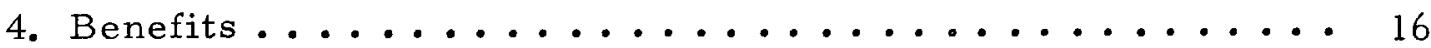

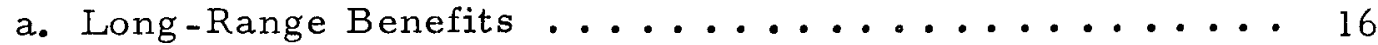

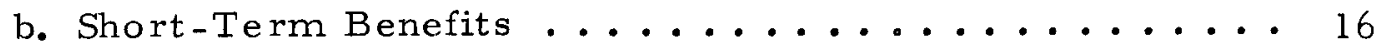

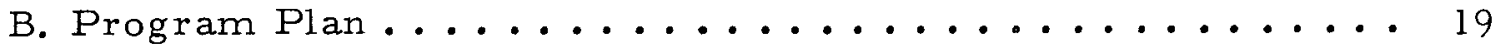

1. Program Accelerating Factors.............. 19

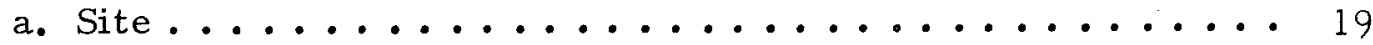

b. Geothermal Brine Properties.............. 21

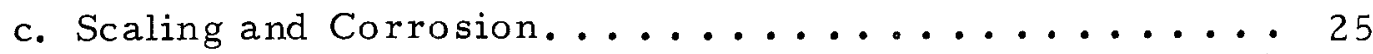

d. Power Cycles ..................... 40

e. Mineral Recovery ................... 45

f. Reservoir Assessment and Production.......... 51

g. Environmental Impact Assessment ........... 52

h. Area Resource Test Facility ............. 53

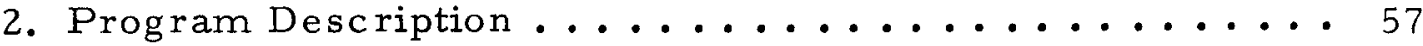

a. Scope and Technical Objectives............ 57

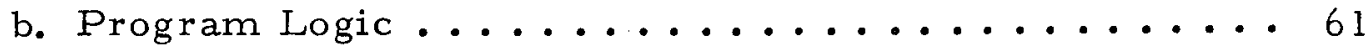

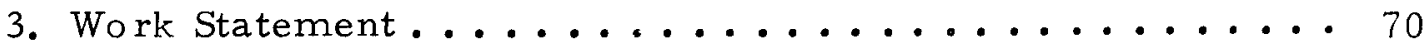

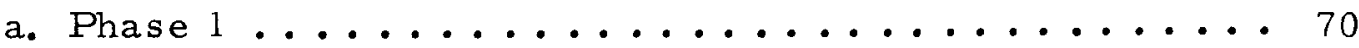

Activity I - Power Generation Subprogram ....... 70

Activity II - Mineral Recovery Subprogram. ....... 80

Activity III - Reservoir Production Subprogram . . . . 82

Activity IV - Area Resource Test Facility . . . . . . 84 


\section{CONTENTS}

Page

Activity $\mathrm{V}$ - Program Management .......... 85

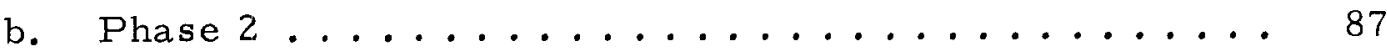

C. Program Organization and Management ............ 89

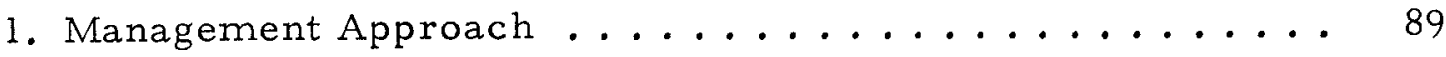

2. Organization and Management Controls .......... 89

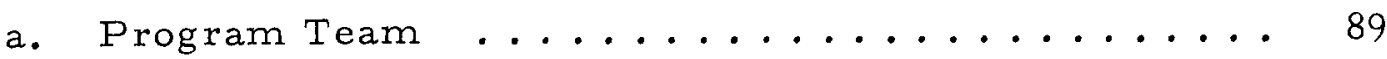

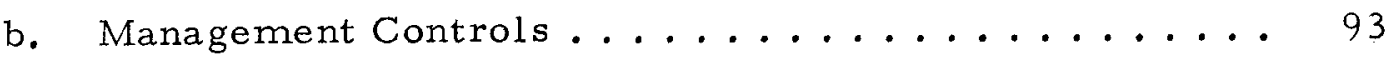

3. Functional Organizations Implementing the Program .... 93

a. Southern California Edison ................ 93

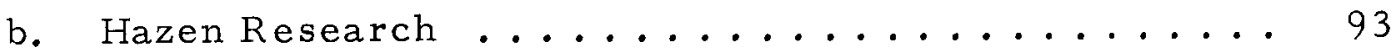

c. Phillips Petroleum Company ............. 95

d. Atomics International Geothermal Program

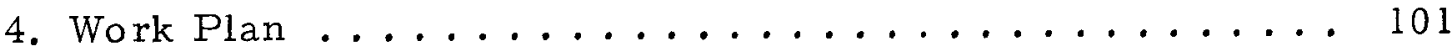

5. Relationship to Existing Arrangement .......... 101

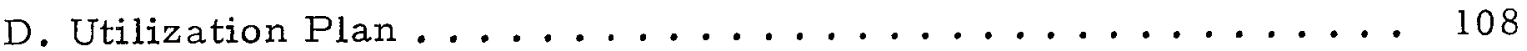

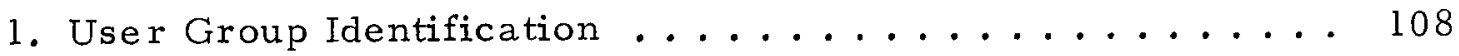

a. Research Directed Toward Pilot Plant ........ 108

b. Area Resource Test Facility ............. 109

2. User Demand Description ........................ 110

3. Utilization Process Description ........................ 11

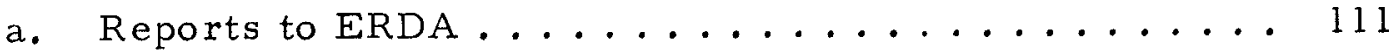

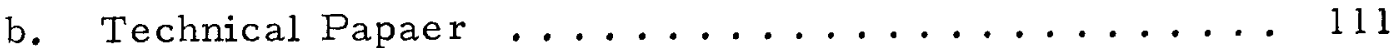

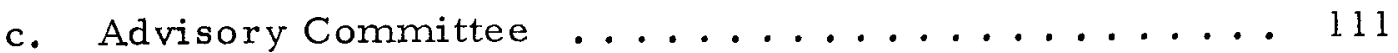

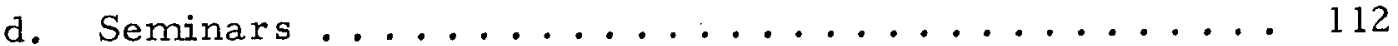

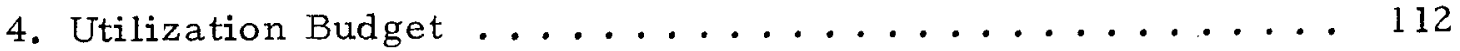

E. Related Programs and Activities of the Organizations ..... 113

1. Southern California Edison Company ........... 113

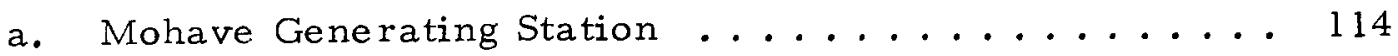

b. San Onofre Nuclear Generating Stations, Units 2 and $3 \ldots \ldots \ldots . \ldots \ldots 114$

c. Kaiparowits Generating Station, Units 1-4 ...... 114

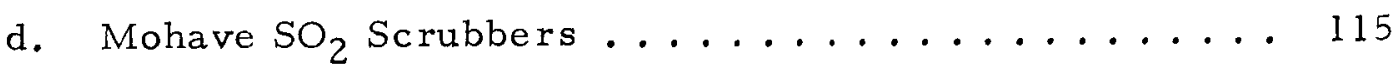




\section{CONTENTS}

Page

2. Atomics International ..................... 115

a. Geothermal Studies ................. 117

b. Saline Water Conversion Programs ........... 118

c. Aqueous Process Programs............... 119

d. Heat Exchangers ..................... 120

e. Organic Working Fluids .............. 120

f. Thermal and Process Analysis Capability ........ 121

g. Manufacturing ................... 122

h. Supporting Facilities ................ 122

i. Regional Laboratory.................. 123

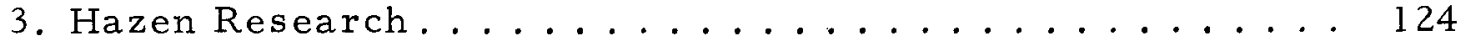

4. Phillips Petroleum Company .............. 125

F. Related Programs in Other Organizations . . . . . . . . 127

G. Educational and Training Component . . . . . . . . . 129

H. Vitae and Bibliographies .................. 130

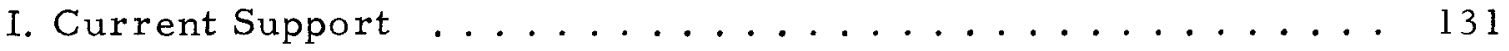

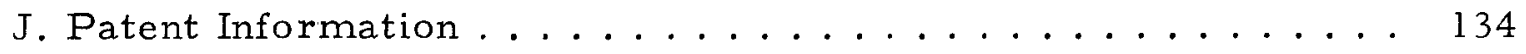

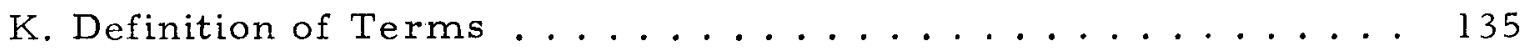

L. Applications to Other Potential Sponsors .......... 136

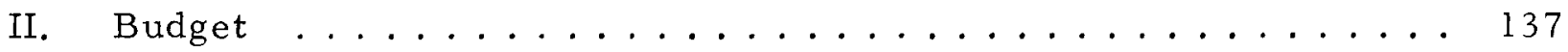

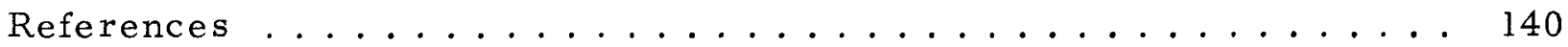

Appendices

A. An Assessment of Energy Capacity of the Salton Sea KGRA ................... A - 1

B. A Comparative Evaluation of Geothermal

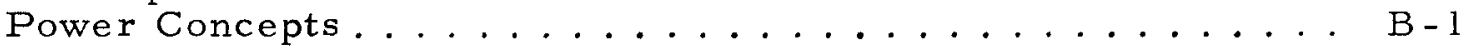

C. Bibliography - Environmental Analysis ............ C - l

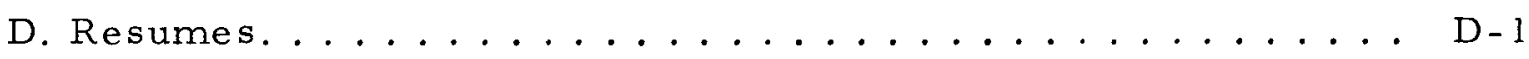




\section{TABLES}

Page

1. World Geothermal Electric Generating Stations ......... 11

2. Composition of Some North American Geothermal Brines . . . . . 20

3. Brine Compositional Indicators of Down-Hole Temperatures ........................ 22

4. Composition of Geothermal Steam from Various Sites ...... 24

5. Typical Problems Expected in Geothermal Brine Operations .... 26

6. Anticipated Corrosion Problems .............. . . 37

7. Summary of Cycle Studies . . . . . . . . . . . . . 41

8. Comparison of Alternative Geothermal Power Options . . . . . . . 42

9. Anticipated Minerals Production from 10-gpm Facility . . . . . 48

10. Organization of Area Resources Test Facility . . . . . . . . 55

11. Estimated Minerals Production Rates - Salton Sea KGRA Brines at $80 \%$ Recovery . . . . . . . . . . . . 


\section{FIGURES}

Page

1. Imperial Valley Geothermal Area . . . . . . . . . . . . . 18

2. Diagram of Quartz Solubility in Water .............. 28

3. The Solubility of Quartz, Cristobalite, and Amorphous Silica in Water Between 25 and $250^{\circ} \mathrm{C} \ldots \ldots \ldots . \ldots \ldots$

4. The Solubility Surface of Calcite in the System

$\mathrm{CaCO}_{3}-\mathrm{NaCl}-\mathrm{CO}_{2}-\mathrm{H}_{2} \mathrm{O}$ Between 50 and $300^{\circ} \mathrm{C}$, Between 0 and $70 \mathrm{~atm}$, and at a $\mathrm{NaCl}$ Concentration Near 1 Molal ........ 29

5. Preliminary Process Flowsheet, Minerals Recovery from Geothermal Brines......................... 49

6. Program Logic Diagram - Phase $0 \ldots \ldots 62$

7. Program Logic Diagram - Phase 1............... 65

8. Program Logic Diagram - Phase 2.............. 68

9. Project $\mathrm{Team} \ldots \ldots \ldots \ldots \ldots . \ldots \ldots . \ldots \ldots$

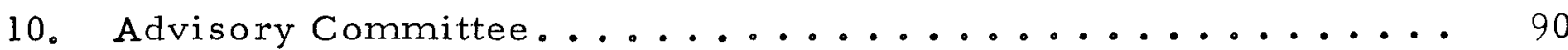

11. Southern California Edison Research and

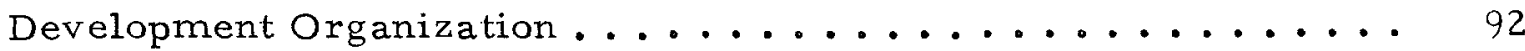

12. Hazen Research, Inc. Organization................. 94

13. Phillips Petroleum Company Organization ............. 96

14. Atomics International Organization ................ 97

15. AI Advanced Programs Organization ................ 98

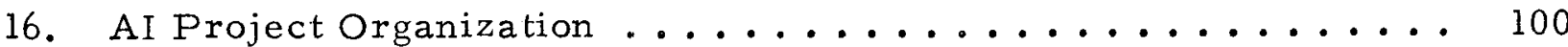

17. Salton Sea Geothermal Experimental Program

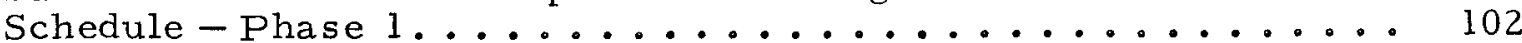

18. Imperial Valley Geothermal R\&D

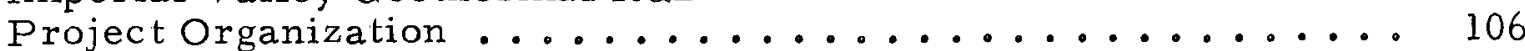


$$
-
$$

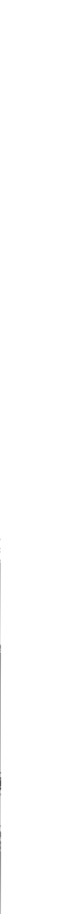

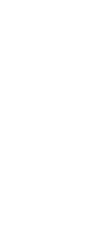




\section{ABSTRACT}

The proposed Salton Sea Geothermal Power Pilot Plant Program comprises two phases. The objective of Phase 1 is to develop the technology for power generation from the high-temperature, high-salinity geothermal brines existing in the Salton Sea known geothermal resources area. Phase 1 work will result in the following:

- Completion of a preliminary design and cost estimate for a pilot geothermal brine utilization facility.

- Design and construction of an Area Resource Test Facility (ARTF) in which developmental geothermal utilization concepts can be tested and evaluated.

Program efforts will be divided into four subprograms; Power Generation, Mineral Extraction, Reservoir Production, and the Area Resource Test Facility. The Power Generation Subprogram will include testing of scale and corrosion control methods, and critical power cycle components; power cycle selection based on an optimization of technical, environmental and economic analyses of candidate cycles; preliminary design of a pilot geothermal-electric generating station to be constructed in Phase 2 of this program.

The Mineral Extraction Subprogram will involve the following: selection of an optimum mineral recovery process; recommendation of a brine cleanup process for well injection enhancement; engineering, construction and operation of mineral recovery and brine clean-up facilities; analysis of facility operating results from environmental, economical and technical point of-view; preliminary design of mineral recovery and brine clean-up facilities of sufficient size to match the planned pilot power plant.

The Reservoir Production Subprogram will include monitoring the operation and maintenance of brine production, handling and injection systems which were built with private funding in Phase 0 , and monitoring of the brine characteristics and potential subsidence effects during well production and 
injection. Based on the above, recommendations and specifications will be prepared for production and injection systems necessary to serve the pilot power and mineral recovery plants planned for Phase 2.

The scope of the Area Resource Test Facility Subprogram will include evaluation, costing, design, construction and operation of an ARTF that can serve as a field facility for testing and evaluating high temperature, high salinity geothermal brine utilization components and systems being developed by various organizations and laboratories in the United States. 


\section{NARRATIVE}

\section{A. PROGRAM OBJECTIVES}

1. Statement of Problem

Geothermal energy is being utilized for the production of electric power on a small scale throughout the world. The total worldwide installed electric generating capacity using geothermal energy is about $1100 \mathrm{MW}$, of which $400 \mathrm{MW}$ is installed in the U. S. Table 1 lists major geothermal fields, their electric capacity and the type of reservoir utilized.

TABLE 1

WORLD GEOTHERMAL ELECTRIC GENERATING STATIONS

\begin{tabular}{l|l|c|c}
\hline \multirow{2}{*}{ Country } & Field & $\begin{array}{c}\text { Installed } \\
\text { Capacity } \\
(\mathrm{MW})\end{array}$ & Reservoir Type \\
\hline \multirow{2}{*}{ Italy } & Larderello & 360 & Vapor-dominated \\
& Monte Amiata & 25 & Vapor-dominated \\
United States & The Geysers & 400 & Vapor-dominated \\
New Zealand & Wairakei & 190 & Liquid-dominated \\
Other & Cerro Prieto & 75 & Liquid-dominated \\
Total & & 50 & Vapor and liquid \\
\hline
\end{tabular}

As the table indicates, about $75 \%$ of the world geothermal capacity is installed at vapor-dominated fields. Although vapor-dominated fields contain the vast majority of electric capacity at the present time, it is expected that most new geothermal fields discovered and exploited in the U. S. will be of the 1 iquid-dominated type. There are currently no geothermal generating stations in the U. S. utilizing liquid-dominated reservoirs.

The liquid-dominated systems found in the U. S. to date vary in temperature from below $200^{\circ} \mathrm{F}$ to over $600^{\circ} \mathrm{F}$, and in salinity from less than $2000 \mathrm{ppm}$ to greater than $300,000 \mathrm{ppm}$. That part of the Salton Sea known geothermal resources area (KGRA) where this project is located contains geothermal 
brines with salinities in excess of $300,000 \mathrm{ppm}$ and temperatures over $600^{\circ} \mathrm{F}$. The total energy content of the Salton Sea KGRA as estimated by several investigators is considerable and capable of providing 2,000 to $30,000 \mathrm{MWe}$ centuries (see Appendix A).

This unique geothermal area has been known to exist since the early 1850's. An initial attempt to exploit the natural resources of the geothermal area resulted in three exploratory steam wells being drilled in 1927, but the first deep hole discovery well of any significance was not drilled until 1957. Subsequent to that time, three well-financed, in-depth investigations of Salton Sea area geothermal resources were completed. First of these was a thoroughly exhaustive work effort conducted by the Special Projects Department of Shell Oil Company during 1963 and 1964. The second effort was performed by Pure-Union Oil in the mid-1960's. The third major effort was that conducted by Morton Salt Company in the period of 1965 through 1966. The "modern" period from 1957 to the present has seen several lesser investigations which contribute only minor additional information to the store of area knowledge.

The basic character of this resource can be inferred from a summary by Helgeson of four Shell-operated wells. These four wells were reported capable of producing $1,750,000$ pounds per hour mass flow at 275 psia well head pressure, and, of that flow, 300,000 pounds per hour were steam. Production of the four wells in a single day was expected to bring to the surface approximately 9,000 tons of solid material dissolved in the brine; the enthalpy of the mass flow ranged from 400 to 500 BTU per pound. Formation fluids contained from 210,000 to 270,000 parts per million dissolved solids and after flashing the post-flash brines reached concentrations greater than 300,000 parts per million. The brine solute is reported by Helgeson to contain predominately chloride salts of sodium, calcium and potassium, with smaller amounts of iron, manganese, silica, strontium, and lithium, and significant but lesser quantities of lead, zinc, copper and silver.

Hydrothermal brine of such an exotic composition and degree of concentration is obviously the product of equilibrium saturation between the hot water and earth minerals at reservoir conditions of pressure and temperature. 
Temperature of the geothermal reservoir exceeds $600^{\circ} \mathrm{F}$ and pressure is equivalent to normal hydrostatic pressure with depth. The process of geothermal energy conversion to electricity must be accompanied by a reduction of pressure and/or temperature and, therefore, results in a super-saturated solution. Deposition of the excess solids to produce a solution again in equilibria at conditions of reduced pressure and temperature results in the formation of extremely large volumes of scale. It is this scale formation in every element of surface equipment that has been the most significant factor in failure of each attempt to date to utilize the vast potential of heat and minerals in this natural resource.

During the early $1970^{\prime}$ 's there has been renewed interest in exploitation of the Salton Sea KGRA. Many investigators have attempted, unsuccessfully, to produce power using the brines contained in the KGRA. To date, no technology has been developed which will allow commercial generation of electric power using these hypersaline brines. Such technology, once developed, may require mineral extraction facilities in order to be economically attractive.

Many organizations are in the process of developing processes and components which may facilitate the production and utilization of hypersaline brines to generate power or for utilization of brines for non-electric purposes. The components include total-flow turbomachinery, down-hole pumps, down-hole heat exchangers, and geothermal well instrumentation. Processes under development include means for scale control, mineral recovery, and heat utilization. A field test facility in which these developmental concepts can be tested and evaluated is needed.

\section{Objectives}

The goal of the Salton Sea Geothermal Power Pilot Plant Program is to establish the technology for economic utilization of the hypersaline geothermal brines in the Salton Sea KGRA. Objectives of the overall program include the following:

- To develop the technology necessary for commercial production of electric power from hypersaline brines in the Salton Sea KGRA. 
- Design and construction of an Area Resource Test Facility in which developmental geothermal utilization concepts can be tested and evaluated.

The objectives of the planned follow-on Phase 2, Pilot Plant Efforts, are the following:

- To design, construct and operate a pilot scale (10 MWe equivalent) geothermal brine utilization facility. (A study will be made during Phase 1 to determine the risks associated with bypassing the pilot plant and going directly to a $50 \mathrm{MWe}$ demonstration plant.)

- To continue operation of the Area Resource Test Facility completed in Phase 1.

- To complete a preliminary design and cost estimate for a demonstration or commercial (about 50 MWe equivalent) geothermal brine utilization facility.

If Phase 2 reveals a need for a demonstration plant, a Phase 3, Demonstration Plant Efforts, will have the following objectives:

- To design, construct and operate a demonstration geothermal resource utilization facility.

- To determine the feasibility of constructing a commercial geothermal utilization facility using Salton Sea KGRA brines.

\section{Specific Questions to be Answered}

The proposed Phase 1 efforts are designed to answer specific questions regarding the utilization of the Salton Sea KGRA. In order to answer these questions, experimental equipment will be installed and operated near existing Sinclair Wells 3 and 4. These wells are located approximately 14 miles northwest of Brawley, California near the southern end of the Salton Sea.

Experiments to provide the technology for commercial utilization of Salton Sea KGRA brines in the near term (next 10 years) will be conducted under the subprograms entitled Power Generation, Mineral Recovery and Reservoir Production. Technology for implementation in the longer term 
(greater than 10 years) based upon advanced system and component development can be tested and evaluated in the facilities provided under the subprogram entitled Area Resource Test Facility.

Specific questions that will be answered in Phase 1 of the program are listed below:

\section{a. Power Generation}

- What methods can be applied to minimize scale formation, corrosion and erosion of surfaces critical to the generation of power?

- What is the optimum power generation cycle from an environmental, economic and technical standpoint?

- Which type of power generation components are best suited to power production from these brines?

- What constituents of the hydrothermal fluids are potentially hazardous if released into the environment?

- Assuming closed heat exchange systems cannot be made operational, can the condensed steam effluents be traded for poor quality cooling water from surface resources to minimize impact on the environment or to enhance present environmental quality?

- Which energy conversion process will be most ecologically compatible?

b. Mineral Recovery

- Will mineral recovery processes be ecologically compatible?

- Does mineral recovery have the potential of enhancing the economics of power generation?

- What methods and/or materials can be applied to minimize scaling, corrosion and erosion of critical surfaces and components of mineral recovery equipment?

\section{c. Reservoir Production}

- Can these brines be successfully produced and injected on a long-term basis? 
- Will brine clean-up systems be required in order to make longterm injection feasible?

- What are the effects of brine production and injection during the program on possible subsidence problems?

- What are the physical characteristics of the brine (temperature, pressure, dissolved solids, etc.) as a function of time?

- Will additional wells be required for a pilot utilization plant?

\section{d. Area Resource Test Facility}

- What processes or equipment can be developed to allow more efficient exploration for and power production from these brines in the next decade?

- What processes or equipment can be developed to allow production of useful water or heat from these brines in the next decade?

- What is the extent of the Salton Sea KGRA and how long will it last?

\section{Benefits}

The benefits which will accrue from the successful completion of the proposed Phase 1 program, and its logical follow-on efforts can be broken down into two categories: long-range benefits based on commercial-scale utilization of Salton Sea KGRA brines, and short-term benefits resulting from the Phase 1 experimental program.

\section{a. Long-Range Benefits}

Assuming successful completion of Phases 1 and 2 of this program, utilization of Salton Sea KGRA brines on a commercial scale will result. This commercial utilization will act to reduce the dependence of this country on imported fossil fuels and may offer the additional benefit of increasing domestic production of certain scarce minerals.

\section{b. Short-Term Benefits}

Because the geothermal brines being investigated are among the most saline known, the results of Phase 1 offer the promise of being generalized 
to other less saline brines. This generalizability will act to accelerate the development of geothermal utilization by eliminating some of the "front-end" experimental efforts that would normally precede large-scale development.

The availability of the Area Resource Test Facility to government sponsored and privately funded organizations and individuals who are involved in the development of geothermal energy systems for both electric and nonelectric applications will act as a catalyst in accelerating the development of advanced concepts for utilization of high temperature, high salinity brines. Probably one of the most severe brine conditions to be encountered in waterdominated systems is directly available at the Sinclair well site; also, closed loops containing brines of other properties could be provided as required. The ARTF will also result in a significant cost benefit since it will eliminate the necessity for each organization to construct its own field test facilities for investigating the performance of specific concepts. Since the ARTF can be operated with procedures to protect proprietary concepts and devices, there will be minimal need for organizations to spend funds in gaining access to geothermal wells and in constructing the basic brine supply, handling, storage, and disposal systems. In addition, the ARTF will be beneficial in providing an up-to-date source of information pertinent to the application and utilization of geothermal resources. 


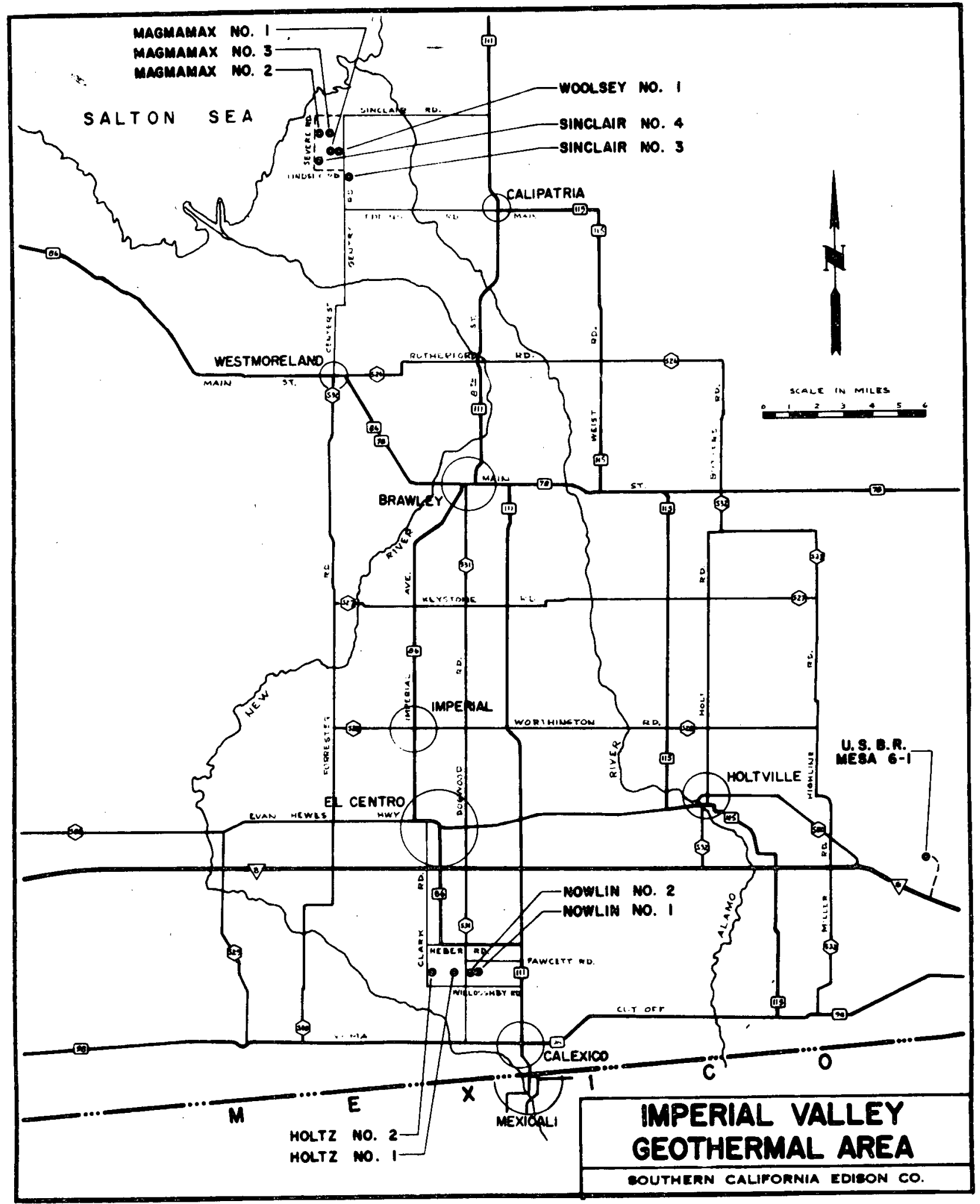

Figure 1. Imperial Valley Geothermal Area 


\section{B. PROGRAM PLAN}

\section{Program Accelerating Factors}

Certain knowledge and physical facilities available to the project team for this program will allow more timely completion of a successful program than might be possible with another team. Those considerations which are important in attaining this program's objectives in an expeditious manner are discussed below. In addition the specific knowledge and material available to the project relating to these considerations are noted.

\section{a. Site}

Southern California Edison Company (SCE), Phillips Petroleum Company (PPC) and Southern Pacific Land Company (SPL) have entered into a Geothermal Energy and Minerals Research and Development Agreement which entitles the Participants (see Section $\mathrm{K}$ for definition of terms) to use about 34,000 acres of geothermal leases in the Salton Sea KGRA. These leases, owned jointly by Mono Power Company (a subsidiary of SCE), PPC and SPL, are located at the Southeastern end of the Salton Sea in the Buttes area. Two wells on the lease site, Sinclair No. 3 and 4 , have been reworked and an injection pipeline has been installed between them. The wells and pipeline are operable. Figure 1 shows the location of the wells with respect to neighboring communities and other geothermal wells in the Imperial Valley.

In addition to the production and injection systems currently installed at the site, the Participants plan to have an operable inter-well brine handling system installed in the second quarter of 1975. This system, designated the SemiClosed Injection System, will include a steam/brine separator, flash tank, surge tank, brine cooling system and connections to allow testing of various geothermal brine utilization concepts. This system will be made available by the Participants for the proposed work.

The availability of the leased land and operable brine production, handling and injection systems is a major reason why the program can be completed in an expeditious manner. There will be no need to drill exploratory wells to "proveup" a geothermal resource prior to beginning the research program described in this proposal - a process which could add years of delay in accomplishing program objectives. 
TABLE 2

COMPOSITION OF SOME NORTH AMERICAN GEOTHERMAL BRINES

\begin{tabular}{|c|c|c|c|c|c|}
\hline \multirow[b]{2}{*}{$\begin{array}{c}\text { Component or } \\
\text { Property }\end{array}$} & \multicolumn{5}{|c|}{ Brine Source/Content (ppm) } \\
\hline & $\begin{array}{c}\text { Shell No. } 2 \\
\text { IID } \\
\text { (Ca, USA) }\end{array}$ & $\begin{array}{c}\text { Shell No. } 1 \\
\text { State } \\
\text { (Ca, USA) }\end{array}$ & $\begin{array}{c}\text { Cerro } \\
\text { Prieto } \\
\text { (Mexico) }\end{array}$ & $\begin{array}{l}\text { Mesa 6-1 } \\
\text { (Ca, USA) }\end{array}$ & $\begin{array}{c}\text { Sinclair } \\
\text { No. } 4 \\
\text { (Ca, USA) }\end{array}$ \\
\hline Sodium & 53,000 & 47,800 & $4,450-6,100$ & $7,960-10,939$ & $62,600-80,500$ \\
\hline Potassium & 16,500 & 14,000 & $504-1,860$ & $1,047-1,412$ & $14,000-19,100$ \\
\hline Lithium & 210 & 180 & $12-19$ & - & $192-257$ \\
\hline Barium & 250 & 190 & $\sim 12$ & - & $1,200-1,630$ \\
\hline Calcium & 28,800 & 21,200 & $210-390$ & $1,020-1,635$ & $25,700-35,200$ \\
\hline Strontium & 440 & - & $\sim 10$ & - & $513-640$ \\
\hline Magnesium & 10 & 27 & $6-33$ & $10-40$ & $50-113$ \\
\hline Boron & 390 & 290 & $4-21$ & - & $100-270$ \\
\hline Silica & 400 & - & $151-770$ & $100-220$ & $415-675$ \\
\hline Iron & 2,000 & 1,200 & 0.2 & - & $1,130-1,680$ \\
\hline Manganese & 1,370 & 950 & 0.64 & - & $1,470-1,820$ \\
\hline Lead & 80 & 80 & 5 & - & $80-117$ \\
\hline Zinc & 500 & 500 & - & - & $322-425$ \\
\hline Copper & 3 & 2 & - & - & $2.4-4.4$ \\
\hline Silver & $<1$ & $<1$ & - & - & $0.35-0.55$ \\
\hline Rubidium & 70 & 65 & - & - & - \\
\hline Cesium & 20 & 17 & - & - & - \\
\hline Chloride & 155,000 & 127,000 & $7,420-11,750$ & $14,300-20,730$ & $130,725-172,200$ \\
\hline$\sum \mathrm{CO}_{2}$ & 500 & 5,000 & $0-1,600$ & $44-318^{*}$ & - \\
\hline$\sum S$ & 30 & 30 & $0-700$ & - & - \\
\hline $\begin{array}{l}\text { Total Dis solved } \\
\text { Solids }\end{array}$ & 259,000 & 219,500 & & $26,200-35,110$ & $238,500-314,600$ \\
\hline
\end{tabular}

$*=\mathrm{HCO}_{3}$

†After flashing

-No data available on this component 


\section{b. Geothermal Brine Properties}

Selection of the optimum power cycle, construction materials, and the necessary process subsystems that will be applicable to commercial power generation from the Salton Sea KGRA are strongly dependent upon the chemical and physical properties of the brine resource. Knowledge of the brine properties is therefore essential to the design of a suitable geothermal power plant system. Data are available from the Buttes Area (Sinclair No.4) and from other related KGRA's. These data, the significant characterizing parameters, and a discussion of their influence upon power plant design are presented her presented herein.

\section{(1) Parameters Characterizing Geothermal Brines}

The major parameters pertinent to power generation that characterize brines from water-dominated geothermal sources are: (1) temperature, (2) salinity, (3) silica content, (4) noncondensible gas content and composition, and (5) mineral content. The significance of these properties in general and for the Salton Sea Buttes area (Sinclair No. 4 well) brines, in particular, is dis cussed in the following sections.

First, however, it is important to consider the approximate compositions of several relevant geothermal brines as reported by a number of investigators. These brine compositions, shown in Table 2, include three separate brines from the Buttes area, designated as Shell No. 2, Shell No. 1, and Sinclair No. 4, the Mesa 6-1 brine, and the Cerro Prieto, Mexico brine. It is to be noted that these brines have distinctly different composition, including the three from the Buttes area (note the barium and the $\mathrm{CO}_{2}$ levels). It is expected that the re also may be considerable variation in brine composition from a single well as a function of operating time. The influence of brine composition is discussed below as it relates to major brine parameters.

\section{(a) Temperature}

The downhole temperatures of geothermal brines are found to vary from $200^{\circ} \mathrm{F}$ or less to over $650^{\circ} \mathrm{F}$ in some cases. This temperature is found to correlate $(1,2)$ with a number of compositional parameters which may serve as an 
TABLE 3

BRINE COMPOSITIONAL INDICATORS OF DOWN-HOLE TEMPERATURES

\begin{tabular}{|c|c|}
\hline Indicator & Comments \\
\hline 1. $\mathrm{SiO}_{2}$ content & $\begin{array}{l}\text { Best of indicators; assumes quartz equili- } \\
\text { brium at high temperature with no dilution } \\
\text { or precipitation after cooling. }\end{array}$ \\
\hline 2. $\mathrm{Na} / \mathrm{K}$ & $\begin{array}{l}\text { Generally significant for ratios between } \\
20 / 1 \text { to } 8 / 1 \text { and for some systems outside } \\
\text { these limits. }\end{array}$ \\
\hline $\begin{array}{l}\text { 3. } \mathrm{Ca} \text { and } \mathrm{HCO}_{3} \\
\text { content }\end{array}$ & $\begin{array}{l}\text { Qualitatively useful for near-neutral waters; } \\
\text { solubility of } \mathrm{CaCO}_{3} \text { inversely related to sub- } \\
\text { surface temperatures. }\end{array}$ \\
\hline 4. $\mathrm{Mg}: \mathrm{Mg} / \mathrm{Ca}$ & $\begin{array}{l}\text { Low values indicate high subsurface tem- } \\
\text { perature, and vice versa. }\end{array}$ \\
\hline 5. Cl dilution & $\begin{array}{l}\text { Assumes dilution of lower-Cl springs by cold } \\
\text { water, permitting calculation of subsurface } \\
\text { temperatures from required mixing ratios } \\
\text { with highest } C l \text { waters. }\end{array}$ \\
\hline 6. $\mathrm{Na} / \mathrm{Ca}$ & $\begin{array}{l}\text { High ratios may indicate high temperatures } \\
\text { but not for high-Ca brine; less direct than } \\
\text { Indicator } 3 \text { above. }\end{array}$ \\
\hline 7. $\mathrm{Cl} / \mathrm{HCO}_{2}+\mathrm{CO}_{3}$ & $\begin{array}{l}\text { Highest ratios in related waters indicate } \\
\text { highest subsurface temperatures and vice } \\
\text { versa. }\end{array}$ \\
\hline 8. $\mathrm{Cl} / \mathrm{F}$ & $\begin{array}{l}\text { High ratios may indicate high temperatures } \\
\text { but } \mathrm{Ca} \text { content (as controlled by } \mathrm{pH} \text { and } \mathrm{CO}_{3} \\
\text { contents) prevents quantitative application. }\end{array}$ \\
\hline 9. $\mathrm{H}_{2}$ /other gases & $\begin{array}{l}\text { High ratios qualitatively indicate high } \\
\text { temperatures. }\end{array}$ \\
\hline 10. Sinte $\mathbf{r}$ deposits & $\begin{array}{l}\text { Reliable indicator of subsurface temperature } \\
\text { (now or formerly) }>350^{\circ} \mathrm{F} \text {. }\end{array}$ \\
\hline 11. Travertine deposits & $\begin{array}{l}\text { Strong indicator of low subsurface tempera- } \\
\text { tures unless bicarbonate waters have con- } \\
\text { tacted limestone after cooling. }\end{array}$ \\
\hline
\end{tabular}


indirect indication of the magnitude of the temperature. These indicators and comments on them are given in Table $3 .{ }^{(1)}$ In addition, there is a direct correlation between downhole temperature and salinity (Total Dissolved Solids). The approximate downhole temperature range of the Buttes area brines is $400-650^{\circ} \mathrm{F}$.

(b) Salinity (Total Dissolved Solids)

The magnitude of this parameter, and its make-up vary widely, generally being greater in the hotter brines. In all brines, the principal cation is $\mathrm{Na}^{+}$ while $\mathrm{Cl}^{-}$is the principal anion.

\section{(c) Silica Content}

This parameter correlates well with downhole temperature. The level corresponds to that of quartz at this temperature (see Section I-B-1-c, "Scaling and Corrosion").

\section{(d) Noncondensible Gases}

All geothermal brines contain some dissolved gases which are released when the pressure is reduced and which remain as gases after the system cools. The reported compositions of these gases in the steam from various geothermal sources are given in Table 4. It may be seen that the principal noncondensible gas is $\mathrm{CO}_{2}$ in all cases. This accounts for the low $\mathrm{pH}$ values (3-5) reported for many brines.

The noncondensible gases, as well as being principal potential contributors to corrosion throughout the geothermal processing system, act to develop backpressure in turbines using steam directly, thereby decreasing power output. This may be important in selection of a power generation cycle.

(e) Mineral Content

Aside from the salinity (TDS) and silica content, certain of the brine components are of special significance as (1) scale formers, or (2) valuable minerals. Some of the scale formers are $\mathrm{Ca}^{+2}$ (with $\mathrm{HCO}_{3}^{-} \mathrm{CaCO}$ ), $\mathrm{Fe}(\mathrm{II}), \mathrm{Mn}, \mathrm{Pb}$, $\mathrm{Ag}$, and other so-called heavy metals. The valuable minerals include $\mathrm{K}, \mathrm{Li}$, and $\mathrm{Ag}$. Their value depends on their concentration in the brine. At the 
TABLE 4

COMPOSITION OF GEOTHERMAL STEAM FROM VARIOUS SITES

\begin{tabular}{|c|c|c|c|c|c|}
\hline & $\begin{array}{l}\text { Larde- } \\
\text { rello }\end{array}$ & $\begin{array}{c}\text { The } \\
\text { Geysers }\end{array}$ & $\begin{array}{l}\text { Wair - } \\
\text { akei }\end{array}$ & $\begin{array}{c}\text { Buttes - } \\
\text { Salton } \\
\text { Sea }\end{array}$ & $\begin{array}{l}\text { Sinclair } \\
\text { No. } 4^{*}\end{array}$ \\
\hline $\begin{array}{l}\text { Total Noncondensibles } \\
(\text { mole } \%) \\
\text { Noncondensible Gas } \\
\text { Composition (mole \%) }\end{array}$ & 2.0 & 0.3 & 0.06 & 0.25 & - \\
\hline $\mathrm{CO}_{2}$ & 92.8 & 69.3 & 91.7 & 94 & 91 \\
\hline $\mathrm{H}_{2} \mathrm{~S}$ & 2.5 & 2.0 & 4.4 & $0.5-2.0$ & - \\
\hline $\mathrm{HC}$ & - & 11.8 & 0.9 & $0.25-4$ & 1.5 \\
\hline $\mathrm{H}_{2}$ & - & 12.7 & 0.8 & $0.5-4$ & - \\
\hline $\mathrm{NH}_{3}$ & 1.7 & 1.6 & 0.6 & $\dagger$ & - \\
\hline $\mathrm{H}_{3} \mathrm{BO}_{3}$ & 0.45 & - & 0.05 & - & - \\
\hline $\mathrm{N}_{2}$ & - & - & - & $0.5-2.0$ & 7 \\
\hline
\end{tabular}

NOTES: 1. The above represent approximate average values from a number of drill holes.

2. The data in firest three columns are from Ellis, A. J., "Quantitative Interpretation of Chemical Characteristics of Hydrothermal Systems, "Geothermics (1970) Special Is sue 2, pages 516-528.

-No data

* Gases after condensation of total brine flow

$\dagger 400$ to $500 \mathrm{ppm} \mathrm{HN}_{3}$ in condensate

Sinclair No. $4 \mathrm{Well}$, the recoverable minerals which appear to be of value include $\mathrm{CaCl}_{2}$ (and $\mathrm{KCl}$ and $\mathrm{NaCl}$ ), $\mathrm{Zn}, \mathrm{Li}_{2} \mathrm{CO}_{3}, \mathrm{SrCO}_{3}$, and $\mathrm{MnO}_{2}$. The potential for mineral recovery is discussed further in Section B.l.e of this proposal.

(2) Problems and Benefits Inherent in Brines

A high brine temperature offers the potential advantages of a higher power output for a given brine flow. Normally associated with high brine temperatures are: (1) higher salinity, which can impose salt handling and corrosion problems, 
(2) higher silica leading to scaling problems, and (3) higher mineral content, which may result in the use of mineral recovery to improve cycle economics. The salinity and temperature, together with the noncondensible gases primarily determine the corrosion environment of the geothermal brine-steam containment system.

The iron content may play a major role in scale formation when its concentration is significant as it is at Sinclair No.4. In such brines, both silica and iron are found together in scale often in nearly stoichiometric ratios. Under these conditions the presence of iron can promote silica scaling which might not otherwise occur.

\section{(3) Requirements for Resource Development}

Electric power generation from the high salinity brines of the Buttes area will require material compatibility studies. The problems of scaling and corrosion are of special significance. Other critical problems are: (1) clean separation of steam and brine, (2) brine handling and reinjection, and (3) cooling and make-up water supply.

In processes using steam flashed directly from the brine, problems with deposits and corrosion from carried-over impurities will be of great importance. Besides the brine itself, the volatile $\mathrm{H}_{3} \mathrm{BO}_{3}$, silica, and the noncondensible gases pose potential problems.

\section{c. Scaling and Corrosion}

\section{(1) Overview of the Problems}

The development of economic geothermal power using fluids originating from liquid dominated systems is significantly dependent on the ability to control scaling and corrosion. Of these, scaling is the most critical, as proper selection of materials will solve the corrosion problem, but effective scale control methods have yet to be developed.

These problems differ in kind and degree for the various geothermal sources. Based on experience to date, they are most severe in the high salinity, high temperature brines of the Buttes area, such as that from Sinclair No. 4. Some general comments as to the site and nature of the problems and the types of solutions which look promising are summarized in Table 5. 
TABLE 5

TYPICAL PROBLEMS EXPECTED IN GEOTHERMAL BRINE OPERATIONS

\begin{tabular}{|c|c|c|}
\hline & Technical Problem & Possible Solutions \\
\hline & $\begin{array}{l}\text { Scale Deposition in } \\
\text { Wells }\end{array}$ & $\begin{array}{l}\text { 1. Clean out casing periodically. } \\
\text { 2. Use separate production tube extending } \\
\text { to greater depth than producing zone. } \\
\text { 3. Control velocity in flash zone } \\
\text { 4. Prevent or minimize flashing in well. } \\
\text { 5. Inject suitable seed particles. }\end{array}$ \\
\hline B. & $\begin{array}{l}\text { Scale Deposition in Sur- } \\
\text { face Production Lines } \\
\text { and Components }\end{array}$ & $\begin{array}{l}\text { 1. Design to localize scale deposition onto } \\
\text { replaceable or cleanable elements. } \\
\text { 2. Optimize flow velocity (wall shear) to } \\
\text { prevent deposition. } \\
\text { 3. Inject special seed particles. } \\
\text { 4. Apply selected in situ control technique. }\end{array}$ \\
\hline C. & $\begin{array}{l}\text { Corrosion of Production } \\
\text { Equipment }\end{array}$ & $\begin{array}{l}\text { 1. Eliminate air entry even during shutdown. } \\
\text { 2. Use special alloys. } \\
\text { 3. Use plastic or rubber coatings. } \\
\text { 4. Permit some scale buildup to act as pro- } \\
\text { tective coating. }\end{array}$ \\
\hline D. & $\begin{array}{l}\text { Corrosion (or Plugging) } \\
\text { of Turbine and Con- } \\
\text { denser (when flashed } \\
\text { steam used directly) }\end{array}$ & $\begin{array}{l}\text { 1. Contact flashed steam at full pressure } \\
\text { with fresh water or alkaline solution to } \\
\text { absorb brine droplets and acid gases } \\
\text { ( } \mathrm{CO}_{2}, \mathrm{H}_{2} \mathrm{~S}, \mathrm{H}_{3} \mathrm{BO}_{3} \text { ) } \\
\text { 2. Use special alloys. } \\
\text { 3. Avoid air inleakage. } \\
\text { 4. Use direct contact condenser (to avoid } \\
\text { tube corrosion). } \\
\text { 5. Raise pH of brine. }\end{array}$ \\
\hline E. & $\begin{array}{l}\text { Scale Deposition in Brine } \\
\text { Discharge Lines }\end{array}$ & $\begin{array}{l}\text { 1. Maintain high velocity flow. } \\
\text { 2. Prevent uncontrolled flashing or cooling. } \\
\text { 3. Provide nuclei for deposition in the bulk } \\
\text { of the fluid rather than on the walls. } \\
\text { 4. Design for easy cleaning. } \\
\text { 5. Mechanical scraping devices. }\end{array}$ \\
\hline F. & Reinjection Well Plugging & $\begin{array}{l}\text { 1. Provide adequate settling ponds before } \\
\text { reinjection of brine. } \\
\text { 2. Filter brine. } \\
\text { 3. Operate so that reinjected brine is not } \\
\text { saturated with regard to any component } \\
\text { (i.e., dilute, reheat, or control } \\
\text { processing). }\end{array}$ \\
\hline
\end{tabular}


The problems cited in Table 5 will be common to all geothermal brine processing. However, the types of scale and severity of corrosion will depend on the physical and chemical properties of each brine. In the following sections, scaling and corrosion problems are considered in more detail with emphasis on the Buttes area brine.

\section{(2) Scaling and Its Control}

\section{(a) The Scale Forming Components of Geothermal Brines}

For the liquid dominated system, in situ pressures are normally such that the geothermal brines are entirely liquid. Under these conditions, in addition to the salt content, the brines become saturated with components of the rocks with which they are in contact, e.g., silica (quartz). These compounds, together with $\mathrm{H}_{3} \mathrm{BO}_{3}$, the salinity, the acidic gases $\left(\mathrm{H}_{2} \mathrm{~S}\right.$ and $\left.\mathrm{CO}_{2}\right)$, and ammonia $\left(\mathrm{NH}_{3}\right)$ are expected to be the major source of problems in the generation of power from the geothermal brines. Accordingly, an examination of their concentration and condition in situ, and changes occurring in removal and processing is in order.

The solubility of quartz in water has been thoroughly explored by a number of investigators. (3) A summary diagram of this solubility is shown in Figure 2. It will be seen that while the solubility is a function of pressure, up to about $300^{\circ} \mathrm{C}\left(570^{\circ} \mathrm{F}\right)$ the temperature will be of greatest importance in determining silica content of the brines. Several investigators have concluded that the silica content of water from hot springs corresponds to the equilibrium solubility of quartz at system temperature. Other forms of $\mathrm{SiO}_{2}$ are more soluble in water than is quartz, as shown in Figure 3. Under certain conditions (see below), the silica content of geothermal brines may correspond to amorphous silica solubility rather than quartz solubility.

The solubility of the $\mathrm{SiO}_{2}$ polymorphs in aqueous solutions is almost independent of the concentration of dissolved salts, although a slight decrease is effected at elevated water temperature by addition of chlorides. Also, the solubility of silica appears to be essentially independent of $\mathrm{pH}$ over the range of temperature and pressure of concern here. ${ }^{(3)}$ 


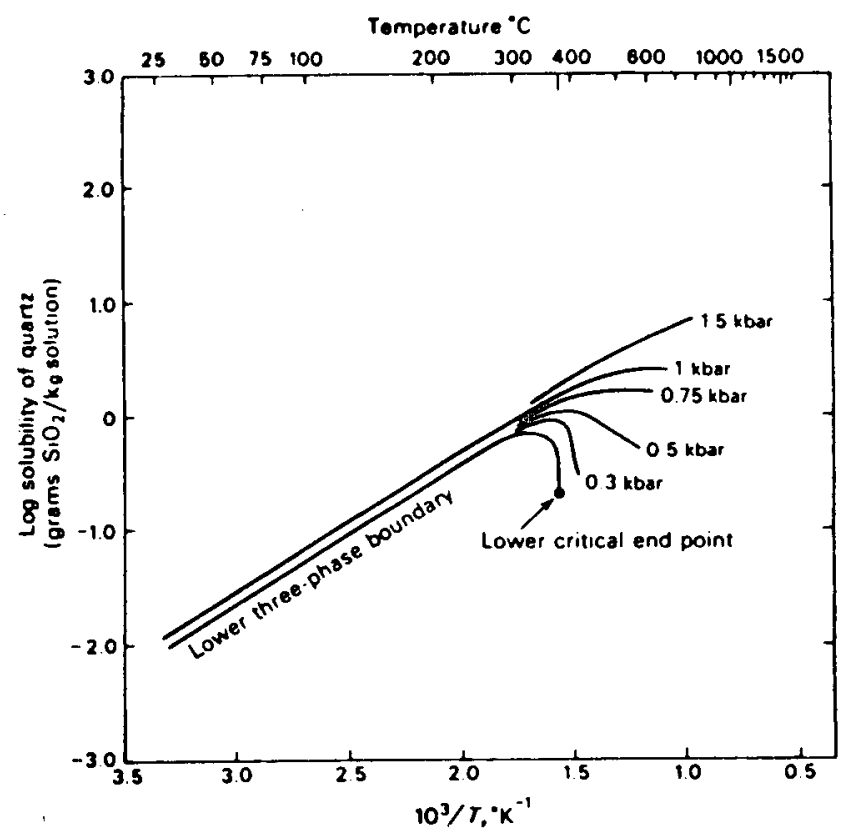

Figure 2. Diagram of Quartz Solubility in Water

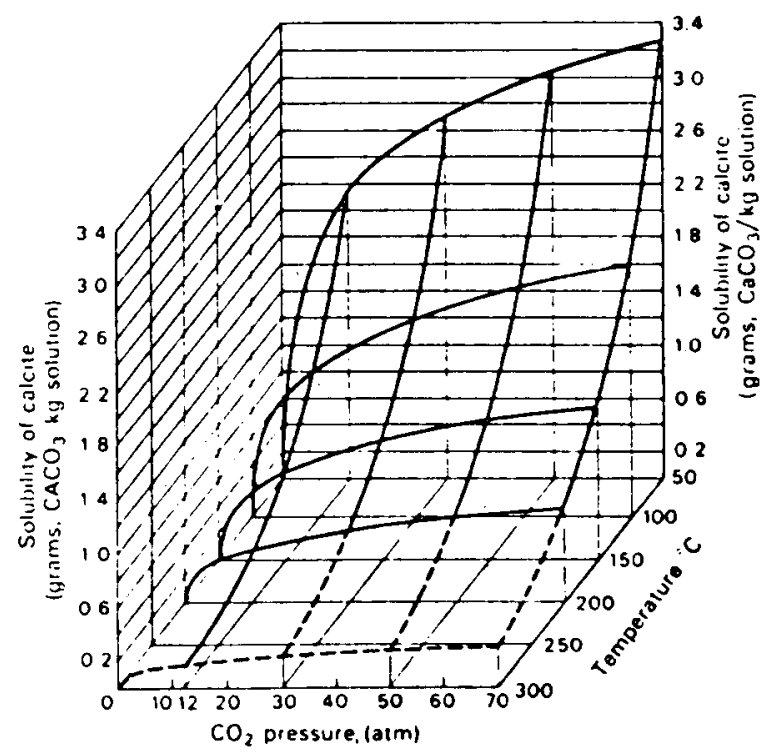

Figure 3. The Solubility of Quartz, Cristobalite, and Amorphous Silica in Water Between 25 and $250^{\circ} \mathrm{C}$ 
Calcium silicate $\left(\mathrm{CaSiO}_{3}\right)$ and complex calcium silicates (e.g., pectolite, $\left.\mathrm{NaHCa}_{2}\left(\mathrm{SiO}_{3}\right)_{3}\right)$ are known to be relatively insoluble, but their solubility is not known under conditions to be encountered in geothermal brine processing.

While calcium carbonate was not found in solids deposited in the processing equipment at Sinclair No. 4 or at Cerro Prieto, it has been encountered in processing the Mesa area geothermal brines. Any treatrnent of the Sinclair No. 4 brine which raises the $\mathrm{pH}$ (e.g., $\mathrm{NH}_{3}$ injection) can be expected to produce $\mathrm{CaCO}_{3}$ deposition.

The solubility of calcite (calcium carbonate) has been investigated as a function of $\mathrm{CO}_{2}$ pressure in water and in sodium chloride solution. The solubility surface of calcite in the system CaCO $3-\mathrm{NaCl}-\mathrm{CO}_{2}-\mathrm{H}_{2} \mathrm{O}$ is shown in Figure 4. As may be seen in Figure 4, calcite solubility increases with decreasing temperature while decreasing with decreasing $\mathrm{CO}_{2}$ pressure. Both of these effects occur simultaneously with the flashing of brine. Thus, the occurrence of calcium carbonate precipitation is dependent on the particular brine and processing scheme used.

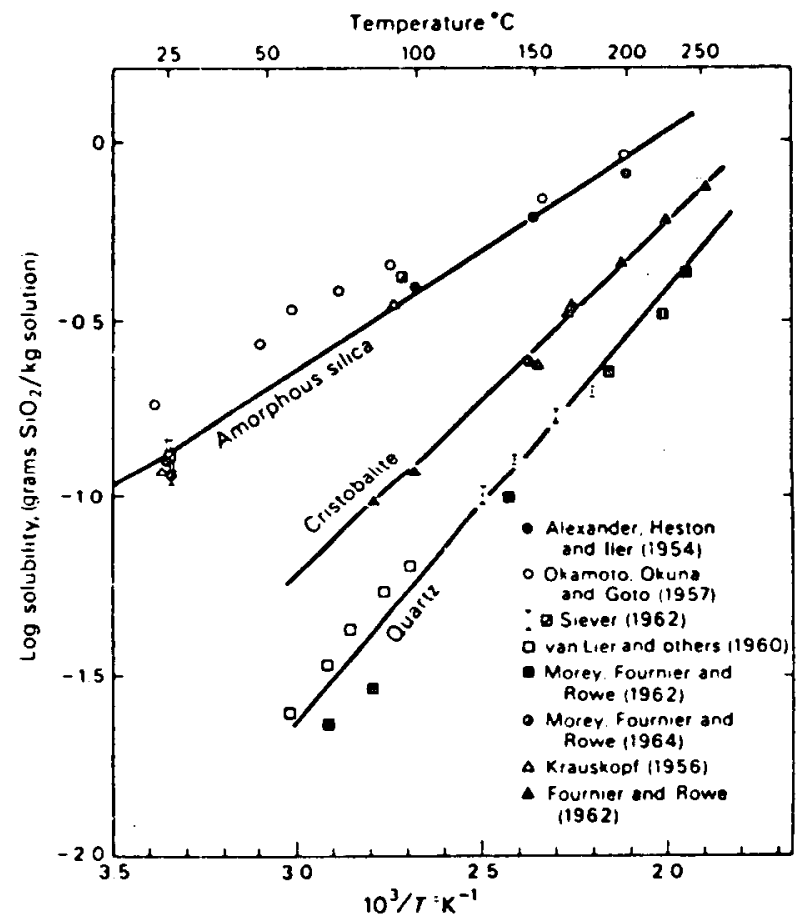

Figure 4. The Solubility Surface of Calcite in the System $\mathrm{CaCO}_{3}-\mathrm{NaCl}-\mathrm{CO}_{2}-\mathrm{H}_{2} \mathrm{O}$ Between 50 and $300^{\circ} \mathrm{C}$, Between 0 and 70 atm, and at a $\mathrm{NaCl}$ Concentration Near 1 Molal 


\section{(b) Processes Occurring in Geothermal Brine}

In the course of flowing geothermal brines from their underground location, through the well, and into a processing unit, pressure and temperature are reduced. This leads to the following processes:

1) Water vaporizes, forming a two-phase mixture of steam and brine.

2) Dissolved gases escape from the brine into the vapor phase.

3) The solution becomes supersaturated with respect to silica as the temperature is lowered and precipitation of hydrated amorphous silica (opal) will occur, together with iron oxide in some cases.

4) Calcium silicate or complex silicates may precipitate as a result of temperature decrease. Changes in pH resulting from escape of acid gases $\left(\mathrm{CO}_{2}\right.$ and $\left.\mathrm{H}_{2} \mathrm{~S}\right)$ and escape of $\mathrm{NH}_{3}$ will affect the process, but in an unknown fashion.

5) Calcite will tend to precipitate; this will be a result, primarily, of loss of $\mathrm{CO}_{2}$ pressure, as the temperature decrease will work in the opposite direction.

These processes, depending on the specific nature of the geothermal brine, will lead to the scaling problems which can be expected in subsequent processing of the brines.

The brines of Sinclair No. 4 well and others in the Buttes-Salton Sea Area (see Table 2) have a significant content of metal ions in a low (reduced) valence state. In particular, $\mathrm{Fe}$ (II) and $\mathrm{Mn}$ (II) are present at the several tenths percent level.

Fe (II) has been found to co-deposit with silica in the scale formed from these brines in what appears to be stoichiometric proportion. It thus contributes to the scaling problem; this is in contrast to the scale formed (to a less severe degree) at Cerro Prieto which is primarily $\mathrm{SiO}_{2}$.

The presence of Fe (II) will aggravate the corrosive effect of air entry into this high chloride brine. The low $\mathrm{pH}$ of the brine (3-5) will be further lowered by the reactions: 


$$
\begin{aligned}
& 2 \mathrm{FE}(\mathrm{II})+1 / 2 \mathrm{O}_{2}+\mathrm{H}_{2} \mathrm{O} \rightarrow 2 \mathrm{Fe}(\mathrm{III})+2 \mathrm{OH}^{-} \\
& 2 \mathrm{Fe}(\mathrm{III})+6 \mathrm{H}_{2} \mathrm{O} \rightarrow 2 \mathrm{Fe}(\mathrm{OH})_{3}+6 \mathrm{H}^{+}
\end{aligned}
$$

or, overall:

$$
2 \mathrm{Fe}(\mathrm{II}) 1 / 2 \mathrm{O}_{2}+5 \mathrm{H}_{2} \mathrm{O} \rightarrow 2 \mathrm{Fe}(\mathrm{OH})_{3}+4 \mathrm{H}^{+}
$$

thus enhancing further the corrosiveness of a very corrosive brine.

(c) Scaling at Sinclair No. 4

Silica is the principal component in the scale formed in high and moderate temperature geothermal brines. Amorphous silica is the form encountered. Its solubility is strongly dependent on temperature, being ten times greater at geothermal temperatures of say $600^{\circ} \mathrm{F}(\sim 1000 \mathrm{ppm})$ than at ambient temperatures $(\sim 100 \mathrm{ppm})$. Thus while the higher brine temperatures of Sinclair No. 4 promise more efficient (thermodynamically) power generation, they are accompanied by higher rates and amounts of scaling.

In brine processing, high rates of scale deposition generally occur at locations where the brine has suddenly become supersaturated with silica and/or where there are sudden changes in flow conditions, such as downstream of orifices, where eddying turbulence may occur. Supersaturation will occur upon flashing, when steam is evolved, leaving a smaller quantity of a cooler brine.

The cation content and salinity are largely determined by the specific geothermal brine being processed, and thus depend on the location and depth of the geothermal well. The brines in the Buttes area of California's Imperial Valley (e.g., those from Sinclair No.4) are of very high temperature $\left(600^{\circ} \mathrm{F}\right.$ ) and salinity $(\sim 30 \%)$ along with a high silica content and a relatively high content of iron, manganese, and other metal cations.

Analysis of scale samples obtained from this region have shown high iron as well as silica content. The iron is present at levels approximating stoichiometric for ferrous silicate, though the scale is amorphous under $x$-ray examination so that no conclusions as to compounds in the scale can be drawn. 
The results of the work of previous projects in the Buttes area show that scale formation has plagued all Imperial Valley geothermal operations. Its control (and control of corrosion) has been judged as essential to successful operation.

Experience of SCE and its associates at Sinclair No. 4 has been similar to that reported by others. Analysis of scale in surface piping showed similar patterns and compositions with $\mathrm{Si}$ and $\mathrm{Fe}$ (presumably $\mathrm{SiO}_{2}$ and $\mathrm{FeO}$ ) the principal components. In like manner, San Diego Gas and Electric Co. reports ${ }^{(4)}$ that considerable quantities of lead were present along with the silica and iron in the scale they encountered in the Buttes area.

\section{(d) Scale Problems in Power Generation Systems}

An evaluation has been made of numerous power generation cycles for application to high temperature/high saline water dominated geothermal systems. As part of analytic investigations performed by AI for SCE, it was recommended that four basic cycles should be considered for further evaluations, with the final selection reserved until the results of proposed investigations conducted on scale and corrosion control, and field test results of power plant components under development become available.

The four basic cycles selected are:

1) Turbine operating directly on steam which is flashed from the brine then purified to remove entrained brine droplets.

2) Turbine operating on clean steam generated by a secondary flashed steam-to-water heat transfer system.

3) Secondary cycle using, e.g., an isobutane turbine with a flashed steam-to-isobutane heat transfer system.

4) The total flow system.

The four basic cycles have common potential scaling problems in the following areas of the power generation flow system:

1) Production well casing

2) Well head valve 
3) Flow system from well head valve to first major power plant component

4) Flow system leading in reinjection well

The cycles in which the well flow is flashed to produce steam and concentraed brine (Cycles No. 1, 2, and 3 above) have additional scaling problems within the flash evaporator and within the interconnecting lines if multiple flashing is used. For the Total Flow System, additional problems will arise in the nozzles, turbine, or other rotary machines.

(e) Candidate Methods for Scale Control

In work done for SCE, a number of potential scale prevention methods have been identified. Several of these methods appear promising, and those deemed to be practical will be tested in the proposed program.

The role of surface finish on scaling was mentioned previously. Smooth surfaces are believed to minimize scale by providing fewer surface irregularities to serve as nucleation sites, and by avoiding the crevices and rough regions which give nucleated scale a foothold permitting it to adhere strongly. Scale may be prevented by providing surfaces which are very smooth and provide essentially no nucleation sites or roughness. This may be achieved by using Teflon or other "non-stick" coatings, or by oil-wetting the critical surfaces. At the other extreme, a corroded (rough, oxide) surface should scale rapidly. Such a surface placed so the flashed brine encounters it before it encounters the critical surface (e.g., valves, orifices, etc.) may act to remove scale formers and thus prevent scaling on the critical surface.

Input of various forms of energy should affect the scaling process. Sonic and ultrasonic energy will cause small but violent agitation of the brine and/or critical surface. This should minimize scale adhesion and tend to prevent its growth and may, as well, provide a removal method. Heating of the critical surface may produce a local subsaturation in a normally supersaturated brine, and thus prevent scale deposition.

Several devices have been promoted which employ applied electric potential presumably to prevent and even dissolve scale. These are usually directed toward $\mathrm{CaCO}_{3}$ scale at near ambient temperatures. Some previous work done 
on desalinization programs indicates that $\mathrm{CaSO}_{4}$ scale nucleation is a function of surface potential; low voltages ( $<1$ vdc) are effective, so no electrolysis is involved. The method would seem to merit testing. To accomplish this, a component near the critical surface will be electrically isolated from the surface and DC voltages applied to the critical surface. In addition, the application of higher voltages (>2 vdc) should result in gas evolution; and will work to agitate nucleating scale, perhaps preventing its adherence and growth. This also should be tested.

Additives of all kinds, from tannings and polyelectrolytes to salts and sequestering agents, have been used successfully to prevent scale in water desalting plants. Upon further evaluation, some may be judged worthy of further testing.

Scale will form only when brine supersaturated in silica and other scale formers comes in contact with a surface. Having critical tubes porous or providing orifices upstream of critical components where either pure water or purified brine may be injected should thus aid in preventing scaling on the surfaces subjected to the injected fluid.

All the methods mentioned above are concerned with processes at the critical component or surface. Other methods which are applicable upstream of these components are worthy of testing. These involve either precipitation of scale formers, or promotion of controlled scaling.

Adjusting the $\mathrm{pH}$ will work either to cause precipitation of scale formers (probably at higher $\mathrm{pH}$ values), or to reduce their degree of supersaturation. Preliminary testing at Sinclair No. 4 has indicated that the method is of some value.

Precipitation of cations in the Sinclair. No. 4 brine may act to co-precipitate silica or act as nuclei on which silica will precipitate. Raising the pH will lead to precipitation of $\mathrm{Fe}(\mathrm{OH})_{2}, \mathrm{Mn}(\mathrm{OH})_{2}$, and possibly $\mathrm{SiO}_{2}$ along with them. Unfortunately, this will lead to $\mathrm{CaCO}_{3}$ precipitation also. Lime addition will have this effect, with the quantity of solid material flowing with the brine then being even greater. 
Injection of finely divided scale material or silica, into the brine to act as seed for scale formation may prove effective. The technique has been tested successfully with $\mathrm{CaCO}_{3}$ and $\mathrm{CaSO}_{4}$ scale in water desalination processes. Another technique (contact stabilization) which may prove practical is to pass the brine through a bed of high surface area material, preferably scale. This will produce scale deposition in the bed and eliminate brine supersaturation.

Only one practical, economic, and effective method for scale prevention or control is required. With the large number of potentially effective methods, one can be optimistic that a practical method will be developed. The fact that extensive laboratory studies of probable scale control methods will be in progress prior to initiation of this proposed program is an important factor in accelerating the resolution of scaling problems peculiar to high salinity brines and in assuring early availability of electric power from high salinity brine resources.

\section{(3) Corrosion Problems in Geothermal Brine Processing}

\section{(a) Nature of the Problem}

The known corrosivity of geothermal brines requires careful selection of brine containment materials in a geothermal power system. Four factors which can accelerate corrosion are (1) high salinity, especially chloride content; (2) high temperature; (3) low $\mathrm{pH}$; and (4) corrosive gases, including hydrogen sulfide, $\mathrm{CO}_{2}$, and $\mathrm{NH}_{3}$. A favorable factor, concomitant with the presence of $\mathrm{H}_{2} \mathrm{~S}$, is the absence of air or oxygen.

The high salinity will enhance galvanic corrosion processes where conductivity would otherwise limit the rate of corrosion. There is evidence from recent studies at SCE's subcontractor and at the Bureau of Mines that the very high salinity brines are not as bad as sea water in this regard. Further, chlorides are known ${ }^{(2)}$ to result in stress corrosion cracking of stainless steels and titanium. Such cracking of stainless steel was observed at Cerro Prieto. (3) All corrosion effects will be accelerated at the high temperature in the system. The presence of both $\mathrm{CO}_{2}$ and $\mathrm{H}_{2} \mathrm{~S}$ will tend to maintain the $\mathrm{pH}$ at less than neutral values while $\mathrm{NH}_{3}$ will tend to raise $\mathrm{pH}$ levels. At Sinclair No. 4 , the $\mathrm{CO}_{2}$ dominates and the $\mathrm{pH}$ is in the 3 to 5 range. In low $\mathrm{pH}$ brines, carbon steel and 
other materials readily attacked by acid will tend to be corroded. The hydrogen sulfide will attack carbon steel ${ }^{(4)}$ and copper alloys, resulting in corrosion through sulfide formation and sulfide catalyzed hydrogen embrittlement. Ammonia will cause corrosion of copper alloys. It should be noted that in the absence of oxygen, the rate of corrosion of carbon steel was found to be low at Cerro Prieto; thus, carbon steel may be a quite satisfactory material provided temperatures are low enough and oxygen is excluded. Special precautions will be necessary to prevent entry of air into utilization systems to prevent severe corrosion.

The role of the reducing environment on corrosion in geothermal process systems has not been investigated adequately. However, as evidenced by the low rate of corrosion of carbon steel at the Mexican Cerro Prieto operation, the effects appear to be quite significant. Corrosion ensuing from differential aeration will certainly not occur, though at low pH hydrogen evolution provides an alternative cathodic process to oxygen take-up. With steels, the initial formation of iron oxide is known to enhance the corrosive effect of sulfides; apparently exclusion of oxygen works to control this mechanism. Corrosion inhibition from protective iron oxide films will also not occur; however, the deposition of silica may reduce corrosion. This has been observed in handling water from hot spring in Iceland. (5) Also, this was observed in the well liner during the Pure Oil Company program in the Buttes area. (6) The role of deposits of calcium silicate in this regard is likely to be similar.

The corrosion and corrosion-related problems anticipated in processing geothermal brines are summarized in a cause and effect relationship in Table 6.

While, as shown in the table, some beneficial effects (vis-a-vis an ordinary atmospheric environment) may be anticipated, the corrosion problems are likely to be more severe than those encountered in sea water desalination.

\section{(b) Pertinent Prior Testing}

Results from three sources are pertinent to the selection of corrosion resistant materials for high salinity, hot geothermal brine processing. These are (a) hot salt corrosion tests and related studies, (b) experience with a variety of laboratory tests and operating plants for sea water desalination, and (c) the experience at Cerro Prieto and at the various programs in the Buttes Area. 
TABLE 6

ANTICIPA TED CORROSION PROBLEMS

\begin{tabular}{|c|c|}
\hline Condition & Effect \\
\hline $\begin{array}{l}\text { Elevated temperatures (to } \\
700^{\circ} \mathrm{F} \text { ) }\end{array}$ & $\begin{array}{l}\text { Accelerated corrosion rates. } \\
\text { Alternate corrosion mechanisms not oper- } \\
\text { ating at lower temperatures. }\end{array}$ \\
\hline \multirow[t]{2}{*}{ No oxygen in brine } & $\begin{array}{l}\text { Reduces or eliminates formation of protec- } \\
\text { tive oxide films. }\end{array}$ \\
\hline & Requires alternate cathodic process(es). \\
\hline $\begin{array}{l}\text { Possible entry of air into } \\
\text { system }\end{array}$ & $\begin{array}{l}\text { Accelerated corrosion rates. } \\
\text { Possible protective oxide films }\end{array}$ \\
\hline \multirow[t]{2}{*}{ Acidic gases; $\mathrm{H}_{2} \mathrm{~S}$ and $\mathrm{CO}_{2}$} & $\begin{array}{l}\text { Low } \mathrm{pH} \text { favors } \mathrm{H}_{2} \text { evolution and hydrogen } \\
\text { embrittlement }\end{array}$ \\
\hline & $\begin{array}{l}\text { Formation of sulfides. Sulfide catalyzed } \\
\text { embrittlement of ferritic and martensitic } \\
\text { steels. }\end{array}$ \\
\hline \multirow[t]{2}{*}{ Ammonia present } & $\begin{array}{l}\text { Stress corrosion cracking of } \mathrm{Cu} \text { and } \\
\text { alloys }\end{array}$ \\
\hline & $\begin{array}{l}\text { Complexing; enhanced corrosion of } \mathrm{Cu}, \mathrm{Ni} \\
\mathrm{Zn} \text { and possibly other metals }\end{array}$ \\
\hline Sand in producing structure & $\begin{array}{l}\text { Possible erosion; accelerated corrosion } \\
\text { through loss of protective films by erosion }\end{array}$ \\
\hline \multirow[t]{2}{*}{ Silica dissolved in brine } & May deposit protective coating on cooling \\
\hline & $\begin{array}{l}\text { Deposition at flashing region (only) may } \\
\text { lead to crevice corrosion }\end{array}$ \\
\hline \multirow[t]{2}{*}{ High salinity } & Electrolyte for corrosion processes. \\
\hline & $\begin{array}{l}\text { May deposit on cooling for flashing; may } \\
\text { cause crevice or other corrosion process }\end{array}$ \\
\hline High chloride content & $\begin{array}{l}\text { Stress corrosion cracking of austenitic } \\
\text { stainless steels in presence of oxygen }\end{array}$ \\
\hline
\end{tabular}

*Based on hot salt corrosion tests, the role of protective oxide films is expected to be minimal. 
The experience and economic evaluation of the Mexicans at Cerro Prieto indicate that carbon steel is the most cost effective construction material for for all parts of the system. Very little corrosion of carbon-steel parts exposed to brine or vapor has occurred unless air (oxygen) was present. The most severe corrosion has been encountered at the tops of the silencer vessels where convection currents carry air to the interior. Erosion has not been a problem except when a well is first started up. When this occurs, the initial product brine contains particles of sand from the producing formation and this causes slight erosion of the high pressure separator wall at the point of feed entry. The only stainless steelused in the system is a rupture disc; corrosion has been observed on this component (probably chloride-induced stress corrosion). It should be noted that the temperature and salinity of their brines are lower than those of the brines in the Buttes Area of the Imperial Valley. Corrosion problems can be expected to be more severe in processing the Imperial Valley brines.

Hot salt corrosion( $7-9)$ involves elevated temperatures and no bulk water; salt vapor and molten salt electrolyte are often encountered. While the conditions are significantly different than those encountered in processing geothermal brines; there are some lessons to be learned. First, oxide films are not usually protective in the hot salt environmentand may not be so in geothermal brines, thus, ordinarily corrosion-resistant metals are attacked. Second, the corrosion rate can be expected to be drastically increased in the presence of oxygen. Third, without applied stresses, refractory alloys may undergo uniform attack; with these stresses, intergranular and possibly transgranular attack may occur. Fourth, stress cracking may occur as a result of hydrogen embrittlement resulting from cathodic hydrogen evolution; this is more likely to occur in the absence of oxygen especially at the low $\mathrm{pH}$ levels produced by $\mathrm{H}_{2} \mathrm{~S}$ and $\mathrm{CO}_{2}$ in the geothermal brines. Hydrogen sulfide is known to catalyze the absorption of hydrogen by ferritic and martensitic steels, leading to embrittlement. Steels of greater than $17 \% \mathrm{Cr}$ are resistant to this form of attack.

Corrosion in sea water and its concentrates at temperatures up to $250^{\circ} \mathrm{F}$ has been studied extensively in connection with desalination by thermal processing. Some results to $400^{\circ} \mathrm{F}$ have been obtained for certain conditions of brine concentration, $\mathrm{pH}$, and gaseous environment in the evaluation of new alloys and protective coatings. 
Mild and low alloy steels, stainless steels, copper and copper alloys, aluminum alloys, and titanium and its alloys have all been tested and used in various desalination plants and pilot plants with varying degrees of freedom from corrosion. Recent $R \& D$ projects at the Office of Saline Water actively explored both new and old alloys to identify low-cost materials which can give satisfactory service in sea water distillation plants. (10) Guidance in selection of metals for geothermal brine processing can also come from these studies.

The critical role of oxygen content is clearly evident from these results. Oxygen content must be essentially zero (below a few ppb) to inhibit corrosion processes where oxygen is the cathodic depolarizer. This effect of oxygen is expected to be even more critical at the higher geothermal brine temperatures. While the problems with uniform corrosion attack are expected to be enhanced by the presence of higher temperatures coupled with $\mathrm{H}_{2} \mathrm{~S}, \mathrm{CO}_{2}$, and $\mathrm{NH}_{3}$, the corrosion behavior of these various metals and alloys at the lower temperatures used for sea water processing can serve as guides to selection of candidate materials and to the interpretation of test results.

\section{(c) Prevention of Corrosion}

In dealing with brine-caused corrosion, there is little which can be done to remove the agents (salts, $\mathrm{H}_{2} \mathrm{~S}$, etc.) which cause corrosion. Excluding air (oxygen) should minimize many effects. The major approach to prevention of corrosion is the use of selected corrosion resistant materials. In the low temperature end of a commercial plant, for example, low cost plastics can be widely used. More expensive metal claddings can be used where necessary in high temperature regions. Specifically, corrosion-resistant materials can be specified for critical parts and organic coatings can be considered for certain surfaces (e.g., the interior walls at the flash vessels). Special alloys or galvanized iron can also be considered for some components such as condenser tubing. The cost of galvanization is relatively low, compared to stainless-steel tubing, for example, and although it cannot be expected to provide permanent protection, it can certainly improve resistance to corrosion by the cooling water and may also reduce attack by the condensing vapors. However, carryover of ammonia in the condensing steam which could lead to complexing and removal of the $\mathrm{Zn}$ coating must be considered prior to choosing galvanized piping. It is reported that Mexico plans to use galvanized iron pipes as condensers for a plant to produce 
potable water from steam flashed from geothermal brine. In the Cerro Prieto design, the vapor is condensed inside the tubes while cooling water (brackish) flows over the outside of the tubes which are located at the base of a cooling tower. If sea water (or other high salinity water) is used for coolant in the power plant, potential corrosion from the coolant side may govern the selection of tube material although the presence of ammonia in the condensate, if not previously removed, may render the usual sea water solution (copper nickel) unacceptable. Austenitic stainless steels will generally be avoided for stressed components which may be exposed to air because of their tendency for stress corrosion cracking in the presence of chloride ions. It should be noted that the deposition of silica on the internal surfaces of metal equipment can actually make the system less subject to corrosion than would otherwise be expected. (5)

The selection of the appropriate materials for each system component will require both laboratory and field testing under well operating conditions so that the optimum materials can be reliably determined. However, the corrosion studies directly applicable to the utilization of high salinity brines already completed will serve to accelerate the proposed corrosion studies and result in a rapid, reliable selection of critical pilot plant materials.

\section{d. Power Cycles}

A number of power cycles have been proposed for extracting thermal energy from the geothermal resources of the Salton Sea KGRA. Differences in the processes result from attempts to increase efficiency, reduce cost, or avoid one or another of the severe corrosion, erosion, and solids depositions problems associated with processing the high salinity brines of the Salton Sea KGRA. A preliminary screening of a number of alternate approaches to power generation was conducted under the Participants' funded, Phase O Program to evaluate the merits of these various proposed systems. A comparative assessment was made with respect to thermodynamic performance, current development problems, economics, and potential for future growth. The results of this cycle assessment study are described in detail in Appendix B of this proposal. The objective of the cycle study was to reduce the number of system concepts to a relatively small number, which can be examined in greater detail in a follow-on study after field tests have been performed. In this manner, final selection of the concept most suitable to the specific Salton Sea KGRA geothermal brines can be made. 
TABLE 7

SUMMARY OF CYCLE STUDIES

(Power Production from $3 \times 10^{6} \mathrm{lb} / \mathrm{hr}$ Well Flow)

\begin{tabular}{|c|c|c|c|c|c|c|c|}
\hline \multirow{2}{*}{ Cycle } & \multicolumn{3}{|c|}{$\begin{array}{c}\text { Gross Generator Output } \\
\text { (MW) }\end{array}$} & \multirow{2}{*}{$\begin{array}{c}\text { Feedwater } \\
\text { Pump } \\
\text { Power } \\
\text { (MW) }\end{array}$} & \multirow{2}{*}{$\begin{array}{c}\text { Relative } \\
\text { Power } \\
\text { Production } \\
\text { Capability }\end{array}$} & \multirow{2}{*}{$\begin{array}{c}\text { Corrosion } \\
\text { Erosion } \\
\text { Scaling } \\
\text { Problems }\end{array}$} & \multirow{2}{*}{$\begin{array}{c}\text { Near-Term } \\
\text { Development } \\
\text { Potential }\end{array}$} \\
\hline & l Stage & 2 Stage & 3 Stage & & & & \\
\hline Direct Steam, Wet Tower & 42.9 & 49.0 & 54.7 & 0 & 1.0 & High & High \\
\hline Direct Steam, Dry Tower & 34.6 & 41.0 & 45.8 & 0 & 0.83 & High & High \\
\hline Steam-to-Steam, Wet Tower & 35.0 & 42.9 & 47.0 & 0.14 & 0.86 & Moderately High & Good \\
\hline Steam-to-Steam, Dry Tower & 30.2 & 37.4 & 41.3 & 0.14 & 0.75 & Moderately High & Good \\
\hline $\begin{array}{l}\text { Steam-to-Isobutane, } \\
600 \text {-psi system }\end{array}$ & - & 38.0 & 42.0 & 5.4 & 0.67 & Moderately High & Moderate \\
\hline $\begin{array}{l}\text { Steam-to-Isobutane, } \\
1050 \text {-psia system }\end{array}$ & - & - & 49.0 & 10.0 & 0.71 & Moderately High & Moderate \\
\hline Steam-to-N butane & 30.6 & - & - & 2.4 & 0.51 & Moderately High & Moderate \\
\hline Steam-to-Freon 114 & 30.8 & - & - & 5.8 & 0.46 & Moderately High & Moderate \\
\hline Steam-to-A mmonia & 27.0 & - & - & 3.8 & 0.42 & Moderately High & Moderate \\
\hline \multirow[t]{2}{*}{ Total Flow Concept* } & \multicolumn{3}{|c|}{$\begin{array}{r}62.0^{*}(90 \% \text { turbine } \\
\text { efficiency) }\end{array}$} & 0 & 1.13 & Very High & Low \\
\hline & \multicolumn{3}{|c|}{$\begin{aligned} & 57.0^{*}(85 \% \text { turbine } \\
&\text { efficiency })\end{aligned}$} & 0 & 1.04 & Very High & Low \\
\hline
\end{tabular}

* This concept involves continuous rather than staged flashing.

A tabulation of the various power options which were considered in the Phase O study for power production is given in Table 7. The table summarizes relative power production capabilities of the various concepts and rates each concept with respect to technical problems and development potential. Table 8 gives a detailed comparison of those design features of the proposed concepts which are germane to capital, operating, and development costs, and assesses the potential of the concepts for successful near-term development. The evaluation considers corrosion, erosion, and scaling problems; the complexity of the process system; and the state of the art of actual component hardware. The table assigns a priority rating to those options which are recommended for more detailed consideration. The first four cycle options offer the greatest promise for application to the proposed Salton Sea pilot plant. In order of preference, the recommended options are the following:

1) Steam turbine operating on steam from the flashed brine

2) Steam turbine operating on clean steam generated by a secondary flashed steam-to-water heat transfer system 
TABLE 8

COMPARISON OF ALTERNATIVE GEOTHERMAL POWER OPTIONS

(Sheet 1 of 2)

\begin{tabular}{|c|c|c|c|}
\hline Option & Advantages & Disadvantages & Development Potential \\
\hline $\begin{array}{l}\text { 1. Steam turbine opera- } \\
\text { ting on steam flashed } \\
\text { from the brine. }\end{array}$ & $\begin{array}{l}\text { Simplest flow arrangements. } \\
\text { High cycle efficiency. Low } \\
\text { capital cost. Flash evapora- } \\
\text { tors less susceptible to brine } \\
\text { fouling and corrosion than } \\
\text { heat exchanger surfaces. } \\
\text {. }\end{array}$ & $\begin{array}{l}\text { Additional steam purification equipment } \\
\text { required to protect turbine from cor- } \\
\text { rosion and deposition. Turbine design } \\
\text { modifications may be required to ac- } \\
\text { commodate impurities in the steam. } \\
\text { Multi-flash staging requires a multi- } \\
\text { stage admission turbine. }\end{array}$ & $\begin{array}{l}\text { High development potential with } \\
\text { low development risks. }\end{array}$ \\
\hline $\begin{array}{l}\text { 2. Steam turbine opera- } \\
\text { ting on clean steam } \\
\text { generated by a second- } \\
\text { ary brine-to-steam } \\
\text { heat transfer system. }\end{array}$ & $\begin{array}{l}\text { Turbine sees only clean } \\
\text { steam. Conventional steam } \\
\text { cleanup equipment is } \\
\text { adequate. }\end{array}$ & $\begin{array}{l}\text { Fouling and corrosion presents a prob- } \\
\text { lem in tubular steam generator. Lower } \\
\text { turbine throttle temperature and pres- } \\
\text { sure than Option l. Increased capital } \\
\text { cost due to secondary steam generator } \\
\text { loop. Surface condenser required. } \\
\text { Larger capital cost and lower power } \\
\text { capability than Option } 1 \text {. }\end{array}$ & $\begin{array}{l}\text { High development potential with } \\
\text { low development risk. Develop- } \\
\text { ment risk is probably lower than } \\
\text { Option l,but economics are less } \\
\text { favorable. }\end{array}$ \\
\hline $\begin{array}{l}\text { 3. Isobutane turbine, } \\
\text { flashed steam to iso- } \\
\text { butane heat transfer } \\
\text { system. }\end{array}$ & $\begin{array}{l}\text { Potentially smaller (and } \\
\text { lower cost) turbine than } \\
\text { steam cycles. }\end{array}$ & $\begin{array}{l}\text { All of Option } 2 \text { (except turbine throttle } \\
\text { press) plus: Larger steam generators } \\
\text { due to poor thermal conductivity of } \\
\text { isobutane. Large isobutane pumps } \\
\text { and pump power. High working pres- } \\
\text { sures increase heat exchanger costs. } \\
\text { Development of large secondary fluid } \\
\text { turbine required. }\end{array}$ & $\begin{array}{l}\text { Has all of the development prob- } \\
\text { lems of Option } 2 \text { plus unavail- } \\
\text { ability of isobutane turbines in the } \\
\text { desired size range. }\end{array}$ \\
\hline $\begin{array}{l}\text { 4. Nutane turbine, } \\
\text { flashed steam-to-N- } \\
\text { butane heat transfer } \\
\text { system. }\end{array}$ & $\begin{array}{l}\text { Potentially smaller turbine } \\
\text { than steam cycles. }\end{array}$ & $\begin{array}{l}\text { All of Option } 3 \text { plus lower power } \\
\text { capability. }\end{array}$ & Low \\
\hline $\begin{array}{l}\text { 5. Freon-turbine, } \\
\text { flashed steam-to- } \\
\text { freon heat transfer } \\
\text { system. }\end{array}$ & $\begin{array}{l}\text { Potentially smaller turbine } \\
\text { than butane or steam } \\
\text { cycles. }\end{array}$ & $\begin{array}{l}\text { All of Option } 3 \text {. Freon decomposition } \\
\text { may lead to corrosion. }\end{array}$ & Low \\
\hline $\begin{array}{l}\text { 6. Ammonia turbine, } \\
\text { flashed steam-to- } \\
\text { ammonia heat trans- } \\
\text { fer system. }\end{array}$ & Potentially smallest turbine. & All of Option 3. & Low \\
\hline 7. Total flow concept. & $\begin{array}{l}\text { Eliminates separators flash } \\
\text { evaporators and steam gen- } \\
\text { erators. Uses rugged turbo- } \\
\text { machinery with replaceable } \\
\text { parts. High efficiency. Po- } \\
\text { tentially a simple, low cost } \\
\text { system. }\end{array}$ & $\begin{array}{l}\text { More severe corrosion/erosion foul- } \\
\text { ing problems than Options } 1 \text { and } 2 \text {. } \\
\text { Requires development of novel turbo- } \\
\text { machinery concepts and development } \\
\text { of basic analysis methods for high- } \\
\text { velocity, two-phase brine flow. }\end{array}$ & $\begin{array}{l}\text { Development potential uncertain. } \\
\text { Requires further analytical } \\
\text { evaluation. }\end{array}$ \\
\hline
\end{tabular}


TABLE 8

\section{COMPARISON OF ALTERNATIVE GEOTHERMAL POWER OPTIONS} (Sheet 2 of 2 )

\begin{tabular}{|c|c|c|c|}
\hline Óption & Advantages & Disadvantages & Development Potential \\
\hline $\begin{array}{l}\text { 8. Is obutane turbine, } \\
\text { flashed steam-to- } \\
\text { is obutane plus brine- } \\
\text { to-isobutane heat } \\
\text { exchangers. }\end{array}$ & $\begin{array}{l}\text { Relatively simple flow ar- } \\
\text { rangement, single flash ves- } \\
\text { sel and no downhole pump. }\end{array}$ & $\begin{array}{l}\text { All of Option } 3 \text { plus scale deposition } \\
\text { on tubes of brine heat exchanger. }\end{array}$ & $\begin{array}{l}\text { Low development potential due to } \\
\text { scale deposition problems. }\end{array}$ \\
\hline $\begin{array}{l}\text { 9. Is obutane turbine and } \\
\text { downhole pump, total } \\
\text { well flow to isobutane } \\
\text { heat transfer system. }\end{array}$ & $\begin{array}{l}\text { Simple flow arrangement, } \\
\text { steam separator not re- } \\
\text { quired. High efficiency } \\
\text { possible. Scale deposi- } \\
\text { tion in well is minimized. }\end{array}$ & $\begin{array}{l}\text { All of Option } 3 \text { plus scale deposition } \\
\text { on heat exchanger tubes. Large ex- } \\
\text { pensive alloy heat exchanger re- } \\
\text { quired due to low coefficients and } \\
\text { corrosiveness of brine. }\end{array}$ & $\begin{array}{l}\text { Low development potential due } \\
\text { to scale deposition problems. }\end{array}$ \\
\hline $\begin{array}{l}\text { 10. Downhole heat } \\
\text { exchanger }\end{array}$ & $\begin{array}{l}\text { Turbine sees only clean } \\
\text { steam. May ease heat ex- } \\
\text { changer corrosion and } \\
\text { fouling problems. }\end{array}$ & $\begin{array}{l}\text { Thermal refluxing problem with con- } \\
\text { centric tube in well casing, i. e. } \\
\text { cold downstream must be thermally } \\
\text { insulated from hot upstream. Uncer- } \\
\text { tain knowledge of heat extraction } \\
\text { mechanism from geothermal deposits } \\
\text { Outside scaling of casing and plugging } \\
\text { of formation may be a problem. }\end{array}$ & $\begin{array}{l}\text { Development potential is uncertain. } \\
\text { Further analysis is required. }\end{array}$ \\
\hline $\begin{array}{l}\text { 11. Inject hydrocarbon } \\
\text { into hot brine and } \\
\text { pass vapor to mixed } \\
\text { vapor turbine }\end{array}$ & $\begin{array}{l}\text { Simple flow arrangement. } \\
\text { Higher hydrocarbon temp- } \\
\text { erature than } 3 \text {. May ease } \\
\text { well casing corrosion } \\
\text { and/or scale deposition } \\
\text { problems. }\end{array}$ & $\begin{array}{l}\text { Removal of brine droplets from mixed } \\
\text { hydrocarbon-steam vapor presents } \\
\text { purification problems. Thermal re- } \\
\text { fluxing in well. Larger fluid flow re- } \\
\text { quirements in well. Requires special } \\
\text { turbine development. Loss of hydro- } \\
\text { carbon with brine, condensate, and } \\
\text { noncondensible gas streams. }\end{array}$ & $\begin{array}{l}\text { Requires further evaluation to } \\
\text { establish development potential. }\end{array}$ \\
\hline
\end{tabular}


3) Isobutane turbine with a steam-to-isobutane heat transfer system

4) Total flow concept in which the saturated brine solution is expanded to high velocity through a converging-diverging nozzle and then is used to drive a hydraulic impulse turbine

5) Isobutane turbine with a brine-to-isobutane heat transfer system

6) Down-hole heat exchanger

7) Down-hole, direct-contacting hydrocarbon vapor generation with mixed vapor turbine

Conventional steam systems have the least development risks and therefore the highest probability for successful near-term development, and in addition, have equal or higher performance capabilities than any of the proposed binary cycle concepts. The isobutane cycle involving heat exchange with flashed steam does not show a significant performance advantage over the steam systems and it involves a higher development risk. A more detailed evaluation of economics and thermohydraulic performance factors may make this option appear more favorable. The total flow concept has the potential for achieving high thermodynamic performance with simple, low-cost turbomachinery, if the potential scaling problems can be resolved. This concept does not require any brine-tosteam heat transfer equipment. The isobutane systems involving heat exchange with the brine do not appear promising due to the problem of scale formation on heat exchanger tubes which will be very difficult to resolve or design around. The down-hole heat exchanger and hydrocarbon vapor generation have technical difficulties and high costs associated with developing the concepts and proving their performance capabilities.

Except for the total flow concept, the direct steam system show the highest performance potential. Next in order of performance is the steam-to-steam binary cycle, this system is followed by the steam-to-isobutane cycle $\left(380^{\circ} \mathrm{F}\right.$, $1050 \mathrm{psia})$. Although the latter system shows a somewhat lower efficiency, a developed isobutane expander could be appreciably lower in cost than a low pressure steam turbine operating over the same temperature range because of the much smaller volume of isobutane vapor involved. However, the costs of isobutane handling equipment such as pumps and vessels would add to isobutane cycle costs. 
Theoretically, the total flow concept has a higher performance capability because it involves continuous rather than stepwise flashing of the brine and expansion of the flashed steam. In view of its design simplicity, it could also be a very low capital cost system. However, this concept requires the extensive and long-term development of new and novel turbomachinery and may have more serious corrosion, erosion, and scaling problems than those associated with direct and binary systems. Progress on the development of this system at the Lawrence Livermore and Jet Propulsion Laboratories and on development of possibly applicable prime movers such as the hydroexpander will be closely monitored for factoring into the final selection of the optimum power cycle for the pilot plant. However, it is anticipated at this time that the total flow concept will not be fully developed in time to be utilized in the planned pilot plant. The pilot plant will most likely employ a more conventional technology such as a direct steam or binary cycle.

In summary, power cycle studies have been carried out to evaluate promising concepts applicable to the high salinity Imperial Valley brines. Two power cycles appear to be especially applicable to near-term, electric power generation; multistage direct flash steam cycle or the flashed steam-to-binary cycle. A more detailed study based upon results of field tests of power generation components will be used to make a final cycle selection for the pilot plant. The completed preliminary power cycle studies will be a major factor in accelerating requisite technology development activities and final power cycle selection leading to an early and successful pilot plant operation.

\section{e. Mineral Recovery}

Hazen Research Inc. has been actively involved with minerals recovery from geothermal fluids through participation with the U.S. Department of Interior, Bureau of Mines, under Contracts SO 133084 and HO 144104 for geothermal fluids in general and with Southern Pacific Land Co. for the Salton Sea geothermal fluids.

Past work done at Sinclair No. 4 has shown that flashing of the geothermal brine to generate steam results in a lowering of the temperature of the brine to a level where the brine becomes supersaturated with silica $\left(\mathrm{SiO}_{2}\right)$ and ferrous hydroxide $\left[\mathrm{Fe}(\mathrm{OH})_{2}\right]$. This supersaturation leads to precipitation of these components and scale deposition on pipelines and process equipment. 
Control of precipitation, by stage-wise control of brine pH, results in essentially complete removal of $\mathrm{SiO}_{2}$ followed by $\mathrm{Fe}(\mathrm{OH})_{2}$. Thus, two of the constituents of Salton Sea KGRA brines can be removed rather simply by $\mathrm{pH}$ control, yielding a valuable product, iron hydroxide, and removing scale-forming constituents from the brine.

Eurther adjustment of brine $\mathrm{pH}$, together with air oxidation of the brine, results in essentially complete removal of manganese by precipitation as manganese dioxide $\left(\mathrm{MnO}_{2}\right)$, thus yielding another valuable product.

Proper control of operating conditions during precipitation of iron and manganese will result in the coprecipitation of some or all of the lead and zinc values in the Salton Sea KGRA brine. One of the purposes of the proposed minerals recovery experimental plant would be to further define and quantify the extent to which lead and zinc can be recovered.

Following removal of manganese from the Salton Sea KGRA brine, a number of process alternatives are available for recovering other minerals. These are:

1) Concentration of the brine followed by precipitation of barium and strontium salts. - This approach requires significant amounts of energy to remove water from the brine. Solar evaporation would be a low-energy means of concentration, but the required land area is probably not available in the Salton Sea-Imperial Valley area.

2) Concentrations of the brine followed by crystallization of sodium chloride ( $\mathrm{NaCl}$-common salt) and potassium chlorida ( $\mathrm{KCl}$-potash fertilizer). - This approach also requires the expenditure of significant amounts of energy to remove water. In addition, the economics of $\mathrm{NaCl}$ and $\mathrm{KCl}$ recovery in this geographic location do not appear to be favorable.

3) Removal of lithium values from the brine by $\mathrm{pH}$ control and addition of lithium-selective precipitating reagents. - This approach requires the expenditure of very little energy since no evaporation of water is involved. It also recovers a relatively high-value element, lithium.

The Salton Sea KGRA has the potential of becoming the world's largest lithium resource and hence could contribute significantly to the economic viability of power generation from Salton Sea KGRA brines. 
Therefore, lithium recovery from these brines was selected for process study and evaluation in the proposed minerals recovery experimental plant.

Hazen has prepared the enclosed preliminary flowsheet (Figure 5) for. minerals recovery from Sinclair No.4 type brines of the Salton Sea KGRA. As explained above, the mineral recovery system is designed to process $10 \mathrm{gpm}$ of post-flash brine for the recovery of iron, manganese, lead, zinc, and lithium.

Briefly, the process begins with a chemical treatment step for nearly complete removal of scale-forming components from Sinclair No. 4 brine. This process utilizes a partial neutralization of the pre-flash Sinclair No. 4 brine (probably with ammonia) to remove most of the dissolved silica, together with some aluminum [as $\left.\mathrm{Al}(\mathrm{OH})_{3}\right]$ and iron [as $\left.\mathrm{Fe}(\mathrm{OH})_{2}\right]$. Following flashdown of the so-treated Sinclair No.4 brine, the precipitated materials are removed from the post-flash brine via a thickener in the first stage of the mineral recovery experimenal plant.

Clarified brine is then fed into a secondary reactor, together with calcium hydroxide slurry, for removal of the remaining iron and silica content. Sufficient provisions have been included in the flowsheet to allow recycle of any of the various precipitated solids back to the initial partial neutralization reactor for seeding-nucleating purposes, should this prove to be necessary or desirable.

Any remaining iron and silica precipitate is removed via another thickener tank and the clarified brine is transferred to the manganese recovery step.

Manganese is recovered as either manganese hydroxide $\left[\mathrm{Mn}(\mathrm{OH})_{2}\right]$ or as manganese dioxide $\left(\mathrm{MnO}_{2}\right)$ from the iron-free Sinclair No. 4 brine by further alkalizing to a $\mathrm{pH}$ of about 8. Air oxidation of the resulting manganous hydroxide precipitate can be utilized to yield manganese dioxide, if desired.

Following separation of the manganous hydroxide or manganese dioxide solids from the brine, the clarified brine advances to surge tankage and thence into the lithium recovery area.

Lithium is recovered as the aluminate from the clarified brine using aluminum chloride solution as the precipitating reagent. Lithium precipitates essentially quantitatively as a compound $\left(\mathrm{Li}_{2} \cdot 2 \mathrm{Al}_{2} \mathrm{O}_{3}\right)$. This precipitate also scavenges or removes all other suspended matter from the brine, thus ensuring its clarity for reinjection into Sinclair No. 3 well. 
TABLE 9

ANTICIPATED MINERALS PRODUCTION FROM

10-gpm FACILITY

\begin{tabular}{|c|c|}
\hline & $\begin{array}{l}\text { Production Rate } \\
\text { (lb/hr) }\end{array}$ \\
\hline $\begin{array}{l}\text { A mmonia } \mathrm{NH}_{3} \text { (as } \mathrm{NH}_{4} \mathrm{OH} \\
\text { solution) }\end{array}$ & 1.7 as $\mathrm{NH}_{3}$ \\
\hline Manganese Hydroxide, $\mathrm{Mn}(\mathrm{ON})_{2}$ & 12 \\
\hline Ferrous Hydroxide, $\mathrm{Fe}(\mathrm{OH})_{2}$ & 16 \\
\hline Aluminum Hydroxide, $\mathrm{Al}(\mathrm{OH})_{3}$ & 7 \\
\hline Silica, $\mathrm{SiO}_{2} \cdot \mathrm{XH}_{2} \mathrm{O}$ & 7 \\
\hline Lithium Aluminate, $\mathrm{Li}_{2} \mathrm{O} \cdot 2 \mathrm{H}_{2} \mathrm{O}_{3}$ & 35 \\
\hline $\begin{array}{l}\text { Zinc (coprecipitated with iron and } \\
\text { manganese) }\end{array}$ & 1.5 \\
\hline $\begin{array}{l}\text { Variable quantity of calcium car- } \\
\text { bonate depending upon reaction } \\
\text { conditions }\end{array}$ & \\
\hline
\end{tabular}

Ongoing research would be directed toward recovery of lithium, as lithium carbonate or hydroxide, from the lithium aluminate precipitate and recycling of the aluminum values back to the lithium precipitation step to minimize make-up aluminum requirements.

All process vessels will be covered and connected into a common vent header system maintained at a slight negative pressure. Vent gases are fed into a two-stage, counter-flow scrubbing tower system to recover ammonia gas, both that originally present in the Sinclair No. 4 brine (approximately $500 \mathrm{ppm}$ ) and that ammonia which may be added to partially neutralize the raw Sinclair No.4 brine and remove the scale-forming components therefrom.

Anticipated production of minerals from Sinclair No. 4 post-flash brine is as shown in Table 9.

Phase O on-site process work by SPL has shown that brine composition will change with time, in some cases trending upward and in others, downward. For example, over the past year of test work, the fluoride content of the brine 


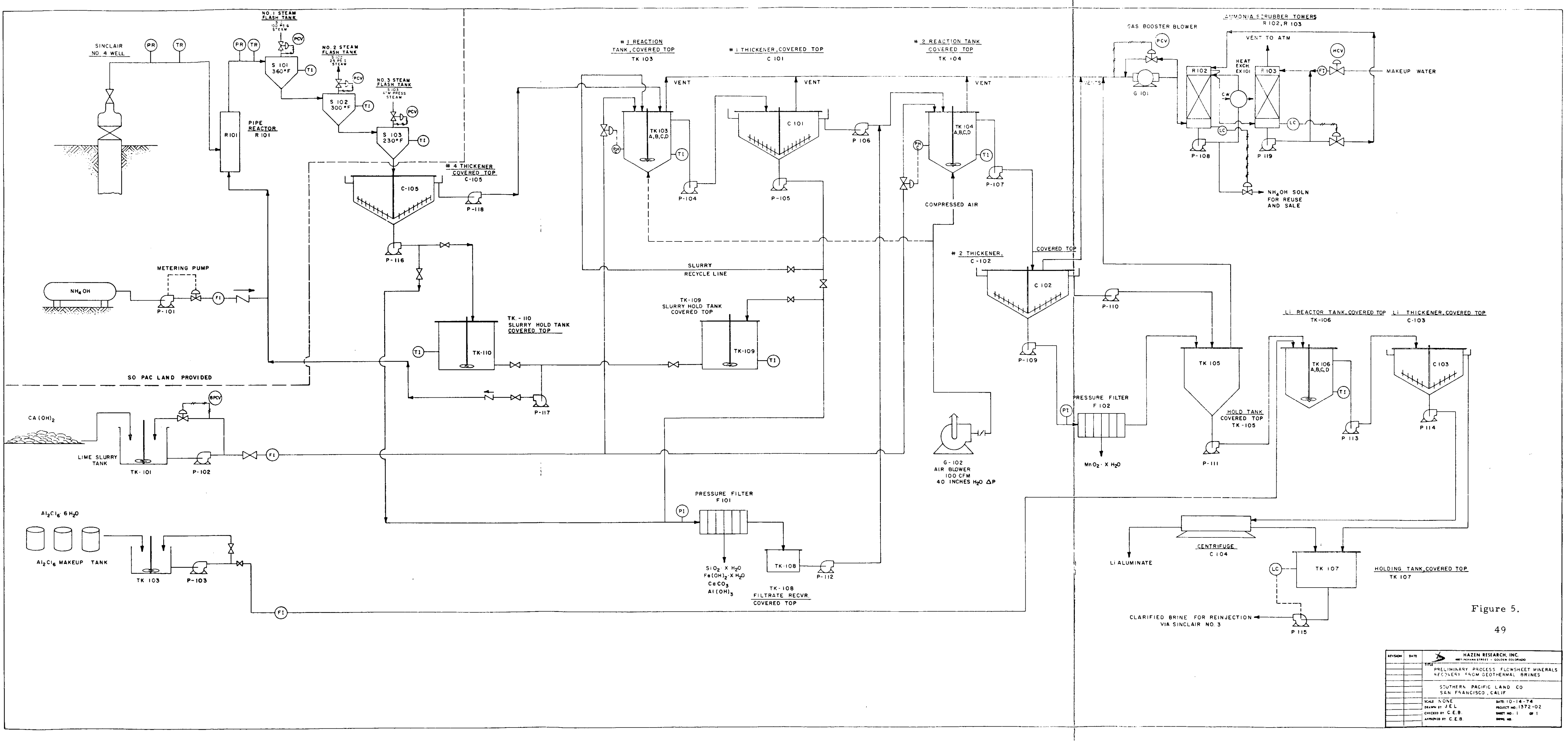




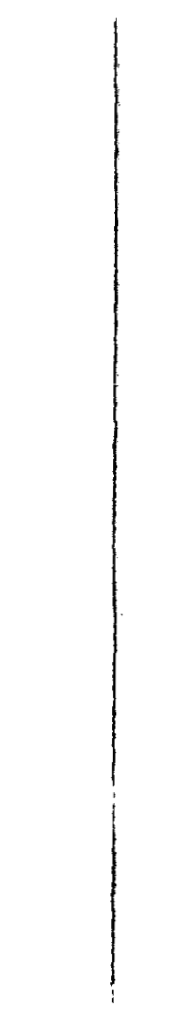


has apparently decreased from the 500-ppm range down to 5 to $7 \mathrm{ppm}$.

In view of the possible wide excursions of composition that can be expected with the geothermal brine, considerable flexibility and versatility has been designed into the proposed pilot plant flowsheet. Particularly, thickeners are oversized, in some cases as much as threefold, to provide extra surge and setting capacity should it be required.

In summary, work which has been completed under Bureau of Mines and private sponsorship has resulted in a process flow design for mineral recovery from Sinclair No. 4. The fact that this conceptual design has been completed will act to accelerate the successful completion of an experimental mineral recovery plant in the Salton Sea KGRA.

Knowledge acquired in the course of managing such a resource, and learning to cope with the extreme corrosivity and scaling tendencies of this geothermal fluid in mineral recovery process equipment should be applicable in many geothermal areas of the United States and of the world.

\section{f. Reservoir Assessment and Production}

Reservoir assessment work completed to date by investigators such as Helgeson indicates that the Salton Sea KGRA is a vast resource of high energy geothermal brine. Results of well flow tests conducted by Shell Oil Company and Morton Salt Company in the 1960's have been reviewed by PPC. In addition, the Participants conducted three well flow tests of Sinclair No. 4 totaling about 5 months. The knowledge gained through interpretation of this past work, along with well flow tests conducted during the Phase O Program have resulted in a much improved understanding of the Salton Sea KGRA resource base.

The program team is quite confident that sufficient high energy geothermal brine exists in the Salton Sea KGRA for hundreds of megawatts of geothermalelectric power production for many years. Based on this opinion, additional efforts at predicting the size of the reservoir are not needed prior to proceeding with a $10 \mathrm{MWe}$ pilot plant. However, additional reservoir assessment activities are expected to be carried out through the Area Resource Test Facility to define the size of the Salton Sea KGRA so that an estimate of the ultimate electric power production capability of the resource can be made. 
In contrast to the confidence as to reservoir adequacy for a follow-on pilot plant, it remains to be shwon whether or not Salton Sea KGRA brines can be successfully produced, handled, and injected on a long-term basis. Therefore, the main thrust of the proposed Phase 1 Program efforts will be to design a reliable production and injection system for the proposed Phase 2 Pilot Geothermal Utilization Facility.

As mentioned above, Sinclair No. 4 well was successfully flowed for about five months during the privately funded Phase $O$. The fact that the well has been flowed will act to accelerate the implementation of the proposed program because many of the operational problems which occur when wells are initially flowed have been solved.

\section{g. Environmental Impact Assessment}

The proposed facility offers many advantages for assessing the environmental impacts of geothermal resource development in the Salton Sea KGRA because it provides the worst case example in some respects. The brines are among the hottest and the most saline. Also, the test wells are situated within working proximity to representative areas of almost the total variety of biological systems found in the region: Irrigated agricultural land; disturbed, managed, and natural terrestrial habitats in wildlife refuges; and drainage, marsh, and lake aquatic habitats associated with the Salton Sea.

The test conditions will allow identification of potentially hazardous components of effluents while the small volumes of these materials are contained or effectively dispersed within the site of the experimental facility. Smallscale discharge and storage areas already exist whe re movement of contaminants into the environment can be detected and the effect on soil, water, and subsequent biota assessed with minimum further release of effluents.

Although the test wells are sited in close proximity to the Salton Sea National Waterfowl Wildlife Refuge, little quantitative information is available on any of the agricultural or natural biological systems in the area. Publications of the Bureau of Sports Fisheries and Wildlife of the U.S. Department of the Interior and California State Fish and Game provide only the estimates of use by game species of water fowl. These estimates indicate that 50,000 ducks and 35,000 geese overwinter in the Salton Sea refuges. Lists of vertebrate 
species recorded in the area are also available from these sources and indicate the presence of 230 species of birds, 51 species of mammals, 19 species of reptiles, 6 species of amphibians, and 14 species of fish. Included are one rare and one endangered species of birds--the California Black Rail (Latterallus jamaiconsis coturniculus) and the Yuma Clapper Rail (Rallus longirostris yumanensis), respectively. There are no available data on the abundance of any of these species or their relationship to any set of environmental conditions. Lists of common plants of the refuge are also included but no indication of salt, moisture, or temperature tolerances or relative abundance under differing environmental conditions are presented.

Most of the area is already under some form of environmental management and the California State Fish and Game area manager has reported concern with continued decline in the quality of natural habitats due to excess salts from agricultural waste water. Therefore, gradients in some forms of potential contaminants from geothermal development already exist and can be used in the development of predictive models.

\section{h. Area Resource Test Facility}

The attainment of economic geothermal brine utilization from water dominated systems will require extensive research and engineering investigations to resolve both known technological problem areas and problems which will arise in the course of power plant developments. An Area Resource Test Facility (ARTF) is proposed to provide the facilities for investigations in the disciplines related to commercial geothermal brine utilization.

The ARTF is intended to provide support to the technology development activity of the proposed program and to provide a field test facility for components and processes being developed by industry and government supported organizations for utilization of high temperature, high salinity geothermal brines. To the extent possible, the ARTF will be designed to facilitate relocation to other geothermal resource areas upon completion of its utility at the Salton Sea program site. Locating the ARTF in a high temperature, high salinity KGRA will allow the in situ utilization of well fluids having significant promise of commercial power generation. Testing of geothermal systems and components under development by various organizations is a necessary requirement for meaningful investigations. 
The ARTF will be designed to be supportive of research and engineering investigations in four major categories of effort: power generation; nonelectric uses; mineral recovery; and reservoir definition. For the purposes of this proposal, nonelectric uses would include uses of geothermal heat in areas other than power generation (e.g., fresh water, process heat).

The ARTF will be functionally organized into four primary sections: (1) reservoir assessment and engineering, (2) brine utilization components and process equipment testing, (3) instrumentation and controls testing and development, and (4) chemical and metallurgical analysis.

The Reservoir Engineering Section would contain equipment necessary to carry out basic geological measurements using core samples obtained during drilling operations. The measurements would include permeability, porosity, compressibility, grain density, conductivity, and natural radioactivity. Also included in this section would be equipment for reduction and interpretation of data obtained from field geologic explorations and land subsidence measurements.

The Brine Utilization Components and Process Equipment Testing Section would include facilities for (1) the study of fluid flow and heat and mass trans fer problems, particularly those associated with multiphase flow; (2) the testing of prime movers such as turbines, pumps, and ejectors; (3) the testing of process equipment for scale and corrosion control, heat exchangers, condensers, evaporators, separators, and scrubbers; (4) the testing of process equipment for nonelectric uses of geothermal energy; and (5) the testing of mineral recovery process equipment.

The Instrumentation and Controls Section would provide facilities for calibrations and the development of (1) flowrate measurement equipment; temperature and pressure instrumentation; (3) scale and corrosion monitoring equipment; (4) valves and controls systems; and (5) drilling instrumentation.

The Analytical Section would consist of facilities for (1) chemical analysis of brines, vapors, and solid precipitates; (2) metallurgical evaluations; and (3) environmental studies and monitoring.

The organization of the Area Resources Test Facility is summarized in Table 10 . 
TABLE 10

ORGANIZATION OF THE AREA RESOURCES TEST FACILITY

\begin{tabular}{|c|c|c|c|}
\hline $\begin{array}{l}\text { Reservoir } \\
\text { Engineering } \\
\quad \text { Section }\end{array}$ & $\begin{array}{c}\text { Components and } \\
\text { Process Equip- } \\
\text { ment Test } \\
\text { Section }\end{array}$ & $\begin{array}{c}\text { Instrumentation } \\
\text { and Control } \\
\text { Section }\end{array}$ & $\begin{array}{c}\text { Analytical } \\
\text { Section }\end{array}$ \\
\hline $\begin{array}{l}\text { Geochemistry } \\
\text { Geophysical } \\
\text { Measurement } \\
\text { Subsidence } \\
\text { Siting Analysis }\end{array}$ & $\begin{array}{l}\text { Fluid Flow } \\
\text { Heat-Mass } \\
\text { Transfer } \\
\text { Prime Movers } \\
\text { Evaporators - } \\
\text { Separators } \\
\text { Mineral } \\
\text { Recovery } \\
\text { Cooling Tower } \\
\text { Subsystems } \\
\text { Heat Exchangers } \\
\text { Scale-Corrosion } \\
\text { Process } \\
\text { Nonelectric Uses }\end{array}$ & $\begin{array}{l}\text { Flowrate } \\
\text { Measurement } \\
\text { Temperature and } \\
\text { Pressure } \\
\text { Instrumentation } \\
\text { Corrosion-Scale } \\
\text { Indicators } \\
\text { Valves-Controls } \\
\text { Drilling }\end{array}$ & $\begin{array}{l}\text { Chemical } \\
\text { Analysis } \\
\text { Environmental } \\
\text { Process } \\
\text { Development }\end{array}$ \\
\hline
\end{tabular}

Conceptually, the ARTF will consist of a building with adjoining test cells. The building will house the Reservoir Engineering Section, an analytical laboratory, the Instrumentation and Controls Section, a repair shop, tool room, offices, storage space; and personnel facilities. The test cells will be used for the conduct of investigations involving power plant and other brine utilization components and process equipment. Suitable handling equipment for heavy machinery will be provided. Geothermal well flow and cooling water will be piped to the ARTF. Part of the well flow will enter a flash separator to provide both liquid brine and steam for test purposes. The test cells and the analytical laboratory will contain instrumentation and recorders necessary for flowrate, pressure, and temperature measurements. For purposes of testing turbines, one of the test cells will include equipment such as ejectors, condenser, and generator for load simulation. 
The ARTF will have provisions for handling and conditioning the spent fluid prior to flow into the reinjection well.

In planning the ARTF, emphasis will be placed on considerations of both the type and size of equipment to be tested, and types of basic research to be conducted. Potential users from government agencies and private industry will be consulted to ensure proper facility design for maximum utility. 


\section{Program Description}

\section{a. Scope and Technical Objectives}

The objectives of the overall Salton Sea Geothermal Power Plant Program were discussed in Section I-A-2. The scope of the Phase 1 Program for which funding is requested includes the following:

- An assessment of the characteristics of the Salton Sea geothermal brines.

- The testing, evaluation, and selection of an economically, environmentally, and technically viable electric power generation cycle.

- The design, testing and evaluation of a mineral recovery experimental facility.

- Engineering studies and tests pertaining to the characterization and control of scaling, corrosion and erosion in brine handling facilities.

- Development and proof-testing of a reliable production and injection system, including a possible brine cleanup facility.

- Completion of a preliminary design and program plan for an experimental pilot geothermal power plant including mineral recovery if shown to be economic. The size of the pilot plant has been selected tentatively at $10 \mathrm{MWe}$.

- The evaluation, costing, design, and construction of an Area Resource Test Facility (ARTF) that can provide a field test site for proving out advanced components and processes for geothermal energy utilization.

\section{(1) Power Generation Subprogram}

The Power Generation Subprogram is divided into technology development, systems engineering, and environmental elements. The scope of the environmental evaluation will include the following:

1) Identify hazardous components of effluents.

2) Determine the present environmental conditions and the relationships between them and the existing biota and agricultural systems. 
3) Develop predictive models of the effect of release or storage of effluent on these systems.

4) Develop environmental and resource management programs (where power generation and mineral extraction processes allow) that will optimize environmental quality under commercial power production conditions.

5) Evaluate the alternative power generation processes in terms of environmental compatibility.

The scope of the technology development and systems engineering efforts is as follows:

1) Prepare an engineering analysis and an economic evaluation of candidate power generation cycles.

2) Investigate scale control concepts and evaluate material compatibility with the brine environment.

3) Test and evaluate preliminary power cycle components and measure effluent emissions from these component tests.

4) Design, fabricate, and test improved power production components.

5) Complete a cycle selection study by optimizing environmental, economic and technical analyses of candidate cycles.

6) Prepare an overall systems analysis of a geothermal-electric power plant. Assess the risks associated with omitting the pilot plant stage and going directly to a 50-MWe demonstration plant.

7) Prepare a preliminary design and cost estimate for the pilot (first) power plant employing the selected power generation cycle.

The major technical objective of the Phase 1 Power Generation Subprogram is to develop the technology which will allow construction of a follow -on experimental pilot geothermal power plant at the Salton Sea KGRA.

(2) Mineral Recovery Subprogram

The basic technical objective of the minerals recovery portion of the program is to demonstrate the feasibility and practicability of recovering the 
valuable mineral components from Salton Sea KGRA brines. In addition, it is planned to secure sufficient operating data to permit a realistic scale-up of both equipment requirements and capital and operating cost estimates.

In order to accomplish the subprogram objective stated above, a mineral recovery experimental plant will be designed, constructed, and operated. The plant would initially recover iron, manganese, and lithium as the valuable components of the brine, as well as removing the major scale-forming component, silica $\left(\mathrm{SiO}_{2}\right)$, therefrom.

It is believed that the total flow of geothermal fluid is suing from Sinclair No. 4 well may require treatment to remove scale-forming materials, since the only currently known effective method for disposal of spent brine is the injection of the brine underground via an existing well, Sinclair No. 3.

If the injected brine were to contain precipitable and scale-forming components such as silica and iron, it is possible that such constituents could plug off the pore spaces and flow channels in the subsurface structure of the injection well.

Therefore, it may be necessary to provide cleanup facilities for the total post-flash brine flow. The minerals recovery experimental plant can operate on a side-stream of this brine flow; i.e., $10 \mathrm{gpm}$ is deemed adequate to provide pilot plant design information in this area.

Should it be determined from the Reservoir Production Subprogram that injection of spent brine necessitates a brine cleanup system, such system would be designed, constructed, and operated as part of the Minerals Recovery Subprogram.

(3) Reservoir Production Subprogram

The Reservoir Subprogram is divided into two parts: Brine Production and Injection, and Reservoir Assessment. The scope of the Production and Injection work will include the following:

1) Inspection of existing wells, wellheads, primary separator, brine handling system and injection system

2) Repair and replacement of above facilities as necessary for the program 
3) Monitoring of production, handling, and injection systems during the testing portions of the program

4) Evaluation of the need for brine cleanup prior to injection

5) Evaluation of brine cleanup system designs and operating results (assuming need determined in 4 above).

The scope of the Reservoir Assessment part of the work will include the following:

1) Measurement of pressure, temperature, and flow rate from Sinclair No. 4 over time

2) Periodic measurement of elevations from the subsidence monitoring system located near the test site

3) Transmittal of brine temperature, pressure, and flow rate data to other government-funded investigators such as Systems Science and Software for their reservoir modeling efforts

4) Summarization of reservoir assessment studies conducted by previous investigators. These studies were acquired along with the Mono, SPL, PPC leases in the Salton Sea.

The major technical objective of the Reservoir Subprogram is to demonstrate the technical feasibility of producing, handling, and injecting geothermal brines from the Salton Sea KGRA. In addition, estimates will be made regarding the number and kinds of wells which should be drilled to serve a pilot power and mineral extraction plant.

\section{(4) Area Resources Test Facility}

The technical objective of this subprogram is to construct and operate a geothermal brine and steam facility where (1) advanced geothermal power generating equipment and concepts can be tested for various industrial, academic, and laboratory organizations that request such services; (2) nonelectric (i. e., process heating, desalination, etc.) applications for liquid dominated geothermal resources can be identified, studied, and evaluated; (3) advanced mineral extraction processes can be tested and evaluated; and (4) geothermal reservoir resources can be defined in terms of total extractable energy content, 
thermodynamic properties, estimated flow characteristics, and utilization potential. The testing of advanced concepts will include tests of special instrumentation for application to plant operation and monitoring and to reservoir assessment. The reservoir definition objective encompasses the testing and verification of various geothermal field measurements for geothermal applications.

In order to achieve the above stated objective, the scope of work under Phase 1 will consist of a systematic survey and compilation of requirements for test facilities as identified by various organizations involved in the field of geothermal energy. These requirements will then be evaluated and factored into a preliminary design and cost estimate of an Area Resource Test Facility. The preliminary design will be submitted to ERDA for review and evaluation. Assuming approval by ERDA for additional funding, a final design will be completed and be followed by the construction and operation of the facility in accordance with the stated objectives.

\section{b. Program Logic}

The technical scope of the program, as indicated in Section B.2.a, is divided into four major subprograms: Power Generation, Reservoir Production, Mineral Recovery and Area Resource Test Facility. To allow attainment of program objectives in an orderly manner and to assure a continuing assessment of results at appropriate times, the overall proposed program is divided into three phases, Phase 0,1, and 2 .

Phase 0, which is expected to be completed by mid-1975, is depicted in Figure 6, "Program Logic Diagram - Phase 0." The result of Phase 0 studies has been identification of the research and development activities required to construct a pilot plant. In addition, Phase 0 includes the ongoing installation of a semi-closed injection system (brine handling system) between wells to facilitate field research and development work.

Although the work comprising Phase 0 (funded by the Participants) is not within the scope of the program being proposed for ERDA support, a discussion of the information it has and will produce provides some background to this proposal and establishes the basis for the work proposed for Phase 1 . The tasks in Phase 0 consisted of the refurbishment of an existing production well 


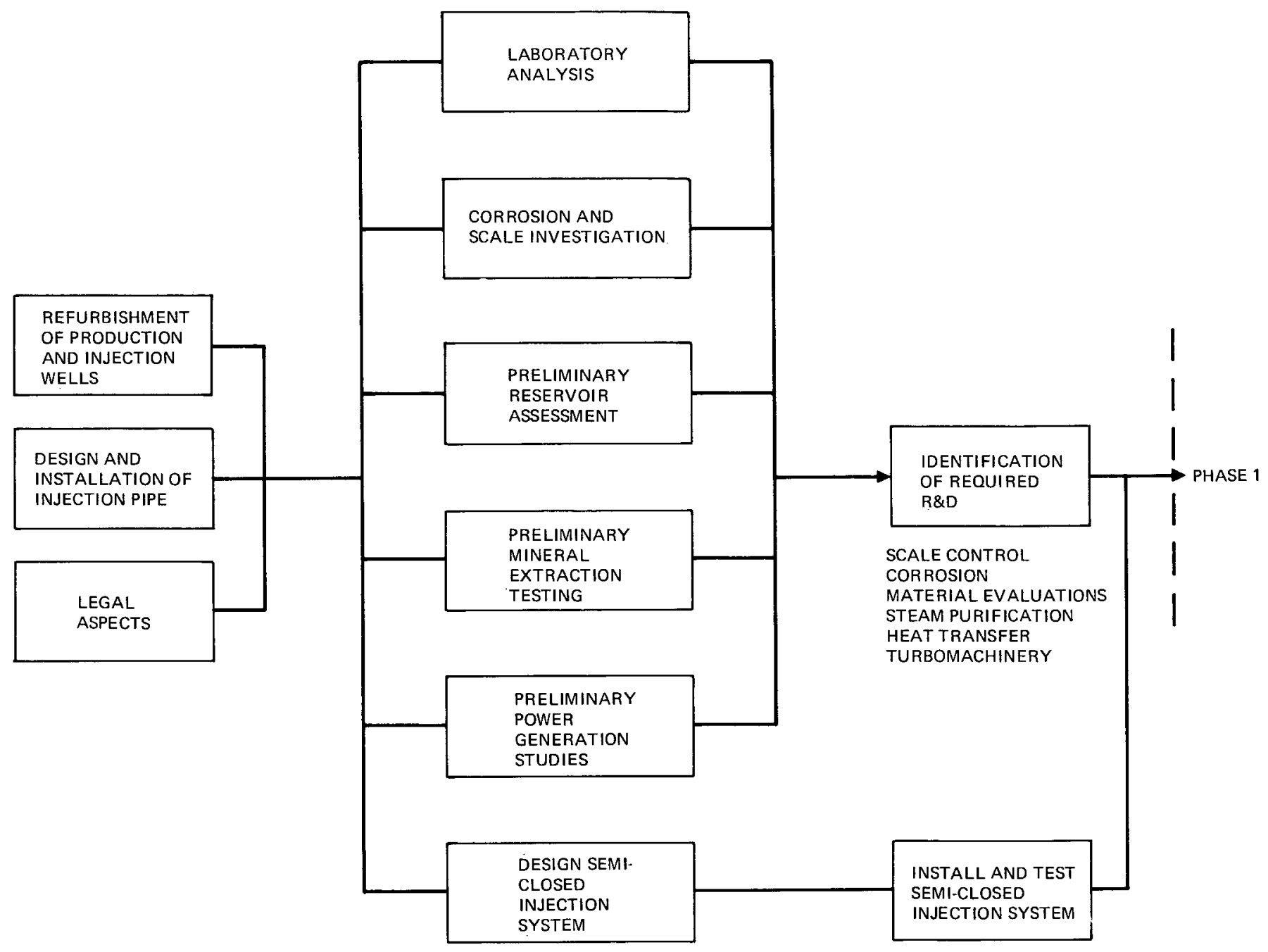

Figure 6. Program Logic Diagram - Phase 0 
and an existing injection well, and the design and installation of an injection pipeline. This work will permit the utilization of these wells for specific studies and tests required in Phase 1. At the same time, various laboratory tests, and corrosion and scaling control studies were conducted in order to identify $R \& D$ requirements relative to scaling control, corrosion, material selection, and steam purification. Preliminary design of a field power generation test module was also completed. Preliminary reservoir assessments were also made, and, coupled with preliminary power generation studies, resulted in the identification of a set of about ten reasonably promising power cycles. These ten concepts, which were then evaluated for suitability for commercial power generation, fell into three primary categories: direct cycle, binary cycle, and total flow. Thus, the Phase 0 work has provided some semi-quantitative evaluations relative to the commonly recognized problem areas in the development of geothermal power from high saline brines, namely, scale control, corrosion, material selection, steam purification, heat transfer, and turbomachinery. It has provided an identification of some of the major problems that must be solved in the economical utilization of Salton Sea KGRA brines for the production of electrical energy. One task which remains to be accomplished in Phase 0 is the construction, checkout, and operation of a semi-closed well injection system. This task is expected to be accomplished by mid-1975. Another task currently underway and expected to be completed within the next few months is a parametric study of scaling processes and a series of laboratory tests of promising scale control methods. The methods concern scale control at the operating surface (static, dynamic, and brine modification) and scale control upstream (precipitation, packed beds, etc.). Phase 0 has therefore identified the major R\&D requirements for the Salton Sea geothermal area and will provide fundamental data and a basic brine flow system that will allow Phase 1 tests to proceed smoothly and logically.

The total, privately funded, expenditures associated with Phase 0 activities will be approximately 2.2 million dollars. These costs include lease payments, salaries, and research and development expenditures. The costs are broken down by category in the Budget section of this proposal. 
Phase 1 activities involve testing of critical subsystems for power generation, mineral extraction, and reservoir production and injection facilities, and preparing a preliminary pilot facility design based on evaluation of the testing. An Area Resource Test Facility (ARTF) is included in Phase 1 to serve as a test facility for developmental geothermal utilization concepts on a continuing basis. Figure 7, "Program Logic Diagram - Phase 1," outlines the proposed approach to Phase 1 .

The Power Generation Subprogram has as its primary tasks, development of a requisite technology for electric power production, and completion of overall systems engineering for a geothermal-electric pilot plant. The major subtasks include: the selection, by means of tests and analyses, of a workable scale and corrosion control method, the selection of optimum materials of construction for the plant components, and the selection, again by tests and analyses, of an optimum energy conversion or power cycle concept. The output of all of these subtasks will be used in an analysis of the overall power generation concept from the standpoint of its economics, its environmental impact, and its technical feasibility: On the basis of this analysis, recommendations and specifications for and a preliminary design of a 10-MWe geothermal pilot power plant will be established. A concurrent study to assess the risks and desirability of substituting a 50-MWe demonstration plant for the pilot plant will be made.

The Minerals Recovery Subprogram includes the major tasks of selecting an optimum mineral recovery process, recommending a brine cleanup process for injection enhancement, engineering mineral recovery and brine cleanup facilities, constructing and operating the facilities, and analyzing the results from an environmental, technical, economic, and operational standpoint. The results of these efforts will be used to prepare a preliminary design of mineral recovery and brine cleanup facilities of sufficient scale to match the experimental power plant facility designed in the Power Generation Subprogram.

The Reservoir Production Subprogram includes the major subtasks of inspecting production, injection, and interwell systems equipment; repair and replacement of facilities as necessary; monitoring of the production, injection, and interwell systems operations; evaluation of brine cleanup for injection enhancement; measurement of brine characteristics and potential subsidence 


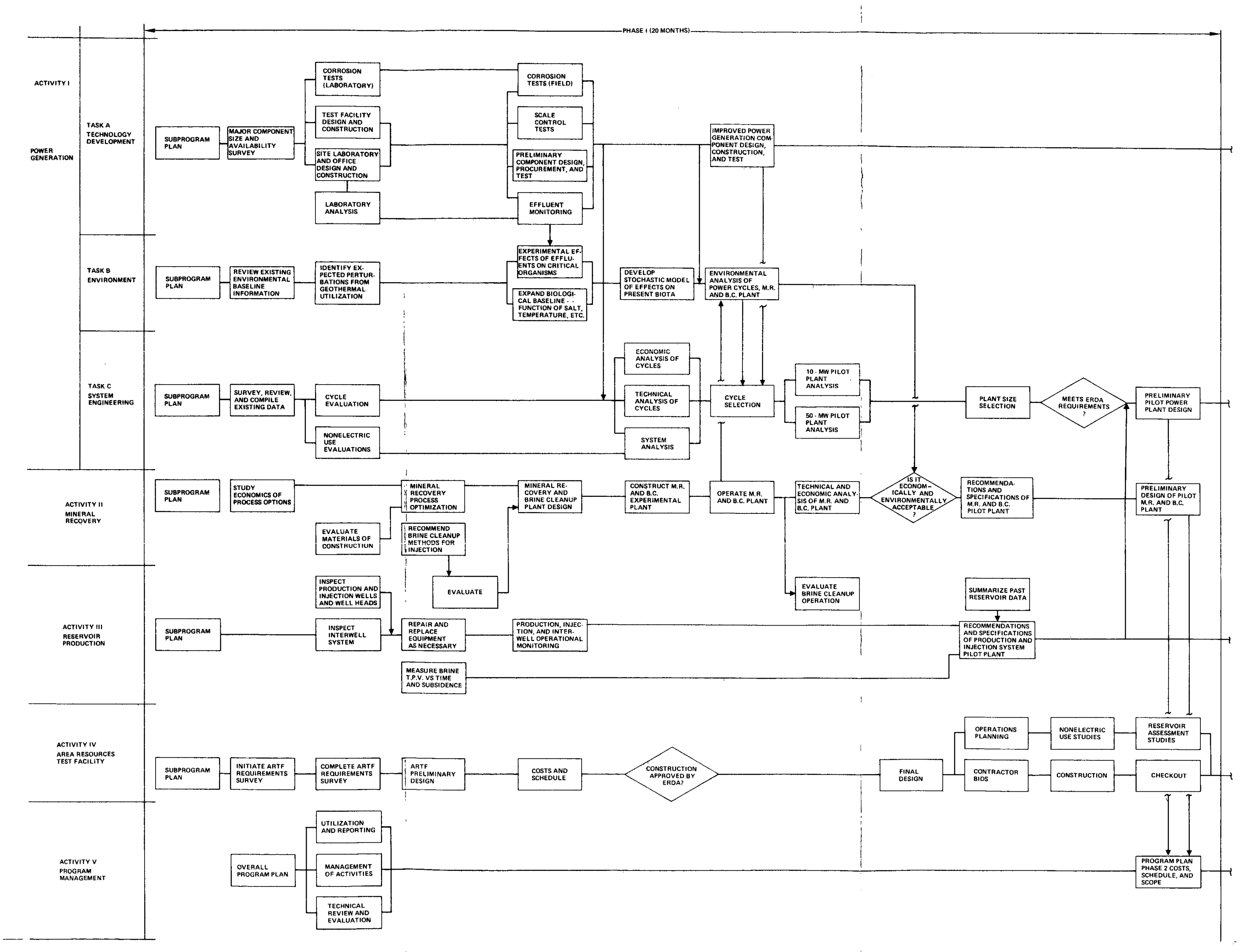

Figure 7. Program Logic Diagram - 
I 
vs time, and summarization of past reservoir assessment work. The results of these subtasks will be used to prepare recommendations and specifications for production and injection systems to be used in the preliminary design efforts of the pilot power and mineral recovery plants.

The major Phase 1 subtasks of the Area Resource Test Facility Subprogram are establishment of the requirements for the ARTF, preliminary design, evaluation, final design, construction, and operation of the ARTF.

The final product of Phase 1 will be a program plan for design, construction, and operation of a pilot geothermal utilization facility. Phase 1 will provide a sufficient amount of test data and an adequately thorough systems/analysis, on the basis of that data, to allow an assessment regarding program continuation.

Phase 2 covers, principally, a continuation of testing of critical geothermal power plant components, such as heat exchangers, separators and scrubbers, and the final design, construction, operation and evaluation of the experimental pilot utilization facility. The evaluation will be combined with detailed economic, environmental impact, reservoir and electric network studies to obtain a detailed set of specifications and recommendations for a demonstration geothermal utilization facility including a 5-MWe power plant. This phase is depicted in Figure 8, "Program Logic Diagram - Phase 2."

Many of the program subtasks have been investigated in varying degrees by many individual companies and laboratories over a long period of time. It is the intention of this program to recognize, evaluate, and incorporate into the work scope, where appropriate, the information that has been generated and is in progress under related programs.

In summary, therefore, the program logic is based upon the utilization of the basic facilities and the preliminary scaling and power cycles studies that have been and will be provided by the Phase 0 effort. These facilities will provide the initial test bed for conducting detailed field tests of scale and corrosion control, mineral recovery processes, reinjection and well flow characteristics, and gaseous effluent control, if any is required, and for preliminary component testing and preliminary pilot plant design of Phase 1. The results of these tests will provide the needed technological information for reliable final component design and test, and final design operation and analysis of the pilot plant. This 
I. POWER GenERATION PILOT PLANT

II. MINERAL EXTRACTION

$\infty$
IMPROVED COMPONENT
TESTING - CONTINUED

(IF NECESSARY

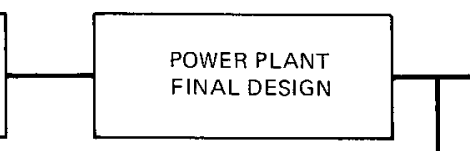

POWER PLANT

CONSTRUCTION

TEST, AND OPERATION

SPECIFICATIONS AND
RECOMMENDATIONS

RECOMMENDATIONS
LARGE SCALE

PANER PLANT

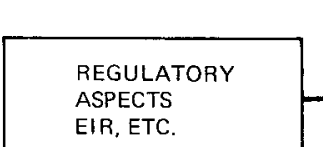

EIR, ETC.

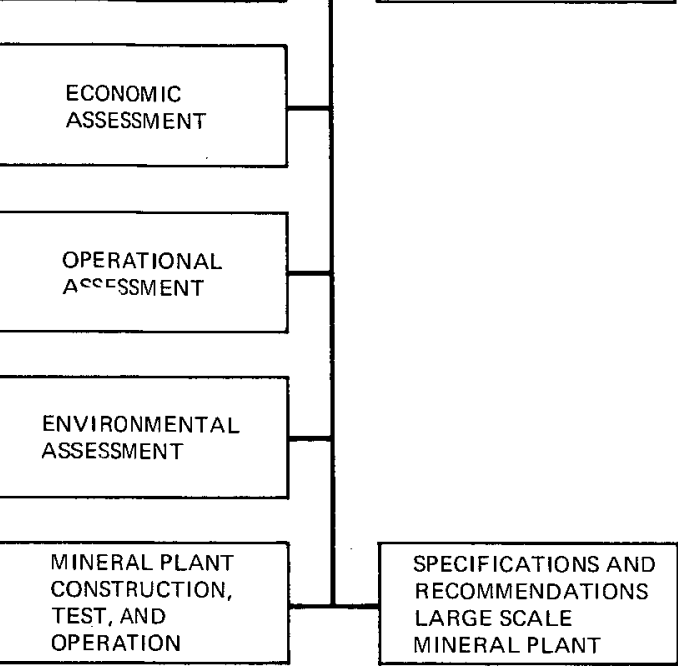

MINERAL PLANT FINAL DESIGN

OPERATION

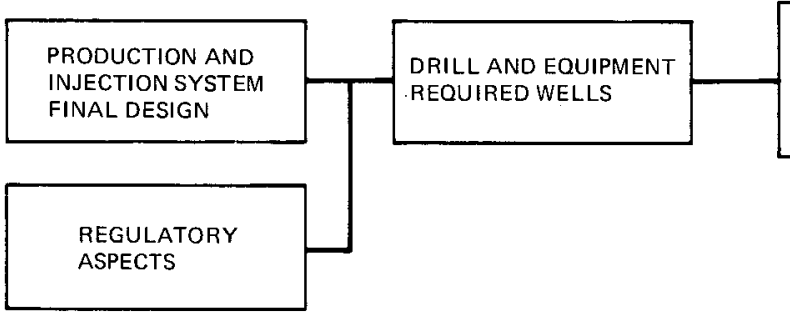

\section{PRODUCTION AND \\ INJECTION SYSTEM}

CONSTRUCTION

AND OPERATION

$\square$

SPECIFICATIONS AND

RECOMMENDATIONS

LARGE SCALE

PRODUCTION AND
INSPECTION FACILITIES

IV. PROGRAM

MANAGEMENT

\section{UTILIZATION, REPORTING, MANAGEMENT,}

TECHNICAL REVIEW, AND EVALUATION

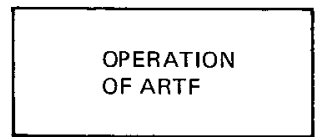

Figure 8. Program Logic Diagram-Phase 2 
systems engineering, programmatic approach will result in the most expeditious and cost effective route to a realistic assessment of the application of high salinity, high-temperature geothermal resources to power generation in the U.S. 
3. Work Statement

a. Phase 1

The objective of the 20-month Phase 1 effort is to advance the current technology for the generation of electric power from high temperature, high salinity geothermal brines. Phase 1 work will result in the following:

1) Completion of a preliminary design and cost estimate for a pilot geothermal brine utilization facility.

2) Economic and environmental evaluations of high temperature, high saline geothermal brine utilization for electric power generation and mineral recovery.

3) Construction of an Area Resource Test Facility (ARTF) where advanced geothermal utilization concepts can be tested and evaluated.

In order to meet the Phase lobjective, the following specific activities, tasks, and subtasks will be performed. The relationship of tasks and subtasks in different subprograms is shown in Figure 8.

Activity I - Power Generation Subprogram

Task A - Technology Development

The technology development effort is divided into six subtasks; the first deals with the fabrication and installation of a geothermal brine-flashed steam test facility; the second concerns the set-up of a temporary and portable laboratory and office facility at the site; the third involves the characterization, and experimental study of methods to control scaling; the fourth deals with the characterization, development, and testing of methods to control corrosion and erosion (this effort will include the studies of materials compatibility and selection); the fifth subtask concerns the development and testing of power cycle components; and the sixth subtask involves effluent monitoring.

Subtask 1 - Energy Extraction Test Rig

The design (accomplished under the Phase 0 effort) of a brine and steam energy extraction test rig for use in the field at Sinclair Well No. 4 will be modified to include a section for testing, under Subtask 5, three power components: a secondary flash evaporator, a heat exchanger, and a steam scrubber. 
In order to test a heat exchanger, a clean condensate supply loop that will circulate water or an organic fluid will also be designed and made part of this energy extraction test rig.

The test rig will be partially shop and partially field fabricated. The shop fabricated parts will be shipped to the site, installed, and connected to the field-erected portions. Instrumentation and controls will be connected to existing site power facilities. The components required for rejection of the brine and steam effluents from the test rig will be delivered as part of the site equipment. The rig will be checked out and an operating manual will be prepared. A commercial-type steam scrubber will be fabricated or purchased and delivered to the site. This energy extraction test rig will consist of three functional units: one for testing scale and corrosion control methods using well brine, one for investigating corrosion and materials problems using flashed steam and one for power component testing with brine or steam. Of the three power cycle components to be tested, only the steam scrubber which was included in the Phase 0 program will be provided under this subtask. The other two will be provided under Subtask 5.

After this test rig has been used to carry out scale control tests (Subtask 3), corrosion control tests (Subtask 4), and the preliminary component tests (Subtask 5a), additional design modifications will be carried out in order to accommodate the testing of three additional power cycle components: a turbine blade, a valve, and a pump impeller. The design modification will also include provisions for testing a second generation heat exchanger using an organic working fluid on one side and steam or brine on the other. These four power cycle components will be provided under the scope of work of Subtask 5b. The test rig modification will include the procurement, installation, and checkout of auxiliary, commercially-available, brine and/or steam handling pipe, pipe fittings, and other components, as necessary, to handle the additional testing capability requirements. The operating manual for the facility will be revised to incorporate data and procedures for the new capability section.

Subtask 2 - Site Laboratory and Office Facility

A commercially available trailer containing approximately $600 \mathrm{sq} f \mathrm{ft}$ of floor space will be purchased or rented. A detailed set of space allocation and functional requirements will be formulated and an engineering drawing specifying 
the interior layout will be prepared. The interior will then be partitioned to provide office space, a small laboratory, and rest room facilities. The necessary structure and facilities will be installed and the trailer will be delivered to the site and set up.

The following equipment will be procured for the laboratory: a gas chromatograph, an analytical balance, a furnace and furnace controller, a laboratory oven, a fume hood, two $\mathrm{pH}$ meters, a microscope, and an automatic titrator in addition to such laboratory items as chemicals and reagents, laboratory glass ware, and hardware. Desks, tables, chairs, two filing cabinets, and air conditioners will be obtained for the office and laboratory. The rest room facility will be completely equipped and will include a shower facility. The laboratory will be used to provide analytical support capability for the ongoing technology development and environmental studies until the ARTF becomes available.

\section{Subtask 3 - Scale Control Tests}

The initial test program on scale control will serve to verify under realistic brine conditions the results obtained in the laboratory tests that are being completed under the Phase 0 effort. The following scale control concepts will be tested using the brine section of the test rig.

1) Static surface modifications involving the prevention of scaling by the use of very smooth surface finished, "non-stick" coatings, or oilwetting; also, the use of sacrificial surfaces that will readily scale and thereby protect critical surfaces.

2) Dynamic surface modifications involving the application of heat, ultrasonic vibrations, an applied low (dc) voltage, and gas evolution through the application of a high dc voltage.

3) Brine modifications using scale control, chemical additives or adjustment of $\mathrm{pH}$. These tests involve early precipitation of scale formers (seeding) or promotion of controlled scaling.

As part of this scope of work, various test specimens and holding fixtures will be fabricated.

After these tests are performed and evaluated, a second and final series of scaling control experiments under this Phase 1 program will be conducted to 
provide more specific data pertaining to the selection of a power cycle under Subtask C-1. This series of tests will, at a minimum, consist of studies of the most promising control methods on critical portions of such power generating components as the first and second stage separators, the mixing venturis and scrubbers, a heat exchanger, and the turbine.

Subtask 4a - Laboratory Corrosion Tests

Laboratory tests will be carried out to characterize the corrosion and materials compatibility problems associated with a pilot plant design and to guide the conduct of field tests. For the laboratory experiments, static and rocking pressure vessels (autoclaves) will be used. Temperatures in the range from 350 to $450^{\circ} \mathrm{F}$ will be employed. The test specimens will be exposed to a variety of environments, selected from the following:

1) Full-flow Sinclair No. 4 brine, with and without noncondensible gases

2) Brine from the Sinclair No. 4 primary separator

3) Steam from the Sinclair No. 4 primary separator, and with and without noncondensible gases

4) Redistilled steam from the Sinclair No. 4 primary separator, with and without noncondensible gases.

Specimens will be exposed to Items 3 and 4 in the vapor phase. These above media were selected as providing the best test for alloys to be used in the power generation equipment.

Test specimens will include U-bend (stressed), welded, and coated metals and alloys. The selection of metals for testing will depend on anticipated per formance, published data, and anticipated large-use cost.

Potential coatings to be used on structural materials will be selected from among such materials as Riton, Teflon, and Sermetal. Both fully and partly coated specimens will be tested. In some cases, specimens will be partly covered to investigate crevice corrosion.

Subtask $4 \mathrm{~b}-$ Field Corrosion Tests

The test facility that is fabricated and installed at the site under Subtask 1 will be used to perform corrosion, erosion, and material compatibility tests in 
the field. Standardized corrosion coupon test spool assemblies (approximately $8 \mathrm{in.}$ in diameter by 16 in. long) will be designed and fabricated for easy removal and reinstallation without affecting operation of the test facility. They will have test specimens of materials currently considered most promising (mild steel, low alloy steels, and Type 400 and 300 stainless steels) as well as marine alloys. These specimens will then be exposed to the flow of brine and steam for periods of from 2 to 4 weeks each. Additional materials may be studied as warranted in the process of selecting materials that have an acceptable lifetime under the most severe brine and steam conditions. The field corrosion tests will also involve tests on potential coatings to be used on structural materials. Both fully and partly coated specimens will be investigated.

\section{Subtask 5a-Preliminary Component Tests}

The power component section of the test facility will be used initially to conduct tests on three power cycle components: a second-stage flash evaporator, a small-scale heat exchanger, and a steam scrubber. The steam scrubber as previously mentioned will be provided under Subtask 1. On this subtask, the design and specification for the second stage flash evaporator and the heat exchanger will be prepared. Each unit will be fabricated at AI or will be purchased, depending upon the most cost effective approach. These units and the steam scrubber will then be installed at the test facility, checked out, and operated. The tests on these articles, which will basically be commercial-type units, will primarily involve performance and reliability evaluations. The scale and corrosion problems associated with these items will be investigated in conjunction with Subtasks 3 and 4 above.

Subtask 5b-Final Component Tests

In conjunction with the cycle selection study (Subtask C-l below) and the results of preliminary component tests, a second and final series of component tests will be performed in order to obtain data directly applicable to large-scale components. These tests will require modifications to the test facility (covered under Subtask 1).

The following commercial-type components will be provided under this Subtask for purposes of testing: a turbine blade, a typical valve, a pump impeller, and, if warranted on the basis of the preliminary test results, a heat exchanger 
for use with an organic working fluid. These units will be installed in the test section and tested for performance and reliability.

The results of these component tests will be used, in conjunction with the results of the scaling, corrosion, erosion, and materials selection tests, to arrive at a design basis power cycle under Subtask C-l and to complete a preliminary design of a pilot power plant under Subtask C-4. These tests will also provide preliminary data leading to a set of requirements and specifications for testing, in Phase 2, of full-scale components to be used in the pilot plant.

Subtask 6 - Effluent Monitoring

Gas and liquid (brine) sampling equipment will be procured, or designed and fabricated. With this equipment, samples of steam, other gases, brine, and solids will be taken as required to monitor well production variations, component and test operation releases, and other general effluents. At the site, the gas samples will be analyzed using gas chromatography and the liquid samples will be given routine analyses for total dissolved salts, $\mathrm{pH}$, and iron and chloride concentrations. Also at the site laboratory, the solids will be analyzed for carbonate, $\mathrm{SiO}_{2}$, and total iron concentrations and for percent volatiles. Selected liquid and solid samples will be sent to AI's headquarters facility for more complete analyses that will include determination of cations by atomic absorption spectra techniques and of crystal species by $x$-ray diffraction methods. Results of these effluent measurements will be evaluated for environmental considerations under Task B, Subtask 2 (Identification of Hazardous Components of Geothermal Fluids). Brine and steam characterization analyses will also be performed in support of the scale and corrosion control tests and the component tests being conducted within the Technology Development Task.

\section{Task B - Environment}

Subtask 1 - Expansion of Biological Baseline

As stated in Section I-B-1-g, very little usable quantitative information is available on the managed or natural ecosystems in the vicinity of the Salton Sea KGRA, therefore, the major thrust at initiation of this program will be the careful quantitative inventory of the environment and biota. These data will be taken to maximize their effectiveness in developing models of relationships between biota and those environmental parameters that could be altered by geothermal development. 
All sampling will be based on quadrants selected from a uniform grid system covering the area. Sampling will be stratified following the methods of Cochran ${ }^{(11)}$ to maximize cost effectiveness. The size and number of quadrants will be determined from species vs area, species vs sample-size curves, and accurnulative species diversity curves to insure that the samples yield sufficient information to proceed with ecological analysis. The data will be collected in the form of site (quadrant) by biotic attribute (species) and site by abiotic attribute (environmental parameters) matrices. Several methods of analyzing the functional relationships between the environmental parameters and the biotic attributes from such data have been developed. Because of the heterogeneity of the environment under investigation, a combination of these methods will be used. Basically, a classification analysis will identify site groups from the biotic attributes and the environmental parameter responsible for the existence of these groups determined by multi-variate discriminate analysis. The dis criminate scores will identify the dominating environmental influences. Using existing sites or by sampling additional sites to maximize spread across these environmental gradients, the data will be re-analyzed by ordination of biotic attribution, and the principal axes regressed on the known environmental gradients. Stochastic models that will predict the probable biotic association can then be formulated for any change in these environmental gradients.

The biotic attributes will be measures of the abundance of the species of both plants and animals. For plants these measures will include relative frequency, relative density, relative percent cover, and importance value.

Animal data will consist of population estimates of each species at each site. Standard censusing methods for both vertebrate and invertebrate animals will be used. This inventory phase will be continued over one full annual cycle.

The environmental parameters measured will be those most directly related to effluents from geothermal conversion processes and will vary in importance from process to process. However, they are basically concerned with concentration of mineral salts in soil or water and temperature. Gaseous effluents might also occur, but since gradients in these contaminants are difficult to measure and/or control in open field conditions, their influence will have to be assessed solely by laboratory experiment. 
Subtask 2 - Identification of Hazardous Components of Geothermal Fluids

Although chemical analysis of the fluids will be an integral part of the Mineral Recovery Subprogram, the emphasis will be on major extractable constituents. There are other components that could be environmentally hazardous. First, noncondensible gases might be unavoidably liberated into the atmosphere so it will be important to establish the concentration of such gases. Secondly, the brines may contain trace elements that may be liberated from process equipment or diffuse into the environment from storage. Only minute amounts of some elements are potentially hazardous, so a complete microconstituent analysis will be made to characterize the brines chemically with respect to trace elements.

Subtask 3 - Experimental Effects of Effluents on Organisms

Where gradients in specific salt or trace element concentrations away from previous brine storage areas are not available, critical organisms chosen from Subtask 1 will be tested under laboratory conditions for responses to realistic levels of contamination of salts, trace elements, or noncondensible gases. All experiments will be conducted in controlled environment chambers. A series of chambers will be constructed so that the selected organisms can be exposed to various levels of contamination from background to maximum expected under worst conditions. The response of these organisms will be used as keys to the response of the biological system. The functional relationship between contaminants and biotic response developed from these experiments will also be incorporated into the environmental impact assessment models.

Subtask 4-Development of Assessment Models and Evaluation

The models developed from ecological analysis and experiments will relate the response of the biota (or critical components of it) to changes in environmental gradients expected from the release or diffusion of hazardous components of geothermal fluids into the environment. Positive or negative scores will be available for each environmental parameter for each biotic unit in the present biotic data matrix which will allow, by multiplication, the creation of the predicted biotic data matrix. This will represent the most likely assemblage of plant and animal species expected under the projected environmental pertubation.

A comparison of all alternative power generation processes and attendant mineral extraction schemes will be made on the basis of minimal environmental 
impact. Any process that would have an unacceptable ecological impact will be eliminated from further consideration at this stage.

Task C - Systems Engineering

Subtask 1 - Technical Analysis of Candidate Cycles

The results of the preliminary cycle screening studies that were performed in Phase 0 will be used to initiate a detailed evaluation of the various candidate power cycles from the standpoint of technical feasibility. These studies will draw heavily upon the data generated in Subtasks 3, 4a, 4b, 5a, and 5b of Task A, on particular scaling, corrosion, erosion, and materials problems, and the performance and reliability potential of the various components required for each type of cycle. The major components comprising each candidate power cycle will be identified, sized, and evaluated individually as well as from an integrated standpoint in order to assess, on the basis of the test data and literature information, the feasibility of the system as a whole, including such factors as well flow and reinjection. The work being performed by other laboratories and organizations will be reviewed in detail in this subtask and discussions will be held with appropriate personnel in order to take into account the body of information that has already been developed in this area. In particular, the feasibility of the organic binary cycles and the total-flow concepts will be carefully reviewed to establish the current state of the art. This subtask will provide a ranking of the candidate power cycles in accordance with their technical feasibility and will culminate in the selection of a pilot plant power cycle on the basis of this ranking, as well as on economic considerations (as assessed under Subtask 2 of Task C) and environmental impacts (as assessed under Task B).

Subtask 2 - Power Cycle Economic Analysis

Several candidate systems may show an acceptability from the standpoint of technical feasibility, particularly if the scaling can be adequately controlled. Final cycle selection will be dependent upon economics and environmental considerations. An economic evaluation of the technically feasible concepts will be performed, taking into account the potential for mineral extraction as evaluated under Activity II of the overall program, if it differs significantly from one cycle to the next. Comparative bus bar costs will be estimated on the basis of plant capital costs and the efficiency of the power cycle. These cost studies will 
be performed in part by using the techniques developed at Battelle Northwest Laboratories for assessment of geothermal power cycles. This subtask will provide a ranking of various technically feasible power cycles in terms of cverall projected costs and will take into account the results (as provided under Activity III) of the reservoir assessment in terms of the number of wells required and the need for total or partial reinjection.

Subtask 3 - Systems Analysis

An overall systems analysis of the electric power generation plant will be pe rformed for the preliminary cycle selection and for the final cycle selection (which may not differ from the preliminary cycle). The risks associated with omitting the pilot plant and going directly to a 50-MW e demonstration plant will be studied under this subtask. The expected pilot plant (first plant) system performance will be prepared for various operational conditions including startup, shutdown, normal, and off-design. Necessary control methods will be identified, and instrumentation requirements will be established. The overall plant requirements will be established for use in the preliminary design effort.

Subtask 4 - Pilot Plant Preliminary Design

Subtask 4 consists of a preliminary design of the 10-MWe pilot plant (or the 50-MW e demonstration plant). A system design description report will be issued on this design. The design will be based upon the results of the scaling, corrosion, and erosion control method tests and on the component tests, to the extent that these test results are available during the preliminary design effort. Equipment arrangement drawings, preliminary piping arrangement drawings, a process and instrumentation diagram, a single-line electric diagram, a control and instrumentation list, drawings of nonstandard components, and requirements for auxiliary systems will be prepared. In addition, a facility and building preliminary floor plan and sections and elevations, together with design requirements for bid, will be prepared. The arrangement drawings will include the turbine-generator and substation. In order to meet the schedule for the final design and construction of the pilot plant under Phase 2, specifications will be prepared for specific long lead time components, such as the turbine-generator. Contacts will be made with various vendors to discuss costs and schedules for modifiying, if necessary, existing brine and steam handling components and 
equipment. After vendor surveys are completed and a critical components list is compiled, requests for quotation on these critical items will be prepared. Vendors will be given the opportunity to prepare quotations and schedule estimates. Purchase orders will be prepared as necessary to meet the overall pilot plant construction schedule. Periodic design review meetings will be held with cognizant personnel of ERDA.

Activity II - Mineral Recovery Subprogram

Task A - Selection of Mineral Recovery Process

Subtask 1 - Determine the optimum materials of construction for minerals recovery equipment to minimize scale formation, corrosion, and erosion.

Subtask 2 - Estimate the capital and operating costs and projected income from alternate process options.

Subtask 3 - Select the optimum mineral recovery process based on economics and expected lifetime.

Task B - Recommendation of Brine Cleanup Methods

Subtask 1 - Define the needs of a brine cleanup facility for facilitation of injection into Sinclair No.3. Coordination with the Reservoir Production Subprogram will be required.

Subtask 2 - Study alternate processes for brine cleanup to facilitate injection including neutralization and seeding methods, and recommend most promising methods to Reservoir Production Subprogram Manager.

Task C - Design and Engineering of Facilities

The design and engineering of both mineral recovery and brine cleanup facilities can proceed in parallel assuming the need for brine cleanup to enhance injection is determined. If it is found that injection can take place without special brine cleanup, the brine cleanup portions of the work would be deleted. The subtasks involved in this task are outlined below:

Subtask 1 - Size and select process equipment,

Subtask 2 - Prepare equipment layouts and piping designs, 
Subtask 3 - Determine utilities requirements,

Subtask 4 - Determine pollution control equipment needs and select equipment.

Task D - Construction of Facilities

Subtask l - Staff field crews.

Subtask 2 - Purchase, control, and expedite materials.

Subtask 3 - Complete foundation design and installation.

Subtask 4 - Install equipment and process piping.

Subtask 5 - Insta.ll electrical, instrumentation, and utility subsystem equipment.

Subtask 6 - Check out facilities.

Task E - Operation of Mineral Recovery and Brine Cleanup Facilities

Subtask 1 - Determine optimum operating points for effective brine cleanup at minimum cost.

Subtask 2 - Evaluate operating variables on minerals recovery, yield, operating cost, etc.

Subtask 3 - Provide analytical backup services for brine cleanup evaluation and minerals recovery plants.

Task F-Analysis of Facilities

Subtask 1 - Prepare an analysis of the environmental effects of the mineral recovery and brine cleanup facilities (by Power Generation personnel).

Subtask 2 -Prepare technical and economic analyses of the facilities.

Subtask 3 - Prepare an operational analysis of the brine cleanup facilities (by Reservoir Production personnel).

Task G-Pilot Plant Preliminary Design

This task will include a preliminary design of a mineral extraction and brine cleanup (if necessary) facility of sufficient scale to match the pilot power generation plant discussed in Task C, Subtask 4, of the Power Generation subprogram. 
A complete set of drawings covering the plant, including buildings and process equipment will be prepared.

Activity III - Reservoir Production Subprogram

Task $A-$ Brine Production and Injection

During the proposed program the production, injection, and interwell brine handling systems which were installed in Phase 0 with Participants' funding will be operated under this task.

Subtask 1 - Equipment Inspection

A pre-flow inspection will be made to assure that the production and injection wells, piping and valving, and the interwell brine handling facilities are capable of safe operation throughout the program test period. The well head will be disassembled, well casing condition determined by down-hole inspection tools, and interwell system condition determined by visual and ultrasonic inspection as necessary.

Subtask 2 - Repair and Replacement

All production, injection and interwell system facilities will be returned to rated condition prior to initiation of testing.

Subtask 3 - Operational Monitoring

The production, injection, and interwell systems will be operated and maintained as required by the Participants. The entire well flow and fluid transport system has been designed to the maximum extent possible with redundant features or bypass capacity to eliminate shutdown for scale removal and cleaning. Periodic disassembly and cleaning appears to be the only alternative to reduced fluid throughput. During the Phase 1 test flow periods, a high labor effort will be required to perform this work. The critical points of instrumentation contacts, pumps, and control valves will receive scheduled scale removal maintenance. The separator and flash tank which are points of pressure reduction and, therefore, subject to large scale deposition will be serviced as necessary.

The operation of production andinjection systems will be the responsibility of the Participants, who will invoice the Principal Investigator for their operating expenses. Reservoir Production Subprogram personnel will monitor system 
operation. Should other researchers (e.g., Lawrence Livermore Laboratory) require use of the production and injection systems concurrent with the needs of this proposed program, operating costs will be prorated between users.

The amount of the Participants' invoice to the Principal Investigator will be determined based on the operating and maintenance expenses associated with the production, handling, and injection systems. Should major maintenance be required, (e.g., reconditioning of Sinclair No. 4 to maintain adequate brine deliverability), the cost of the work will be reflected in the Participants' invoice to the Principal Investigator based on a predetermined contractual formula.

\section{Subtask 4-Brine Cleanup Facilities}

In cooperation with the Minerals Recovery Subprogram Project Manager, Reservoir Subprogram personnel will determine the need for a brine cleanup system to facilitate injection (see Mineral Recovery Subprogram Task B).

Should a brine cleanup facility be required, the specification of facility requirements and evaluation of designs and operating results will be performed in this subtask.

Task B - Reservoir Assessment

Data on brine characteristics vs time and potential subsidence effects from well production will be collected, and past reservoir assessment efforts by other investigators will be summarized.

\section{Subtask 1-Brine Characteristics}

The temperature, pressure, and flow rate of geothermal brine produced and injected will be monitored and recorded throughout the proposed program. The information will be transmitted to an ERDA contractor, Systems Science and Software, for use in their three-dimensional reservoir modeling efforts. Subtask 2 - Subsidence Measurement

A subsidence monitoring system has been installed near Sinclair Wells 3 and 4 by the Participants. Periodic measurement of the elevations, and a determination of any subsidence vs time will be recorded. 
Subtask 3-Production and Injection System Recommendations

Based on the data obtained in Subtasks 1 and 2 above, and monitoring efforts of Task A, recommendations and specifications will be made for the production and injection system design that will serve the pilot power plant and mineral recovery system to be built in Phase 2 .

Subtask 4 - Summary of Past Reservoir Assessment Work

A contract will be executed with a university to perform a summarization study of past reservoir assessment work conducted by investigators such as Helgeson, Shell Oil Company, and Morton Salt Company. This study will be made available to investigators seeking information on the Salton Sea KGRA reservoir. Availability of this study will avoid duplication of past work. Activity IV - Area Resource Test Facility

The Area Resource Test Facility (ARTF) activities will be comprised of a phased sequence of tasks that consist of the following:

Task A - Requirements Survey

A survey will be performed in order to identify the experimental facilities and services required for the ARTF by potential university, laboratory, and industrial users. The results of a study by California Institute of Technology under NSF grant AER75-01748 will also be utilized in defining requirements for the ARTF. The Cal Tech study will include a definition of research which needs to be done in the Salton Sea KGRA. Suggestions for research efforts in the areas of geology, reservoir mechanics, brine chemistry, reservoir assessment, environmental geochemistry, nonelectric uses, and mineral recovery to be conducted at the ARTF by universities under the sponsorship of NSF, ERDA, and other agencies of the government will be actively pursued.

The ARTF will emphasize long-range research involving the total utilization of Salton Sea KGRA brines. This research will include power generation, nonelectric uses, mineral extraction, and reservoir definition work. Task B - Preliminary Design and Cost Estimate

A preliminary design that meets the principal needs as defined in Task A will be prepared. The design will be sufficiently complete to establish 
(1) approximate equipment sizes, types, locations, and quantities; (2) space requirements; and (3) physical plant size. The following drawings will be prepared:

1) Plant Arrangement (one drawing) - Includes locations and sizes for buildings, test pads, service roads, power substation, and boundary fencing.

2) Building Layouts (two drawings) - Encompasses control and instrumentation rooms, offices, facilities, heating and ventilating system, maintenance, and service areas.

3) Piping and Equipment on Test Pads (three drawings) - Includes plans and elevations for pipe runs from well or wells to pads and valve stations, and equipment locations on pads.

4) Electrical Distribution - Encompasses plant and test operations.

On the basis of this design, a preliminary cost and construction schedule will be prepared in report form and submitted to ERDA for review and evaluation. Assuming approval and funding by ERDA, Tasks C, D, and E will be carried out.

Task C - Facility Design

A final design of the ARTF will be completed. Bid packages will be prepared and submitted for bids by various contractors for facility construction. Task D-Construction

The ARTF will be constructed and checkout operations will be performed. Task E-Operation

The ARTF will be maintained and operated for the purpose of testing geothermal components, instrumentation, and concepts for requesting organizations. Activity V - Program Management

Certain specific tasks must be performed to assist the Principal Investigator in management of the proposed program. These tasks are explained below. A detailed discussion of program management philosophy and techniques is contained in Section I-C of the proposal. 
Task A - Detailed Program Plan - Phase 1

In order to effectively manage the Phase 1 Program, a detailed program plan will be developed as the first task of the program. This plan will include detailed work breakdowns, project procedures, schedule and cost information, and establishment of contractual arrangements with subprogram contractors in order to allow the Principal Investigator to properly control the program in order to meet its objectives.

Task B - Decision Criteria for Commercialization

To assist the Principal Investigator in making important program decisions, a set of decision criteria will be developed which will allow consistent evaluation of the potential commercial viability of geothermal-electric power production in the Salton Sea KGRA, vis-a-vis, alternate methods of electric power production. The decision criteria will be integrated into an analytical model by which the anticipated impacts of converting energy in Salton Sea KGRA brines to electricity can be evaluated against those of other base loaded power production techniques such as coal- and nuclear-fueled, steam-electric power plants.

The criteria will fall into the categories of Institutional Impacts, Legal Impacts, Environmental Impacts, and Economic Impacts (utilities and U. S.). If an approach being taken to produce power from Salton Sea KGRA brines has impacts in excess of those deemed desirable for a commercially viable generating system, the Principal Investigator will be able to adjust the program direction in order to remain within the envelope to be defined in the model.

As an example, one economic criterion for commercialization may be that the net cost of power production and delivery from the Salton Sea KGRA must be less than $\mathrm{H}$ mills/kWhr. The estimated costs of production and delivery from the power cycle being investigated minus the estimated credit in brine cost associated with mineral recovery must remain below $\mathrm{H}$ mills $/ \mathrm{kWhr}$ in order to justify continuation with the power cycle and mineral recovery scheme being investigated.

Task C - Site Preparation

The sites of Sinclair Wells 4 and 3 will be leveled, fenced and lighted, and existing calcium chloride process equipment at the Sinclair 4 site will be painted in 
order to beautify the test site area. The accomplishment of this task will result in a professional appearing site upon which to place the test facilities proposed for Phase 1 activities.

Task D - Program Plan - Phases 2 and 3

A detailed program plan for the Phase 2 effort will be prepared and a preliminary plan for a Phase 3 demonstration plant will be outlined. The Phase 2 plan will include logic diagrams, work breakdowns, costs, and schedules for (1) full-scale testing of the critical pilot plant components (if necessary), (2) performing a final plant design, (3) preparing component specifications, (4) ordering or fabricating components, and (5) managing the construction of the plant. The plan will also include costs and schedules for operating the plant, evaluating its performance, and preparing a final report.

b. Phase 2

The objectives of the Phase 2 Program efforts are the following:

- To design, construct, and operate a 10-MW e pilot scale geothermal brine utilization facility.

- To complete a preliminary design and cost estimate for a demonstration or commercial (50-MW e equivalent) geothermal brine utilization facility.

One of the major tasks of Phase 1 will be to develop a program plan for Phase 2. This program plan will include a logic diagram, work statement, schedule, and cost estimate for design, construction, operation, and evaluation of a pilot geothermal brine utilization facility. 


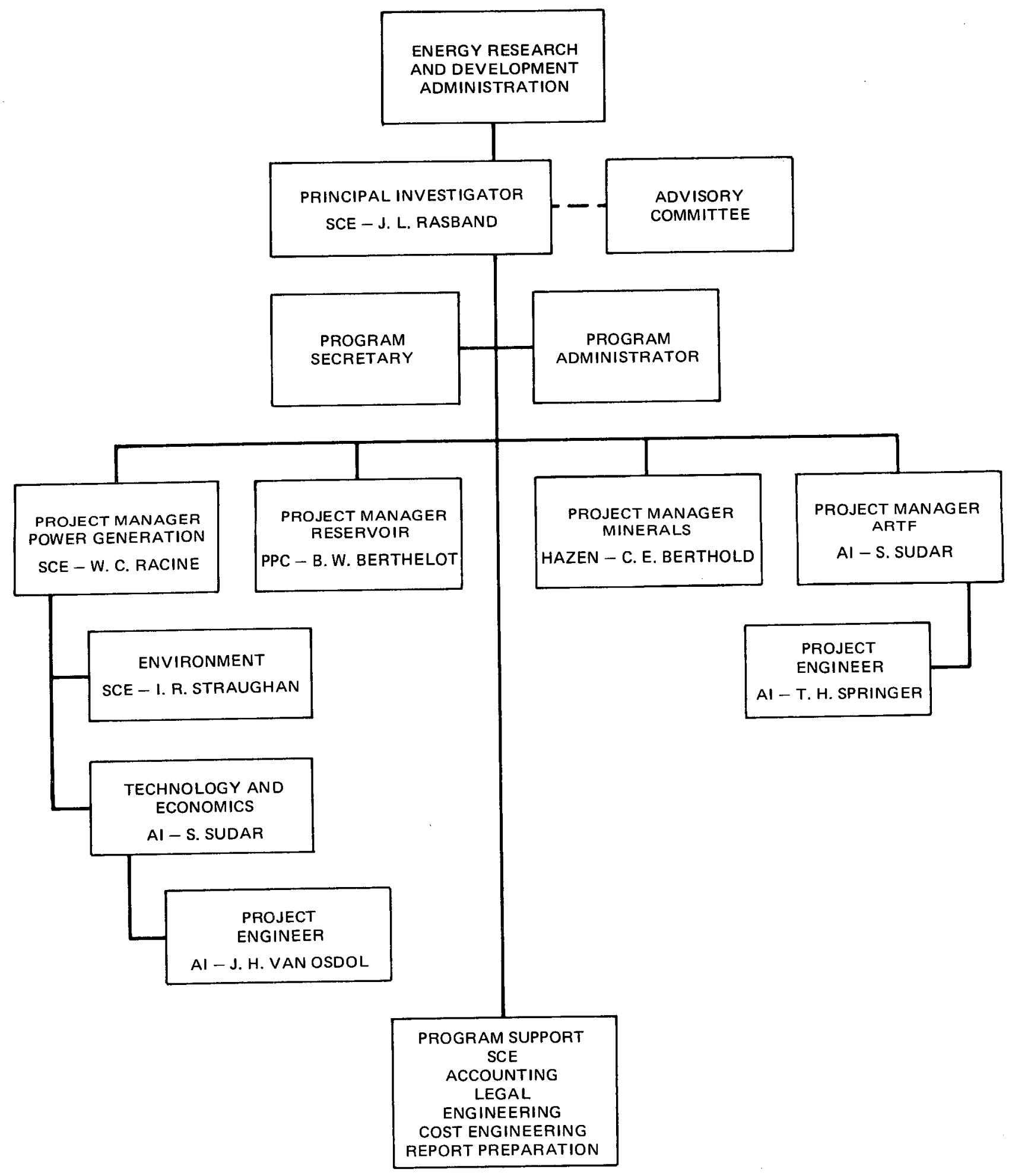

Figure 9. Project Team 


\section{PROGRAM ORGANIZATION AND MANAGEMENT}

\section{Management Approach}

This program will be directed and coordinated by the Southern California Edison Principal Investigator to allow a maximum amount of cross communication among people performing related tasks, while assuring the timely and efficient attainment of project milestones. Lines of communication between Subprogram Project Managers will be opened and closely monitored by the Principal Investigator to as sure proper coordination of work efforts.

Overall project control and coordination will be aided by holding monthly project review meetings, requiring weekly, intraproject progress reporting, and transmitting information and ideas between project team members on informal working papers.

Mr. J. B. Moore is the corporate officer within SCE who has overall responsibility for research and development programs. As Vice President, Mr. Moore is the official corporate representative for this program. Mr. Moore has assigned the responsibility of Principal Investigator for the program to Mr. J. L. Rasband.

\section{Organization and Management Controls}

\section{a. Program Team}

In order to implement the Phase 1 Program, a program team consisting of organizations and people expert in various portions of the work has been established. Team members include representatives of SCE, Atomics International, Hazen, and PPC, all under the direction of the Principal Investigator. The team selected to perform the proposed program is shown in Figure 9 .

The Principal Investigator, Mr. Rasband, will be responsible for meeting all program objectives involving cost, schedule, and performance. His authority will not be limited to direction of the program team, but will extend to SCE support organizations by virtue of his management position within the Company. When necessary, Mr. Rasband will interface directly with management personnel in the required service organizations. In addition, Mr. Rasband will have direct control over the activities performed in the subprograms: the 
NAME

*MR. D. PIERSON OR R. MITCHELL

*MR. R. CARTER

${ }^{*}$ MR. D. ANDERSON

*MR. G. STACEY

*MR. R.C. DABOVICH

*MR. BEN HOLT

*MR. T. HINRICHS

*DR. L.T. PAPAY

MR. C.M. LAFFOON

*DR. C.W. BERGE

*MR. W.C. MC CULLOCH

*DR. IAN KAPL.AN

*DR. P. PRATT

${ }^{*}$ MR. F. FULTON
ORGANIZATION

COUNTY OF IMPERIAL IMPERIAL IRRIGATION DISTRICT STATE OF CALIFORNIA STATE OF CALIFORNIA MORTON NORWICH, INC. THE BEN HOLT COMPANY MAGMA POWER COMPANY SOUTHERN CALIFORNIA EDISON CO. SAN DIEGO GAS \& ELECTRIC CO. PHILLIPS PETROLEUM COMPANY SOUTHERN PACIFIC LAND CO. UNIVERSITY OF CALIFORNIA AT LOS ANGELES

UNIVERSITY OF CALIFORNIA AT RIVERSIDE

LAWRENCE LIVERMORE LABORATORY

*HAVE AGREED TO SERVE ON COMMITTEE AS OF DATE OF PROPOSAL.

Figure 10. Advisory Committee 
Power Generation Subprogram because Mr. Racine reports to him functionally; and Reservoir Production, Mineral Extraction, and Resource Test Facility Subprograms by virtue of contracts which will be let to the Project Managers' organizations. The three major subcontractors, PPC, Atomics International, and Hazen, will be controlled by Mr. Rasband through principles established in written contracts to be executed with SCE.

$\mathrm{Mr}$. Rasband is experienced in both project and personnel management. He was Project Manager from conception of the $50 \mathrm{-MW}, \$ 8$ million, Substa tion Gas Turbine Project. Prior to this as signment he was a project engineer for the Ormond Beach Generating Station, a $1500-\mathrm{MW}$ project with a cost in excess of $\$ 200$ million.

The resumes of Mr. Rasband, the Principal Investigator, along with the Project Managers and other important team members are contained in Appendix D.

The Principal Investigator, Mr. Rasband, will devoce approximately 50\% of his time to the proposed program. In addition, a full-time program administrator will be assigned to Mr. Rasband to assist him in the day-to-day activities related to the program.

The Subprogram Project Managers will allocate the following portions of their work hours to the proposed effort:

\section{$\underline{\text { Subprogram }}$}

Power Generation

Mineral Recovery

Reservoir Production

Area Resource Test Facility
Manager

W. C. Racine

C. E. Berthold

B. W. Berthelot

S. Suda $r$
Time

Commitment

$80 \%$

$50 \%$

$40 \%$

$50 \%$

The purpose of the Advisory Committee shown in Figure 9 is to provide a continuing technical appraisal of the program to the Principal Investigator. The Advisory Committee will convene quarterly for program review meetings. Representatives of government, universities, industry and utilities have been invited to participate on the committee. A list of those asked is shown on Figure 10. 


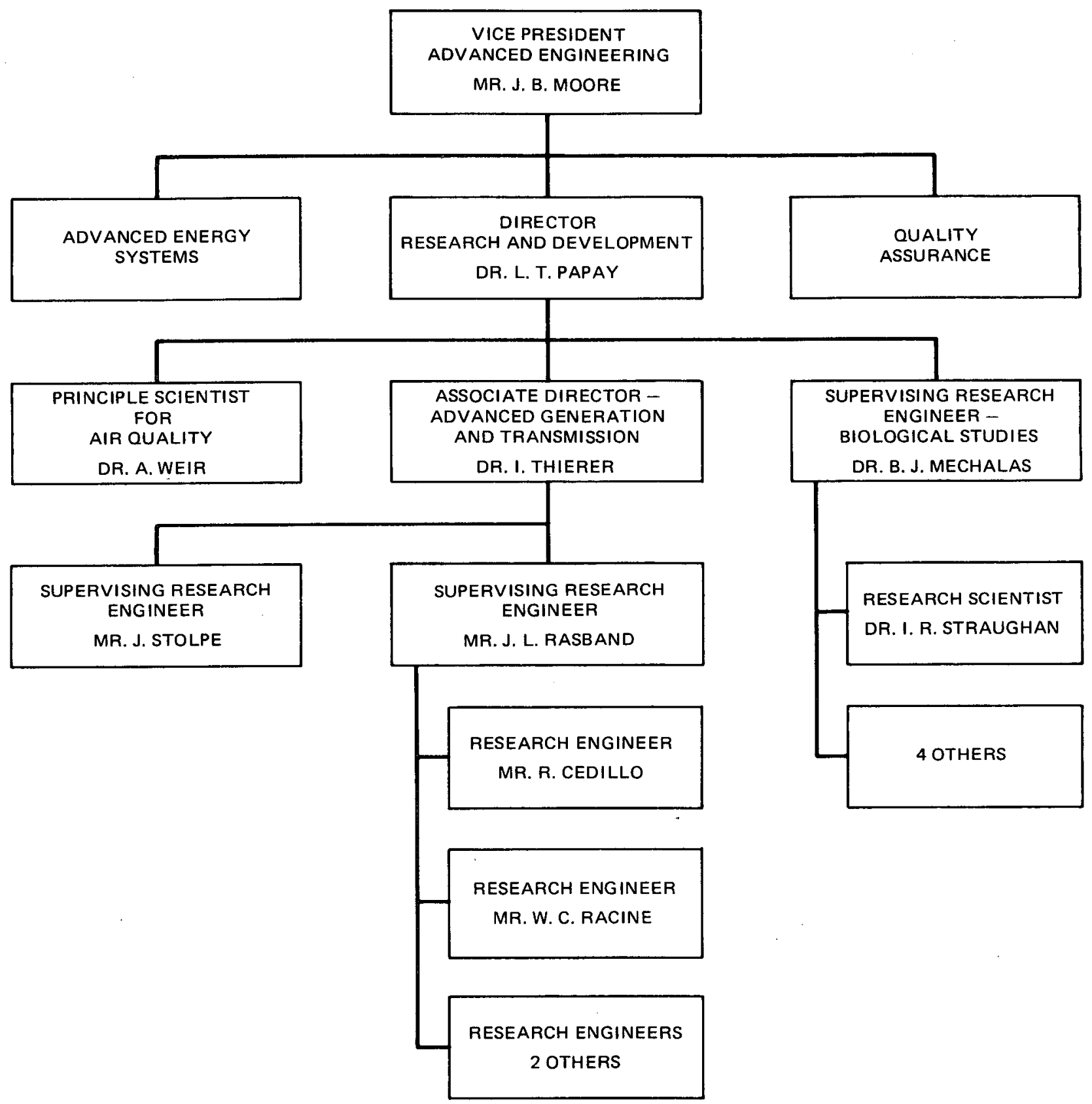

Figure 11. Southern California Edison Research and Development Organization 


\section{b. Management Controls}

Existing and planned techniques developed at SCE to assist in the management of large and complex programs such as electric power production facilities will be available to Mr. Rasband for the proposed program. These tools allow identification of cost, schedule, and performance progress, and comparison with the predicted cost, schedule, and performance.

A computer program currently being developed will be available to Mr. Rasband for the purpose of monitoring cost commitments for labor, travel, materials, and subcontracts on a nearly real-time basis. Based on information obtained from this program, combined with schedule updating done manually by his project administrator and his assessment of technical performance, Mr. Rasband can take action to assure the efficient accomplishment of program objectives.

Subcontractors such as PPC, AI, and Hazen, will be tied to SCE contractually and receive prime direction from Mr. Rasband. Schedule and cost will be managed through the contractual arrangements, and will be constantly compared with technical performance to as sure accomplishment of program objectives. The scope of subcontractors' work will be specified in the contract, and scope changes documented by change orders. Weekly progress reports and monthly program review meetings will as sist in subcontractor manage ment and control.

\section{Functional Organizations Implementing the Program \\ a. Southern California Edison}

The research and Development organization of the Southern California Edison Company has been given the responsibility to conduct the proposed program. The relationship of Mr. Rasband, the Principal Investigator, to the functional organization is shown in Figure 11.

Mr. W. C. Racine, Project Manager for the Power Generation Subprogram, reports to $\mathrm{Mr}$. Rasband functionally as well as on this specific program.

b. Hazen Research

The functional organization of Hazen Research is depicted on the attached Figure 12. In brief, the organization is comprised of about 60 professional, 


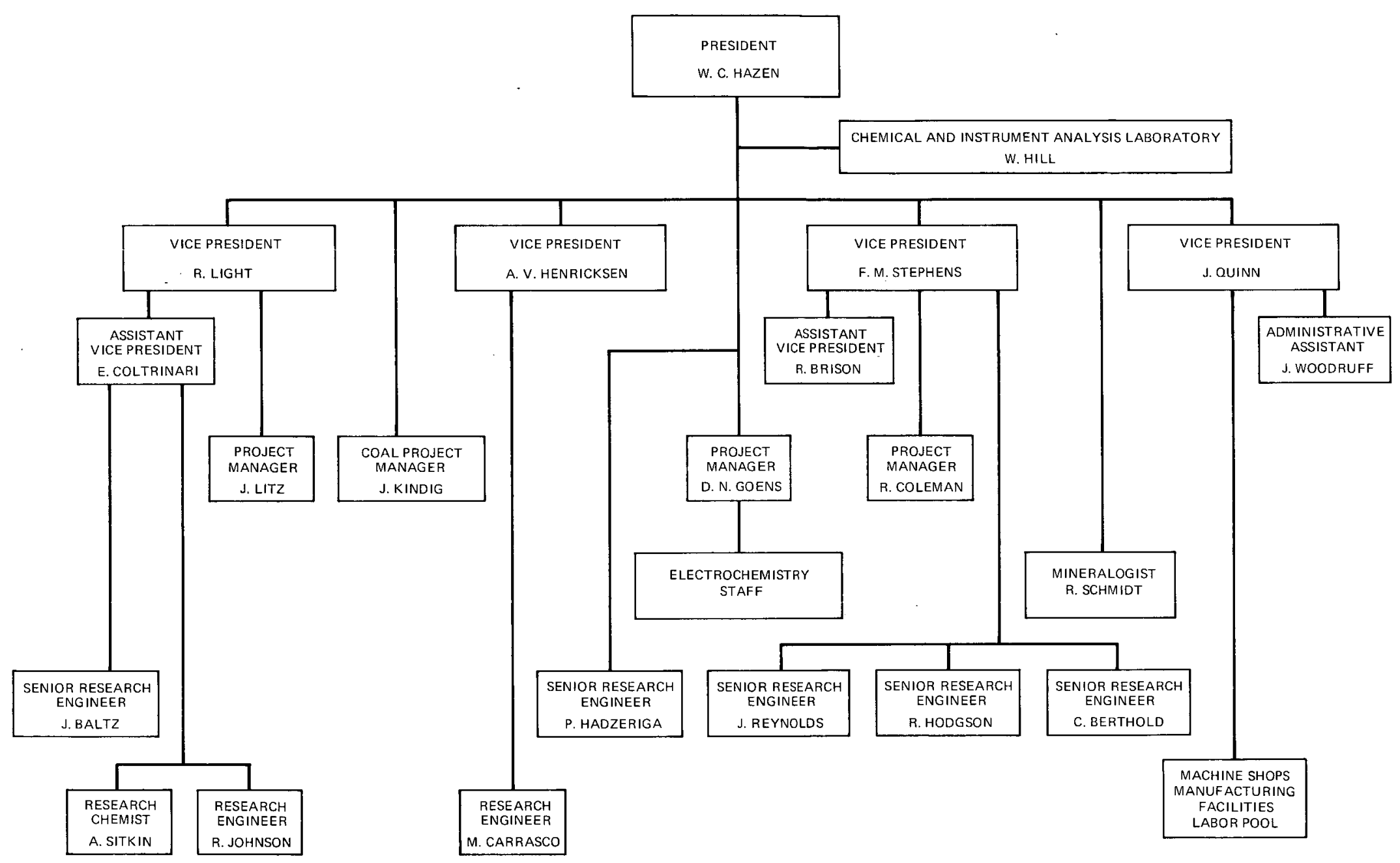

Figure 12. Hazen Research, Inc. Organization 
degreed personnel with approximately 120 support personnel, comprising senior laboratory technicians, electronics technicians, electricians, machinists, welders, boilermakers, laborers, secretarial staff, analytical chemistry department, petrographic and mineralogy staff, and maintenance crew.

Hazen Research Inc. maintains a great deal of flexibility in its organization so that staff can be shifted quickly from group to group as requirements dictate. Thus, while the attached chart shows the organization structure as of today, the entire staff, below the level of vice-president, could be shifted to meet the requirements of a new project.

As presently conceived, the Hazen Research Project Team for the subject minerals recovery studies would include C. E. Berthold and J. M. Reynolds.

\section{c. Phillips Petroleum Company}

The functional organization of Phillips Petroleum Company is shown on the attached Figure 13. Mr. B. W. Berthelot will act as Project Manager, Reservoir Production in the proposed program.

\section{d. Atomics International Geothermal Program Organization}

The Area Resource Test Facility and major segments of the Electric Power Generation subprogram, comprising technology development and power plant design, will be the responsibilities of Atomics International (AI), a Division of Rockwell International Corporation. Figure 14 shows the AI Division organization chart. AI has a central Engineering and Research Department which provides services for all of AI's programs, and Program Offices which provide overall technical direction and schedule and cost control for each major program area. The proposed program areas subcontracted to AI will be assigned to Advanced Programs, managed by W. V. Botts, Vice President.

Advanced Programs is presently responsible for management of several key advanced energy programs including a major coal gasification project jointly supported by the Office of Coal Research, Department of Interior, and the Nor theast Utilities; development of $\mathrm{SO}_{2}$ stack gas scrubbers; development of advanced storage batteries for electric utility load-leveling applications jointly supported by the Electric Power Research Institute and the Argonne National Laboratory; and the design and manufacture of hydrogen recombiners 


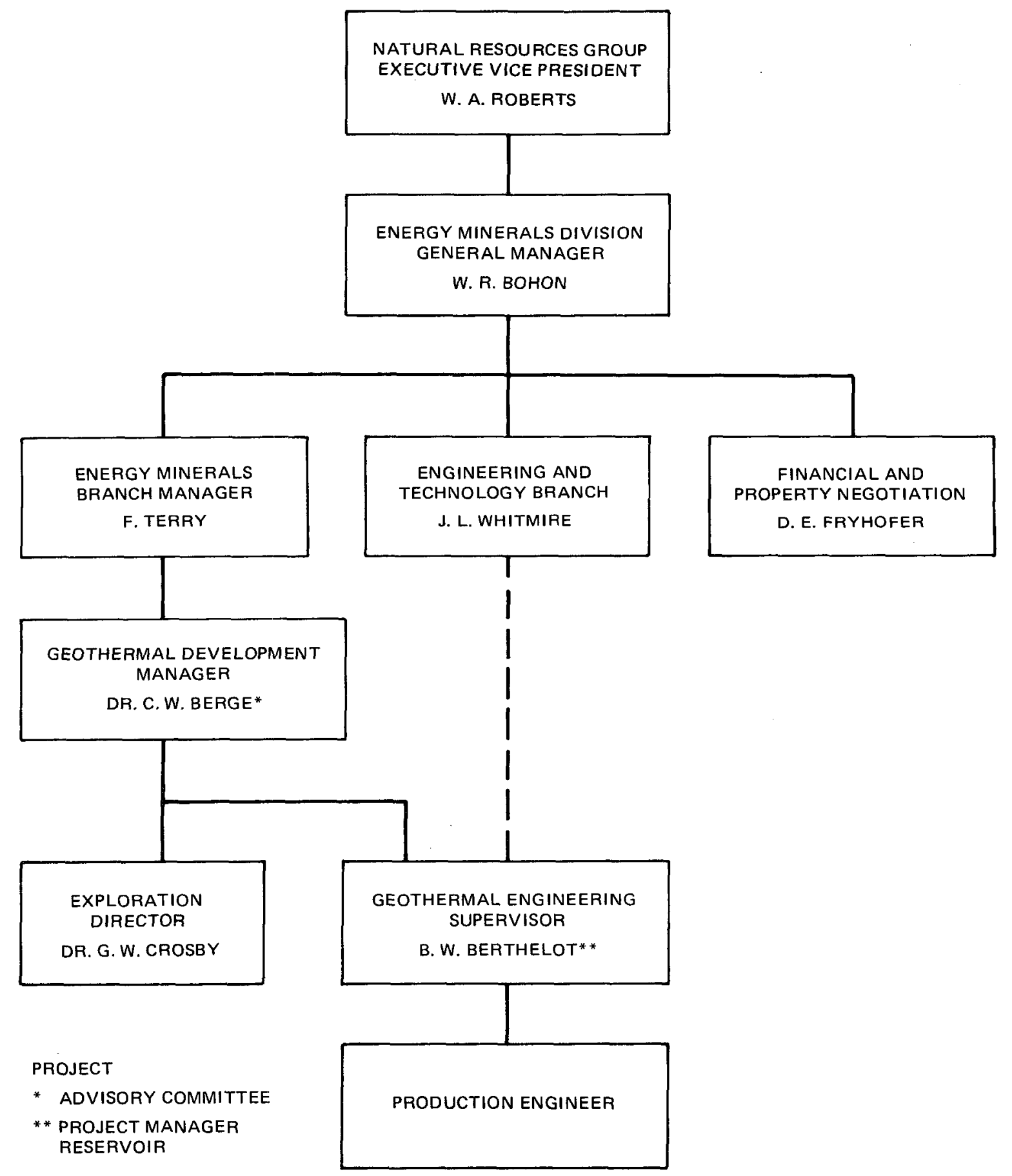

Figure 13. Phillips Petroleum Company Organization 


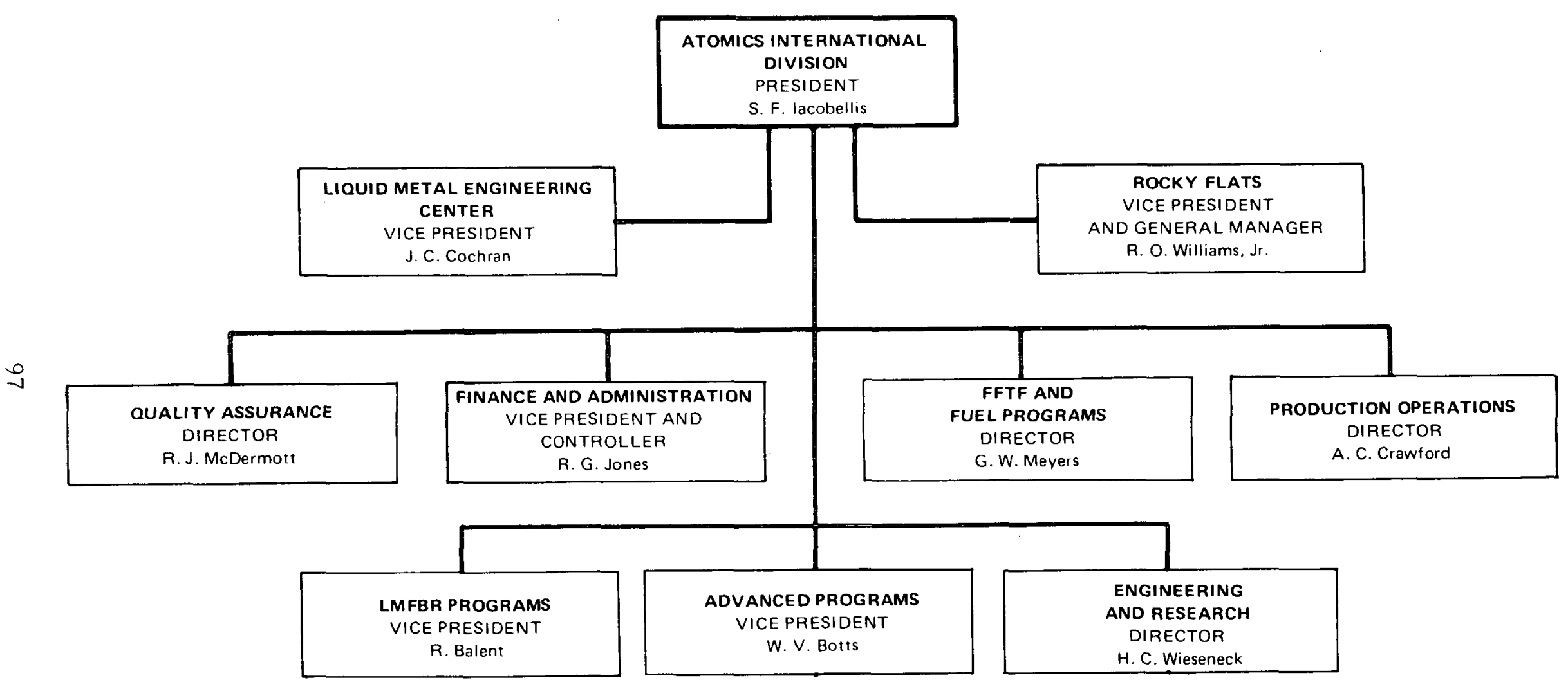

Figure 14. Atomics International Organization 


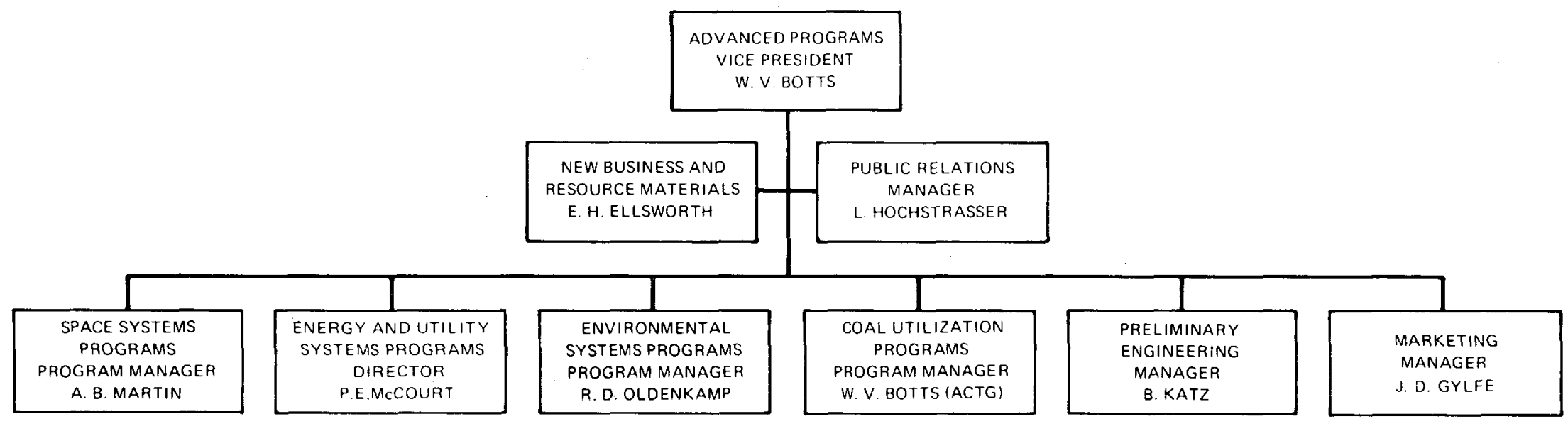

Figure 15. AI Advanced Programs Organization 
for nuclear boiling water reactor and pressurized water reactor safety systems. This program office also currently manages development projects in geothermal and solar energy power generation, air and water pollution control systems, and waste management systems under company-funded programs and under contract to the government and private industry.

Advanced Programs is supported by Engineering and Research, directed by H. C. Wieseneck, and by Production Operations, directed by A. C. Crawford. They will provide expert personnel in the areas of brine chemistry, analytical chemistry, enginee ring design and analysis, facility contracting, shop construction, and quality assurance to implement this program.

The AI Advanced Programs organization is shown in Figure 15. The AI Program Manager for the subcontracted ARTF and electric power generation subprograms will be Mr. S. Sudar, Manager of Energy Systems. He reports directly to the Director of Energy and Utility Systems, P. E. McCourt. Mr. Sudar is experienced in the management of advanced research and development programs. He is currently Project Manager of AI's geothermal power development, solar energy, and advanced secondary battery programs. The 1975 budgets for these programs are approximately $\$ 750,000$.

The project organization to be established for the subject AI program is shown in Figure 16. Reporting to Mr. Sudar will be two Project Managers responsible for detailed technical, budgetary, and schedule control:

Mr. T. H. Springer, Project Manager of Technology Development and the Area Resource Test Facility, and Mr. J. H. Van Osdol, Project Manager of System Engineering and Plant Design. Mr. Springer has over 19 years experience in the field of experimental physics, and in the design, fabrication, and testing of a wide range of physical systems. He recently was responsible for the system design requirements and the conceptual design of a multi-million dollar Reactor Service Building for the Clinch River Breeder Reactor being constructed by the Atomic Energy Commission. Mr. Van Osdol has over 13 years experience in system engineering of electric power generating systems for space and terrestrial application. His experience ranges from design and analysis of multi-megawatt organic-Rankine power systms to thermal and stress analysis of advanced sodium-heated steam generators for the Liquid Metal Fast Breeder Program. 


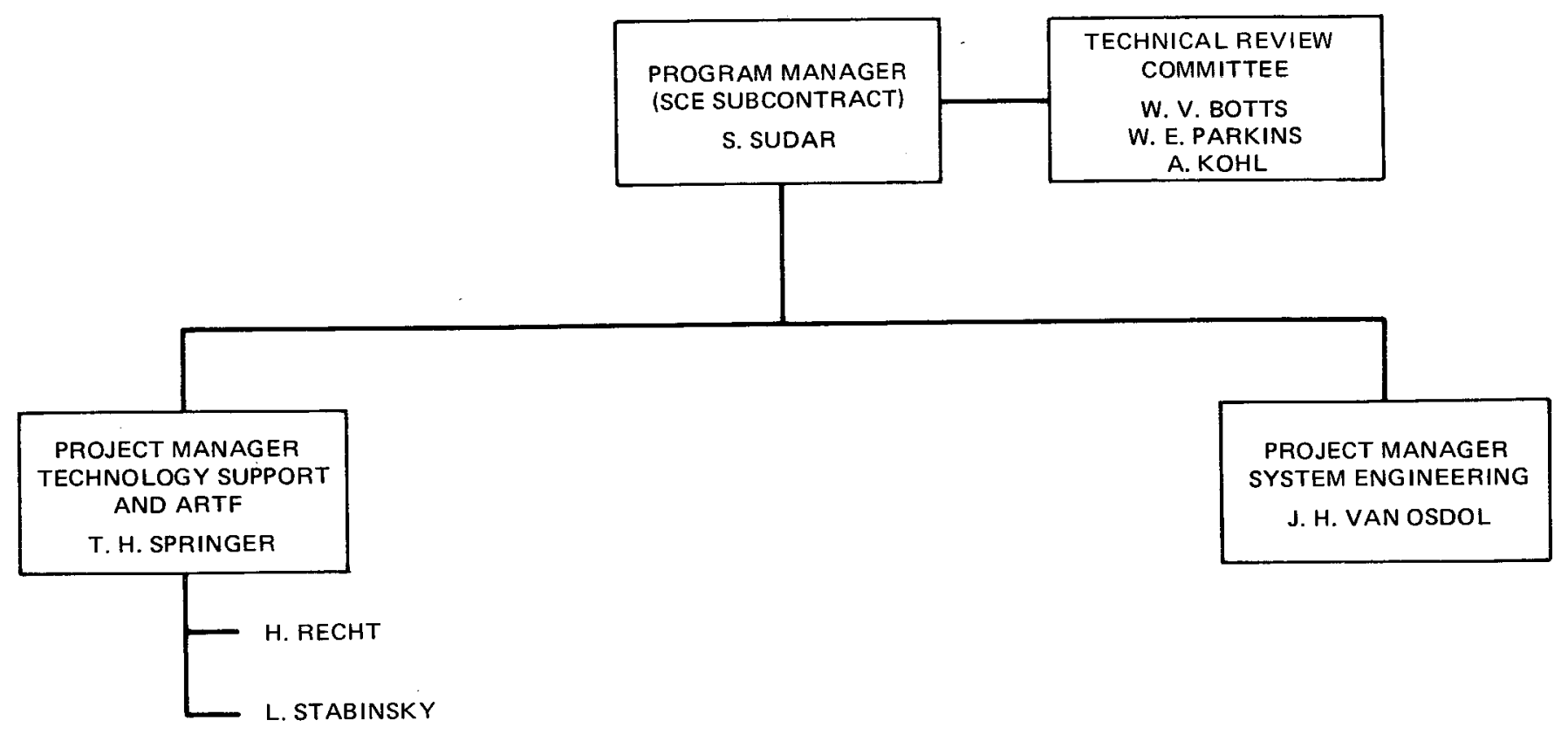

Figure 16. AI Project Organization 
Additional key members of the project team include Dr. Howard Recht and Mr. Leon Stabinsky. Dr. Recht will be responsible for brine chemistry technology, development of scale control processes, and material compatibility studies. He has been performing in this capacity under the Phase 0 Geothermal Power Program subcontracted to AI by SCE. Mr. Stabinsky has served as an AI Project Engineer in the Phase 0 Program, responsible for the design of the steam and brine test modules, design of the Semi-Closed Well Reinjection System, and preliminary cycle analysis. Mr. Stabinsky will be responsible for field test facility construction and operation. Other members of the project organization will be drawn as required from the Preliminary Engineering Group of Advanced Programs (see Figure 15), and from the functional organization shown in Figure 14.

To ensure top management visibility and senior level technical guidance, a Technical Review Committee will be convened monthly to monitor overall progress of the AI activities. This committee will comprise Mr. W. V. Botts, Vice President of Advanced Programs, Dr. W. E. Parkins, Director of Research and Technology, and Mr. A. Kohl, Project Manager of Coal Utilization Programs. Mr. Kohl is a leading process engineer, author of a major book in this field, and pioneer of geothermal power development programs at AI.

The AI Program Manager, Mr. Sudar, will devote at least one-half of his time to the proposed program. The Project Managers, Mr. Springer and Mr. J. H. Van Osdol will be assigned to the program full time. The resumes of Messrs. Sudar, Springer, Van Osdol, Recht, and Stabinsky a re contained in Appendix D.

4. Work Plan

The proposed program will span a period of 20 months culminating with a preliminary design and cost estimate of a pilot geothermal utilization facility.

The program schedule, broken down by subprograms, is presented in Figure 17.

\section{Relationship to Existing Arrangement}

Research and development activities undertaken using Salton Sea KGRA geothermal brines from Sinclair Well 4 since October, 1972 have been performed 


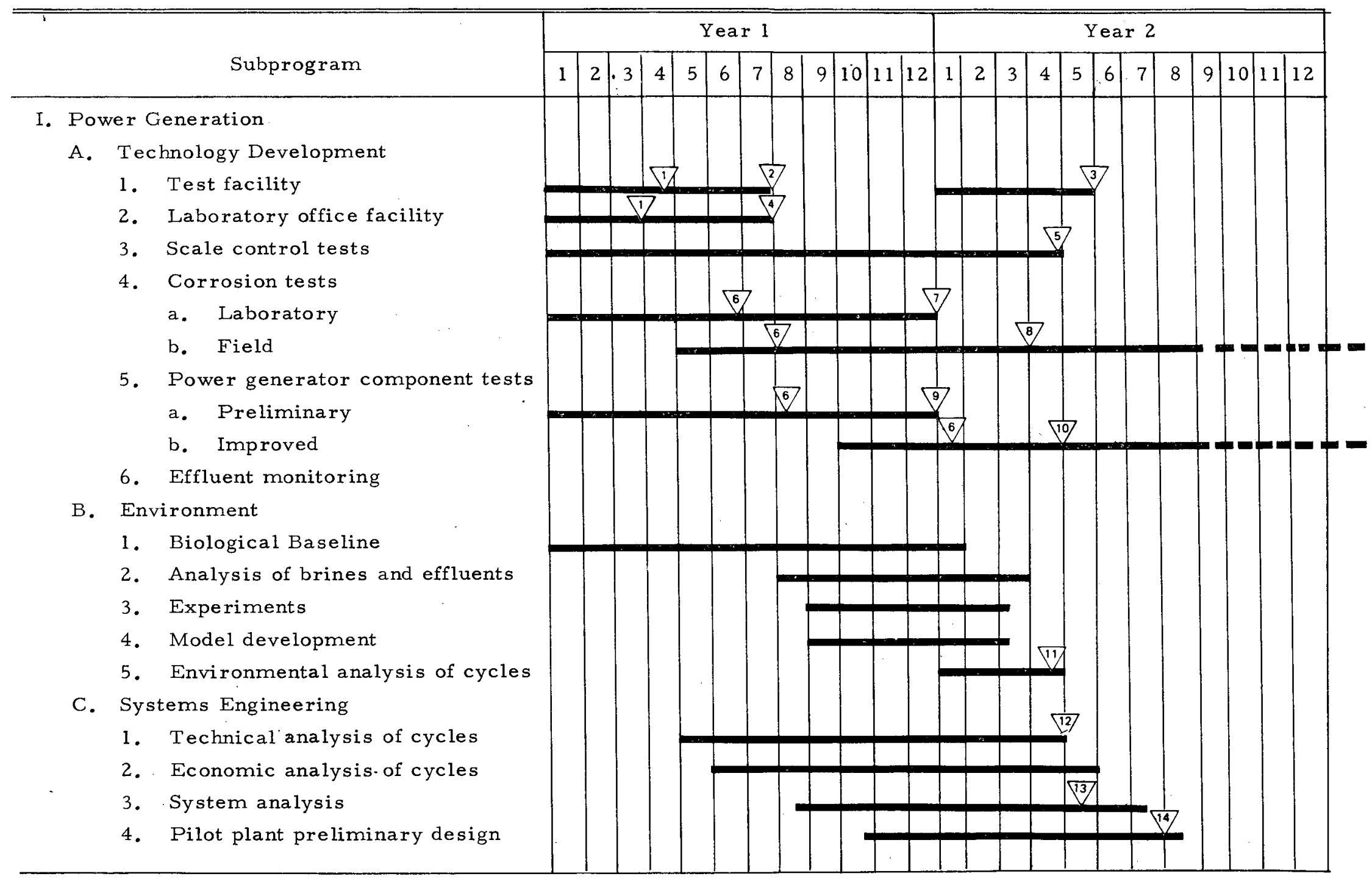

Figure 17. Salton Sea Geothermal Experimental Program Schedule - Phase 1 (Sheet 1 of 4) 


\begin{tabular}{|c|c|c|c|c|c|c|c|c|c|c|c|c|c|c|c|c|c|c|c|c|c|c|c|c|}
\hline & \multirow[b]{2}{*}{ Subprogram } & \multicolumn{12}{|c|}{ Year 1} & \multicolumn{11}{|c|}{ Year 2} \\
\hline & & 1 & 2 & 3 & 4 & 5 & 6 & 7 & 8 & \begin{tabular}{l|l}
9 & 1
\end{tabular} & & 1 & 12 & 1 & 2 & 3 & 4 & 5 & 6 & 7 & 8 & \begin{tabular}{l|l|l}
9 & 10
\end{tabular} & $\begin{array}{l}0 \\
0\end{array}$ & \begin{tabular}{l|l}
12 & 12
\end{tabular} \\
\hline \multirow[t]{21}{*}{ II. } & Mineral Recovery & & & & & & & & & & & & & & & & & & & & & & & \\
\hline & A. Mineral Recovery Facility & & & & & & & & & & & & & & & & & & & & & & & \\
\hline & 1. Select process. & & & & & & & & & & & & & & & & & & & & & & & \\
\hline & 2. Design experimental facility & & & & & & & & & & & & & & & & & & & & & & & \\
\hline & 3. Construct facility & & & & & & & & & & & & & & & & & & & & & & & \\
\hline & 4. Test facility & & & & & & & & & & & & & & & & & & & & & & & \\
\hline & 5. Analysis of results (economic, & & & & & & & & & & & & & & & & & & & & & & & \\
\hline & environmental, technical) & & & & & & & & & & & & & & & & & & & & & & & \\
\hline & $\begin{array}{l}\text { 6. Recommendations and specifications } \\
\text { for pilot facility }\end{array}$ & & & & & & & & & & & & & & & & & 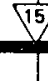 & & & & & & \\
\hline & 7. Pilot facility prelimina ry design & & & & & & & & & & & & & & & & & & & & & & & \\
\hline & B. Brine Cleanup Facility & & & & & & & & & & & & & & & & & & & & & & & \\
\hline & $\begin{array}{l}\text { 1. Define needs and recommend } \\
\text { process }\end{array}$ & & & & & & & & & & & & & & & & & & & & & & & \\
\hline & $\begin{array}{l}\text { 2. "Go ahead" from Reservoir Sub- } \\
\text { program }\end{array}$ & & & & & & & & & & & & & & & & & & & & & & & \\
\hline & 3. Design brine cleanup facility & & & & & & & & & & & & & & & & & & & & & & & \\
\hline & 4. Construct facility & & & & & & & & & & & & & & & & & & & & & & & \\
\hline & 5. Test facility & & & & & & & & & & & & & & & & & & & & & & & \\
\hline & 6. Analysis of results (economic, & & & & & & & & & & & & & & & & & & & & & & & \\
\hline & environmental, technical) & & & & & & & & & & & & & & & & & & & & & & & \\
\hline & 7. Recommendations and specifi- & & & & & & & & & & & & & & & & & 11 & & & & & & \\
\hline & cations for pilot facility & & & & & & & & & & & & & & & & & & & & & & & \\
\hline & 8. Pilot facility preliminary design & & & & & & & & & & & & & & & & & & & & & & & \\
\hline
\end{tabular}

Figure 17. Salton Sea Geothermal Experimental Program Schedule - Phase 1 (Sheet 2 of 4 ) 


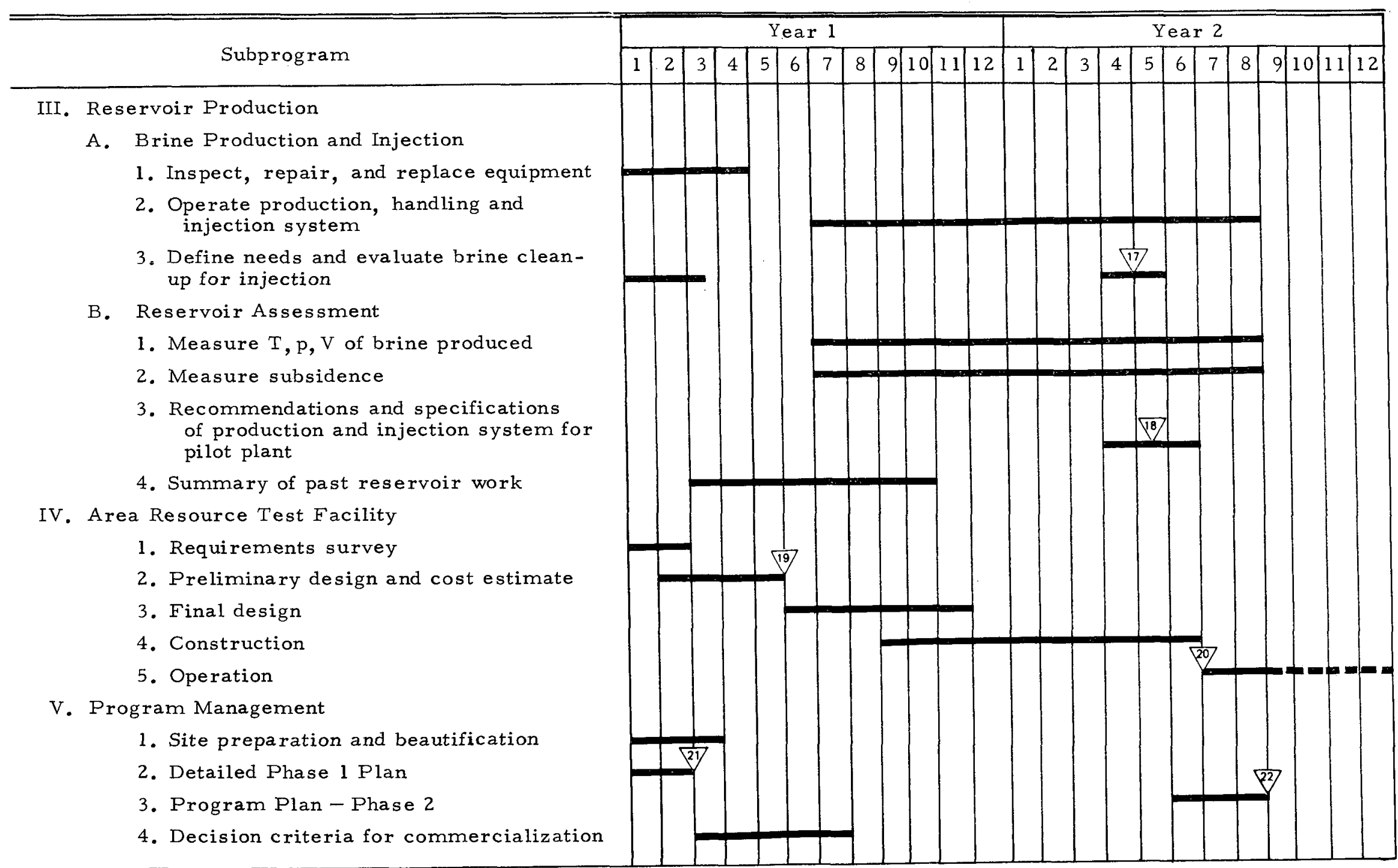

Figure 17. Salton Sea Geothermal Experimental Program Schedule - Phase 1

(Sheet 3 of 4 ) 


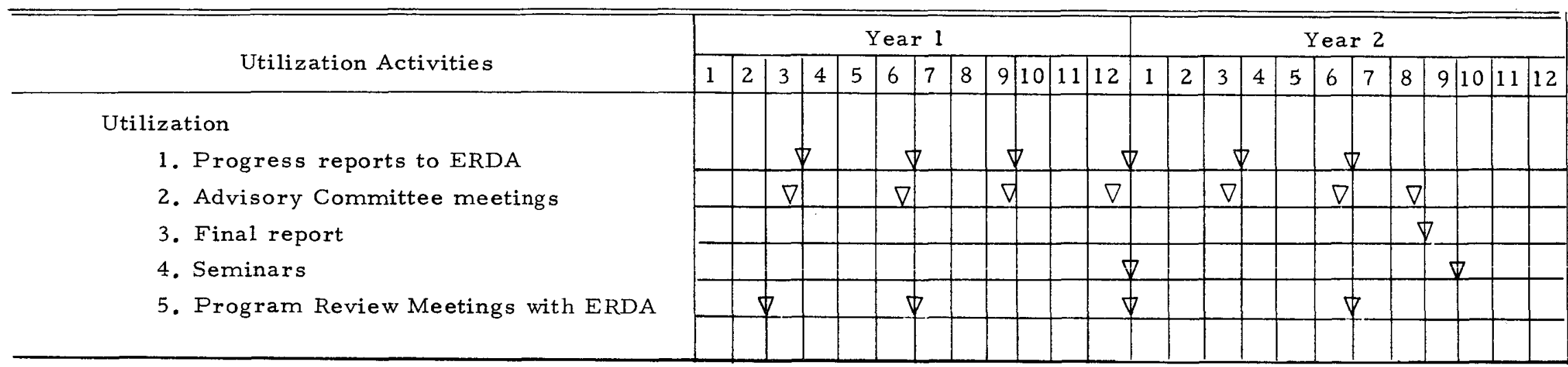

\section{Numbered Milestones (See Pages 102, 103, and 104)}

1. Complete Design

2. Complete Construction of Test Bed

3. Complete Modifications of Test Bed for Binary System Tests

4. Complete Construction

5. Select Scale Control Method

6. Complete Fabrication of Articles to be Tested

7. Complete Laboratory Corrosion Tests

8. Select Materials for Pilot Plant

9. Complete Preliminary Component Tests

10. Preliminary Selection of Cycle Components

11. Cycle Recommendation Based Upon Environmental Impact
12. Select Power Cycle

13. Select Size of Pilot Plant

14. Complete Preliminary Design of Pilot Plant

15. Recommend System for Pilot Plant Mineral Recovery

16. Recommend System for Brine Cleanup

17. Operational Qualification of Brine Cleanup System

18. Recommend Well Production and Injection Systems for Pilot Plant

19. ERDA Review and Approval of ARTF Design and Construction Program

20. Initiate ARTF Operation

21. Complete Phase 1 Program Plan

22. Complete Phase 2 Program Plan

Figure 17. Salton Sea Geothermal Experimental Program Schedule - Phase 1

(Sheet 4 of 4 ) 


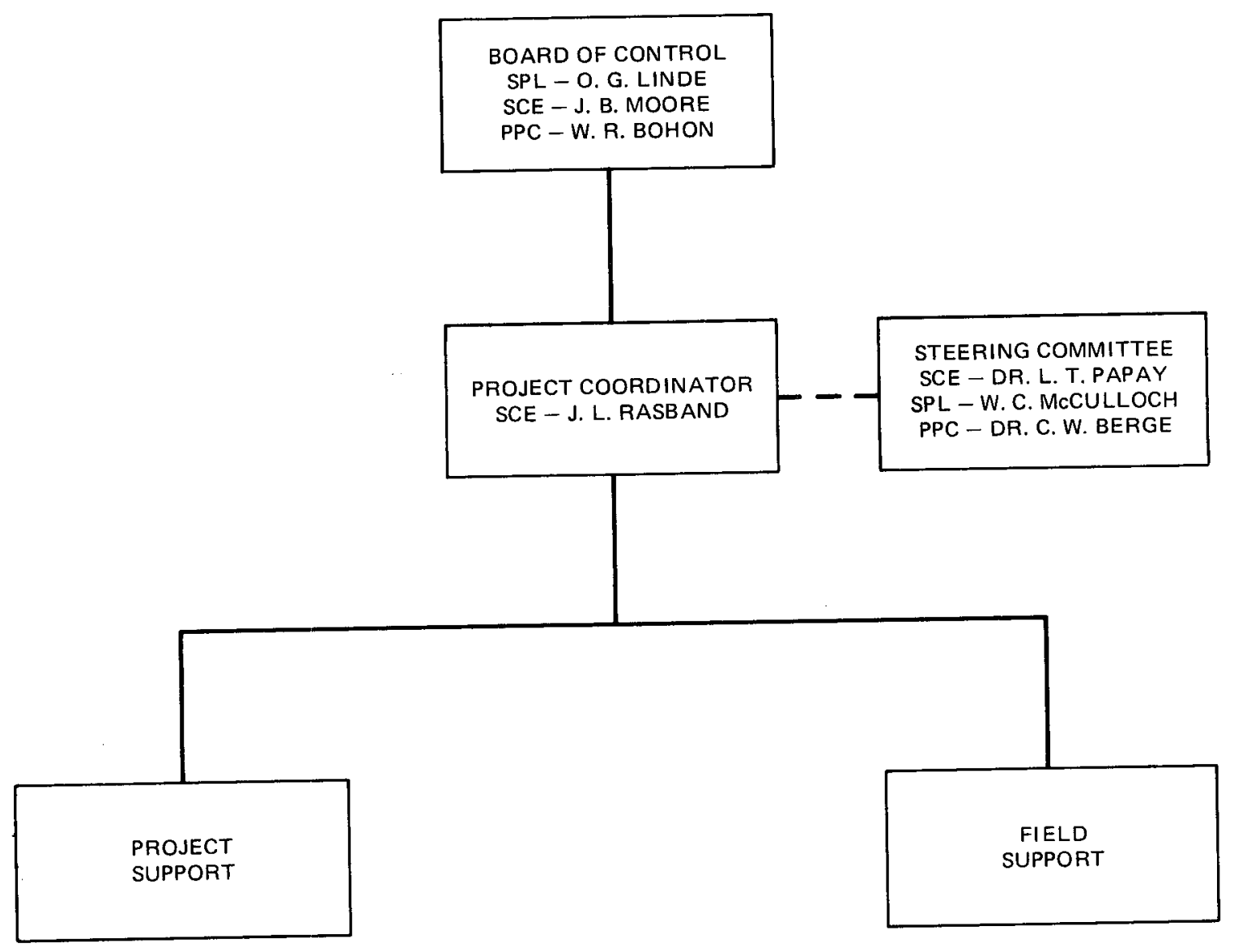

Figure 18. Imperial Valley Geothermal

R\&D Project Organization 
under an agreement among SCE, PPC, and SPL. The work has been designated the Imperial Valley Geothermal R\&D Project. As discussed in Section I-B-2-b, this work resulted in the identification of additional research and development needs, and installation (in progress) of an inter-well brine handling system. The Participants will retain ownership and operating responsibility of the inter-well system during the proposed program.

The inter-well brine handling system will be available on a rental basis to organizations active in development of geothermal brine utilization compoments and systems. At this time, Lawrence Livermore Laboratory and Jet Propulsion Laboratory have expressed an interest in performing tests at the Sinclair 4 site. In addition, the brine and steam necessary for experimental efforts under the proposed SCE-ERDA program will be supplied from the brine handling system.

Should more than one user require the brine handling system simultaneously, the costs of operating the system will be shared among the users.

In order to assure the proposed program receives priority use of the interwell system, the Principal Investigator for the proposed work has also been designated Project Coordinator for the Participants. The Project Coordinator has the authority to act in behalf of the Participants. In this manner, the accomplishment of program objectives regarding cost, schedule, and performance will be assured.

The organization chart for the Imperial Valley Geothermal R\&D Project is shown in Figure 18. The Field Activities Coordinator will be responsible for operating the interwell system for the Participants under the direction of Mr. Rasband, the Project Coordinator. Because Mr. Rasband also has overall responsibility for the proposed ERDA program, he will be able to assure proper coordination of the two organizations to allow accomplishment of program objectives.

It will be noted that $\mathrm{Mr}$. Rasband is responsible to the Board of Control of the Imperial Valley Geothermal R\&D Project. Because of this reporting responsibility, the program contained in this proposal has been approved by the Board of Control. 


\section{UTILIZATION PLAN}

The utilization of results obtained from the proposed program will be an integral part of the program. An organized effort will be made to communicate program results to those individuals and groups involved in geothermal utilization efforts of the kind being undertaken in this program.

1. User Group Identification

\section{a. Research Directed Toward Pilot Plant}

The proposed subprograms entitled Power Generation, Mineral Recovery, and Reservoir Production which are designed to allow expeditious development of a pilot geothermal utilization facility will produce results which should be of interest to the following organizations:

\section{Organization}

Electric Power Research Institute *San Diego Gas \& Electric Co.

*Imperial Irrigation District

Other Utilities in Southwest

Bechtel Corporation

*Ben Holt Company

C. F. Braun \& Co.

*County of Imperial

*State of California

Bureau of Land Management

National Science Foundation

Energy R\&D Administration

Bureau of Mines

*Morton, Norwich, Inc.

* Magma Power Co.

Union Oil Co.

Chevron Oil Co.
Field of Interest

Power Generation

Power Generation

Power Generation

Power Generation

Power Generation

Power Generation

Power Generation

Overall Program (especially

Environmental Impact)

Overall Program (especially

Environmental Impact)

Overall Program (especially

Environmental Impact)

Overall Program

Overall Program

Mineral Recovery

Mineral Recovery

Reservoir Assessment

Reservoir Assessment

Reservoir Assessment

*Representative of organization asked to serve on Advisory Committee. 
In addition to the above organizations, two presently funded NSF grantees, Bechtel Corporation and TRW, are engaged in Phase 0 geothermal programs. These efforts will result in site selection for proposed research programs leading to pilot geothermal-electric power plants. The results of the SCEERDA program will provide useful information to these investigators.

\section{b. Area Resource Test Facility}

At the present time, a number of organizations can be identified who would be most interested in utilizing the Area Resource Test Facility to be constructed during the program.

The following is a partial list of organizations and their corresponding field of geothermal activities:

Lawrence Livermore

Laboratory

Lawrence Berkeley

Laboratory

Los Alamos Scientific

Laboratory

U.S. Bureau of Mines

Bureau of Reclamation

U. S. Geological Survey

Jet Propulsion Laboratory

National Bureau of

Standards

Garret Research \&

Development Company

Ben Holt Co.

University of California at Riverside

University of Texas
Total flow turbomachinery barometric condensers

Brine chemistry

Geochemistry and geophysical

measurements

Mineral resources, corrosion and materials evaluations

Brine chemistry, water management, environmental studies, reservoir engineering

Geochemistry, reservoir engineering, energy assessment, geophysics

Helical screw rotary expander (Hydrothermal Power Co.)

Brine chemistry, multiphase flow calibrations (flowrate, temperature, and pressure measurements)

Scaling studies

Evaluation of separators and scrubbing equipment, heat exchanger testing

Geophysics, geochemistry, reservoir as ses sment

Geophysics, geochemistry, reservoir as ses sment 
University of

Southern California

General Ener-Tech Co.

Sperry Research Center

Geo-Energy Systems Inc.

Imperial Irrigation

District

Electric Power Research Institute
Reservoir engineering

Bladeless turbine

Pumps

Testing of heat exchangers

Water management, subsidence

Evaluation of potential power producing methods

It is anticipated that private and publicly owned utilities located in the Western United States presently active in developing geothermal energy may also be seeking use of the ARTF.

The extent of the geothermal fields of the Salton Sea KGRA, and the potential economic impact of their utilization, create a need for the ARTF. While known problems remain to be solved, many designs and concepts are now in existence, awaiting demonstrations and controlled tests. Solutions of these problems and demonstrations require geothermal flows and experimental facilities which will be provided by the ARTF.

\section{User Demand Description}

The results of Power Generation, Mineral Recovery, and Reservoir Production activities will be available to aid potential developers and users of other geothermal brines. Because of the high solids content of the Sinclair 4 brines to be used in this program, many of the experimental results and techniques will be generalizable to other geothermal resources. In addition, the ecological modeling techniques developed will be designed for application to other major developments. For example, the models developed may be of use to the mining, oil exploration, resort development, power plant construction, and process industries in predicting the ecological impact of major developments.

The Area Resource Test Facility is expected to be of use to many organizations, some of which were mentioned in Section I-Dl, in the development of geothermal utilization equipment and processes. 


\section{Utilization Process Description}

The process for dissemination of results will include four major methods: reports to ERDA, technical papers in open literature, progress reports submitted to the Advisory Committee, and seminars to be held for potential users.

\section{a. Reports to ERDA}

Quarterly progress reports will be submitted to the ERDA Project Manager in order that he may assess program results on a continuing basis. Test data taken during the program will be released in these and other reports to ERDA. In addition reports will be submitted on the following:

Detailed Program Plan

Preliminary Design of ARTF

Completion of Construction of ARTF

Power Cycle Selection

Mineral Recovery Process Selection

Final Program Report

b. Technical Papers

Each subprogram manager will be responsible for preparing papers to be delivered at technical society meetings, and/or published in the technical literature.

\section{c. Advisory Committee}

The quarterly progress reports submitted to the Advisory Committee will assist greatly in dissemination of results. The committee members, by discussing the program among themselves and with their associates in the technical community, will serve as an important communication conduit for the program results. Some members of the program Advisory Committee are also members of the Geothermal Industry Liaison Group. It is anticipated that these dual membership responsibilities will also aid in dissemination of program information to potential users. 


\section{d. Seminars}

The proposed program will include two user seminars. The first will occur at the end of the first year of program activities. Discussions will cente $r$ around program progress as of that date, and preliminary conclusions reached will be discussed. The seminar will include a field trip to the program site.

At the close of the program, the Principal Investigator will organize a second seminar for the purpose of communicating program results to the geothermal community. This seminar will include a detailed program chronology, discussion of research results, and a field trip to the program site. It is anticipated that each seminar will include 2 days of discussion and a l-day field trip.

\section{Utilization Budget}

The budget for utilization activities is included in the Budget Section of the proposal. 


\section{E. RELATED PROGRAMS AND ACTIVITIES OF THE ORGANIZATIONS}

\section{Southern California Edison Company}

Southern California Edison (SCE) is an electric utility which has been operating continuously for over 80 years. During that time it has designed, constructed, and operated numerous major facilities ranging from hydroelectric plants to nuclear and coal-fired steam generating stations. In the past decade, these facilities have grown in both size and financial requirements to current plants of 3000-MW capacity with project costs in excess of $\$ 2$ billion. SCE has grown in manpower and, more importantly, in experience to meet the challenges posed by these projects. This experience and associated knowledge has been recognized in the choise of SCE as project manager for a series of major generating facilities using both nuclear and coal fuel since the late $1960^{\prime}$ s and continuing into the $1980^{\prime}$ s.

In addition, over the past 20 years, SCE has been involved in many programs for the development of new concepts. In the past 5 years, SCE has served as project manager for multi-utility programs requiring research efforts to establish technical feasibility of new technologies and continuing through the design, construction, and operation of demonstration facilities to commercial utilization of the technology. As air quality regulations have been made more stringent, SCE has had to develop expertise in the chemical processing area to be able to design and engineer cleanup systems for power plant emissions. The scarcity and high cost of low-sulfur oil has caused a strengthening of this expertise and participation in refinery design and construction has become important. Thus, SCE has obtained and can utilize a broader range of backgrounds, experience, and knowledge than electric utilities traditionally have had in the past.

Design and construction of all of the operating facilities and demonstration projects have required interdepartmental cooperation within SCE, coordination of SCE and contractor activities, and coordination of multi-owner or multiparticipant interests in the project.

A description of recent and ongoing relevant projects follows. 


\section{a. Mohave Generating Station}

The Mohave Generating Station, consisting of two 755-MW, coal-fired, steam generating units is jointly owned by Southern California Edison, Los Angeles Department of Water and Power, Nevada Power Company, and Salt River Project. SCE was chosen to manage the design and construction of the plant and to operate it when it was completed. This facility was put into commercial operation in 1971 at a cost of approximately $\$ 200$ million. One novel feature of the facility is the use of coal which has been transported 275 miles to the plant in the form of a slurry.

As project manager for this plant, SCE increased its technical experience in coal and coal slurry handling, water treatment, process systems, and solid, liquid, and gaseous waste handling.

b. San Onofre Nuclear Generating Station, Units 2 and 3

San Onofre Units 2 and 3 are each 1140-MW, pressurized-water nuclear generating plants which will be owned by Southern California Edison and San Diego Gas and Electric. SCE is the design and construction manager and, after startup in 1979 and 1980, will be the operating agent. Total project cost for which SCE has responsibility is in excess of $\$ 1$ billion.

SCE will contract with an Engineer-Constructor organization for the principal services required for design and construction of the units but will retain responsibility for procurement of most major equipment. Several contracts will be issued to firms other than the Engineer-Constructor for specialized products and services. SCE will be responsible for managing all contracts as well as performing certain design and engineering efforts in-house. The SCE construction management associated with the project includes the plant startup effort.

This project represents a use of SCE project management and technical experience for extremely large and sensitive projects with extensive quality assurance requirements.

c. Kaipa rowits Generating Station, Units 1-4

The Kaiparowits plant is to consist of four 750-MW pulverized-coal-fired steam generating units scheduled for operation in the early $1980^{\prime} \mathrm{s}$. In addition 
to SCE, other participants include Arizona Public Service and San Diego Gas and Electric. SCE is the project director responsible for the performance of all engineering, design, construction, management, testing and startup of the facility. SCE is also the operating agent for the station. It is currently estimated that total project costs will be in excess of $\$ 2$ billion.

The Kaiparowits Power Project will be designed and constructed utilizing the Project Management concept. Additionally, the matrix management concept will be employed commensurate with the project phases.

\section{d. Mohave $\mathrm{SO}_{2}$ Scrubbers}

In order to comply with local air quality regulations and because of the lack of adequate technology, SCE undertook the devepment of $\mathrm{SO}_{2}$ scrubbers for the Mohave and Navajo Generating Stations. With SCE as the program manager, eight different scrubber concepts including one conceived by SCE, were tested in pilot plant size. The Edison scrubber and one other were selected for further testing in demonstration plant size. SCE contracted with architectengineer organizations for the final design and construction of these units and is currently conducting the demonstration tests along with alternate subsystem equipment at the Mohave Station. At the conclusion of these tests, SCE will choose the best scrubber and the best subsystems and plans to manage the installation and operation of the facilities at the Mohave Station.

This project required SCE to manage efforts from the research phase beginning in 1971 through design, construction, and operation of demonstration facilities to installation of commercial scrubber equipment by 1976 . As a byproduct to the main project, extensive experience has been gained in the handling of waste products and chemical process systems.

\section{Atomics International}

The Rockwell International Corporation evolved from a merger in 1967 between North American Aviation, Inc. and the Rockwell Standard Corporation. This large, highly diversified organization registered over 4 billion dollars in sales in 1974. Its activities range from the production of military and commercial aircraft to microelectronic components and computers, nuclear reactors 
and components, to knitting machines and printing presses, the building of the spacecraft and rockets for putting a man on the moon, to the production of wheels and axles for trucks and trains.

Atomics International (AI) is an operating Division of the Corporation. AI has been engaged in research, development, engineering, manufacturing, construction, and test operations in a number of advanced technology areas since 1946. The main thrust of this activity was initially directed toward the application of nuclear energy for central station electrical power plants and for space electric power systems. More recently, AI has been a major contractor for the Liquid Metal Fast Breeder Reactor Program, a developer of systems for removing $\mathrm{SO}_{2}$ from stack gases, a supplier of nuclear power reactor systems and services, and actively involved in geothermal and solar energy research and development.

AI pioneered liquid-metal-cooled reactors with the Sodium Reactor Experiment (SRE) which was put into operation in 1957. This was followed by a larger, 75, 000-kWe, sodium-cooled reactor power plant which went into operation in Hallam, Nebraska, in 1963. Two unique reactors using an organic coolant were also built and operated during this same time period. The space nuclear electric power program was highlighted by the world's first successful launch, remote startup, and operation in space of a nuclear reactor power system, SNAP 10A, in 1965. The technology and experience gained from these projects is currently being applied to the Liquid Metal Fast Breeder Reactor (LMFBR) Development Program at AI as well as to a host of advanced energy and pollution control projects.

The successful conduct of these programs has, of necessity, required the establishment of a strong capability in the fundamental physical, chemical, and material sciences as well as in basic design, process engineering, and manufacturing. AI has nearly 1600 employees, including 950 professional and technical personnel; approximately 740 having bachelor or advanced degrees. Extensive facilities have been developed to support diverse programs. These facilities are composed of engineering and administrative offices, research and development laboratories, machine shops, and fabrication facilities. They include more than $405,000 \mathrm{sq} f t$ of covered floor area at the Canoga Park, 
California headquarters complex, and 154,000 sq ft in AI's Nuclear Development Field Laboratory, located in the nearby Santa Susana Mountains.

AI now has active research and development programs in air and water pollution control, coal gasification, and advanced energy systems. These programs include an aqueous carbonate process for removing $\mathrm{SO}_{2}$ from stack gases; a molten carbonate process for the gasification of coal; molten carbonate processes for the disposal of pesticides and for the recovery of silver from photographic film; experimental diesel and auto exhaust emission control devices which also use molten carbonate technology; desalination of brines; solar and geothermal power generation; an electrochemical process for removing heavy metals from water; and development of high performance nickel-zinc and lithium-sulfur rechargeable batteries for utility energy storage and electric vehicle applications.

The sections which follow present $\mathrm{AI}^{\prime}$ s experience and capabilities as they relate to this proposal.

a. Geothermal Studies

AI has been and is currently engaged in geothermal studies, primarily in the areas of the control of scaling from brines, brine handling and re-injection, component testing, and power cycle selection. These studies are sponsored by the Southern California Edison Company and are directed specifically toward the use of the high salinity brines in the Imperial Valley geothermal area. A portion of this program, termed Phase 1, has been completed. Phase 1 included: (1) a technical review of available data on the operation of a specific well in the Imperial Valley Area insofar as corrosion of power generation equipment and incidence and control of scale deposition was concerned; (2) the conceptual design of energy extraction test equipment; and (3) a preliminary screening of power generation cycles.

Three geothermal projects, sponsored by SCE or the three-party consortium, and directly concerning the utilization of Imperial Valley geothermal resources are currently underway at AI. One of them, designated Phase 2, comprises the detailed design of energy extraction test equipment to be located at Sinclair No.4, as well as studies of the performance of small-scale laboratory corrosion experiments, primarily in support of the test equipment design. The 
energy extraction test equipment design includes brine and steam test facilities to: (1) evaluate scale deposition, (2) test proposed scale control methods, (3) evaluate corrosion of components and equipment for steam-brine separation, and (4) evaluate proposed steam purification methods. This design program is nearly complete and a final report is in preparation.

A second project designated Phase 4 is being initiated at this time and consists primarily of the fabrication and installation of a brine handling and injection system to be used in association with test modules provided by interested organizations.

A third project that is also underway consists of more detailed evaluations of scale control methods. The primary objective of this program is to provide a better understanding of fundamental factors influencing the deposition of scale from geothermal brines. Secondary objectives include the screening of proposed deposition control techniques and the evaluation of methods for removing scale after it has formed. For this work, a small-scale laboratory apparatus has been designed and assembled to provide a flow of hot, silica-laden, air-free brine to a scale deposition testing zone. With this equipment, the effect of surface material and finish, fluid dynamic conditions, chemical characteristics, and other parameters of the deposition process are being evaluated. Promising scale deposition control methods will be given initial laboratory testing within this program.

In addition to these three programs, AI is funding a project to augment studies of the factors influencing scale formation and corrosion in geothermal high temperature, high salinity brine systems, and to investigate novel methods of scale prevention and control.

b. Saline Water Conversion Programs

(1) DCC-MSF Process Development

Under a series of Company and OSW-sponsored tasks, AI has developed a Direct Contact Condensation-Multistage Flash Process for Saline Water Conversion. Work on this program involved both engineering studies and pilot-scale tests. Field tests were carried out by AI personnel at the Office of Saline Water Test Facility, Wrightsville Beach, North Carolina, and the Millstone Point Test Station of AMF Cuno Division to augment activities carried on at AI's home plant. 
The test program involved heat transfer, corrosion, scale deposition problems, hydraulics, and the performance of special equipment. This program included conceptual design and economic evaluation of a large DCC-MSF distillation plant incorporating 25 flash stages.

\section{(2) Prescaling Studies}

Another program worked on at AI under OSW sponsorship (OSW Contract No. 14-01-0001-1681) was the Study of Prescaling Deposition. This involved a study of the chemistry and physics of the induction period usually observed in the heterogeneous nucleation of heat exchanger scale. Knowledge of absorption processes preceding nucleation and scale deposition was shown to be the key to understanding of the scale formation process; use of radioactive tracers provided a unique tool to gaining this knowledge. The test program involved measuring deposition of scale on simulated heat exchanger surfaces as a function of time, temperature, and concentration, using the radioactive tracer calcium -45 . In the latest phase of the program, calcium sulfate absorption was found to depend on $\mathrm{pH}$, the rate being greater at a $\mathrm{pH}$ of 6.5 than at a $\mathrm{pH}$ of 4.5 . Smooth surfaces were shown to inhibit scale formation. Surprisingly, absorption of the calcium-45 species was enhanced by scale-inhibiting additives which act by complexing with the $\mathrm{Ca}^{+2}$ ion; as expected, it was reduced by those additives which act by forming protective films on the metal surface.

\section{c. Aqueous Process Programs}

Atomics International has been performing consultation services to the BSP Division of the Envirotech Corporation on scale and corrosion problems in their Heat Treatment Process. This process for conditioning sewage sludges for better filtration involves heating and steam treating the sludge in a heat exchanger and reactor, followed by cooling in the heat exchanger. Scale formation problems were identified and several promising approaches to dealing with these problems were formulated. Several of these solutions were given successful laboratory testing at AI. Seawater infiltration into coastal sewage lines presented a corrosion problem in such treatment of saline sludges. AI evaluated the problem, did confirmatory laboratory corrosion tests and made recommendations to Envirotech for their coastal plants. 
AI has made extensive and detailed engineering economics studies of dualpurpose, nuclear power plants involving large, multistage flash distillation plants. Design and performance characteristics of multistage flash distillation plants having a capacity of up to $1000 \mathrm{mgd}$ have been derived.

A computer code has been developed at AI to facilitate the analysis of multistage flash distillation systems. The code is separated into two sections; the thermodynamic section and the economics section. The thermodynamic section gives a material and energy balance on the train of evaporator stages. Based upon a specified number of stages and given terminal temperature differences, the code specifies the major plant design characteristics such as condenser heat transfer surface, brine heat transfer surface, and pumping power. The economics section gives the various costs associated with the train just analyzed. The cost contributions are based on specified unit cost data for process heat, electrical energy, and various capital and operating cost items.

\section{d. Heat Exchangers}

Atomics International has been involved in the design and fabrication of several large heat exchangers, the principal one being the 30-Mwt modular steam generator (MSG) for the LMFBR program. A major capability in design tools and manpower therefore exists at AI for designing heat exchangers of all types, and a basic technology has been established. Two other notable heat exchanger programs are the Fuel Element Failure Propogation Loop (FEFPL) and Rocket Engine Exhaust.

\section{e. Organic Working Fluids}

AI has acquired extensive experience and conducted numerous studies and tests in the area of the application of organic working fluids to the production of mechanical and electrical power. Two complete reactor systems using organic working fluids were designed, developed, and operated. One, the Organic Moderated Reactor Experiment, was a 5-MWt system that was operated at the National Reactor Testing Station. The other, the Piqua Nuclear Power Facility, was a 45-MWt system operated by AI for the city of Piqua, Ohio, for use in the commercial production of electrical energy.

More recently, AI has performed investigations of organic Rankine power systems. These applications include $400-\mathrm{w}(\mathrm{e})$ radioisotope systems for space 
unmanned reactor systems in the range of 2 to $25 \mathrm{kWe}$, space station systems from 25 to $100 \mathrm{kWe}$, terrestrial systems from 100 to $500 \mathrm{kWe}$, and underwater oil pumping stations of $3.0 \mathrm{MWe}$. Studies have been made of organic Rankine systems using a variety of working fluids including Dowtherm A, diphenyl, toluene, monoisopropylbenzene (MIPB), thiophene, and several others.

\section{f. Thermal and Process Analysis Capability}

Atomics International, in the course of its development efforts in a broad range of advanced technology areas, has developed a high level of analysis and design capabilities for advanced and/or novel components and systems. The Thermal and Process Systems Group, which performs the thermal and process analysis and design activities within the Research and Engineering Department comprises over 200 manyears of experience in a group of about 20 engineers (through Ph.D. level). Additional analysis and design capabilities for thermal systems exist within the System Engineering and Preliminary Design Groups.

A key element of this technical capability is the comprehensive array of computer programs applicable to the design, analysis, and evaluation of all aspects of thermal and process systems. These computer programs include the Differential Equation Analyzer Program (DEAP) which is a versatile, convenient program which incorporates an extremely efficient integration scheme to solve multi-dimensional problems in heat transfer, fluid flow, mass transfer, vibration, etc. A special fluid flow option allows treatment of transient heat exchanger problems in a straightforward manner including two-phase fluid characteristics, and special purpose subroutines allow solution of mass and energy transfer due to boiling from a liquid-vapor surface as well as chemical reactions within the system.

Other computer programs in these areas include the Thermal Analyzer Program (TAP), a version of which is included in the Rockwell timeshare library; SOMIX, a two-dimensional program for calculating combustion effects and heat transfer for liquid sprays in gases to determine gas temperatures and internal gas circulation within equipment vaults. Several programs utilized for hardware design include the Multipass Tubular Heat Exchanger Design Computer Program; Module 1, 2, and 3 for steam generator design evaluation and part load or offdesign performance predictions; Gas-side Heat Transfer Coefficient $\left(\mathrm{H}_{\mathrm{g}}\right)$; and SETS and STAMP, which are used for steam generator analysis and interfacing 
of thermal and stress computations; and Atomics International subscribes to the Heat Transfer Research, Inc. Service which provides a broad range of proprietary information on thermal systems and equipment analysis and design.

\section{g. Manufacturing}

The AI shop can fabricate large and complex items to exacting specifications. However, make-or-buy decisions are required on fabricated items to assure optimum performance with regard to cost, schedule, and quality.

The main manufacturing facility at AI provides $74,000 \mathrm{sq} f t$ of clear floor a rea for manufacturing and assembly operations, with an additional 27,000 sq ft devoted to office support and $13,000 \mathrm{sq} f t$ to receival and storage of raw materials.

h. Supporting Facilities

\section{(1) Analytical Chemistry}

Specialized analytical chemistry research facilities include: infrared, visible, ultraviolet, and atomic absorption spectrophotometers; mass spectrometers, polarographs; gas chromatographs; controlled-potential coulometer; inert atmosphere gloveboxes; multichannel gamma ray spectrometers with fastslow coincidence/anticoincidence capabilities; and 50-to 100-kv X-ray spectrographs. Also available for this program are standard analytical chemistry facilities for determining the properties and contents of brines, flashed steam, and non-condensibles.

\section{(2) Computer Services}

A central Corporate computer system is available for use in both technical and administrative program functions. Access to the system is provided by local terminals at AI. Additionally, the Division makes available to its engineering personnel numerous programmable desk-top computers and hand-held calculators which speed the performance of less complex, routine computations.

\section{(3) Technical Library}

Atomics International has its own technical library, has made arrangements for inter-library loans with all university libraries in the Southern California area, and has access to computerized data banks of engineering and scientific 
information. The engineering and scientific staff is therefore able to update and supplement previous experience with current literature and data.

\section{i. Regional Laboratory}

Atomics International has a unique capability in the operation of a regional resource type of laboratory. The company designed, established, and has been operating since 1966 a very large multimillion dollar test and engineering laboratory whose scope of work and charter are nearly identical to those envisaged for the ARTF, including analysis laboratories and other supporting services.

This laboratory, designated the Liquid Metal Engineering Center (LMEC), is a test laboratory operated by the Atomics International Division of Rockwell International for the Energy Research and Development Administration (ERDA).

The LMEC is located about 35 miles northwest of Los Angeles on both company - and government-owned land and employs 350 people on the staff, of whom 220 are graduate engineers.

The LMEC's primary charter is to aid ERDA in general, and the Liquid Metal Fast Breeder Reactor (LMFBR) program in particular, in developing a capability in American industry for the production of reliable and economic power from fast breeder reactor systems. 


\section{Hazen Research}

Hazen Research, Inc., was formed in 1961 to undertake contract research and development for industrial clients in the field of mineral science and technology. Starting with a nucleus of specialists in extractive metallurgy, the staff and facilities have been expanded to include all facets of the mineral industry.

Broad areas in which Hazen currently offers substantial service to clients include the following: mineral beneficiation, hydrometallurgy, flowsheet development and engineering, geology and geochemistry, computer services, mineralogy, analytical chemistry, chemical process research and development, preliminary capital and operating cost estimates, and pollution control.

Most members of Hazen's research, development, and engineering staff have had significant practical experience in operating plants containing process equipment. Company management believes that research and development programs are more productive when guided by skilled professionals who understand from experience how a potential process can be made to work in practice and produce a profit.

Hazen has been actively engaged in studies regarding mineral recovery from geothermal fluids in general, and Salton Sea geothermal brines in particular, since 1972. These efforts have been carried out under the sponsorship of the U.S. Bureau of Mines and the Southern Pacific Land Company.

These studies on minerals recovery have shown that extraction of the valuable minerals from geothermal brines may be an economically viable concept. These studies were carried out for the U.S. Department of Interior, Bureau of Mines, under Contracts Nos. SO 133084 and HO 144104, and independently, for the Southern Pacific Land Co.

Processes have been developed that may allow the recovery of several of the valuable constituents contained in the Salton Sea geothermal fluids, notably, iron, silica, manganese, zinc, lead, and lithium. A process flow design has been completed for a 10-gpm experimental plant to verify the design concepts for minerals recovery from the Salton Sea KGRA. 


\section{Phillips Petroleum Company}

Founded in 1917 as a producer of crude oil and natural gasoline, Phillips Petroleum Company has grown into a major enterprise engaged in every phase of the petroleum industry and in many petrochemical activities. With total assets of $\$ 3,606,800,000$, the Company ranks ninth in size among United States oil companies. It has 33,429 employees and 135,966 registered stockholders.

Phillips 66 petroleum products are sold coast-to-coast through 21,200 outlets. The Company is a leading U.S. producer-marketer of liquefied petroleum gases. It has refining interests in five countries.

In the chemical industries, Phillips is a leading manufacturer of nitrogen fertilizers, synthetic rubber, carbon black, polyolefin plastics, and cyclohexane which is used for manufacture of nylon. It also manufactures and sells synthetic fibers, fabricated plastic products, and packaging. It has interests in chemical manufacturing and fabricating ventures in 17 countries.

Phillips is an industry leader in producing natural gas liquids. The Company has active exploration interests in 23 countries on six continents and interests in oil and gas reserves in eight countries. Its oil and gas reserves outside the United States have increased substantially in recent years. Besides the United States, the Company produces crude oil in Venezuela, Norwegian North Sea, Nigeria, Egypt, and Iran; and natural gas in Venezuela and the United Kingdom portion of the North Sea. Significant crude oil reserves have been discovered on the Alaskan North Slope. Through its 48\% interest in Pacific Petroleums Ltd., Phillips participates in oil and gas exploration as well as in manufacture and sale of petroleum products in Canada.

The Phillips research organization has developed many new and improved products, processes, and methods. Currently, Phillips ranks second among all U.S. oil companies in number of U.S. patents held. Its process and product knowhow is licensed in 27 countries. For the sixth straight year, Phillips ranked first among oil companies in the number of U.S. patents issued during the year with 329. At year-end, 1973, Phillips owned 6,477 active U.S. patents. 
More than $25 \%$ of the Company's domestic oil production was induced through injection of natural gas, steam, water, or other fluids into underground formations to produce oil which otherwise would be left in the ground. During 1973, the Company entered into 11 new induced recovery units. At year-end, PPC owned interests in 297 induced recovery units or projects, 98 of which PPC operated. The practices of drilling, fluid handling, and injection common to induced oil recovery fields form a base for development of the reliable geothermal production and injection system necessary for successful accomplishment of the proposed program. 


\section{F. RELATED PROGRAMS IN OTHER ORGANIZATIONS}

Recognizing the stepped-up increase of activities in fields of geothermal energy over the last several years, program team members have, in addition to their contractual and in-house efforts, kept abreast of recent developments by participation and attendance at meetings, field visits, personal communications, and review of the literature. Of particular interest, will be the programs of other groups who are engaged in investigations related to the exploitation of water dominated geothermal resources. Specifically, in the area of assessment and economics of power generation, the programs being developed by the Battelle Pacific Northwest Laboratories will be used for comparative analysis. In the same area, the results of the NSF (Phases 0 and l) programs being carried out by TRW and Bechtel Power Corporation will be reviewed.

In the fields of fundamental geothermal fluid chemistry, the rmodynamics and scaling and corrosion properties, the findings of the Lawrence Laboratories (Livermore and Berkeley), U.S. Geological Survey, National Bureau of Standards, and Bureau of Mines, will be utilized in both theoretical analysis and process design considerations.

A number of investigations pertaining to novel concepts, processes, and equipment are currently being carried out under both U.S. government- and privately-funded programs. Success of any one of these programs would have a highly beneficial impact on the economic utilization of geothermal power in the Salton Sea region. Programs which warrant close examination are the Total Flow Concept (and radial flow turbine) being investigated by the Lawrence Livermore Laboratory, and the "Total Flow" type turbines such as the Helical Rotary Screw Expander being developed by the Hydrothermal Power Company and the Jet Propulsion Laboratory, and General Ener-Tech's bladeless turbine. Progress in the development of the down-well pump by the Sperry Research Center under NSF's auspices, will be seriously examined and considered for potential use. The results of the forthcoming field tests using the Van Husen down-hole heat exchanger (under development by Geo-Energy Systems, Inc.) will also be followed.

Results of investigations being conducted by the San Diego Gas and Electric Company (in association with the Ben Holt Company, Magma Power, and Magma Energy Company) in the Buttes and Heber areas of the Imperial Valley 
have been and will continue to be periodically reviewed. Relations with $S D G \& E$, for purposes of technical information exchange, have been maintained since the inception of active geothermal explorations in the Imperial Valley.

The information obtained from an NSF study currently being carried out by the Systems, Science, and Software Corporation (S-Cubed) on reservoir mechanics problems associated with geothermal power generation in the Salton Sea region will be applied in the course of the proposed program.

In summary, collaboration and coordination of related efforts underway by others will be maintained and fully exploited to insure success of the program. 


\section{G. EDUCATIONAL AND TRAINING COMPONENT}

The organization responsible for the Minerals Recovery Subprogram, Hazen Research Inc. has always made it a point of its hiring practice to employ as many college students as possible during a given project in order to afford them an opportunity to interface with industry early in their academic careers.

It is Hazen's intent to once again utilize as many college students as possible (from University of Colorado, Colorado School of Mines, and other universities in the west and elsewhere) in the implementation of the minerals recovery portion of this program.

In the environmental element of the Power Generation Subprogram, college and university students will be utilized to collect data during the year-long field activities necessary for establishment of the biological baseline. These students will be paid for their efforts, and it is anticipated that some of the information gathered will be useful to the students in preparing theses or senior projects.

Several Technology Development projects in the Power Generation Subprogram contain well-defined tasks that can be undertaken, over short time periods, as educational and training activities by students at the junior, senior, or graduate university level. Such tasks include testing and analysis of selected scale and corrosion control methods, both in the laboratory and at the site. Attempts will be made to utilize students in these areas.

The Power Generation Subprogram also contains specific, well-defined and short-term tasks within the Systems Engineering element. These tasks can provide beneficial industrial and academic interfacing at the university teaching-staff level. Tasks of the latter type include (1) compilations, analyses, and evaluations of power cycle systems that have been studied previously at other organizations and at universities: (2) analyses of complex heat transfer problems; and (3) special cycle analyses. Additional opportunities will be available under the ARTF program; these include specifications for ARTF facilities and participation in ARTF functions. AI routinely uses university personnel at the professor level during the summer months. 
H. VITAE AND BIBLIOGRA PHIES

Resumes for key program personnel are provided in Appendix D. 


\section{CURRENT SUPPORT}

The current activities on which the project team members are working are summarized below:

\section{J. L. Rasband - Principal Investigator}

$30 \%$ - Supervision of individuals involved in geothermal energy projects $20 \%$ - Project management of fuel call research and development project

$15 \%$ - Supervision of individuals involved in energy production from solid wastes

$15 \%$ - Supervision of individuals involved in power plant cooling system research

$20 \%$ - Overhead activities.

All of Mr. Rasband's activities are funded internally by SCE. Assuming the proposed program is funded, his commitments will be adjusted to allow him to spend $50 \%$ of his time managing the program.

2. W. C. Racine - Project Manager, Power Generation

$50 \%$ - Project management of pilot geothermal generating station

$20 \%$ - Project management for alternate cooling systems research activities

$10 \%$ - Project management for miscellaneous nuclear power research and development activities

$20 \%$ - Overhead activities.

All of Mr. Racine's activities are funded internally by SCE. Upon funding of this program, his commitments will be adjusted to allow him to spend $80 \%$ of his time on the program.

3. I. R. Straughan-Environmental Coordinator

$30 \%$ - Management of contract studies of saline water use in agriculture $30 \%$ - Management of contract studies on effects of trace element enrichment on agricultural and natural ecosystems 
$30 \%$ - Development of environmental sensitivity indices and predictive environmental impact models

$10 \%$ - Supervision of environmental impact studies of $R \& D$ facilities.

All of Dr. Straugham's activities are funded internally by SCE. Under funding of this program, his commitments would be adjusted to allow him to spend $25 \%$ of his time supervising the environmental assessment studies of this program.

4. B. W. Berthelot - Project Manager, Reservoir Production

Full time involvement with geothermal operations for the western United States. These activities are wholly funded by Phillips. Assuming successful funding of this proposal, Mr. Berthelot's commitments will be adjusted to allow him to spend approximately $40 \%$ of his time on the program.

5. C. E. Berthold - Project Manager, Mineral Recovery

$20 \%$ - Instrumentation design and hardware procurement for preheater furnaces

$10 \%$ - High temperature furnace design

$20 \%$ - Investigation of mineral recovery from geothermal brines

$20 \%$ - Air and water pollution studies

$20 \%$ - Mineral boneficiation studies

$10 \%$ - Overhead activities.

Approximately $90 \%$ of $\mathrm{Mr}$. Berthold's salary is supported by outside funding. Assuming successful funding of this proposal, Mr. Berthold's work will be adjusted to allow him to spend $50 \%$ of his time on the program.

6. S. Sudar - Project Manager, Area Resource Test Facility

$40 \%$ - Project management of advanced storage battery development; funded by AI, Electric Power Research Institute, and Argonne National Laboratory

$30 \%$ - Project management of geothermal energy programs; funded by SCE and AI 
$10 \%$ - Project management of an electroplating wastewater purification system; funded by EPA, Metal Finishers' Foundation, and AI

$10 \%$ - Project management of company-funded solar energy development programs

$10 \%$ - Overhead functions such as proposal preparation for advanced energy projects.

Assuming successful funding of the proposed program, Mr. Sudar will spend $50 \%$ of his time working on the program.

7. T.H. Springer - Project Engineer, ARTF

$10 \%$ - Project management of advanced storage battery development

10\% - Project management of geothermal energy programs; funded by SCE and AI

$30 \%$ - Project management of solar energy development programs and studies of solar energy systems; funded by AI and the National

Science Foundation

$30 \%$ - Overhead functions such as proposal preparation for advanced energy projects; AI funded

$20 \%$ - Fast breeder reactor physics studies; funded by USAEC.

8. J. Van Osdol

$50 \%$ - Coal gasification program; funded by Office of Coal Research

$50 \%$ - Systems analysis of $\mathrm{ZrH}$ reactors; funded by USAEC. 


\section{J. PATENT INFORMATION}

SCE, AI, Hazen, and PPC have conducted extensive work in their respective areas of expertise related to the proposed program. Because of this past work, it is suggested that the following "Rights in Inventions" clause be included in the contract to be executed between SCE and ERDA:

\section{RIGHTS IN INVENTIONS}

In view of the substantial work performed by the contractor in the study of geothermal brines and in view of the technical competence of contractor in the field of power generation and distribution in which contractor has acquired as established nongovernmental commercial position, contractor requests that at the time of award of this contract, contractor be allowed to retain or obtain principal rights in any invention or possible future inventions made under this contract, subject to the Government of the United States retaining a nonexclusive, nontransferable, paid-up license to make, use, and sell the invention throughout the world by or on behalf of the Government of the United States. 
K. DEFINITION OF TERMS

AI

AR TF

Hazen

Mono

Participants

PPC

SCE

SPL
- Atomics International Division of North American Rockwell

- Area Resource Test Facility

- Hazen Research, Inc.

- Mono Power Company, a subsidiary of SCE

- Signatories of the Geothermal Energy and Materials Research and Development Agreement (i.e., SCE, PPC, and SPL)

- Phillips Petroleum Company

- Southern California Edison Company

- Southern Pacific Land Company 


\section{APPLICATIONS TO OTHER POTENTIAL SPONSORS}

Hazen Research has provided U.S. Bureau of Mines personnel with an engineering study and cost estimate for construction of an experimental mineral recovery plant. This plant is similar to the mineral recovery plant proposed in this program.

Hazen and the Principal Investigator will pursue the possibility of obtaining funding from the Bureau of Mines for a portion of the Mineral Recovery Subprogram contained in this proposal. Should the Bureau decide to contribute funding, the amount contributed will be deducted from the ERDA funding amounts. 


\section{BUDGET}

Total Phase 1 program expenditures are estimated to be $\$ 5.4$ million. The program budget is broken down by subprograms and tasks below.

POWER GENERATION SUBPROGRAM

Task A - Technology Development

$\$ 1,767,500$

Task B - Environment

281,500

Task C - Systems Engineering

769,700

Subtotal

$\$ 2,818,700$

MINERAL RECOVERY SUBPROGRAM

Task A - Selection of Mineral Recovery Frocess

$\$ 10,000$

Task B - Recommendation of Brine Clean-up Methods

10,000

Task C - Design and Engineering of Facilities

72,000

Task D - Construction of Facilities

540,000

Task E - Operation of Experimental Facilities

310,000

Task F - Analysis of Facilities

55,000

Task G - Pilot Plant Preliminary Design 200,000

Subtotal

$\$ 1,197,000$

RESERVOIR PRODUCTION SUBPROGRAM

Task A - Brine Production and Injection

$\$ 748,000$

Task B - Reservoir Assessment 60,000

Subtotal

$\$ 808,000$

AREA RESOURCE TEST FACILITY SUBPROGRAM

Task A - Requirements Survey

$\$ 27,200$

Task B - Preliminary Design and Cost Estimate 174,200 Subtotal

$\$ 201,400$ 
UTILIZATION OF RESULTS

Advisory Committee Meetings

$\$ 33,100$

Reports

15,200

Seminars + Proceedings

10,000

Technical Papers

6,100

Subtotal

$\$ 64,400$

PROGRAM MANAGEMENT

Site Preparation

$\$ \quad 141,000$

Commercialization Model

50,000

Management Activities

137,000

Subtotal

$\$ 328,000$

TOTAL, PHASE 1

$\$ 5,417,500$

Assuming Phase 1 can be initiated on July 1, 1975, the following table shows estimated expenditures for Fiscal Years 1976 and 1977 by subprogram (rounded to the nearest $\$ 100,000$ ).

\begin{tabular}{l|c|c}
\hline \multirow{2}{*}{ Subprogram } & \multicolumn{2}{|c}{ ERDA Costs } \\
\cline { 2 - 3 } & FY 1976 & FY 1977 \\
\hline Power Generation & $\$ 1.5$ million & \$1.3 million \\
Mineral Recovery & 0.7 & 0.5 \\
Reservoir Production & 0.5 & 0.3 \\
Area Resource Test Facility & $0.2^{*}$ & TBD \\
Program Management & 0.2 & 0.2 \\
Subtotal & $\$ 3.1$ million & $\$ 2.3$ million \\
TOTAL, PHASE 1 & & $\$ 5.4$ million \\
\hline
\end{tabular}

* Covers design and facility cost estimate. Costs of construction and operation are additional.

†Program Management includes the costs for Utilization of Results $(\$ 64,400)$. 
In comparison to the $\$ 5.4$ million cost estimate for Phase 1, SCE, PPC, and SPL will have spent over $\$ 2.2$ million on Phase 0 activities prior to initiation of Phase 1. These expenditures are summarized below.

\section{Participants' Phase 0 Costs}

1. Geothermal Leases $\$ 750,000$

2. Research and Development

a. Common Funds

744,000

b. SCE

275,000

c. SPL

210,000

d. PPC

230,000

TOTAL, PHASE 0

$\$ 2,209,000$

Phase 0 activities resulted in an identification of the major $R \& D$ requirements for the Salton Sea geothermal area and will provide fundamental data and a basic brine handling system that will allow Phase 1 tests to proceed quickly, smoothly, and logically.

The Participants also anticipate significant expenditures in support of Phase 1 ERDA-sponsored activities contained in this proposal. The anticipated costs are summarized below.

\section{Participants' Costs Supportive of Phase 1 Program}

1. Geothermal Leases

$\$ 250,000$

2. Research and Development
a. $\mathrm{SCE}$
210,000
b. SPL
24,000
c. PPC
160,000
TOTAL PHASE 1
$\$ 644,000$ 


\section{REFERENCES}

1. V.A. Stevovich, "Soviet Geothermal Electric Power Enginering Report 2," Report to AFOSR, Informatics, Inc., Dec. 1972, p 18-20

2. H.C. Helgeson, Am. Jour.Sci., 266, 129-166 (1968)

3. H. D. Holland, "Gangue Minerals in Hydrothermal Deposits," in Geochemistry of Hydrothermal Ore Deposits, ed. by N. L. Barnes (Holt, Rinehart \& Winston, Inc., New York City, 1967) pp 388-393

4. Private Communication, Dr. Harry K. Bishop, SDGE

5. S. Hermannsson and W. Wiederholt, Werkstoffe Korrosion, 13, 65, 1962

6. Private Communication, Dr. Glenn A. Marsh, Union Oil Co. of California

7. W.H.Friske, "Hot Salt Stress Corrosion of Inconel Alloy 718," Report No.TR-001-138-001, November 1,1972, Atomics International, A Division of North American Rockwell Corporation, Canoga Park, California

8. H.W. Pickering, et al., Trans. ASM, 53, 793-803 (1961)

9. F. Mansfeld, et al., "The High Temperature Behavior of Super-alloys Exposed to Sodium Chloride. II. Corrosion, "North American Rockwell Science Center, Preprint No.SC-PP-72-17, February 1972

10. Saline Water Conversion Report 1970-1971, Office of Saline Water, U.S. Department of the Interior, Washington, D.C.

11. W. G. Cochran, Sampling Techniques, (John Wiley \& Sons, New York 1963) 


\section{APPENDIX A \\ AN ASSESSMENT OF THE ENERGY CAPACITY \\ OF THE SALTON SEA KGRA}

A - I 

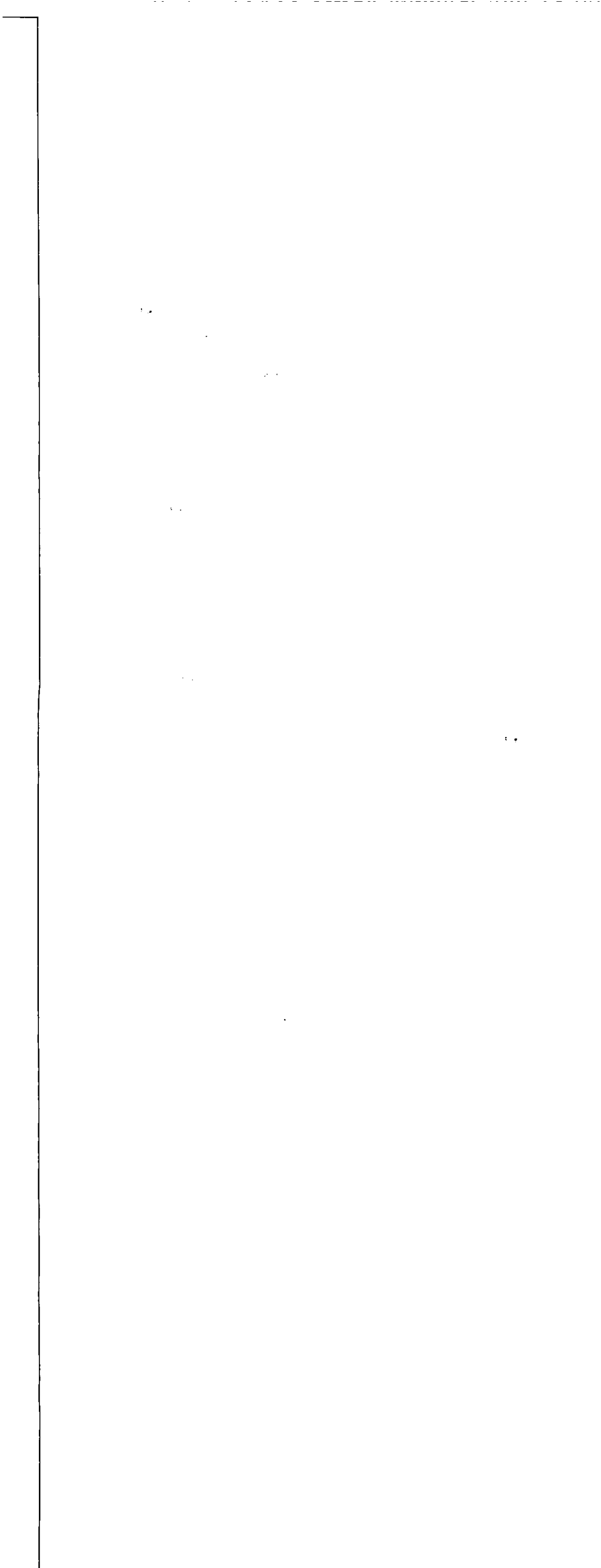

. 
The total energy content of the Salton Sea Geothermal Field is not known accurately. The values for this parameter are found to vary by a factor of 10 to 30 from one estimate to another. All estimates appear to indicate, however, that the total energy content is high and that significantly large amounts of electrical power can be produced from the field for many decades. H. C. Helgeson states in References A-1 that, with regard to the Salton Sea Geothermal Field, "no change in enthalpy, temperature, or brine composition has occurred during sustained (as long as 18 months) production tests of the various wells, and no evidence of well interference has been detected. Conservative calculations indicate the presence of more than $5 \times 10^{10} \mathrm{ft}^{3}$ of concentrated brine and $10^{15}$ kilocalories of heat (contained in the brine) in the reservoir. With a casing on the order of ten inches in diameter, a single well in the Salton Sea geothermal area is capable of producing more than $350,000 \mathrm{ft}^{3}$ of formation fluid per day. In the process, approximately 2700 short tons of dissolved solids and more than $2 \times 10^{9}$ kilocalories of heat would be delivered daily to the surface. " This heat delivery corresponds to approximately $100 \mathrm{MWt}$ or about $30 \mathrm{MWe}$ from a single well. The $10^{15}$ kilocalorie total heat content translates to approximately $1.3 \times 10^{3}$ MWcen (Megawatt-century) thermal or approximately $4.3 \times 10^{2}$ MWcen electric, assuming that a high conversion efficiency of about $30 \%$ can ultimately be achieved.

In an independent assessment, Marshall Reed (A-2) states that the volume of water contained in the Obsidian Buttes area (Salton Sea Geothermal Field) is approximately $7 \mathrm{~km}^{3}$ and that this volume is probably only one-half the total. Using a value of $14 \mathrm{~km}^{3}$ and such simplifying assumptions that the brine density is $1 \mathrm{gm} / \mathrm{cm}^{3}$ and the enthalpy is $230 \mathrm{cal} / \mathrm{gm}$, one can derive as estimate of $3.4 \times 10^{15}$ kilocalories for the total energy content. This heat content would correspond to $4.5 \times 10^{3} \mathrm{MWcen}$ thermal or approximately $1.5 \times 10^{3} \mathrm{MWcen}$ electric.

A third estimate of the heat content in the Salton Sea Geothermal Field can be obtained on the basis of reservoir models made by L.C. Dutcher, et al., in Reference $\mathrm{A}-3$. This estimate, which utilizes an approximation by White ${ }^{(\mathrm{A}-4)}$ of $50 \mathrm{~km}^{2}$ for the area covered by the anomaly, yields a value of $5 \mathrm{~km}^{3}$ for the volume occupied by the brine. If, again, the above assumptions regarding density and enthalpy are made, one obtained an estimate of $1.6 \times 10^{3}$ MWcen thermal $\left(5.3 \times 10^{2}\right.$ MWcen electric). 


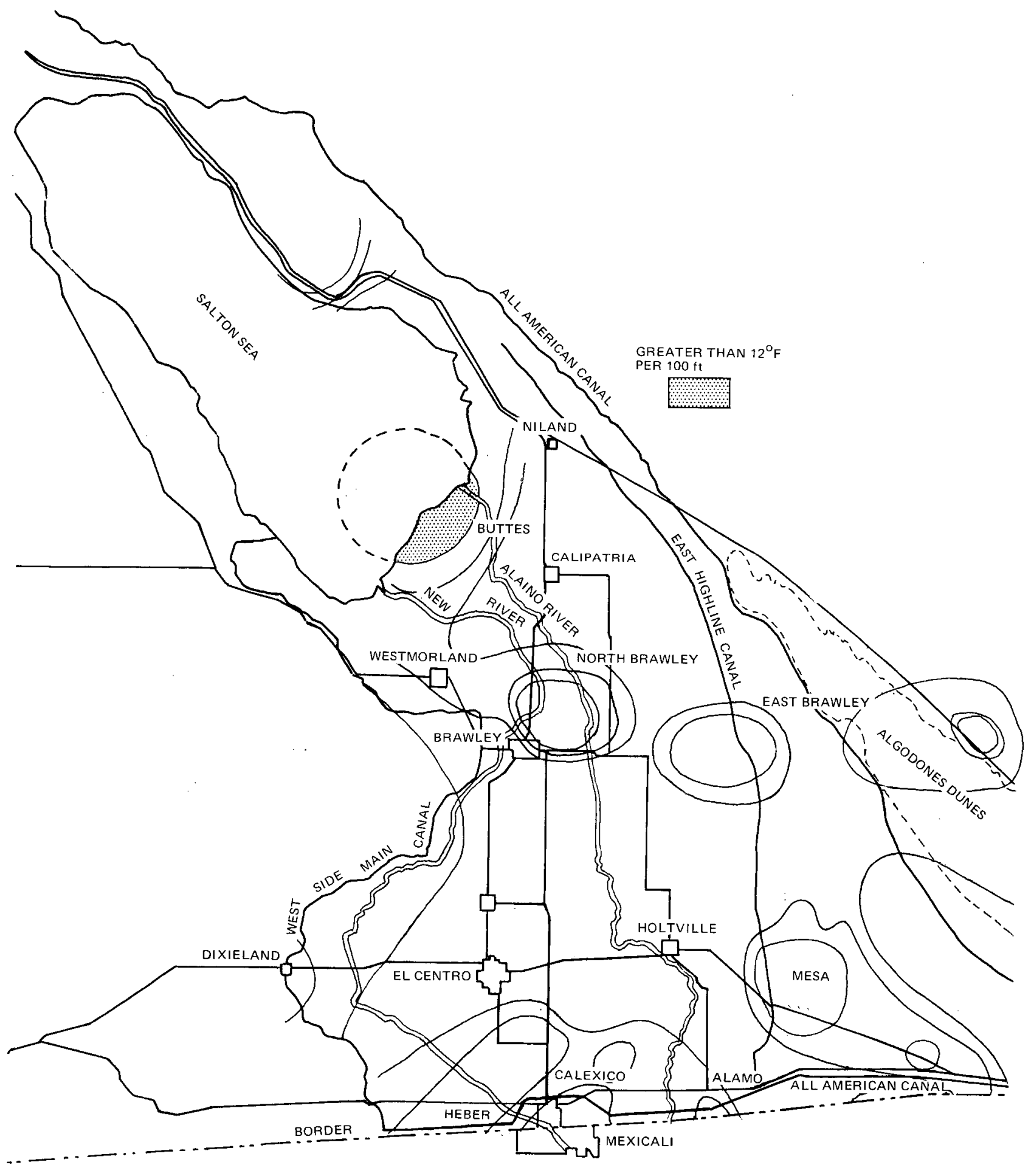

Figure A-1. Estimated Extent of the Salton Sea Geothermal Field Adapted from Reference A-5 
A very simplistic and perhaps upper-limit-type of estimate has also been made by Atomics International, using temperature gradient and depth-tobasement data prepared by $\operatorname{Rex} \mathrm{x}^{(\mathrm{A}-5)}$ and using a porosity value of $20 \%$ as estimated by Reed. $(\mathrm{A}-2)$ If one assumes that the zone in the Salton Sea Geothermal Field estimated to have a temperature gradient greater than $12^{\circ} \mathrm{F} / 100 \mathrm{ft}$ is a segment of a circle whose center lies within the body of water of the Salton Sea, then an area of about $130 \mathrm{~km}^{2}$ (radius $=4 \mathrm{mi}$ ) for the water bearing rock is obtained in the manner shown in Figure A-I which is taken from Reference A-5. The dashed circle has been added to the Figure in order to indicate the extent of the extrapolation involved. However, this area corresponds rather closely in size (but not so well in location) with the very approximate size of the Salton Sea Geothermal Anomaly given by Dutcher in Reference A-3. The vertical height of the zone that is assumed to contain material at a temperature greater than $180^{\circ} \mathrm{C}$ is estimated to extend from $900 \mathrm{~m}$ to $5000 \mathrm{~m}$ below the surface. The former value is obtained by determining the depth required, on the basis of a $12^{\circ} \mathrm{F} / 100 \mathrm{ft}$ gradient, to achieve a temperature of at least $180^{\circ} \mathrm{C}$. The latter value is about the median value given by $\operatorname{Rex}^{(\mathrm{A}-5)}$ for the depth to the basement. On the basis of these parameters, a total volume of about $550 \mathrm{~km}^{3}$ is obtained, a volume that, if assumed to have $20 \%$ porosity would contain about $110 \mathrm{~km}^{3}$ of brine. With the assumptions made above as to brine density and enthalpy, an energy storage value of $3.3 \times 10^{4}$ MWcen thermal ( $1.1 \times 10^{4}$ MWcen electric) can be derived.

It is seen therefore that the total energy content in the Salton Sea Geothermal Field is considerable and could, on the basis of higher efficiency power cycles and optimistic resource assumptions, be as high as 30,000 MWcen, although current information would place the value more probably in the neighborhood of 2,000 to 3,000 MWcen electric if one takes into account the heat content of the rock as well as the heat content in the brine. 
A-1. H. C. Helgeson, "Geologic and Thermodynamic Characteristics of the Salton Sea Geothermal System, "American Journal of Science, Vol.266, March 1968 , pp $129-166$

A-2. Marshall Reed, "Imperial Valley, "Geothermal World Directory, 1973, Katherine F. Meadows. Editor and Publisher, August 1973, Glendora, CA, pp $141-153$

A-3. L.C. Dutcher, et al., "Preliminary Appraisal of Ground Water in Storage With Reference to Geothermal Resources in the Imperial Valley Area, CA, "Geological Survey Circular 649, 1972, p 22

A-4. D. L. White, "Environments of Generation of Some Base-Metal Ore Deposits," Econ. Geology, V.63, No.4, pp 301-335

A-5. R.W. Rex, "Investigation of Geothermal Resources in the Imperial Valley and Their Potential Value for Desalination of Water and Electricity Production, "The Institute of Geophysics and Planetary Physics, University of California, Riverside, June 1970. 
APPENDIX B

A COMPARATIVE EVALUATION OF GEOTHERMAL POWER CONCEPTS

B - 1 


\section{APPENDIX B}

A COMPARATIVE EVALUATION OF GEOTHERMAL POWER CONCEPTS

\section{A. Introduction}

As part of the participants' Phase 0 Program, a general technical evaluation has been made for a large number of possible power cycles. Analysis of power production capabilities have been included for six basic cycles which incorporate direct steam turbine operations or heat exchange between flashed steam and a secondary fluid (including pure water). The remaining cycles are evaluated on technical merits alone because either the power production efficiency is known to be similar to one of the six analyzed (and less important than technical problems) or insufficient data are available to permit a quantitative performance calculation to be made.

The performance analyses considered both single and multistage flashing of the brine. Uniform well head and heat sink temperatures were assumed for all cycles in order that the comparisons would be independent of other influences. The well-head conditions used in the cycle studies are shown in Table $B-1$.

\section{TABLE B - 1}

\section{WELL-HEAD CONDITIONS USED IN THE CYCLE STUDIES}

$\begin{array}{ll}\text { Steam Flow } & 494,000 \mathrm{lb} / \mathrm{hr} \\ \text { Brine Flow } & 2,326,000 \mathrm{lb} / \mathrm{hr} \\ \text { Brine Temperature } & 426^{\circ} \mathrm{F} \\ \text { Brine Pressure } & 265 \mathrm{psia} \\ \text { Salt Concentration } & 270,000 \mathrm{ppm}(327,000 \text { in brine fraction) }\end{array}$

Condensing temperatures of $101^{\circ} \mathrm{F}$ for direct contact condensers, $115^{\circ} \mathrm{F}$ for surface condensers with wet towers, and $141^{\circ} \mathrm{F}$ for direct condensers with dry towers were selected as being compatible with Imperial Valley weather conditions and probable cooling tower designs. To simplify the comparisons it was assumed that the cooling tower water would be available at $90^{\circ} \mathrm{F}$ and returned to the tower at $101^{\circ} \mathrm{F}$ for all cases. Actually a higher water temperature would be feasible for the isobutane case because 
of the high temperature at which isobutane enters the condenser; however, this refinement would have little effect on the overall conclusions.

Thermodynamic properties of the brine solution were taken

from the experimental data obtained by Denver Research Institute. The enthalpy values used in this analysis are shown in Figure 1 . In several of the cycles, the maximum salt concentration - in the brine from the last flash evaporator - exceeds the solubility boundary shown in Figure 1. This will cause the precipitation of "soluble" salts; however, it is believed that the resulting slurry can be handled in conventional equipment, and condensate can be added to the brine to redissolve the salts, if necessary, before reinjection. A boiling point rise of $20^{\circ} \mathrm{F}$ was assumed for all salt solutions to simplify the analysis; although the available data indicate that this value varies somewhat with both pressure and concentration in the ranges of interest.

The following cycles were considered in analysis:

1. Direct steam
a. single flash stage
b. two flash stages
c. three flash stages

2. Steam-to-steam cycle
a. single flash stage
b. two flash stages
c. three flash stages

3. Steam-to-isobutane cycle
a. two flash stages (600 psia top pressure)
b. three flash stages (600 psia top pressure)
c. three flash stages (1050 psia top pressure)

4. Steam-to-N-butane cycle, single flash stage

5. Steam-to-freon 114 cycle, single flash stage

6. Steam-to-ammonia cycle, single flash stage 
Process flow diagrams and the arrangement of the process equipment assumed for the studies are shown in Figures 2 through 11. Steam separation from the brine is accomplished in flash evaporators which are arranged in 1,2 , or 3 stages. In the direct steam cycle, this steam is taken through purifiers associated with each flash evaporator vessel.

The multi-stage flash cycles require multi-pressure admission steam turbines. Based on discussions with turbine manufacturers, no difficulties are to be expected in the manufacture of multi-pressure admission turbines for the steam conditions selected here. In the steam process flow systems shown in the figures, each one of the flash evaporators supplies the total feedwater heating and steam generation requirements for one turbine admission stage.

In the thermodynamic analyses, a stage efficiency of $85 \%$ was assumed for the high pressure stages. The degrading effect of moisture on turbine performance was taken partially into account by assuming a loss of $1 \%$ stage efficiency for each per cent moisture in the stage. An electrical generator efficiency of $97 \%$ and a mechanical drive efficiency of $98 \%$ was assumed. Multi-staging of binary fluid turbines is not required because of the relatively low ratio of latent heat of vaporization to sensible heat of the fluid.

The results of the cycle performance studies are summarized in Tables B -2 and $B-3$.

The direct steam cycle shows the highest performance of all the cases considered. Somewhat surprisingly, the steam-to-steam cycle shows a performance capability approximately equal to that of the is obutane cycle. If the difference in pump work between these two systems is considered, as shown in the last column of Table B -3, even the high temperature and pressure isobutane cycle $\left(380^{\circ} \mathrm{F}, 1050 \mathrm{psia}\right)$ shows little or no performance advantage over the steam-to-steam cycle. Taking into account the higher capital costs due to higher pressure pipes and heat exchanger tubes, the larger pump requirements, the considerably higher mass flow rates (which entails larger pumps and pipes), the substantially larger heat transfer 
TABLE B -2

SUMMARY OF CYCLE STUDIES

(Power Production from 2, 820, 000 lb/hr Well Flow)

\section{Cycle}

Direct Steam, Wet Tower

Direct Steam, Dry Tower

Steam-to-Water, Wet Tower

Steam-to-Water, Dry Tower

Steam-to-Isobutane, 600 psi system

Steam-to-Isobutane, 1050 psia system

Steam-to-N butane

Steam-to-Freon 114

Steam-to-Ammonia

Total Flow Concept, 90\% Efficiency $85 \%$ Efficiency
Gross Generator Output, $\mathrm{Mw}$ 1 Stage 2 Stage 3 Stage

42. 9

49. 0

54. 7

34.6

41. 0

45.8

35.0

42. 9

47. 0

30.2

37. 4

41.3

38. 0

42. 0

30.6

30.8

27. 0

62.0

57. 0
49. 0
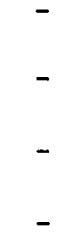
TABLE B -3

COMPARISON OF POWER CYCLE REQUIREMENTS

(Basis $100 \mathrm{Mw}$ Gross Electrical Output)

Cycle

Requirements

$\frac{\text { Well Production Cooling Water Power Cycle }}{10^{6} \mathrm{lb} / \mathrm{hr}}$
\[ \frac{\text { Circ }}{10^{6} \mathrm{lb} / \mathrm{hr}} \frac{\text { Makeup }}{10^{6} \mathrm{lb} /} \frac{\text { Fluid Pumping }}{\mathrm{Mw}} \]

Direct Steam, Wet Tower

$\begin{array}{llll}1 \text { stage } & 6.6 & 120.0 & 1.6 \\ 2 \text { stage } & 5.8 & 123.3 & 1.7 \\ 3 \text { stage } & 5.2 & 111.1 & 1.5\end{array}$

Direct Steam, Dry Tower
1 stage
8.2
2 stage
6.9
3 stage
6.2

Steam to Water, Wet Tower

$\begin{array}{lllll}1 \text { stage } & 8.1 & 150.9 & 2.1 & 0.15 \\ 2 \text { stage } & 6.6 & 139.9 & 1.9 & 0.25 \\ 3 \text { stage } & 6.0 & 130.4 & 1.8 & 0.30\end{array}$

Steam to Water, Dry Tower

$\begin{array}{lllll}\text { l stage } & 9.3 & - & - & 0.17 \\ 2 \text { stage } & 7.5 & - & - & 0.29 \\ 3 \text { stage } & 6.8 & - & - & 0.34\end{array}$

Steam to is obutane

$\begin{array}{lrrrr}2 \text { stage - 600 psia } & 7.4 & 162.1 & 2.3 & 13.32 \\ 3 \text { stage - 600 psia } & 6.7 & 163.1 & 2.3 & 13.38 \\ 3 \text { stage - } 1050 \text { psia } & 5.8 & 125.0 & 1.8 & 21.27 \\ \text { to N-butane } & 9.2 & 190.5 & 2.7 & 7.78 \\ \text { to Freon } 114 & 9.2 & 189.3 & 2.6 & 19.45 \\ \text { to Ammonia } & 10.3 & 218.3 & 3.1 & 13.85\end{array}$


surface requirements due to the poor thermal properties of isobutane, as shown in Table B-4, and the unavailability of a proven turbine design in the size range required for geothermal plants, it becomes difficult to consider selecting the isobutane system in preference to a proven steamto-steam, or direct steam cycle. However, a developed isobutane turbine should be appreciably lower in cost than a low pressure steam turbine operating over the same temperature range because of the much smaller volume of isobutane vapor involved. As a result, a more detailed cost analysis is warranted. All of the other binary cycles show a relatively poor performance capability and do not appear to warrant further consideration.

TABLE B -4

RELATIVE HEAT TRANSFER COEFFICIENT

\begin{tabular}{|c|c|c|c|}
\hline Fluid & Liquid & $\begin{array}{c}\text { Non-Condensing } \\
\text { Vapor } \\
\end{array}$ & $\begin{array}{c}\text { Condensing } \\
\text { Vapor } \\
\end{array}$ \\
\hline $\mathrm{H}_{2} \mathrm{O}$ & 1.0 & 1.0 & 1.0 \\
\hline Freon & .16 & .44 & .29 \\
\hline Ammonia & 1.26 & 1.31 & 1.12 \\
\hline Butane & .41 & .42 & .38 \\
\hline Isobutane & .45 & .45 & .41 \\
\hline
\end{tabular}

Theoretically, the total flow concept has a high performance capability because it involves continuous rather than stepwise flashing of the brine and expansion of the flashed steam. In view of its design simplicity (i.e., no flash evaporators or heat exchangers), it also could be a very low capital cost system. However, the ability of the turbine to operate with a high-velocity, two-phase brine solution can only be established by an extensive development program. 


\section{B. Direct Steam Cycles}

In these cycles the steam turbines operate on steam flashed directly from the brine. Highly efficient separators and steam purifiers are required since even a minor carry-over of high salinity brine accelerates corrosion and leads to deposition of solids on the turbine blades. Non-condensible gases present in the flashed steam also contribute to corrosion and result in the requirement for non-condensible gas removal from the steam condenser. Some minor modifications in turbine design, such as elimination of crevices and labyrinth seals between stages, can be made to ease some of the problems from impurities in the steam.

Saturated steam turbines have to deal with increasing moisture content in the expanding steam. This problem is reduced somewhat with multi-admission turbines because the steam introduced into the lower pressure stages does not expand to as high a moisture content. Moisture separator stages can be considered if necessary to keep wetness within manageable limits. Another approach which should be considered for multi-admission turbines is the superheating of low pressure steam using a portion of the higher pressure steam for the purpose. Moisture content is not a problem with isobutane and freon cycles since the vapor does not expand into the wet region in the turbine.

Special designs must be developed for multiple inlet turbines when two or three stage flashing is applied. Discussions with turbine designers indicate this is not a problem. They feel that as many as four inlet stages are feasible. A potential limitation is the large inlet ducts required for the lowest pressure stage. In some cases, separate turbines for each pressure may be the best compromise. 


\section{Indirect Steam (Steam-to-Water) Cycles}

In the se cycles steam flashed from the brine in one or more flash stages is condensed in tubular heat exchangers in which pure water is heated and boiled to produce pure steam. This permits the use of "conventional" low pressure steam turbines operating on pure steam. In order to maintain the purity of the secondary steam circuit, direct contact condensers using cooling tower water are not practical and it is necessary to provide surface condensers to separate the recycled pure water and cooling water streams. The two sets of heat exchangers (steam generators and condensers) decrease the temperature range of the steam-to-water cycles compared to direct steam cycles and thereby cause a decrease in efficiency.

Although the impure flashed steam is kept out of the turbine, it must be handled in a large heat exchanger. This heat exchanger must be resistant to corrosion by $\mathrm{H}_{2} \mathrm{~S}, \mathrm{CO}_{2}$, ammonia, boric acid, and entrained brine. It must also be designed for ease of cleaning because of the possibility of fouling on the flashed steam side.

A further source of inefficiency in indirect cycles is the need to pump the feedwater from the condenser to the steam generator. Such pumps are not required in direct steam cycles.

\section{Steam-to-Secondary Fluid Cycles}

These cycles are very similar to the steam-to-water cycles described above and many of the same considerations apply. The difference is that a second fluid is selected which has thermodynamic properties particularly well suited to the temperature interval available. Specific criteria are a reasonable pressure at the top temperature (e.g., less than 2000 psi) and a vapor pressure slightly over atmospheric at the temperature of condensation. Other requirements are a low cost and high level of stability. After reviewing a number of candidates, four were selected for detailed analysis - isobutane, N-butane, Freon 114, and ammonia.

Steam generators and heat exchangers between the flashed steam and working fluid must be designed to accommodate cleaning. The drop in 
temperature of any brine droplets carried by the steam can lead to precipitation of chemicals and scaling of the brine-side heat transfer surface. This problem is compounded in the isobutane and freon systems because of their substantially larger heat transfer areas relative to the all-steam system.

Turbines for isobutane and the other secondary fluids in the size required for geothermal power are beyond the state-of-the-art as developed to date. Designs can be extrapolated from existing smaller units, but the lack of a successful long-time operating history for units of this size introduces a degree of uncertainty in the application of such units to geothermal power.

We have discussed expansion turbines for isobutane and other secondary fluids with a major manufacturer. They claim that there is no basic size limitation. They have built hundreds of units. Most are in the 1000 to $2000 \mathrm{HP}$ range. They have six frame sizes. The largest frame size is $12,000 \mathrm{HP}(8-9 \mathrm{Mw})$. One more step will take them to a size equivalent to a $50 \mathrm{Mw}$ generator. There is no problem doing this, there just has not been a demand in the past. The bigger turbines will turn at lower speeds and thus actually be easier to design and operate. They favor the $50 \mathrm{Mw}$ as the initial geothermal power unit size. It would turn at 3600 RPM and the refore match available 2 pole generators.

Efficiencies are as good or better than steam turbines - 82 to $85 \%$. Expansion ratios of $1: 2$ or $1: 2-1 / 2$ a re quite good, $1: 3$ is acceptable if a few per cent efficiency loss can be tolerated. For greater expansions 2 or 3 stages (usually separate machines) can be used.

\section{E. Total Flow Concepts}

In the total flow concept the entire output of a geothermal well is expanded through a prime mover which is used to drive a generator. Several prime mover concepts have been proposed including pelton wheels, radial inflow turbines, bladeless turbines, helical screw expanders, and rotoroscillating vane machines. 
It appears that the adaptation of turbine concepts already developed in large sizes for hydraulic power generation would require a less extensive development effort than the development of radically new concepts.

Although hydraulic impulse turbines for the total flow concept are within the present state-of-the-art with respect to size, a substantial development effort will be required to adapt these to the erosive/corrosive/ scaling environment of high velocity, two-phase hot brine solutions. Multistaging of pelton wheels or radial inflow turbines introduces unique hydrodynamic design problems which are compounded in two-phase flow systems. Lack of an analytical model for two-phase brine flow in the turbine buckets and nozzles compounds the experimental problems and increases the development time and development costs.

The development program would require a supporting experimental study of the dynamic corrosion of materials under flashing flow before a turbine design can be attempted. Also, the dynamic properties of flashing brine solutions are not known, and probably would be required before the nozzle and turbine designs could be optimized. Preliminary studies of exit nozzle velocities and peripheral wheel speeds indicate a need for at least a two-stage hydraulic turbine. This could present a difficult design problem since bucket and radial inflow impulse hydraulic turbines are inherently single-stage machines. Nevertheless, because of the potential for achieving high performance at low cost, the total flow energy recovery device deserves further consideration. It should be recognized that this approach is much longer range and less promising than either the direct steam or steam-to-secondary fluid cycles and work on a total flow concept should not replace the development work on these more conventional systems.

\section{F. Brine-to-Secondary Fluid Cycles}

The isobutane turbine plus downhole pump concept permits total well flow of the brine to an isobutane heat transfer system. It is a simple flow arrangement since steam separators are not required. High cycle 
efficiency is possible and scale deposition in the well is minimized. A once-through heat exchanger can be considered.

However, severe corrosion and scaling problems may occur in the tubular heat exchangers. Certainly silica deposition will be a problem and the downhole pump and isobutane turbine need to be developed.

The hybrid isobutane turbine with a flashed steam plus brine heat transfer system does not need a downhole pump. However, it retains the deposition and corrosion problems associated with tubular brine heat exchangers. Is obutane turbine development is also required.

\section{G. Downhole Heat Exchanger}

Some of the performance characteristics of the downhole heat exchanger were briefly scrutinized. The concentric tube arrangement in which injection water is carried down the well hole through a central pipe and hot steam is brought up in the annular space between the pipe and the well casing was selected for study. In this concept, it is desirable to minimize thermal refluxing between the injection water and the process steam which lowers the availability of the steam at the well head. The effectiveness of the concept depends on maintaining refluxing to a low level.

A number of typical designs were evaluated using injection pipe diameters of 4,6 and 8 inches, with and without thermal insulation. Injection pipe lengths of 4000 and $6000 \mathrm{ft}$ were considered to establish the effect of pipe length on refluxing. The temperature of the well bottom was assumed to be $600^{\circ} \mathrm{F}$, and the injection water was assumed to enter the well at a temperature of $100^{\circ} \mathrm{F}$. A flow rate of $300,000 \mathrm{lb} / \mathrm{hr}$ was assumed. The results of the analyses are shown in Table B -5 .

TABLE B -5

THERMAL REFLUXING IN A DOWNHOLE HEAT EXCHANGER

Pipe Diameter, in.
Pipe

$$
\text { Length, ft. }
$$

Exit Steam

Temp, ${ }^{\circ} \mathrm{F}$
4

6
4000

6000

4000 
TABLE B -5 (Cont'd)

\begin{tabular}{|c|c|c|}
\hline Pipe Diameter, in. & $\begin{array}{c}\text { Pipe } \\
\text { Length, ft. }\end{array}$ & $\begin{array}{l}\text { Exit Steam } \\
\text { Temp, }{ }^{\circ} \mathrm{F}\end{array}$ \\
\hline Uninsulated & & 129 \\
\hline $\begin{array}{l}1 / 2^{11} \text { Insulation }(\mathrm{K}=0.08 \\
\mathrm{Btu} / \mathrm{ft}-\mathrm{hr}-{ }^{\circ} \mathrm{F}\end{array}$ & 4000 & 562 \\
\hline 1. $0^{\prime \prime}$ Insulation & & 581 \\
\hline
\end{tabular}

NOTES:

Well-bottom temperature $=600^{\circ} \mathrm{F}$

Well head injection temperature $=100^{\circ} \mathrm{F}$

$300,00 \mathrm{lb} / \mathrm{hr}$ flow

Sp. Ht. steam/Sp. Ht. water $=0.7$

For the case of an uninsulated 4-inch diameter injection pipe $4000 \mathrm{ft}$ long, the exit steam temperature is calculated to be $332 \mathrm{~F}$. The degradation in temperature at the well head due to loss of heat from the hot steam to the cold water was $600-332=268^{\circ} \mathrm{F}$. This produces a $53 \%$ reduction in heat flow from the well. A 6-inch pipe of the same length would produce steam at a temperature of $259^{\circ} \mathrm{F}$, resulting in a $68 \%$ loss in heat flow from the well. The effect of applying a small amount of thermal insulation between the hot and cold streams is significant. One-half inch of thermal insulation reduces the heat loss to less than $2 \%$. No effort was made to investigate the problems associated with applying the thermal insulation. A suitable insulation material probably can be found for application to the inside of the downcomer pipe where it sees only relatively pure water. However, the structural integrity of the insulation and its resistance to spalling with a $500^{\circ} \mathrm{F} \Delta \mathrm{T}$ needs further evaluation.

A more serious problem with the downhole heat exchanger concept is the uncertainty associated with the mechanisms by which the heat is transported from the geothermal strata to the well casing in the absence of large-scale mass transport of the hot brine to the production zone. The only 
mechanism available for driving the brine toward the casing is thermal convection of the brine through the geothermal rock or sand formation. The driving head that can be provided by small density differences is small compared to that generated by vapor pressure or hydrostatic liquid head. It does not appear that the large flow requirements of the well can be established by small density differences generated by temperature gradients. In any event, these will be significant only in the immediate neighborhood of the well casing.

There is also the problem of scale formation on the outside of the casing and its deleterious effect on well production. A 1/4-in. thick deposit $\left(\mathrm{k}=0.5 \mathrm{Btu} / \mathrm{ft}-\mathrm{hr}-{ }^{\circ} \mathrm{F}\right)$ on the outside of a $12-\mathrm{in}$. well casing will transfer $2 \times 10^{7} \mathrm{Btu} / \mathrm{hr}$ for each 1000 feet of casing with a $300^{\circ} \triangle \mathrm{T}$ between the geothermal brine and the wall of the casing. Ten production wells would therefore produce about $40 \times 10^{7} \mathrm{Btu} / \mathrm{hr}$ and $300^{\circ} \mathrm{F}$ water temperature. Comparing this to the $124 \times 10^{7} \mathrm{Btu} / \mathrm{hr}, 420^{\circ} \mathrm{F}$ brine used for the cycle analysis studies in this report, it indicates that significantly more production wells would be required in the downhole heat exchanger system.

The precipitation of silica, both as a scale on the casing and as colloidal particles which may plug the formation is quite possible. A thorough study of the potential flow and scaling problems which can arise with this concept is advisable before a deep well experimental test program is undertaken.

\section{H. Direct Contact Hydrocarbon Vapor Generation}

The direct contact cycle vaporizes the hydrocarbon by injecting it into the hot brine, either in the well or in a high pressure vessel. The mixture of steam and hydrocarbon vapor then passes through a steam purification system to remove the brine droplets that have been entrained by the vapor. If the contacting is done outside the well, the brine must be compressed to the hydrocarbon vapor pressure, assumed to be isobutane at 600 to 100 psia, before it can enter the pressure vessel.

A quick review of this concept does not show any potential performance advantages over the direct steam cycle. All of the technical problem areas external to the well still remain. A high performance mixed vapor 
purification system is required to remove the brine droplets before the vapor can enter the turbine. The purification problem will be magnified if only a few per cent of brine blows out of the well with the mixed vapor. Binary turbine development must consider the flow of mixed vapors through the turbine. The injection pipe must be insulated to limit thermal refluxing area limitations in the well hole may present a flow problem. The isobutane process flow diagram, Figure 9, shows that $4.5 \times 10^{6} \mathrm{lb} / \mathrm{hr}$ of isobutane were required for the turbine system as compared to $2.82 \times 10^{6} \mathrm{lb} / \mathrm{hr}$ of brine and steam from the well. If the isobutane were introduced directly into the well, the downcomers would have to flow $4.5 \times 10^{6} \mathrm{lb}$ of liquid down into the well and the annular upcomer space would have to flow $4.5 \times 10^{6} 1 \mathrm{~b}$ of isobutane vapor out of the well. Thus, the mass flow requirements for each casing would increase by at least a factor of four relative to a brine-steam flow. The economic effect of an increase in well costs needs to be evaluated.

Availability of suitable hydrocarbons for this application may be limited. The well bottom temperatures of $500-600^{\circ} \mathrm{F}$ are well above the permissible operating limit of freon and well above the desirable operating temperature for ammonia vapor. Hydrocarbons that are suitable for the well may not be effective for the turbine.

As an alternative to injection of an immiscible volatile fluid, gas injection has been proposed as a means of bringing geothermal brine out of a well while maintaining pressure (and temperature). The object of such an approach would be to minimize flashing and thereby minimize brine cooling and consequent silica deposition in the well.

At ordinary rates of production, flashing occurs about half way to the surface in geothermal wells. As a result, the fluid in the upper half of the well weighs much less than pure liquid and hydrostatic pressure in the formation at the bottom drives the brine out. The rate stabilizes when well head pressure plus the weight of the fluid in the well plus friction losses in well and formation equals formation pressure. 
With the proposed technique a small amount of gas (e.g., nitrogen) is injected at the very bottom of the well. The bubbles of gas and water vapor decrease the density of the entire fluid column in the well. If the production rate is kept sufficiently low that the frictional losses do not mask the effect of density reduction, an increase in pressure (and temperature) should be seen at the well head. The nitrogen/water vapor mixture would be separated from the hot brine, recompressed, and reinjected. Probably some heat would be extracted first to decrease the volume being compressed.

A rigorous analysis of the operation requires an iterative process to establish the values of all contributions to the pressure balance. Each trial requires an analysis of two phase flow (to establish vapor fraction density and pressure drop) with a heat balance to establish temperature changes. Since such an analysis is beyond the scope of the present program, some gross simplifying assumptions were made. The major assumption is that the average specific gravity of the entire well column is 0.75 for a conventional well (i. e., $50 \%$ voids in 50\% of the length) and 0.5 for a well with gas injection. For such a case the pressure balance might be something like this:

\begin{tabular}{cr}
$\begin{array}{c}\text { Normal Well } \\
\text { (Sinclair No. 3) }\end{array}$ & Gas Injection Well \\
\cline { 2 - 2 } 5200 & 5200 \\
2250 & 2250 \\
180 & 180 \\
2070 & 2070 \\
180 & 270 \\
1690 & 1130 \\
200 & 670
\end{tabular}

1. Depth, ft

2. Formation pressure, psia

3. Formation friction, psi

4. Well Bottom, psia (2-3)

5. Well Friction, psi

6. Well Fluid Weight, psi

7. Well Head Pressure, psia $(4-5-6)$

If it is as sumed that enough inert gas is injected to generate a vapor volume (gas plus water vapor) equal to the brine volume at the bott om of the well, the well head temperature and pressure can be estimated by a trial and error technique. The result is as follows: 
8. Inert Gas Injected, $\mathrm{scf} / \mathrm{lb}$ brine

0.755

9. Assumed Well Head Temp, ${ }^{\circ} \mathrm{F}$

10. Vapor Pressure $\mathrm{H}_{2} \mathrm{O}$ at Well Head, psia

11. Part. Pres. Inert Gas at Well Head, psia

12. Vol. Ratio Gas $/ \mathrm{H}_{2} 0$ Vapor at Well Head (11/10)

0.720

13. Well Bottom Temp, ${ }^{\circ} \mathrm{F}$

14. $\mathrm{H}$, Brine $\left(522^{\circ}\right.$ to $\left.465^{\circ}\right), \mathrm{Btu} / \mathrm{lb}$

38.200

15. Vaporized $\mathrm{H}_{2} 0,1 \mathrm{~b} / \mathrm{lb}$ brine

0.0505

16. Vaporized $\mathrm{H}_{2} \mathrm{O}$, scf/lb brine

1. 065

17. Vol. Ratio Injected Gas/Vaporized $\mathrm{H}_{2} \mathrm{O}(8 / 16)$

0.710

Since Item 17 is about equal to Item 12, the as sumed well head temperature is valid. In such a case, the brine would $\operatorname{cool} 57^{\circ} \mathrm{F}$ as it flows up through the well vs. $132^{\circ}$ for the normal case - with a corresponding reduction in silica precipitation. About 5\% of the water in the brine would evaporate vs. $11 \%$ for the normal case. However, an amount of gas equal to $0.755 \mathrm{scf} / 1 \mathrm{~b}$ brine would have to be compressed from 670 psi to 2070 psi and well production would probably be reduced because of the reduced effective well size for brine flow.

In conclusion, it appears that the injection of an inert gas at the bottom of a geothermal brine well may permit the production of a higher temperature brine and thereby inhibit scale formation in the well. Another benefit could be the availability of some of the heat at a relatively high temperature which may increase conversion efficiency and permit steam superheating to be practiced. The disadvantages of such a system include higher capital and operating costs (due to the gas compression step) possibly higher well corrosion (due to elevated temperatures near the surface) and greater scale formation in surface equipment. Although no economic evaluation has been made, it appears doubt $f$ ul that the potential benefits will outweigh the disadvantages. Nevertheless, the concept represents an interesting possibility and may warrant a simple test or additional study, particularly if mechanical downhole pumps or injection of volatile fluids are to be seriously considered. 


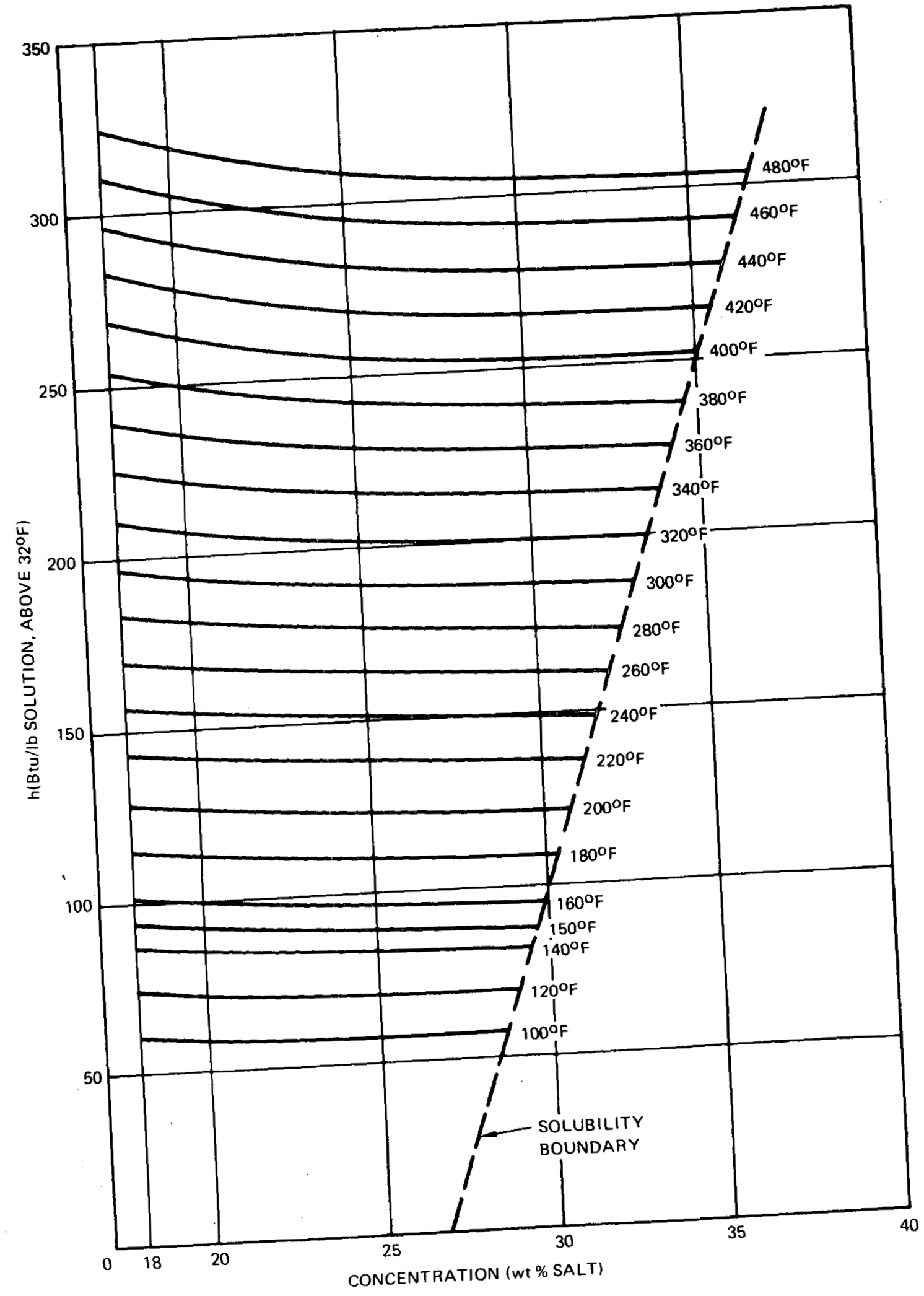

Figure B-1. Enthalpy of Brine 


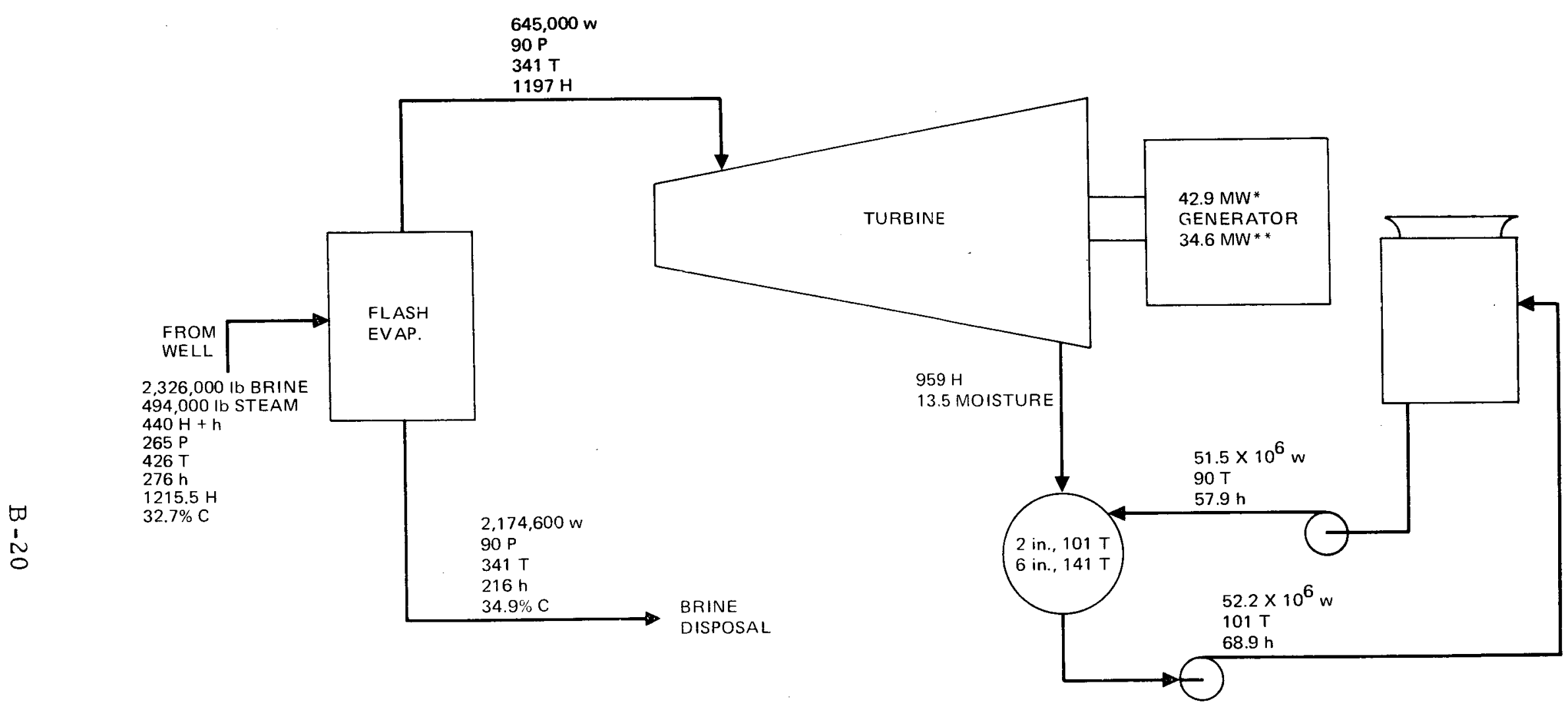

$w=$ Flow Rate $(\mathrm{lb} / \mathrm{hr})$

$H=$ Enthalpy $(B t u / l b \cdot S t e a m)$

$h=$ Enthalpy $(B t u / l b-$ Liquid

$T=$ Temperature $\left({ }^{\circ} \mathrm{F}\right)$

$P=$ Pressure (psia)

$C=$ SALINE CONCENTRATION OF LIOUID

*WET COOLING TOWER (2-in. BACK-PRESSURE)

**DRY COOLING TOWER (6-in. BACK-PRESSURE)

Figure B-2. Direct Steam Cycle - l Stage 


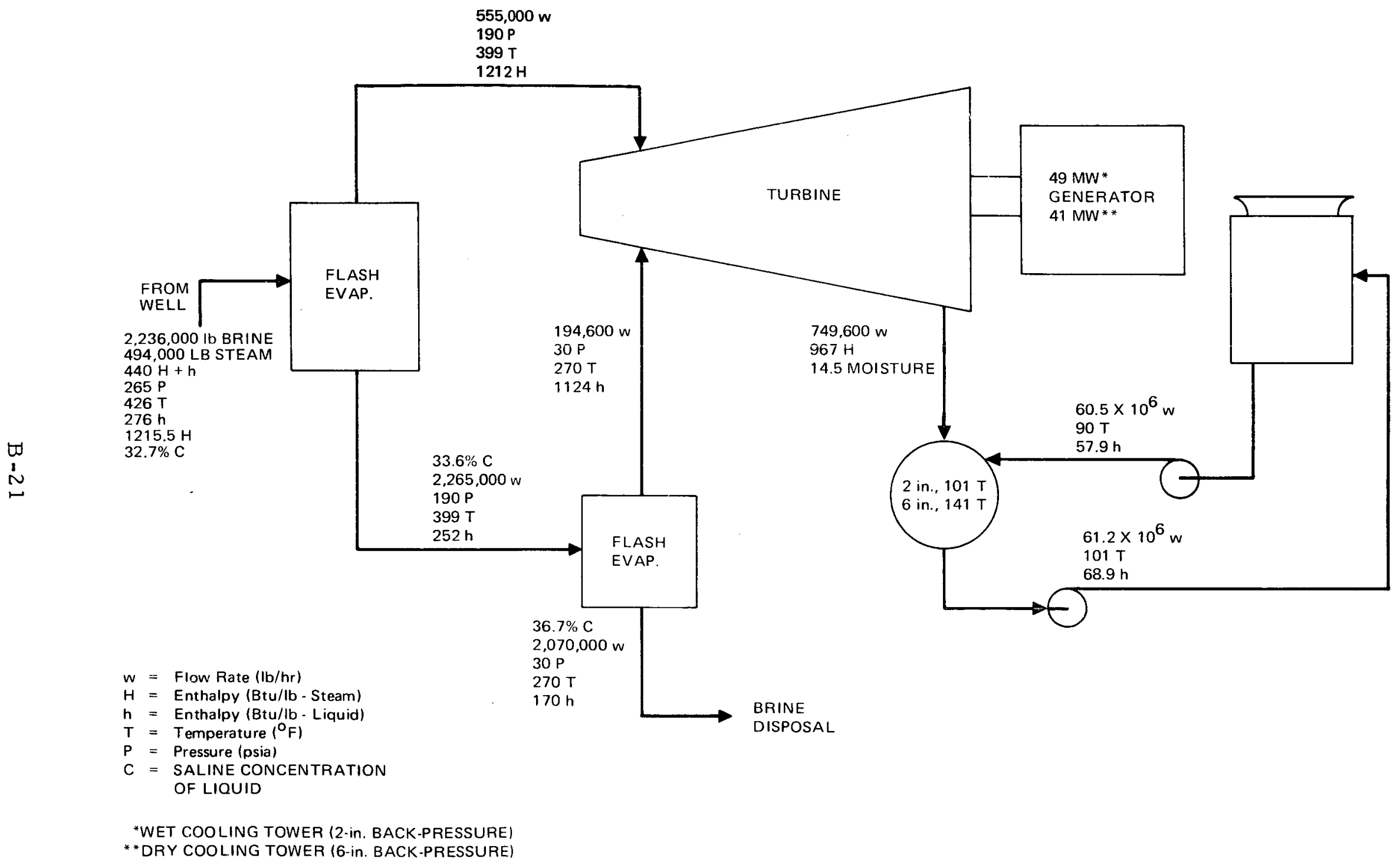

Figure B-3. Direct Steam Cycle - 2 Stages 


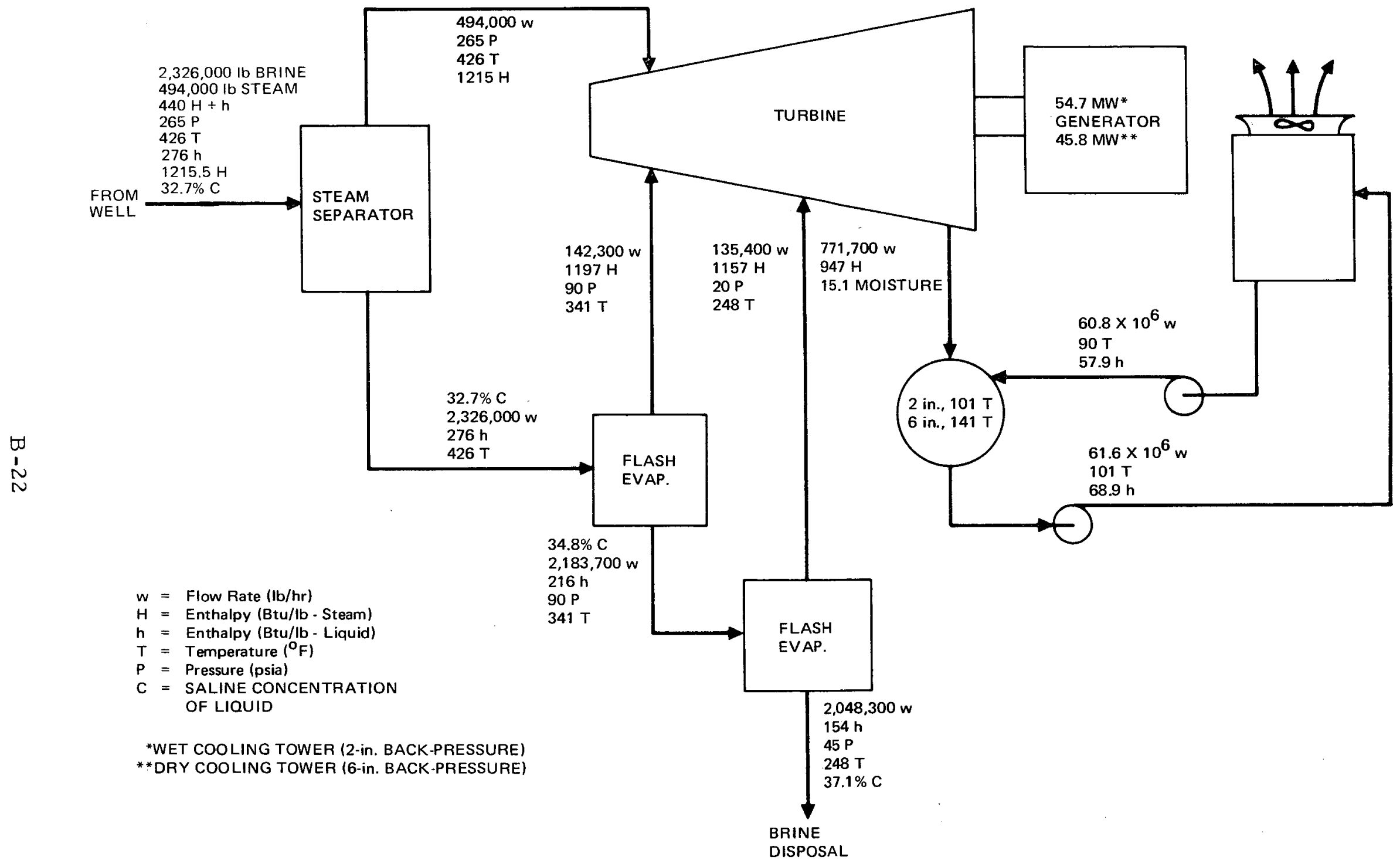

Figure B-4. Direct Steam Cycle - 3 Stages 


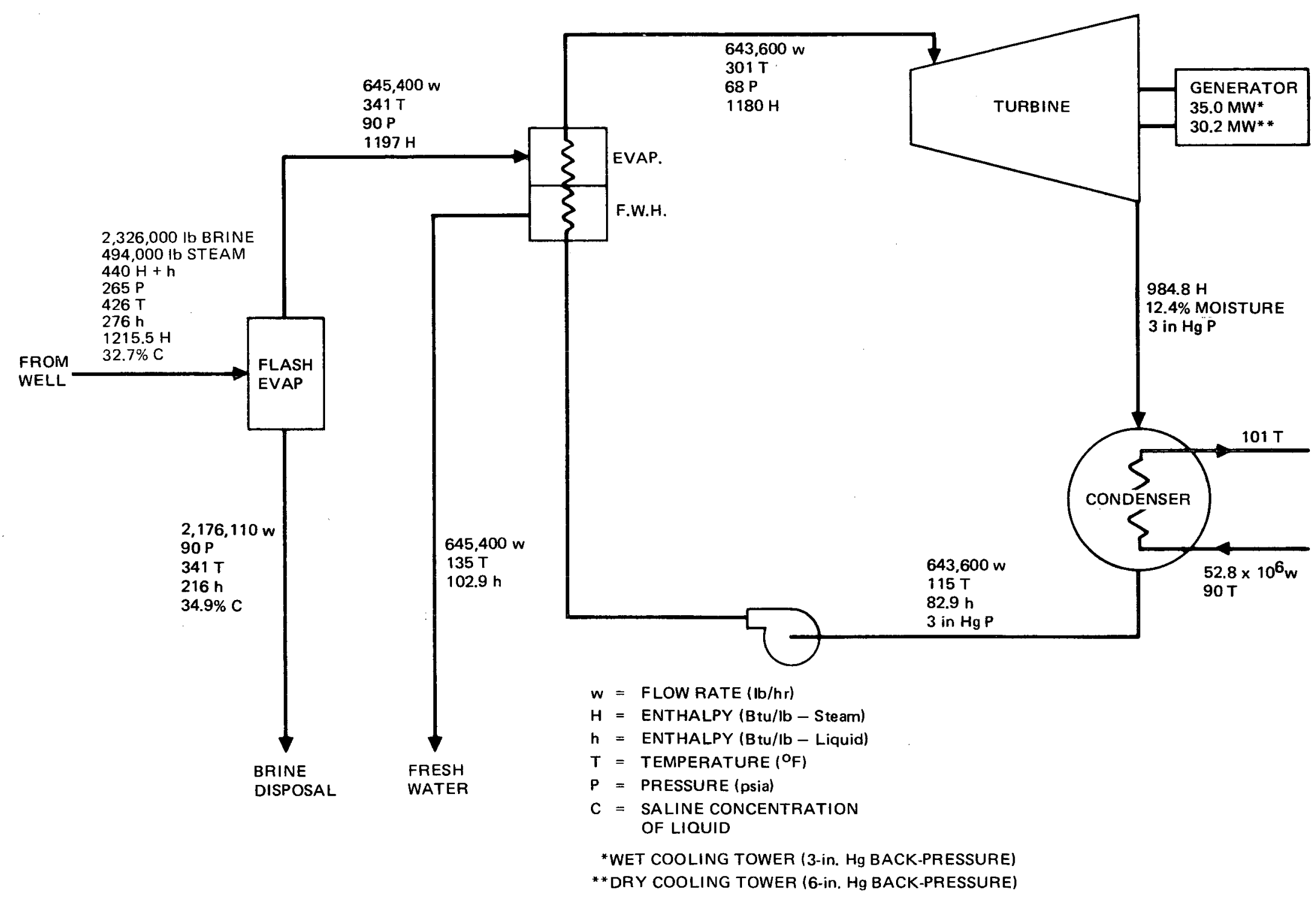

Figure B-5. Steam-to-Steam Cycle - 1 Stage 


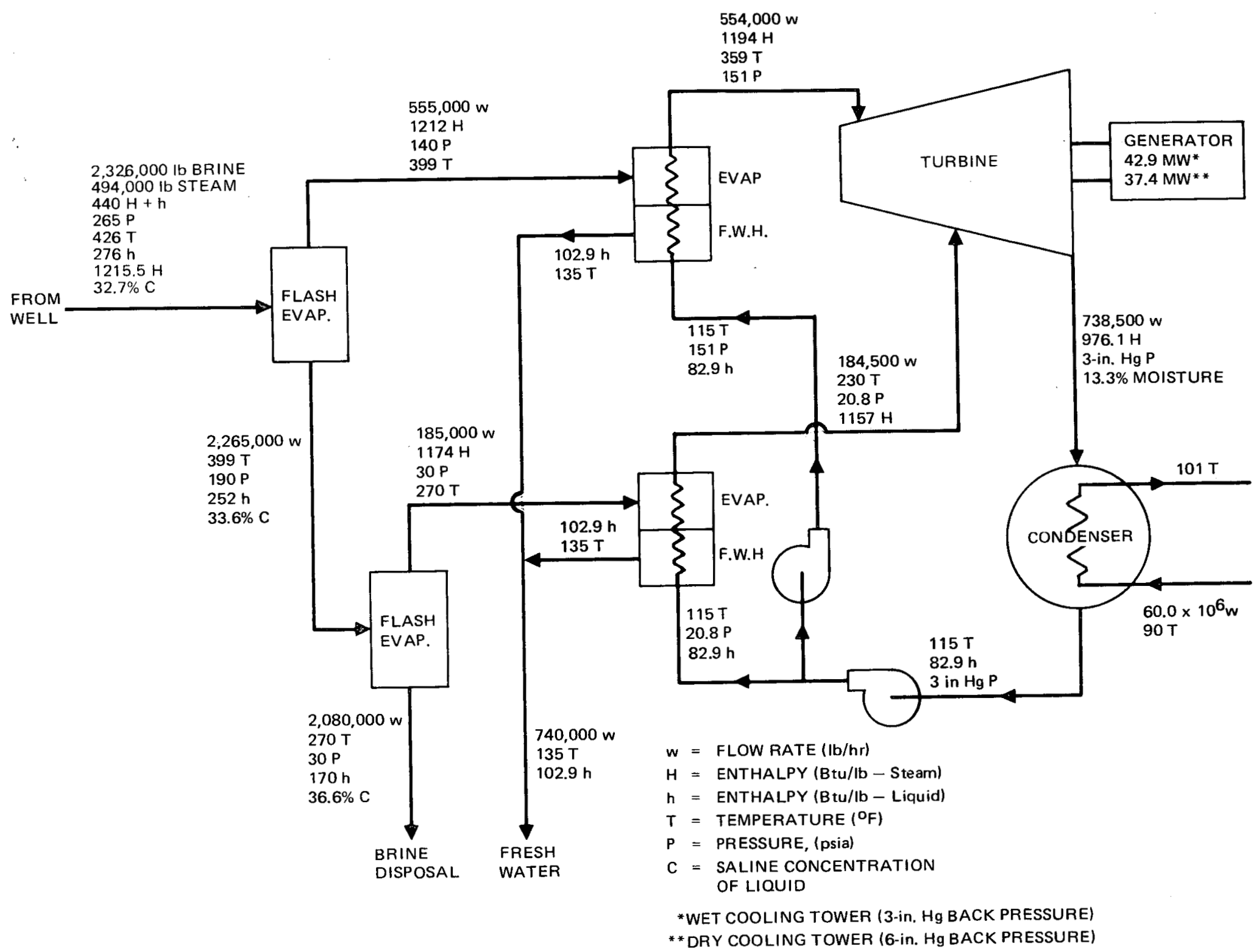

Figure B-6. Steam-to-Steam Cycle - 2 Stages 


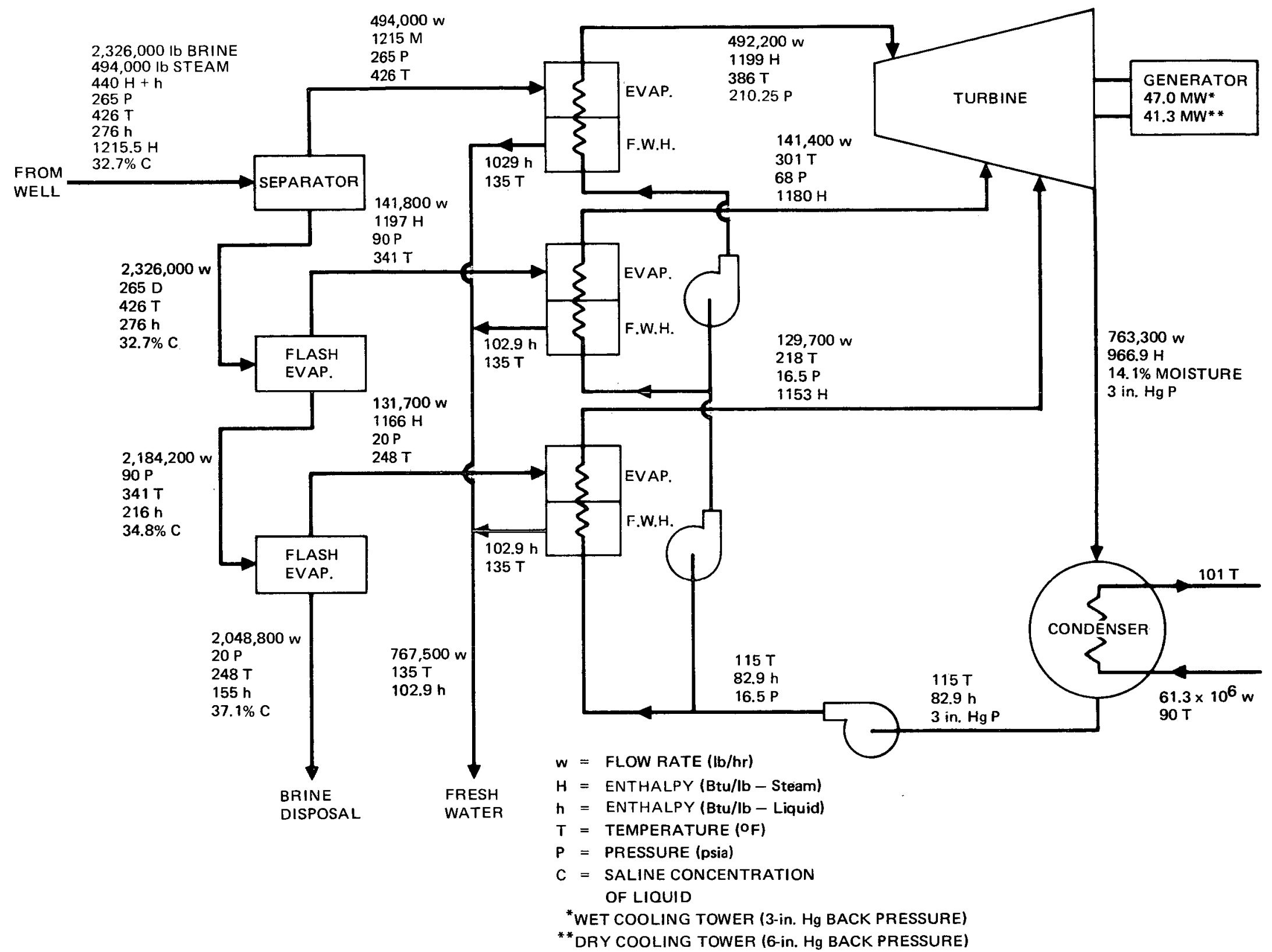

Figure B-7. Steam-to-Steam Cycle-3 Stages 


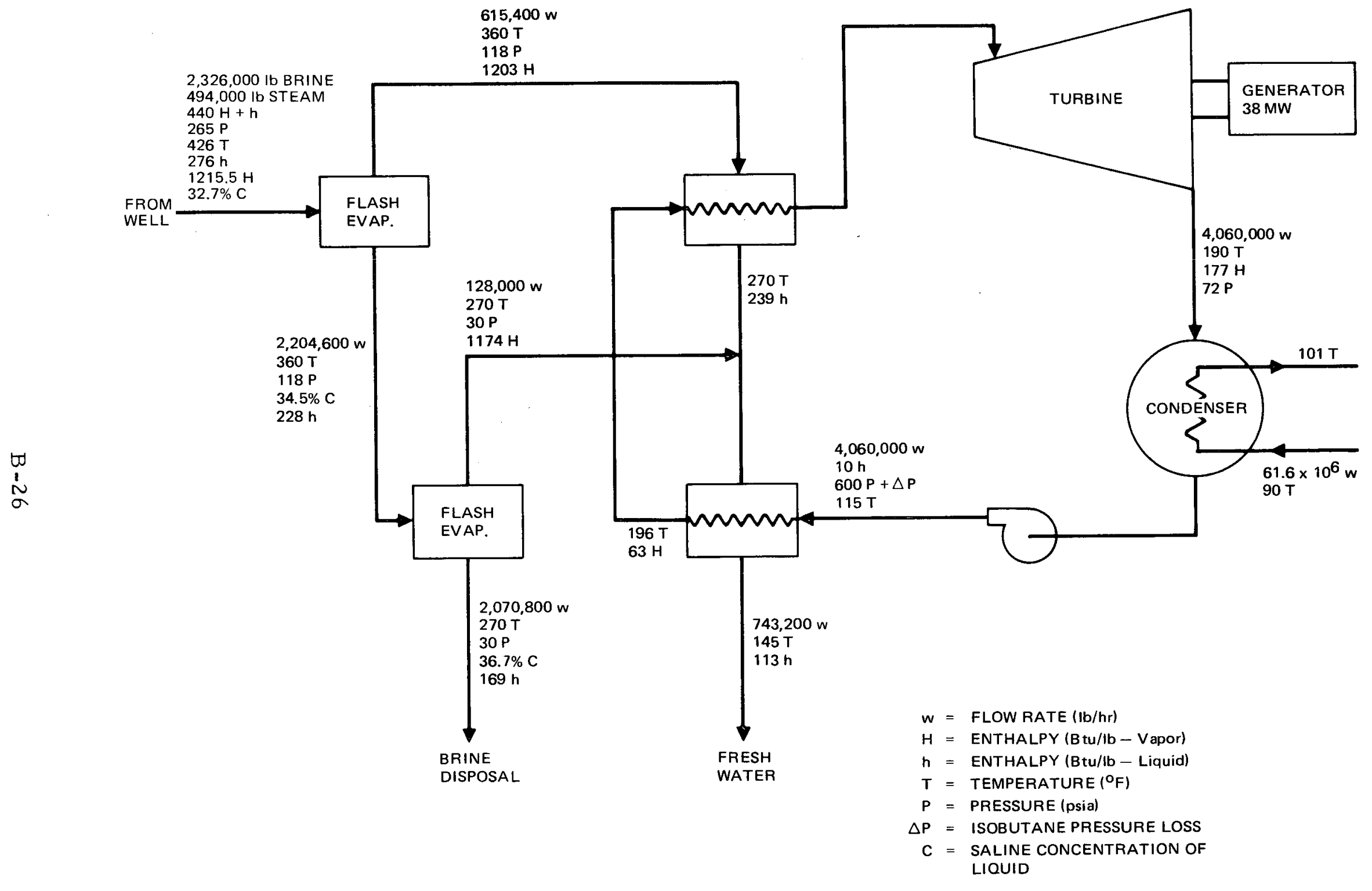

Figure B-8. Steam-to-Isobutane Cycle-2 Flash Stages 


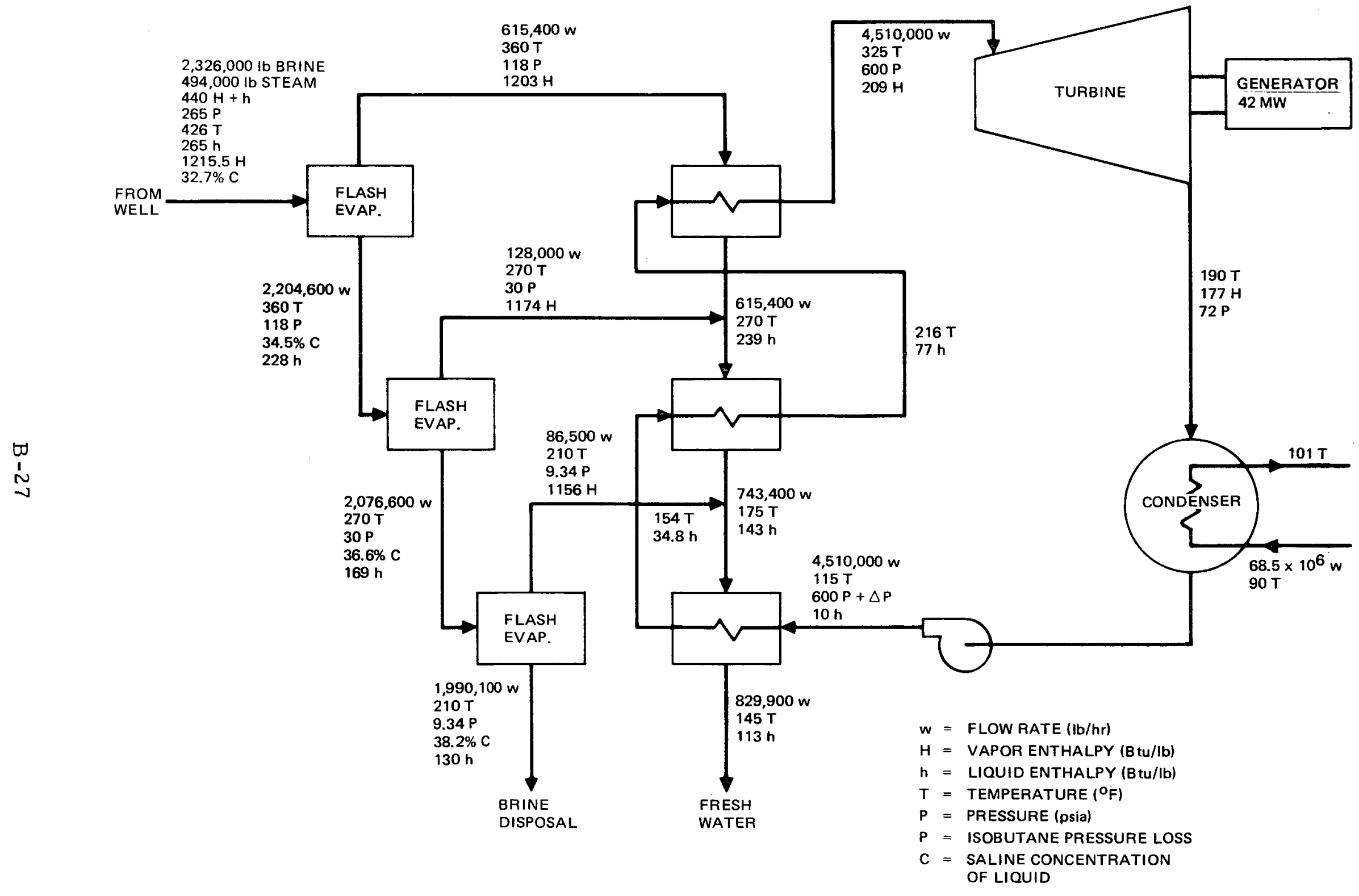

Figure B-9. Steam-to-Isobutane Cycle-3 Flash Stages 


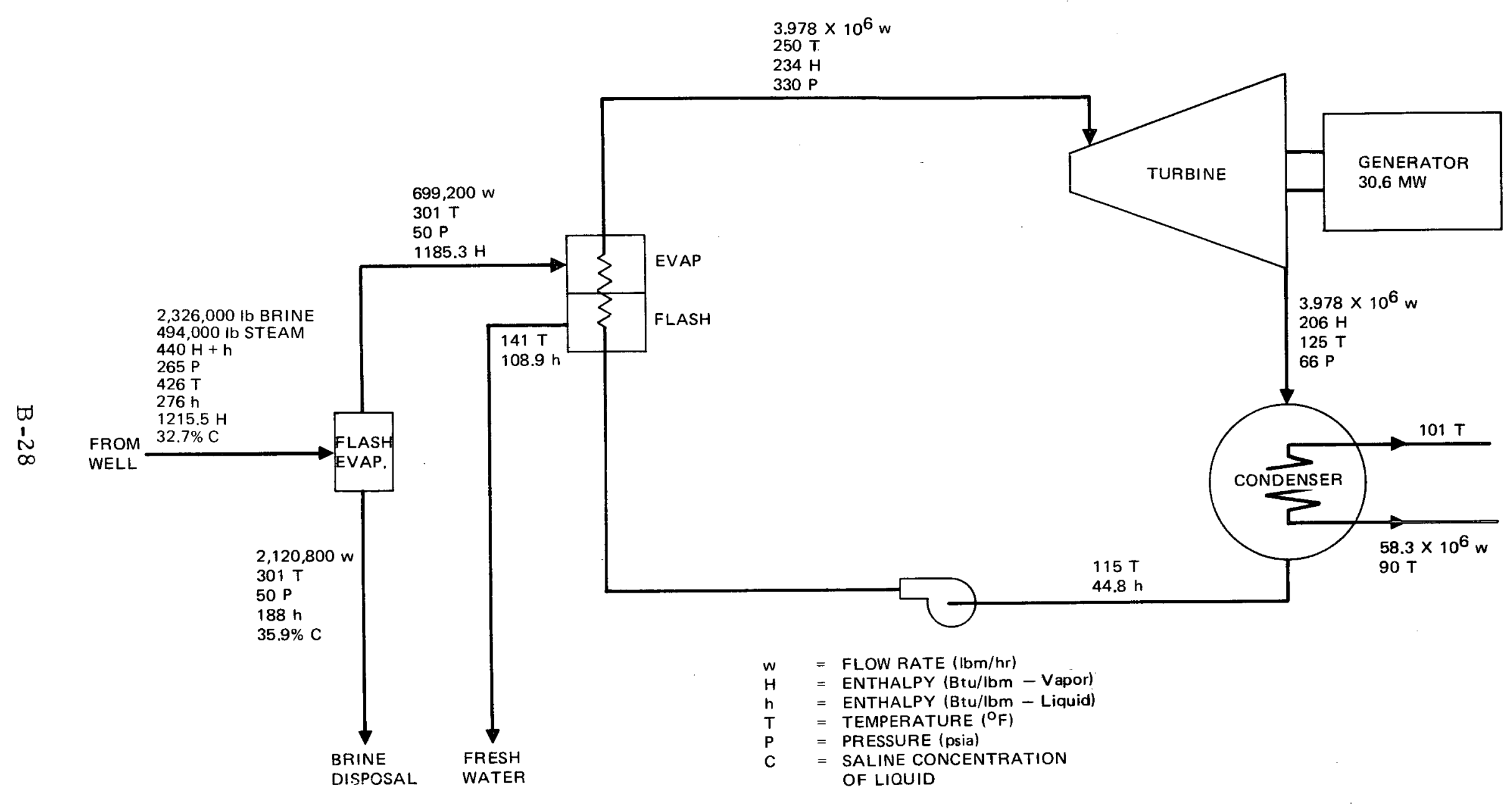

Figure B-10. Steam-to-N-Butane Binary Cycle 


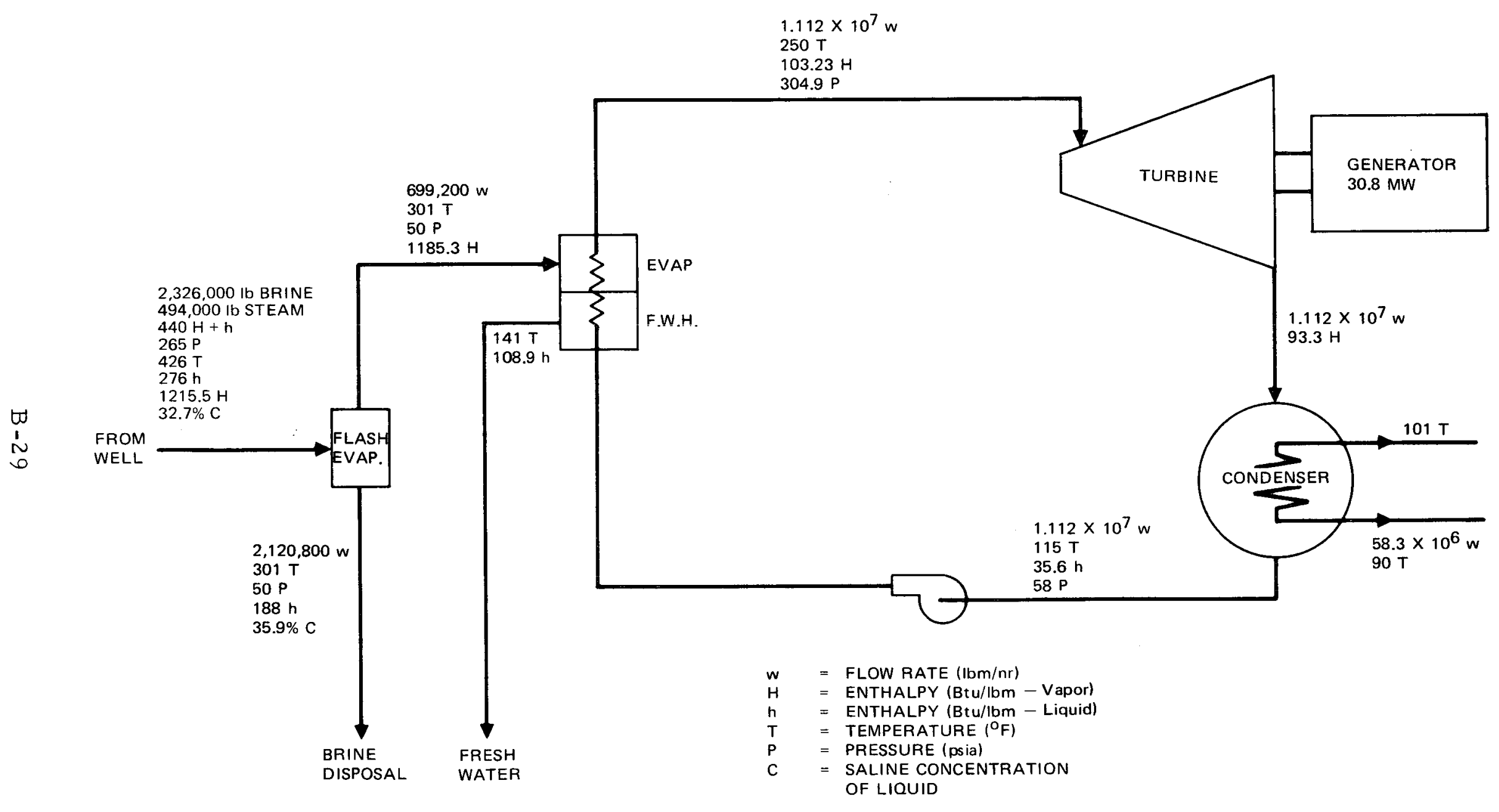

Figure B-11. Steam-to-Freon 114 Binary Cycle 


\section{APPENDIX C}

BIBLIOGRAPHY - ENVIRONMENTAL ANALYSIS

$$
\text { C }-1
$$



Allen, T.F.H. (1971). Multivariate approaches to the ecology of algae on terrestrial rock surfaces in North Wales. J. Ecol. 59 (3).

Allen, T.F.H., Koonce, J.F. (1973). Multivariate approaches to algal strategems and tactics in systems analysis of Phytoptankton. Ecology, 54 (6): 1234-1246.

Anderson, A.J.B. (1958). An Introduction to Multivariate Statistical Analysis. Wiley and Sons, New York.

Anderson, A.J.B. (1971a). A similarity measure for mixed attribute types. Nature, Lond., 232, 416-417.

* Anderson, A.J. B. (1971b). Ordination methods in ecology. J. Ecol., 59, 713-726.

Angel, M.V. and Fasham, M.J.R. (1973). Sond Cruise 1965: Factor and duster analysis of the plankton results, a general summary: J. Mar. Biol. Ass. U.K. 53:185-231.

* Austin, M.P. (1971). Role of Regression Analysis in Plant Ecology. Proc. E.S.A., 6. 
Austin, M.P. and P. Greig-Smith. (1968). The application of quantilative methods to vegetation survey. II. Some methodological problems of data from rainforest. J. Ecol. $56,827-844$.

* Austin, M.P. and I. Noy-Meir. (1971). The problem of nonlinearity in ordination: experiments with two-gradient models. J. Ecol. 59 (3), 763-773.

Austin, M.P. and L. Orloci. (1966). Geometric models in ecology. II. An evaluation of some ordination techniques. J. Ecol. $54,217-227$

Bayer, F.M., G.L. Voss and C.R. Robins. (1970). Report on the marine fauna and benthic shelf-slope communities of the Isthmian region. Battelle Mem. Inst., Ohio, $94 \mathrm{pp}+331$ appendix +70 figures.

* Beals, E.W. (1973). Ordination: mathematical elegance and ecological naiveté. J. Ecol. GI (1): 23-36.

Benzecri, J.P. (1969). Statistical analysis as a tool to make patterns emerge from data. In S. Watanabe (Ed.). Methodologies of Pattern Recognition, Academic Prcss, New York and London, Pp. $35-7 \cdot 4$. 
* Blackith, R.E. and R.A. Reyment. (1971). Multivariate Morphometrics. Academic Press, New York.

Boesch, D.F. (1973). Classification and Community Structure of Macrobenthos in Hampton Roads Area. Virginia. Marine Biology, 21:226-244.

Bray, J.R. and J.T. Curtis. (1957). An ordination of the upland forest communities of southern Wisconsin. Ecol. Monogr., $27, \quad 325-349$.

Brillouin, L. (1962). Science and Information Theory, 2nd ed., Academic Press, New York.

Burr, E.J. (1968). Cluster sorting with mixed character types.

I. Standardization of character values. Aust. Comput. J., 1, 97-99.

Burr, E. J. (1970). Cluster sorting with mixed character types. II. Fusion strategies. Aust. Comput. J., 2, 98-103.

Buzas, M.A. and T.G. Gibson. (1969). Species diversity: Benthic Foraminifora in western North Atlantic. Science, New York., $163,72-75$. 
Cassie, R. M. (1961b). Frequency distribution models in the ecology of plankton and other organisms. J. anim. Ecol., $31,65-92$.

Cassie, R.M. (1963). Multivariate analysis in the interpretation of numerical plankton data. N. Zealand J. Sci., 6, 36-59.

Cassie, R. M. (1972). A computer programme for multivariate statistical analysis of ecological data. J. exp. mar. Biol. Ecol.: 10: 207-241.

Cassie, R.M. and A.D. Michael. (1968). Fauna and sediments of an intertidal mud flat: a multivariate analysis. J. exp, mar. Biol. Ecol., 2, 1-23.

Cheetham, A.H. and J.E. Hazel. (196.9). Binary (presence/absence) similarity coefficients. J. Paleontol., 43, $1130-1136$.

Dale, M.B. and D.J. Anderson. (1972). Qualitative and quantitative information analysis. J. Ecol. GO (3): 639-654.

Dale, M.B., G. N. Lance and L. Albrecht. (1971). Extensions to information analysis. Aust. Comput.J., 3, 29-34. 
Day, J.H., J.G. Field and Mary P. Montgomery. (1971). The use of numerical methods to determine the distribution of the benthic fauna across the continental shelf off North Carolina. J. anim. Ecol., 40, 93-123.

Dickman, M. (1968). Some indices of diversity. Ecology, 49, $\quad 1191-1193$.

Ebeling, A.W., R. M. Ibara, R.J. Lavenberg and F.J. Rohlf. (1970). Ecological groups of deep-sea animals off Southern California. Bull. Los Ang. County Mus. nat. Hist. Sci., $6, \quad 1-43$

Edden, Anne C. (1971). A measure of species diversity related to the lognormal distribution of individuals among species. J. exp.mar. Biol. Ecol., 6, 199-209.

Edye, L.A., W.T. Williams and A.J. Pritchard. (1970). A numerical analysis of variation patterns in Australian introductions of Glycine wightii (G. javanica). Aust. J. Agric. Res., 71, 57-69.

Eisma, D. (1966). The distribution of benthic marine molluscs off the main dutch coast. Netherlands Journal of Sea Research: 3 (1): $107-163$ 
Erman, D.C. and W.T. HClm. (1971). Comparison of some species importance valves and ordination techniques used to analyze benthic invertebrate communities. OIKOS 22: $240-247$.

Fager, E.W. (1957). Determination and analysis of recurrent groups. Ecology, 38, 586-593.

Fager, E.W. (1963). Communities of organisms. In M.N. Hill (Ed.), The Sea. Ideas and Observations on Progress in the Study of the Seas, Interscience, Wiley, New York, 415-433.

Fager, E.W. (1968). The community of invertebrates in decaying oak wood. J. anim. Ecol., 37, 121-142.

Fager, E.W. and A.R. Longhurst. (1968). Recurrent group analysis of species assemblages of demersal fish in the Gulf of Guinea. J. Fish. Res. Bd. Canada, 25, 1405-1421.

Fager, E.W. and J. McGowan. (1963). Zooplankton species groups in the North Pacific. Science, N.Y., 140, 453-460.

Field, J.G. (1969). The use of the information statistic in the numerical classification of heterogeneous systems. J. Ecol., 57, 565-569. 
Ficld, J.G. (1970). The use of numerical methods to determine benthic distribution patterns from dredgings in False Bay. Trans. Roy. Soc. S: Airica, 39 (2), 183-200.

Field, J.G. (1971). A numerical analysis of changes in the solfbottom fauna along a transect across False Bay, South Africa. J. exp. mar. Biol. Ecol. , 7, 215-253.

Field, J.G. and G. Macfarlane. (1968). Numerical methods in marine ecology. I. A quantitative "similarity" analysis of rocky shore samples in False Bay, South Africa. Zool. Afr., 3, 119-137.

Field, J.G. and R.T. Robb. (1970). Numerical methods in marine ecology. II. Gradient analysis of rocky shore samples from False Bay. Zool. Afr., 5, 191-210.

Fisher, D.R. (1968). A study of faunal resemblance using numerical taxonomy and factor analysis. Syst. Zool., 17 (1), 48-63.

$\therefore$ Fisher, L. and J.W. vanNess. (1971). Admissable clustering procedures. Biometrika, 58 (1), 91-104.

Frey, T. and vanGadenewould. (1972). A cluster analysis of the D'matrix of white spruce stands in Saskatchewan based on the maximum-minimum principle. J.Ecol. 60 (3):873-886.

$\therefore$ Gatuch, H.G. Jr. (1273). A quantitative evaluation of the Bray-Curti!; ordination. Fcolosy, $54(4): 829-836$. 
Gauch, H.G. and R.H. Whittaker. (1972). Comparison of ordination techniques. Ecology 53:446-451.

Goodall, D.W. (1970). Statistical Plant Ecology. Ann. Rev. of Sys. and Ecol. 1: 99-124.

Gower, J.C. (1966). Some distance properties of latent root and vector methods used in multivarate analysis. Biometrika, $53,325-338$.

Gower, J.C. (1967). Multivariate analysis and multidimensional geometry. The Statistician, 17, 13-28.

Green, Roger. (1972). Distribution and Morphological variation of Lampslis radiata. J. Fish. Res. Bd. Canada. 29: 1565-1570.

Greig-Smith, P. (1964). Quantitative Plant Ecology, 2nd ed. Butterworths, London.

$\checkmark$ Greig-Smith, P., M.P. Austin and T.C. Whitmore. (1967). The application of quantitalive methods to vegetation survey. J. Association-analysis and principal component ordination of rain forest. J. Ecol., 55, 483-503.

Griffins, R. (1968). Trend-surface analysis in ecology. J. Ecol., 56 (3), 845-869. 
Hagmeier, E.M. (1966). A numerical analysis of the distributional pattern of north American mammals. Syst. Zool., 15, 279-299.

Hagmeier, E. M. and C.D. Stults. '(1964). A numerical analysis of the distributional patterns of north American mammals. Syst. Zool., 13, 125-155.

Hemmings, S.K. and J. Rostren. (1972). A multivariate analysis on the Scottish Middle Old Red Sandstone antiarch fish genus Pterichthyodes Bleeber. Biol. J. Linn. Soc., 4, 15-28.

Hollano, P.G. (1972). The pattern of species density of old stone walls in western Ireland. J. Ecol. 60 (3): 799-806.

Jones, D.J. $(19$ Variation in the Tropic Structure and Species Composition of some Invertebrate Communities in Polluted kelp forests in the North Sea. Marine Biology. 20: 351-365.

Jones, G. F. (1969). The benthic macrofauna of the mainland shelf of southern California. Allan Hancock Monogr. Mar. Biol., $4,1-219$

Kikkaiva, J. (1968). Ecological association of bird species and habitats in eastern Australia; similarity analysis. J. anim. Ecol., 37, 143-165. 
Kikkawa, J. and Kay Pcarse. (1969). Geographical distribution of land birds in Australia - a numerical analysis. Aust. J. Zool., 17, 821-840.

Kikkawa, J. and W.T. Williams. (1971). Ecological grouping of species for conservation of land birds in New Guinea. Search, 2(2), 66-69.

Lambert, J.M. and M.B. Dale. (1964). The use of statistics in phytosociology. Adv. ecol. Res., 2, 59-99.

$\therefore$ Lambert, J.M. and W.T. Williams. (1962). Multivariate methods in plant ecology. IV. Nodal analysis. J. Ecol., 50, $775-802$

Lance, G. N. and W.T. Williams. (1965). Computer programs for monothetic classification. ("Association analysis"). Comput. J., 8, 246-249.

Lance, G.N. and W.T. Williams. (1966a). Computer programs for hierarchial polythetic classification ("Similarity analysis"). Comput. J., 9, 60-64.

Lance, G.N. and W.T. Williams. (1966b). A generalized sorting strategy for computer classifications. Nature, 212, 218. 
Lance, G.N. and W.T. Williams. (1967a). A general theory of classificatory sorting strategies. I. Hierarchial systems. Comput. J., 9, 373-380.

Lance, G.N. and W.T. Williams. (196́7b). Mixed-data classificatory programs. I. Agglomerative systems. Aust. Comput. J., $1,15-20$

Lance, G.N. and W.T. Wrilliams. (1968a). Mixed-data classificatory programs. II. Divisive systems. Aust. Comput. J., 1, 82-85.

Lance, G. N. and W.T. Williams. (1968b). Note on a new informationstatistic classificatory program. Comput. J., 11, 195.

Lance, G.N. and W.T. Williams. (1971). A note on a new divisive classificatory program for mixed data. Comput. J., 14 (2), $154-155$.

Lie, U. and J.C. Kelley. (1970). Benthic infauna communities off the coast of Washington and in Puget Sound: identification and distribution of the communities. I. Fish. res. Bd. Can., $27,621-651$

Lic, U. and D.S. Kisher. (1970). Species composition and structure of benthic infauna communities off the coast of Washington. J. Fisheries Rescarch Board of Canada: 27 (12) $2273-2285$. 
Lloyd, M. and R.J. Ghelardi. (1964). A table for calculating the "equitability" component of species diversity. J. anim. Ecol., 33, 217-225.

Lloyd, M., J.H. Zar and J.R. Karr. (1968). On the calculation of information-theoretical measures of diversity. Am. Midl. Nat., 79, 257-272.

Macnaughton-Smith, P., W.T. Williams, M.B. Dale and L.G. Mockett. (1964). Dissimilarity analysis: a new technique of hierarchial subdivision. Nature, 202, 1034-1035.

Macnaughton-Smith, P. (1965). Some statistical and other numerical techniques for classifying individuals. Home Ofíce. Studies in the causes of delinquency and the treatment of offenders. No. 6, H.M.S.O., London, pp. I-33.

Nichols, F.H. (1970). Benthic Polychaete assemblages and their relationship to the sediment in Port Madison Washington. Marine Biology, 6:48-57.

Noy-Meir, I. (1970) Component analysis of semi-arid vegetation in southeastern Australia. Ph. D. thesis, Australian National University. 
Noy-Mcir, I. and M.P. Austin. (1970). Principal component ordination and simulated vegetation data. Ecology. $51,551-552$.

Noy-Meir, I. (1973). Data transformations in ecological ordination.

I. some advantages of non-centering. J. Ecology.

$61: 329-342$

Orloci, L. (1966). Geometric modcls in ecology. I The theory and application of some ordination methods. J. Ecol., $54,193-215$

Orloci, L. (1967a). Data centering: a review and evaluation with reference to component analysis. Syst. Zool., 16, 208-212.

Orloci, L. (1967b). An agglomerative method for classification of plant communities. J. Ecol., 55, 193-206.

Orloci, L. (1969). Information analysis of structure in biological collections. Nature, 223, 483-484.

Peters, J.A. (1971). A new approach in the analysis of biogeographic data. Smithson. Contrib. 7,001., 107, 1-28.

Pielou, E.C. (1966). Species-diversity and pattern-diversity in the study of ecological succession. J. Theor. Biol.. $10,370 \cdot 383$ 
Pielou, E.C. (1967). The use of information theory in the study of the diversity of biological populations. Proc. Fifth Berkeley Symp. Math. Statist. Probab., 4, 163-177.

Pielou, E.C. (1969). An Introduction to Mathematical Ecology, Wiley-Interscience, New York.

Poore, M.E.D. (1955b). The use of phytosociological methods in ecological investigations. II. Practical issues involved in an attempt to apply the Braun-Blanquet system. I. Ecol., $43,245-269$.

Poore, M.E.D. (1955c). The use of phytosociological methods in ecological investigations. III. Practical applications. J. Ecol., 43, 606-651.

Popham, J.D. and D.V. Ellis. (1971). A comparison of traditional, cluster and $Z$ urich-Montpellier analysis of infaunal pelecypod associations from two adjaccnt sediment beds. Mar. Biol., 8 (3), 26́0-266.

Pritchard, N.M. and A.J.B. Anderson. (1971). Observations on the use of cluster analysis in botany with an ecological example. J. Ecol., 59 (3), 727-747.

Ricker, W.E. (1973). Linear regressions in fishery research. Iournal Fish. Res. Bd. Camada, 30 (3). 
Russel, G. (1973). Phytosociological studies on a two zone shore. II. Community structure, J. Ecol. 61 (2):525-536.

Seal, H.I. (1964). Multivariate Statistical Analysis for Biologists, Metheun, London.

Smith, R.W. (1973). Numerical analysis of a benthic transect in the vicinity of waste discharges in outer Los Angeles Harbor. Marine Studies of San Pedro Bay, Par II. 195-237.

Sokal, R.R. and P.H.A. Sneath. (1963). Principles of Numorical Taxonomy, Freeman, San Francisco.

Stephenson, W. and W.T. Williams. (1971). A study of the benthos of soft bottoms, Sek Harbour, New Guinea, using numerical analyeis. Aust. J. mar. Freshwat. Res., 22, 11-34.

Stephenson, W., W.T. Williams and S. Cook. (1972). Computer analysis of Petersen's original data on bottom communities. Ecol. Monogr. 42 (4): 387-415.

Stephencon, W., W.T. Williams and G. N. Lance. (1970). The macrobenthos of Moreton Bay. Ecol. Monogr.. 40. 459-484.

Swan, J.M.A. (1970). An examination of Eome ordination problems by use of simulated vegetational data. Ecology. 51, 89-102. 
Tenore, K.R. (1972). Macrobenthos of the Pamlico River Estuary, North Carolina. Ecol. Monogr., 42, 51-69.

Webb, L.J., J.G. Tracey, W.T. Williams and G. N. Lance. (1967). Studies in the numerical analysis of complex rain-forest communities. I. A comparison of methods applicable to site/species data. J. Eco1., 55, 171-191.

Webb, L.J., J.G. Tracey, W.T. Williams and G. N. Lance. (1971). Prediction of agricultural potential from intact forest vegetation. J. Appl. Ecol., 8, 99-121.

Webb, L.J., J.G. Tracey and W.T. Williams. (1972). Regeneration and pattern in the subtropical rain forest. J. Ecol. $60(3): 675-696$.

Williams, W. T. (1971). Principles of clustering. Ann.rev. ecol. syst., $2,303-326$.

Williams, W.T., H.T. Clifford and G.N. Lance. (1971). Groupsize dependence: a rationale for choice between numerical classifications. Comput. J., 14 (2), 157-162.

Williams, W.T., L.A. Foye. R. Burt an: B. Gref. (1973). The use of ordination techniques in preiminary evaluations of Stylosanthes accessions. 
Williams, W.T. and J.M. Lambert. (1959). Multivariate methods in plant ecology. I. Association-analysis in plant communities. J. Ecol., 47, 83-101.

Williams, W.T. and J.M. Lambert. (1962). Multivariate methods in plant ecology. II. The use of an electronic digital computer for association-analysis. J. Ecol., 48, 689-710.

Williams, W. T. and J.M. Lambert. (1961a). Nodal analysis of associated populations. Nature, 191, 202.

Williams, W.T. and J.M. Lambert. (1961c). Multivariate methods in plant ecology. III. Inverse as sociation analysis. J. Ecol. , 49, 717-729.

Williams, W.T., J.M. Lambert and G. N. Lance. (1966). Multivariate methods in plant ecology. V. Similarity analysis and information-analysis. J. Ecol., 54, 427-446.

Williams, W.T. and G.N. Lance (1965). Logic of computerbased intrinsic classifications. Nature, 207, 159-161.

Williams, W.T., G.N. Lance, L.J. Webb, J.G. Tracey and J.H. Connell. (1969). Studies in the numerical amalysis of complex rain-forest communities. IV. A method for the elucidation of small-scalc forest pattern. J. Ecol., $5 \%, 635-6,54$ 
Williams, W.T., G.N. Lance, L.J. Webb and J.G. Tracey. (1973).

Studies in the numerical analysis of complex rain-forest communities. VI. Models for the classification of quantitative data. J. Ecol., 61 (1): 47-70. 
Cochran, W. G. (1963). Sampling Techniques. John Wiley \& Sons N.Y.

Crinnel1, J. and A. H. Miller. (1944). The distribution of birds of California. Cooper Oriwith. Berkeley.

Todd, R. L. (1969). Arizona Game and Fish Department. Non-Game Investigators. 1968-69. P-RW-53-R1 Compl. Rep. April 1969.

Tomlinson, R. E. and R. L. Todd. (1973). Distribution of two clapper rail races as determined by responses to taped calls. The Condor 34(2):177-183.

U. S. Department of the Interior. (1973). Threatened Wildlife of the United States. Bur. Sport Fish. Wild1. Resource Pap1. 114.

Wilbur, S. R. (1973). The literature of the California black rail. Office of Endangered Species. Bur. of Sport Fisheries and Wildlife. Department of the Interior. Washington D.C. 
APPENDIXD

RESUMES

D- 1 


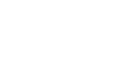




\section{J. LYNN RASBAND - Supervising Research Engineer, Southern California Edison Company}

\section{$\underline{\text { EDUCATION }}$}

1965 Brigham Young University; B.S., Mechanical Engineering

1968-1973 UCLA, Princeton University, Arizona State University; courses in electric energy production.

1971 Pepperdine University; Introduction to Theory and Practice of Management.

\section{EXPERIENCE}

Southern California Edison Company ( 9 years)

December, 1972 to

Present

February, 1972 to

December, 1972

August, 1971 to

February, 1972

June, 1969 to

August, 1971

February, 1968 to June, 1969
Supervising Research Engineer responsible for the work of three engineers in the areas of geothermal, fuel cell development, alternate cooling, and solid wastes utilization. Present projects include fundamental geothermal experiments in the Imperial Valley of California, design study for a geothermal isobutane cycle (co-sponsored with Magma Energy Co.), feasibility studies for utilizing the energy content of solid wastes, and feasibility study for an ammonia condenser cooling system.

Research Engineer responsible for performing economic studies and making recommendations for Edison participation in several advanced generation concepts. Also coordinated other Edison department work on Research Projects.

Project Manager from conception of the Substation Gas Turbine Project. Prepared economic evaluations and recommendations to obtain management approval for the project. Prepared specifications, evaluated bids, and recommended purchase of 50 - megawatt gas turbine equipment that was recently placed in operation in the Santa Barbara area.

Mechanical Engineer responsible for advanced project studies. Coordinated in-house generation plant siting studies and prepared reports analyzing and comparing the generation sites that were studied. Also, prepared economic studies for central plant concepts as requested by the Marketing Department.

Assistant Mechanical Engineer working on the procurement of major equipment items for the Ormond Beach Generating Station. Prepared specifications, evaluated bids, and recommended purchase of forced draft fans, auxiliary steam boilers, fuel oil storage tanks, fuel forwarding pumps, and other miscellaneous pumps. 


\section{J. LYNN RASBAND (Continued)}

September, 1966 to

February, 1968

June, 1965 to

September, 1966
Assistant Mechanical Engineer working on design, construction, and start-up of a major hot fuel oil pipeline to transfer oil from refineries and system storage to several generating plants.

Junior and Assistant Mechanical Engineer working on design of air conditioning and water piping systems for several Edison building additions.

\section{SOCIETIES}

American Society of Mechanical Engineers

Pacific Coast Electrical Association

LICENSE

Mechanical Engineer - State of California

INDUSTRY COMMITTEES

Electric Power Research Institute

Advanced Systems Task Force

Electric Power Research Institute

Electrochemical Energy Conversion and Storage Subcommittee

Electric Utility Fuel Cell Development

Program - Member of Technical Committee 


\section{W. CRAIG RACINE - Research Engineer, Southern California Edison Company}

\section{EDUCA TION}

1968 UCLA; B.S., Engineering

1971 UCLA; M.S., Nuclear Engineering

1973 California Institute of Technology; Supervision of Engineers and Technical Personnel

1974 AMR International; Project Management

\section{EXPERIENCE}

1973-Present Southern California Edison Company

Research Engineer

Responsible for evaluating new electric power generation technologies and for testing promising concepts.

1972-1973 Southern California Edison Company

Environmental Planning Engineer

Responsible for preparing environmental reports to be submitted to various regulatory agencies for a $220 \mathrm{kV}$ transmission line and a $750 \mathrm{MW}$ oil-and-gas-fired generating unit. Responsible for developing an environmental inventory of employer's service territory for use in plant and transmission line siting studies. Supervised two people.

1968-1972 Southern California Edison Company Junior and Assistant Mechanical Engineer

Selected the site and nuclear steam supply system type for a large inland nuclear generating station. Performed economic and technical studies for dry vs evaporative cooling systems, dispatch of power plants to minimize $\mathrm{NO}_{\mathrm{x}}$ emissions, selection of generating station unit size, and alternate methods of generating electrical energy while utilizing waste heat. Gave functional direction to from one to three engineers.

\section{SOCIETY}

American Society of Mechanical Engineers

\section{LICENSE}

Mechanical Engineer - State of California

\section{PUBLICATION}

M.S. Thesis Urban Siting of Nuclear Power Plants in Southern California 
IAN ROTHWELL STRAUGHAN - Southern California Edison Company Born: Rockhampton, Queensland, Australia - March 23, 1938 Married: $\quad 1962$ No Children

Undergraduate Education:

B.Sc. Applied Geology

B.Sc. Major Zoology, University of Queensland, 1961

\section{Graduate Education:}

B.Sc. Honors, Zoology, University of Queensland, 1963 Ph.D. Zoology, University of Queensland, 1967

\section{Positions Held:}

$11 / 1958-3 / 1959$

$5 / 1959-12 / 1960$

$1961-1962$

$1961-5 / 1966$

$2 / 1967-9 / 1968$

$9 / 1968-9 / 1970$

$9 / 1970-9 / 1974$

$9 / 1974-$

$9 / 1970$
Research Geologist, Mount Isa Mines

Teaching Assistant, Department of Zoology, University of Queensland

Teaching Fellow, Zoology Department, University of Queensland

Tutor, Zoology, Commonwealth Office of Education

Senior Demonstrator, Zoology Department, University College of Townsville

Visiting Assistant Professor, Department of Biological Sciences, University of Southern California, Los Angeles, California

Assistant Professor, Department of Biological Sciences, University of Southern California, Los Angeles, California

Research Scientist, Research and Development, Southern California Edison Company, Rosemead, California

Research Associate, Los Angeles County Museum of Natural History, Exposition Park, Los Angeles, California 
IAN ROTHWELL STRAUGHAN (Continued)

$9 / 1973$

Director Research, Organization for Tropical Studies, Universidad de Costa Rica, San Jose, California

$1967-68$

Grants and Contracts awarded as principle investigator: C.S.I.R.O. (Australia) Relationship of faunal association to vegetational and abiotic variables

1969

Biological interactions on complex tropical communities (Grant No. 19-69)

1970

Multivariable analysis factors contributing to biotic spacing on the tropics (Penrose Fund Grant No. 5290)

1971

Hawaii Electric Company: The influence of thermal discharge on coral reef communities

$1972-74$

National Science Foundation. Community structure in two tropical lowland ecosystems

Societies and Organizations:

Australian and New Zealand Society for the Advancement of Science 1961 - present

Australian Mammal Society, Qd. Member of Conservation Committee $1963-1968$

Australian Society of Herpetologists, Foundation Committee 1964, Executive Committee 1965 - 1969

Ecological Society of Australia 1965-present

Australian Conservation Foundation 1966--

Royal Society of Queensland 1962-present

Queensland Wildlife Preservation Society, President of Townsville Branch 1968

American Society of Ichthyologists and Herpetologists 1963-present

Ecological Society of America 1967-present

Society for Study of Evolution 1967-present

British Ecological Society 1969-present

Society for the Study of Amphibians and Reptiles 1970-present

(Elected Life Member)

American Association for the Advancement of Science 1971-present Sigma Xi

\section{Other Activities:}

1964

Invited participant, Symposium (ANZAAS) on

"The C'ianging Australian Fauna." 
IAN ROTHWELL STRAUGHAN (Continued)

1966

Invited participant, Symposium (ESA)

"Sociality in Nature."

1968

Invited participant, Symposium (Roy. Soc. Qd.)

"Conservation in the Tropics."

1970

1972

Invited participant, Symposium (Society for the Study of Amphibians and Reptiles) "Evolution of the Anura"

Invited participant, Symposium (Organization for Tropical Studies) "Advances in Tropical Ecology"

Publications Relevant to the Field of Study

1963

Ecological and behavioral interactions between certain species of Queensland Frogs. Thesis. University of Queensland, Brisbane, Australia

1964

The effect of the introduction of the giant American toad (Bufo marinus) on the indigenous amphibian fauna of Queensland Aust. j. Sci. 27

1966

The ecological distribution of Anurans in response to bio-environmental parameters. Occ. Pap. Univ. of Old Press 234 pages. 28 figs and 56 plates

1967

The response of vertebrate faunas to physionomic structural complex in tropical rain forests.

Proc. E.S.A. 1:109-157. With J. Kikkawa

1969

1970

Geographic distribution of the vertebrates in Australiaa numerical analysis. Bull. Roy. Soc. Qld. 4:121 pp.

Ecological grouping of terrestrial vertebrates for conservation purposes in New Guinea. Alm. Report Dept. of Agriculture T.P.N.G. $43 \mathrm{pp}$.

1971

The use of classifactory and ordination analysis in the detection of distribution patterns of amphibians in Costa Rica. Renista Biologia 55:1-76

1971

Trend surface analysis as a tool in understanding mozaic distributions of organisms in the tropics in Advanced Tropical Biology. M. Lloyd ed. U. of C.R. press. Chapter 1:47-82 
IAN ROTHWELL STRAUGHAN (Continued)

1973

The use of ordination techniques in preliminary evaluations of Stylosanthes accessions. C.S.I.R. O. Pub. in Tropical Pastures $6: 157-172$ with R. Burt

1973

The influence of thermal effluent on marine benthic communities. Kane Pt., Oaju, Hawaii - a predictive model from association analysis. Report to Hawaii Electric Company with D. Straughan in press. The analysis of benthic and vegetational associations a series of numerical methods to assess their ability to detect relationships to environmental parameters. J. of Ecology with R. Smith 
ROBERT MARSHALL CHEW - Consultant to Southern California Edison Company

\section{Vital Statistics}

Born 7 October 1923, Wheeling, W. Va.

Married Alice Eleanor Eastlake, Dec. 26, 1946.

Three children.

Education

B.S. Washington \& Jefferson College. Zoology, 1944.

M.S. Univ. of Illinois. Animal Ecology, 1946.

Ph. D. Univ. of Illinois. Animal Ecology \& Physiology, 1948.

Employment

1948-1952. Assistant Professor of Biology, Lawrence College, Appleton, Wisconsin.

1952 -present. University of Southern California, Los Angeles. Professor of Biology since 1967.

Consultantships

1955-1956. U.S. Army Quartermaster Corps \& Johns Hopkins University

1962-1966. Bioastronautics Laboratory, Northrop Space Laboratories, Compton, Calif.

1965-present. Laboratory of Nuclear Medicine \& Radiation Biology, Environmental Division, Univ. California, Los Angeles (without pay)

1965-1970. Collaborator, without pay, National Park Service

1970-1973. Coordinator of Vertebrate Process Studies, Desert Biome, USA/IBP.

1973-present. Consultant on process studies, and member of Executive Committee, Desert Biome, USA/IBP.

1970 -present. Research Associate, without pay, Los Angeles County Museum of Natural History, Dept. of Mammalogy

University Administration and Committees:

1964-1966. Vice Chairman, Dept. of Biological Sciences

1966-1967. Acting Chairman, Dept. of Biological Sciences; Chairman, Graduate Program in Biology 
University Administration and Committees (Cont'd)

1973-1974. Chairman, Graduate Program in Biology.

Various times: Departmental Committees: Executive, Admissions, Budget, Promotions, Library.

Various times: University Committees: Budget, Library, Religious Interests.

Grants and Contracts held as Principal Investigator

NSF 5570. Annual energy metabolism and water balance of a desert community. \$11,300. July 1958-Jan. 1961.

NSF F-8704. A life history study of the round-tailed sting ray. $\$ 5,200$. June 1959-May 1961 .

NIH RG-676A. Infrared analysis of mammalian insensible water loss. $\$ 1,200$. March 1960-Feb. 1961 .

NIH RG 8804. Evaporative water losses of terrestrial vertebrates. $\$ 13,000$. Sept. $1961-$ Dec. 1965.

PHS CC-00103. Ecology and control of Psorophora confinnis. $\$ 23,381$. June 1962-Nov. 1965.

NSF G 19446. Evaporative water losses of terrestrial vertebrates. $\$ 30,200$. Sept. 1961 -June 1967.

NIAID 08284. Ecology of mosquitoes of arid southeastern California. $\$ 144,000$. Jan. 1967-Dec. 1972.

NSF-Utah State University. Desert Biome/International Biological Program.

8421. Validation Site Study, Rock Valley, Nevada. $\$ 2,413$. Jan. 1971 -Dec. 1971 .

0342. $\$ 1,204$. Jan. 1972 -Nec. 1972 .

0343. Effects of density on the population dynamics of Perognathus formosus. \$14,600. Jan. 1972-Dec. 1972. \$20,400. Jan. 1973-Dec. 1973. 0542. $\$ 10,371$. Jan. 1974-Dec. 1974. 
ROBERT MARSHALI CHEW (Continued)

Publications of Robert M. Chew

1951 to 1959

1951. The water exchanges of some small mammals. Ecol. Monogr. 21:215-225. 21:215-225.

1955. The skin and respiratory water losses of Peromyscus maniculatus sonoriensis. Ecology 36:463-467.

1957. and R. T. Hinegardner. Effects of chronic insufficiency of drinking water in white mice. J. Mammalogy 38:361-364.

1958. Water requirements of mice; a basis for control. Pest Control Journal. August $1958.3 \mathrm{p}$.

1958. Reproduction by Dipodomys merriami in captivity. J. Mammalogy 39:597-598.

1959. B. Butterworth and R. Grechman. The effects of fire on the small mammal populations of chaparral. J. Mammalogy 40:253.

1959. Al-Azawi, A. and R. M. Chew. Notes on the ecology of the dark ricefield mosquito, Psorophora confinnis, in Coachella Valley.

Ann. Entomological Soc. Am. 52:345-351.

1959. and $B$. Butterworth. Growth and development of Merriam's kangaroo rat, Dipodomys merriami. Growth 23:75-95.

1959. Estimation of ant colony size by the Lincoln Index method.

J. New York Entomological Soc. 1959:157-161.

\section{0 to 1964}

1960. Porcupines in the Chiricahua Mts., Southeastern Arizona. J. Mammalogy 41:132-133.

1960. Note on colony size and activity in Pogonomyrmex occidentalis (Cresson) J. New York Entomological Soc. 1960:81-82.

1960. and H. E. White. Evaporative water losses of the pallid bad. J. Mammalogy $41: 452-458$.

1961. Water metabolism of desert-inhabiting vertebrates. Biological Reviews $36: 1-31$.

1961. and A. E. Dammann. Evaporative water loss of small

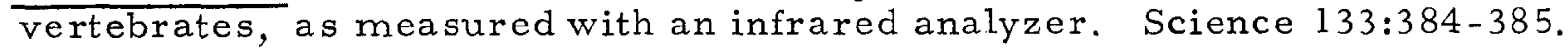




\section{ROBERT MARSHALL CHEW (Continued)}

1961. Ecology of the spiders of a desert community. J. New York Entomological Society. 69:5-41.

1961. Water metabolism of mammals. Succession.

In Encyclopedia of the Biological Sciences. (P. Gray, ed.)

Reinhold Pub. Co.

1964. and S. E. Gunstream. A new medium for rearing the mosquito Psorophora confinnis. Mosquito News 24:22-24.

1964. and B. B. Butterworth. Ecology of rodents in Indian Cove (Mojave Desert), Joshua Tree National Monument, California. J. Mammalogy 45:203-225.

1964. Lindberg, R. G. and R. M. Chew. Metabolic rhythms in the little pocket mouse, Perognathus longimembris. American Zoologists $4(3)$ :abstract 112 .

1964. Gunstream, S.E. and R. M. Chew. Contribution to the ecology of Aedes vexans (Diptera:Culicidae) in the Coachella Valley, California. Ann. Ent. Soc. Am. 57:383-387.

\section{5 to 1969}

1965. Water metabolism of mammals. In Physiological Mammalogy (Mayer and VanGelder, eds.) Vol. 2, Chapter 2, pp. 44-178.

1965. and A. E. Chew. The primary productivity of a desert shrub (Larrea tridentata) community. Ecological Monographs $35: 355-375$.

1965. , R. G. Lindberg and P. Hayden. The circadian metabolic rhythms of pocket mice, particularly Perognathus longimembris. J. Mammalogy 46:477-494.

1965. and $O$. G. Mitchell. Responses of xeric-adapted rodents to waterloading. Proc. Soc. Exp. Biol. Med. 120:336-338.

1966. Gunstream, S. E. and R. M. Chew. The ecology of Psorophora confinnis (Diptera:Culicidae) in southern California. II. Temperature and development. Ann. Entomological Soc. Am. 60:434-439.

1967. Gunstream, S. E. and R. M. Chew. A comparison of mosquito collection by Malaise and miniature light traps. J. Medical Entomology 4:495-496.

1967. , R. G. Lindberg and P. Hayden. Temperature regulation in the little pocket mouse, Perognathus longimembris. Comp. Biochem. Physiol. 21:487-505.

1967. and $E$. Spencer. Development of metabolic response to cold in young mice of fou $r$ species. Comp. Biochem. Physiol. $22: 873-888$. 
ROBERT MARSHALL CHEW (Continued)

1968. Water turnover:Graphic. In Metabolism (P. L. Altman and D. S. Dittmer, eds.) FASEB. Mammals, p. 551-552; Birds, p. 552 (with E. C. Crawford and R. C. Lasiewski); Reptiles, p. 553-554; Amphibians, p. 554-556.

1969. M. H. Smith, R. M. Chew and J. B. Gentry. 1969. New technique for baiting snap traps. Acta Theriologica 14:271.

\section{0 to 1974}

1970. and A. E. Chew. Energy relationships of the mammals of a desert shrub (Larrea tridentata) community. Ecological Monographs $40: 1-21$.

1970.

and S. E. Gunstream. Geographical and seasonal distribution of mosquito species in southeastern California. Mosquito News 30:55l-562.

1971. Chess, T. and R. M. Chew. Weight maintenance of the desert wood rat (Neotoma lepida) on some natural foods. J. Mammalogy 52:193-195.

1971. The excretion of ${ }^{65} \mathrm{Zn}$ and ${ }^{54} \mathrm{Mn}$ as indices of energy metabolism of Peromyscus polionotus. J. Mammalogy 52:337-350.

1971. Gunstream, S. E., R. M. Chew, D. W. Hagstrum and C. H. Tempelis. Feeding patterns of six species of mosquitoes in arid southeastern California. Mosquito News 31:99-101.

1972. Toth, R. S. and R. M. Chew. Development and energetics of Notonecta undulata during predation on Culex tarsalis.

Ann. Ent. Soc. Am. 65(5):12 $\overline{70-1279 .}$

1972. Toth, R. S. and R. M. Chew. Notes on behavior and colonization of Buenoa scimitra (Hemiptera: Notonectidae), a predator of mosquito larvae. Environmental Entomology 1(4):534-535.

1973. Mullen, R. K. and R. M. Chew. Estimating the energy metabolism of free-living Perognathus formosus: a comparison of direct and indirect methods. Ecology 54(3):633-637

1973. and J. G. Hemington. Turnover of Zinc -65 as an index of energy metabolism of Perognathus longimembris, the Little Pocket Mouse. Third National Symposium on Radioecology. May 10-12, 1971. Oak Ridge, Tenn. CONF=710501-P1. p. 247-252.

1974. and J. C. Woodman. Nutritive value of three common chaparral plants for woodrats (Neotoma fuscipes and $\mathrm{N}$. Lepida).

Bull. S. Cal. Acad. Sci. In press. 
ROBERT MARSHALL CHEW (Continued)

1974. Consumers as regulators of ecosystems: an alternative to energetics. Ohio J. Sci. In press.

Technical Reports being prepared for publication:

1973. Chew, R. M., F. B. Turner, P. August, B. Maza and J. Nelson. Effect of density on the population dynamics of Perognathus formosus and its relationships within a desert ecosystem.

Research Memorandum RM 73-18. Desert Biome. USA/IBP.

1974. Chew, R. M. and F. B. Turner. Effect of density on the population dynamics of Perognathus formosus and its relationships within a desert ecosystem.

Research Memorandum. Desert Biome. USA/IBP.

Manuscripts in preparation:

1974. Turner, F. B. and R. M. Chew. The productivity of desert animals. For Desert Biome Symposium Volume. Written by invitation of the editor.

Ecological characteristics of the ants of a desert shrub community.

Nelson, J. and R. M. Chew. Seed reserves in a desert community: Spatial and seasonal variation in relation to vegetation and the density of Perognathus formosus.

Willenborg, M. A. and R. M. Chew. Significance of time of day and method of collection on insect collections from Larrea tridentata.

Ecology of the arthropods of a Larrea tridentata community. 
ROBERT MARSHALL CHEW (Continued)

Seminars 1973-present

March 14-16, 1973. Second Annual Conference. Desert Biome. USA / IBP

May 26, 1973. University of Illinois. Symposium on "Diversity and Functions of Ecosystems". Talk on "Ecosystem dynamics: energetics and other phenomena in desert ecosystems".

Nov. 19-20, 1973. Ohio State University. Symposium on "Energetics and Fitness". Talk on "Consumers as regulators of ecosystems: an alternative to energetics".

Areas of Community Service

Referee for feature articles in Ecology, Ecological Monographs, Journal of Mammalogy, and for research proposals to Environmental Division N.S. F. Few articles refereed for Science, Ann. Entomological Soc. Amer., Environmental Entomology, proposals for B. L.M., N.I.H.

Taught in Experimental College, Santa Monica College, Santa Monica, California.

Amargosa Canyon-Dumont Dunes study committee which prepared survey and recommendations for successful preservation of area by BLM.

Membership in Scientific Societies and Honorary Societies

American Association for Advancement of Science (elected Fellow)

American Ornithological Union

American Society of Mammalogists

British Ecological Society

Ecological Society of America

Entomological Society of America

Southern California Academy of Sciences

Western Society of Naturalists

Phi Beta Kappa

Phi Sigma

Sigma Xi 
S. SUDAR - Project Manager, Environmental and Utility Systems, Advanced Programs Division, Atomics International

EDUCATION

$1943-1946$

$1946-1947$

University of Illinois; B.S., Chemical Engineering

$1957-1967$

Illinois Institute of Technology; Graduate Courses in Engineering

UCLA; Engineering and Management Courses

EXPERIENCE

1956 -Present, Atomics International

1973-Present

Mr. Sudar is presently Project Manager of Energy Systems. He is responsible for company programs in the fields of geothermal power generation, solar energy conversion, energy storage, and internal combustion engine emission control. Mr. Sudar provides technical and programmatic management for assigned programs.

$\underline{1969-1973}$

As member of the technical staff of the Plant Engineering Group of the Nuclear Engineering Department, Mr. Sudar was Project Engineer for development of engine exhaust emission control systems utilizing molten carbonate and catalytic technologies. He also provided engineering consultation for development of hydrogen/oxygen gas recombiners for controlling combustible gases resulting from postulated loss-of-coolant accident and was responsible for analysis of high energy density batteries.

$1956-1969$

Mr. Sudar's positions included Supervisor of Heat Transfer System Development Units involved in the development of components for the AEC's SNAP 10A and SNAP 2 Programs and for the Organic Cooled Reactor Program. His responsibilities included direction of component design, analysis, and testing, and conduction of corrosion test programs. Mr. Sudar has conducted hydraulic and heat transfer analyses of reactor systems and has been responsible for steam generator design and analysis.

\section{PUBLICATIONS}

Mr. Sudar has completed or contributed to numerous technical publications. SOCIETIES - Tau Beta Pi, Pi Mu Epsilon

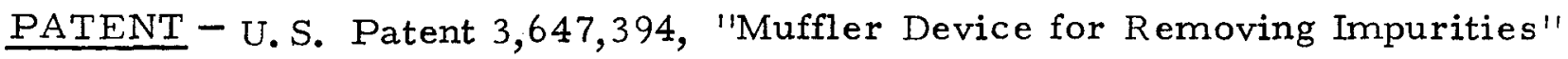


T. H. SPRINGER - Assistant Project Manager, Environmental and Utility Systems, Advanced Programs Division, Atomics International

EDUCATION

$1951-1955$

$1955-1964$

University of Texas; B. A., Physics and Mathematics Extension Courses in Mathematics and Engineering

EXPERIENCE

1955 -Present, Atomics International

$1974-$ Present

Mr. Springer is Assistant Project Manager of Energy Systems and is currently concerned with solar, geothermal, and advanced storage battery energy system.

\section{$1973-1974$}

As a member of the Liquid Metal Fast Breeder Reactor Program Office, Mr. Springer was the Cognizant Engineer Responsible for the system design requirements and the conceptual design of a multi-million dollar Reactor Service Building for the Clinch River Breeder Reactor being constructed by the AEC. This assignment included technical direction, budget and schedule responsibilities, the preparation of detailed program plans, and guidance for the associated A\&E firm.

\section{$\underline{1968-1973}$}

Mr. Springer was Project Engineer (Physics and Safety Technology) on several AEC-funded tasks and one NASA-sponsored program. The combined budgets for these tasks averaged about $\$ 700,000$ per year. His duties as Project Engineer included technical direction, budget and schedule responsibilities, and preparation of periodic and final reports. Mr. Springer was also Principal Scientist on an AED-sponsored Fast Reactor Physics Experiment Program, and was responsible for and participated in experimental and analytical investigations into various fast breeder reactor physics and safety problems such as Doppler coefficients, sodium voiding, and small reactivity effects. In the capacity of Project Engineer, he was responsible for the design, construction, and operation of numerous test assemblies whose construction costs ranged from a few thousand dollars to approximately $\$ 500,000$.

\section{$1966-1968$}

Mr. Springer was Supervisor of the Experimental Physics Unit. This work included responsibilities for the operation of a nuclear reactor critical as sembly.

\section{$\underline{1961-1966}$}

Mr. Springer's work consisted primarily of neutron spectra determinations in nuclear reactors by means of foil activation techniques. He also participated in critical experiment programs which encompassed, among other parts, physics studies relative to various fast power reactor concepts. He was engaged 


\section{T. H. SPRINGER (Continued)}

\section{$1961-1966$ (continued)}

in the investigation, along both analytical and experimental lines, of the Doppler effect in fertile and fissionable materials in various fast neutron systems. In the course of his work, he also participated in the loading and approach-tocritical of various multiregion, fast-thermal nuclear critical as semblies.

\section{$\underline{1955-1961}$}

Mr. Springer was primarily engaged in the design and development of research-reactor, power-reactor and critical-assembly safety devices.

\section{PUBLICATIONS}

'Fast-Spectrum Doppler Measurements," Trans. Am. Nucl.Soc. 6, 242 (1963), Co-author-S. G. Carpenter

"A Measurement of the Doppler Effect in Thorium in a Fast Neutron Energy Spectrum with a Median Fission Energy of 190 key, "Nucl. Sci, Eng. 17, 194-199 (1963), Co-author - S. G. Carpenter

"The Continuous Neutron Flux Monitor Project," NAA-SR-9748, June 1964, Co-author - C. R. F. Smith

"Fast-Spectrum Doppler Measurements" - Part II, A Measurement of a Negative Doppler Effect in U-235 and New Measurements in Th-232 and U-238, "" Nucl. Sci. Eng. 20, 272 (1964), Co-authors - S. G. Carpenter and R. J. Tuttle

"Fast Spectrum Doppler Measurements," Trans. Am. Nucl. Soc. 8, 242 (1965) Co-authors - S. G. Carpenter, L. A. Mountford, and R. J. Tuttle

"Recent Results of Doppler Measurements in Fast Neutron Spectra," Proceedings of the Conference on Safety, Fuels, and Core Design in Large Fast Power Reactors, ANL 7120, October 1965, Argonne National Laboratory, Co-authorsS. G. Carpenter, L. A. Mountford, and R. J. Tuttle

"Doppler Coefficients of Fertile and Refractory Materials," Trans. Am. Nucl. Soc., 8, 454 (1965), Co-authors - S. G. Carpenter, L. A. Mountford, and R. J. Tuttle

"Dependence of the Doppler Coefficient of Reactivity for Heavy Elements on Chemical Form, Surface-to-Mass Ratio, and Neutron Spectrum, "Proceedings of the International Conference on Fast Critical Experiments and Their Analy sis, ANL 7320, October 1966, Argonne National Laboratory, Co-authors, S. G. Carpenter, L. A. Mountford, and R. J. Tuttle

"Variations in the Fast-Spectrum Doppler Coefficients of Th and U-238 as a Function of the Type and Temperature of the Environment," Trans. Am. Nucl. Soc. 11, 241, (1968), Co-author - R. J. Tuttle 
T. H. SPRINGER (Continued)

PUBLICATIONS (continued)

"Measurements of the Temperature Coefficient of Reactivity of U-235, Pu-239, and higher Pu Isotopes," Trans, Am. Nuc1. Soc., 10, 562, (1967), Co-authors R. J. Tuttle and L. A. Mountford

"Surface-to-Mass and Heterogeneity Effects on the Specific Reactivity of Selected Materials in a Fast-Neutron Spectrum" Trans. Am. Nucl. Soc. 9, 504, (1966), Co-authors - S. G. Carpenter, L. A. Mountford, and R. J. Tuttle

"Summary Report, Experimental Physics Characteristics of a Heavy-MetalReflected Fast-Spectrum Critical Assembly," NASA-CR-72820 (AI-71-31) July 197 l, Co-authors - W. H. Heneveld, R. K. Paschall, V. A. Swanson, A. W. Thiele and R. J. Tuttle

"Summary Report No. 2 - Experimental Physics Characteristics of a HeavyMetal Reflected Fast-Spectrum Critical Assembly, "AI-72-33, January 1972, Co-authors - W. J. Heneveld, R. K. Paschall, V. A. Swanson, A. W. Thiele, and R. J. Tuttle

"Reactivity Worths of Boron, Tantalum and Europium in a Fast Reactor Spectrum," Nucl. Sci. Eng. 499, 468-481 (1972)

"Azimuthal Power Distribution in a Thermionic Fuel Element at the Core/BeO Reflector Interface," AI-73-14, January 1973, Co-authors - W. H. Heneveld, V. A. Swanson, R. J. Tuttle 
J. H. VAN OSDOL - Member of Technical Staff, Engineering and Research Department, Atomics International

\section{EDUCATION}

1954-1957 Bradley University; B. S., Mechanical Engineering

1958 -

University of California, Los Angeles; Graduate and Extension

Present work in Nuclear Engineering and Heat Transfer; presently enrolled in the UCLA Graduate School of Management

EXPERIENCE

1961 -Present, Atomics International

Mr. Van Osdol is a system engineer in the Preliminary Engineering Unit. $\mathrm{He}$ is involved in a variety of programs including sodium-helium heat exchangers, coal gasification, geothermal power systems, and multi-megawatt organic Rankine power systems for terrestrial applications. His other recent assignments have been: (1) cognizant engineer on the Clinch River Breeder Reactor sodium-heated steam generator responsible for design, materials, and stress analysis; and (2) cognizant engineer on all engineering activities related to a system designed to test the consequences of a steam tube rupture in a full-scale sodium heated steam generator.

Prior to the se assignments, Mr. Van Osdol was Project Manager for System Engineering for the SNAP Reactor Programs, which covered system engineering, applications engineering, aerospace nuclear safety, heat transfer, fluid flow, and stress analysis. He has also performed numerous studies on nuclear reactor - organic Rankine power systems and various other types of nuclear power systems. Mr. Van Osdol was responsible engineer for systems design analysis, test planning, and evaluation for two SNAP 10A ground tests.

\section{7-1961, McDonnell Douglas}

Mr. Van Osdol performed analytical design of ground support equipment for liquid-propellant missiles and design analysis of thrust chambers and nozzles for solid-propellant missiles. As a member of preliminary design, he participated in design analyses of liquid, solid, and nuclear-powered missiles and space systems.

PATENTS - Electrical Power Generator System (U.S. No. 3,401,064)

PUBLICATIONS

Mr. Van Osdol is author or co-author of numerous reports and papers including the following:

"A 20-Kwe Reactor/Brayton Cycle Power System for Marine Application," AI-73-9P, February 5, 1973

"Nuclear Power System Study," IECEC, San Diego, California, 1972 


\section{J.H. VAN OSDOL (Continued)}

\section{PUBLICATIONS (continued)}

"Unmanned Reactor-Thermoelectric Systems for Applications in the 1970's," Presented at the IECEC, Las Vegas, Nevada, 1970

"Status Report on Small Reactor-Thermoelectric Power Systems for Unmanned Space Applications, "Presented at the IECEC, 1969

"Zirconium Hydride Reactor-Organic Rankine Power Systems," Presented at the IECEC, 1969

"Design Study of SNAP 8 Compact Converter, " NAA-SR-11984, June 30, 1966 (Confidential)

"Low Power Radioisotope Power Supplies for Underwater Use" Presented at the OECON Conference, 1967

"Reactor Power Plants for Lunar Base Applications, " NAA-SR-12374, June 30, 1964 (Confidential)

"Thermal Testing of the SNAP 10A Prototype System, "NAA-SR-9280, July 1964 
L. STABINSKY - Project Development Engineer, Energy Conversion Systems, Atomics International

\section{EDUCATION}

1957 City College of New York; B. S., Mechanical Engineering (with honors)

1960 New York University; M.S., Mechanical Engineering

1970 University of Southern California; Engineer's.Degree, Mechanical Engineering

\section{EXPERIENCE}

1974 -Present, Atomics International

Mr. Stabinsky is currently Project Development Engineer for energy conversion systems. In this capacity he is responsible for meeting the technical objectives of contractual and in-house funded programs related to electric power generation from geothermal and solar energy sources. His responsibilities include supervision and coordination of analytical, design, experimental, and manufacturing functions.

1960-1974, Rocketdyne, a Division of Rockwell International

Mr. Stabinsky was Project Development Engineer on programs related to analytical and experimental envestigations of fluid flow and combustion components and systems. These investigations involved the fields of boundary layers, thermochemistry, heat/mass transfer, and gas-dynamics.

\section{7-1960, Curtiss-Wright Corporation}

Mr. Stabinsky was Assistant Project Engineer working on the development of gas turbines for stationary power plant applications.

\section{2-1957, Combustion Egnineering, Inc.}

While at Combustion Engineering, Mr. Stabinsky was engaged in the design and performance evaluation of industrial boilers and related equipment such as superheaters, economizers, and air-preheaters.

LICENSE - Registered Professional Mechanical Engineer, State of California No. 16,472

SOCIETIES - Tau Beta Pi, Member American Society of Mechanical Engineers

HONORS - AIAA-Minta Martin Award for 1967, North American Aviation WorkStudy Fellowship for 1968-1970

\section{PUBLICATIONS}

Mr. Stabinsky has published numerous reports in the fields of fluid flow, gas dynamics, thermodynamic cycle studies, and combustion. 
A. L. KOHL - Project Manager, Coal Utilization, Atomics International

EDUCATION

$1946-1947$

$1941-1943$

$1954-1955$

University of Southern California, M. S., Chemical Engineering University of So. Calif., B. E. Ch. E. (Summa Cum Laude)

University of California at Los Angeles, Executive Course

EXPERIENCE

1960-Present, Atomics International

Mr. Kohl is currently Project Manager for Coal Gasification Engineering in the Environmental and Utility Systems Department, responsible for the design and construction of a coal gasification demonstration plant. Prior to this assignment he managed a series of contracts for the development of a desalination process and for the generation of power from Imperial Valley geothermal. brine.

In earlier assignments as Group Leader and Project Engineer he was responsible for projects relating to power generation, pollution control, heat transfer, materials, and special components, and directed development programs on fast breeder reactor technology. He was responsible for the design and construction of several test installations and pilot plants.

\section{7-1960, Fluor Corporation, Ltd.}

As Chief Chemical Engineer, Research Division, Mr. Kohl directed research, development, and design activities on chemical processes and engineering products. He invented and directed development of the Fluor Solvent Process for the removal of hydrogen sulfide and carbon dioxide from gas streams. He developed a new cooling tower packing (Polygrid). He was in charge of development work which formed the basis for the Sea Water Desalting Plant constructed near San Diego.

1943-1946, Turco Products, Inc.

Mr. Kohl conducted research on electrolytic surface treatments and conductivity meters. He also served in the Army for 2 years during this period.

AWARDS AND HONORS - Award for Outstanding achievement by local section of AIChE 1966; Technical Achievement Award by Engineers Joint Concil, 1967; listed in American Men of Science, who's Who in The West, and Leaders in American Science

SOCIETIES - American Institute of Chemical Engineers, American Nuclear Society

LICENSES - Registered Chemical Engineer (State of California, No. 915)

PATENTS

Mr. Kohl is inventor or co-inventor of $20 \mathrm{U}$. S. Patents. The se cover a variety of processes and products including the Fluor Solvent gas purification process and Polygrid cooling tower packing. 
A. L. KOHL - (continued)

\section{PUBLICATIONS}

Mr. Kohl co-authored the book Gas Purification, contributed sections to the McGraw-Hill Encyclopedia of Science and Technology, and has written a number of papers on chemical engineering subjects. 


\section{H. L. RECHT - Project Development Engineer, Water Chemical Process Technology, Research and Engineering, Atomics International}

EDUCATION

$1945-1948$

$1948-1954$

1966

1967
Carnegie Institute of Technology; B. S., Chemistry

Cornell University; Ph. D., Physical Chemistry

University of Washington; Technical Seminar; Water Pollution Control in the Chemical Industry

University of California at Los Angeles; Extension Course: Water Resource Quality Control Systems

EXPERIENCE

1962-Present, Atomics International

Dr. Recht is currently charged with responsibility for water technology programs. These include programs on scale and corrosion control in geothermal power and water production, removal of heavy metals and phosphates from wastewater, fundamentals of scale formation in wastewater and desalination plants, and company-sponsored research in corrosion and in water pollution control. Dr. Recht has had technical and administrative responsibility for basic and applied studies in electrochemistry and development of advanced electrochemical power conversion systems. These have included the PERC sodiumair system and the TRAC thermally regenerative cell concepts.

1961-1962, Astropower, Inc.

Dr. Recht had technical and administrative responsibility for fuel cell development, as Head of the Electrochemistry Group.

\section{9-1961, Atomics International}

Dr. Recht conducted research in graphite-sodium vapor interaction and development of low temperature fuel cells. He provided significant contributions to fuel cell technology, particularly in the area of electrode development.

1954-1959, Consolidation Coal Company

Dr. Recht was the research chemist on the pioneering effort in this country for the development of high temperature fuel cells, which included research on porous magnesia ceramics and ceramic lithiated nickel oxide air electrodes.

SOCIETIES: American Chemical Society; American Physical Society; Electrochemical Society; Fellow, American Association for the Advancement of Science; Pi Mu Epsilon; Phi Kappa Phi; Sigma Xi; American Men of Science; Califomia Water Pollution Control Association; American Water Works Association 


\section{H. L. RECHT (Continued)}

\section{$\underline{\text { PATENTS }}$}

U. S. Patent 2,901,254, A Method for Regulation $\mathrm{CO}_{2}$ Pressure in a Fuel Cell (with E. Gorin)

U. S. Patent 2,914,596, A Ceramic Nickel-Oxide Electrode Containing Lithium (with E. Gorin)

U. S. Patent 3, 419, 435, Energy Conversion Process and Apparatus (with D. E. McKenzie)

U. S. Patent 3,419,436, Porous Matrix for Galvanic Cell (with M. L. Iverson)

U.S. Patent 3,736,255, Water Decolorization (with M. Ghassemi and E. V. Kleber)

\section{PUBLICATIONS}

\section{Research Papers}

"Fuel Cells," E. Gorin and H. L. Recht, Proceedings of the Tenth Annual

Battery Research-Development Conference, Fort Monmouth, N. J. (1956)

"High-Temperature Fuel Cells," H. L. Recht, Proceedings of the Twelfth Annual Battery Research-Development Conference, Fort Monmouth, N. J. (1958)

"Fuel Cells," E. Gorin and H. L. Recht, Mechanical Engineering, Vol. 81, No. 3 (1959)

"Fuel Cells," E. Gorin and H. L. Recht, Chemical Engineering Progress, Vol. 55, No. 8 (1959)

"Fuel Cells," H. L. Recht, Encyclopedia of Chemical Technology, Second Supplement, Interscience Publishing Co. (1960)

"The Nature of the Electrode Processes in Fuel Gas Cells," E. Gorin and H. L. Recht, Fuel Cells, Reinhold Publishing Co. (1960)

"High Temperature Fuel Cells, E. Gorin and H. L. Recht, Fuel Cells, edited by W. Mitchell, Jr., Academic Press (1963)

"The Interaction of Graphite with Sodium Vapor," H. L. Recht, G. Wolten, and D. Gilmartin, J. Inorg. Nucl. Chem. 23, 275 (1961)

"Activity of Sodium in Sodium Amalgams from E. M. F. Measurements," M. L. Iverson and H. L. Recht, J. Chem. and Eng. Data 12, 164 (1967)

"Regenerative Electrochemical Systems," co-author of three chapters, edited by C. E. Crouthamel and H. L. Recht, Advances in Chemistry Series, No. 64, A. C. S., 1967

"The Atomic International Sodium - Air Cell, "L. A. Heredy, H. L. Recht, and D. E. McKenzie, in "Power System for Electric Vehicles," U.S. Public Health Service Publication No. 999-AP-37 (1967)

"Precipitation of Phosphates From Water and Wastewater Using Lanthanum Salts,"H. L. Recht, M. Ghassemi, and E. V. Kleber, Proceedings, 5th International Water Pollution Research Conference, Paper I-17, Pergamon Press (1971) 
H. L. RECHT (Continued)

\section{$\underline{\text { Reports }}$}

Scale Formation

H. L. Recht; "A Tracer Study of Prescale Deposition of Scale Forming Compounds on Controlled Surfaces," Office of Saline Water. R \& D Progress Report No. 632, May, 1971.

H. L. Recht; "Evaluation of Scale Deposition in the Porteous Process," AI$71-6$, Report to Envirotech Corp., Jan., 1971.

H. L. Recht, J. R. Birk, \& L. R. McCoy "Porteous Process Studies on Scale Removal, "AI Report to Envirotech Corp., Sept, 1971.

L. R. McCoy, L. F. Grantham, \& H. L. Recht, "Prevention of Scale Deposits in the Porteous Process," AI Report to Envirotech Corp., May, 1972.

Water Instrumentation

L. R. McCoy \& H. L. Recht "Cation Responsive Electrode (Salinity Meter)," AI Report to Envirotech Corp., August, 1971.

L. R. McCoy \& H. L. Recht "Phosphate Ion Measurement, "AI Report to Envirotech Corp., August, 1971.

Phosphate Removal

H. L. Recht \& M. Ghassemi, "Phosphate Removal From Wastewater Using A1 (III) and Iron (III) Salts, U.S. D. I., FWQA Report 17010 EKI 04/70.

H. L. Recht \& M. Ghassemi, "Phosphate Removal From Wastewater Using Lanthanum Precipitation," U.S.D.I., FWQA, Report 17010 EFX 04/70

M. Ghassemi \& H. L. Recht, "Phosphate Precipitation With Ferrous Iron, "', U.S.E. P. A. , Report 17010 EKI 09/71

\section{Corrosion}

H. L. Recht \& W. H. Friske, "Materials Selection For the BSP Heat Treatment Processing of Saline Sludges, "AI-73-5, Report to Envirotech Corp., Jan., 1973.

Heavy Metal Removal From Water

H. L. Recht, L. R. McCoy, R. D. Rennick, "Laboratory Demonstration of the Atomics International Process for Removal of Heavy Metals From Water, "AI-73-13 Final Report to the California State Water Resources Control Board, Oct., 1972. 
CORNELIUS E. BERTHOLD - Senior Research Engineer, Hazen Research, Inc.

\section{Education}

B.S. Chemistry, Engineering minor, 1953, University of California at Los Angeles.

\section{Special Fields}

Hydrometallurgy of alkali metal and manganese ores. Titanium dioxide pigment technology. Chlorination processing of ores. Processing of saline minerals and brines. Solar evaporation technology.

\section{$\underline{\text { Experience }}$}

Hazen Research, Inc., November, 1970 to present, Senior Research Engineer.

American Potash \& Chemical Corp., 1953 to 1970. Subsidiary of Kerr-McGee Corp. Manager, Process Engineering from 1967 to 1970. Responsible for process development and economic evaluations on projects related to saline brine processing at Seurles Lake, California, including solar evaporation technology, leaching, crystallization and other unit operations. Plant expansion design for chloride process titanium dioxide pigments plant at Hamilton, Mississippi.

Project Manager, Central Engineering Department, 1964 to 1967 . As project manager and assistant project manager was involved with design, equipment specifications, materials selection and start-up of $\$ 20,000,000$ titanium dioxide pigment plant and subsequent additions to the plant.

Section Head, Research Department, 1962 to 1964. Pilot plant operations and plant design of titanium dioxide pigments plant in conjunction with Laporte Titanium, Stallingborough, England.

Research Engineer and Senior Research Engineer, 1954 to 1962. Laboratory and pilot plant studies on recovery of alkali metal compounds and manganese compounds from their ores.

\section{Professional Affiliations}

American Institute of Mining, Metallurgical and Petroleum Engineers American Chemical Society 
CORNELIUS E. BERTHOLD (Continued)

Publications and Patents

U.S. 2,959,477 Process for Recovery of Manganese from Rhodonite Ores

U.S. 3,112,169 Recovery of Cesium Values from Pollucite Ore

U.S. 3,112,193 Recovery of Manganese Compounds from Rhodonite

U.S. 3,207,598 Recovery of Cesium Values from Pollucite

U.S. 3,207,571 Process for Recovery of Cesium Carbonate and Cesium Salts from Pollucite Ore 
JAMES E. REYNOLDS - Senior Research Engineer, Hazen Research, Inc.

\section{Education}

B.S. Chemical Engineering, 1952, University of Wisconsin M.S. Chemical Engineering, 1954, University of Wisconsin

\section{Special Fields}

Electrochemistry, crystallization, air pollution control, production management

\section{Experience}

Hazen Research, Inc., March 1973 to present, Senior Research Engineer.

Kerr McGee Corporation, Oklahoma City, 2-1/2 years. Manager of Electrochemical Research and Process Development. Responsible for research programs at two hydrometallurgical plants. In charge of air pollution activities in six fertilizer granulation-super phosphate-HFS acid plants.

American Potash and Chemical Corporation, Henderson, Nevada, 12 years. Manager of Plant Technical Services. Electrolytic and extractive metallurgical processes producing chlorates, perchlorates, and electrolytic manganese dioxide.

Manager of manganese dioxide plant.

Senior Research Engineer, specializing in crystallization, electrolytic cell design, high energy boron fuel development and production, general plant process troubleshooting.

Rocketdyne (North American Aviation), Canoga Park, California, 2 years. Design Engineer, thrust chambers, fuel injectors, gas generators.

Bjorksten Research Labs, Madison, Wisconsin, 2 years. Bench chemist, development and application of polymeric materials.

R.A. Stern, Naval Architect, Sturgeon Bay, Wisconsin, l year. Ship design, piping layout.

\section{Professional Affiliations}

American Institute of Chemical Engineers

Technical Association of the Pulp and Paper Industry 
JAMES E. REYNOLDS (Continued)

\section{Publications and Patents}

"The Manufacture of Perchlorates," Chemical Engineering Progress, Vol 57, 11, November, 1961

Ibid, Vol 57, 12, December, 1961

Hybrid Bipolar Electrode for Electrolysis of Chlorine, Chlorates and Other Compounds.

Electrolytic Purification of Magnesium Perchlorate

Chlorine Dioxide Process

Rapid Alloying Manganese Metal 
BYRON W. BERTHELOT - Engineering Supervisor, Geothermal, Phillips Petroleum Company

ADDRESS:

TELEPHONE:

DATE AND PLACE

OF BIRTH:
2765 Montego Cove, Del Mar, California 92014

(714) 755-0131 (Office)

(714) 755-2852 (Home)

April 26, 1924, Denver, Colorado

\section{EDUCATION}

Civilian Bachelor of Science in Petroleum Engineering and Bachelor of Science in Mechanical Engineering with Diploma of Distinguished Scholarship from the Agricultural and Mechanical College of Texas, College Station, Texas, on May 10, 1948. Tau Beta Pi, December 3, 1948.

Military Basic Officer Course: Aberdeen Proving Ground, Maryland, June 1944.

Associate Ordnance Career Course: APG, Maryland, 1960. U.S. Army Command and General Staff College, Ft. Leavenworth, Kansas, 1967.

\section{EXPERIENCE:}

U.S. Army Enlisted Private unassigned December 7, 1942. Active Duty March 1943 to September 1946. Private trainee; Corporal Artillery Repair Instructor; 2nd Lieutenant Platoon Leader; lst Lieutenant Commanding Officer 8 lst Ordnance Tank Maintenance Company, ASCOM Korea. Final active reserve assignment, 1963 to 1967, Headquarters Commandant, 95th Division (Tng.) - Detailed General Staff. Retired from U. S. Army Reserve - Lt. Colonel, September 1968.

Phillips Petroleum Company

1973 to Present, Del Mar, California. Engineering Supervisor Geothermal. Assessment of the geothermal natural resource as a potential significant source of income for Phillips Petroleum Company. By direct involvement in exploration, development and exploitation of geothermal resources the relative profitability and social contribution potential will be determined. 
BYRON W. BERTHELOT (Continued)

EXPERIENCE (Continued)

1968 to 1973, Oklahoma City, Oklahoma. Senior Reservoir Engineer. Administration and management of unitized jointinterest secondary recovery oil properties. Chairman of the Operating Committee, Southwest Antioch Gibson Sand Unit, Bradley Springer Sand " $C$ " Unit, Panther Creek Gibson Unit, Panther Creek Hart Unit and Doyle Field Unit. Represents Company as member of numerous working interest owner groups for partner-operated properties directing operations of functioning units and negotiating equitable participation for Company in proposed projects.

1963 to 1968, Oklahoma City, Oklahoma. Regional Supervising Reservoir Engineer. Planning, organizing, directing and controlling reservoir work by supervision of assistant and functional direction of district reservoir engineers. Handling special problems in regulatory matters, unitization, reserves, evaluations, property acquisitions, development, producing operations. Conducting technical employee training and continuing education programs.

1955 to 1963, Denver, Colorado; Midland, Texas; and Oklahoma City, Oklahoma. Division Reservoir Engineer. Oil and Gas Development and Producing Operations, Unitization and Secondary Recovery, Reserves, Special Studies, Hearing and Lawsuit Direction in Proration and Regulatory Actions. Expert Witness.

1952 to 1955, Bartlesville, Oklahoma. Assistant Area Petroleum Engineer. Property Evaluation, Waterflood Design and Operation, Oil and Gas Reserves, Witness Oklahoma Corporation Commission and Texas Railroad Commission Hearings.

1949 to 1952, Borger, Texas. District Engineer. Property Studies, Reservoir Analysis, Well Completions and Workovers, Pressure Maintenance Projects.

1948 to 1949, Eureka, Kansas, and Odessa, Texas. Field Engineer training 52 -week program. 